CIHM

Microfiche

Series

(Monographs)
ICMH

Collection de microfiches (monographies)
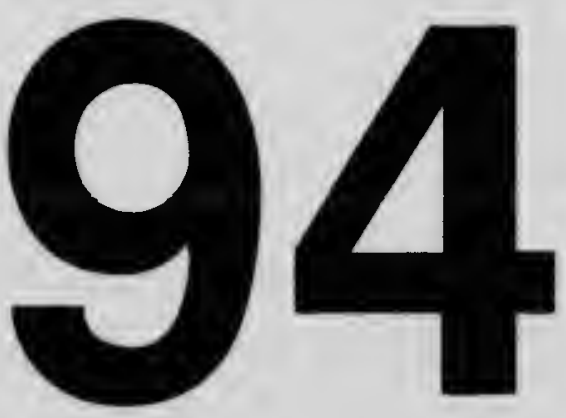
The Institute has attemp ind to obtain the best oripinal copy available for filming. Features of this copy which moy be bibliogreghically unique, which mey chter any of the imeses in the reproduction, or which mey signifieantly chanes the usuel mothod of filming, ene checked bolow.

\section{Coloured coverd}

Couverture do couleus

Covers demeged

Couverture endommente

Covere restored end/or Ieminased/

Couverture restauris atou pallicalls

Cower tith missing/

Le titre de couverture manqus

Coloured mepal

Cornes chosrephiques en couleur

Coloured ink (i.a. other then blue or black)/

Encese de coulaur (i.s. autre que bleus ou noire)

Coloured plates and/or illustrations/

Planches et/ou illustrations en coulaur

Bound with other material/

Ralis avec d'autres documents

Tight binding may couse shadows or distortion along interior marein/

Le raliure serribe peut causer do l'ombre ou de la distorsion la long de la mares intérieure

Blank leaves addod during restoration moy eppear within the text. Whenever possible, these haw been omireved from filmingl

II se peut que certaines paes blenches ajoutdes lors doune restauration apparaisent dans la taxte. mais, lorsque colo btait possibla. ces peses n'ont pes itte filmber.
L'Institut a mierofilm le mailleur exemplaire qu'il lui a its possible de es procures. Les ditails de cet axcmplaire qui sont peut-itre uniques du point do vue biblioercephique, qui peuvent modifier uns imess reproduits, ou qui peuvent exiser une modfieation dans la mithode normale de filmas sont indiqus ei-doseous.

Coloured peesel

Pereses de couleur

Paese damened/

Payes endommenies

Paces restored and/or laminuted/

Pages restaurios ot/ou pelliculies

Penes discoloured, stained or foxed/

Peeses discolories, tachaties ou piquies

Poces dotechnd/

Paces dicaenties

Showthrough/

Trensparence

Quality of print varias/

Qualité incale do l'impression

Continuous papination/

Pagination continus

Includes index(es)/

Comprend un (des) index

Title on hesder eaken from:/

Le titre do l'en-tste provient:

Titla pare of isaud

Page de tirre de la livraison

Caption of issud

Titre de dipan de la livraison

Masthead/

Ginerique (piriodiques) de la livraison

Additiond comments:/

Commentaires supplímentrires:

This item is filmed at the reduction ratio eheeked below/ Ce document est films ou taux de riduetion indiqué ci-dessous.

$10 x$ $14 x$

$18 x$ $2 x$ $26 x$ $30 x$

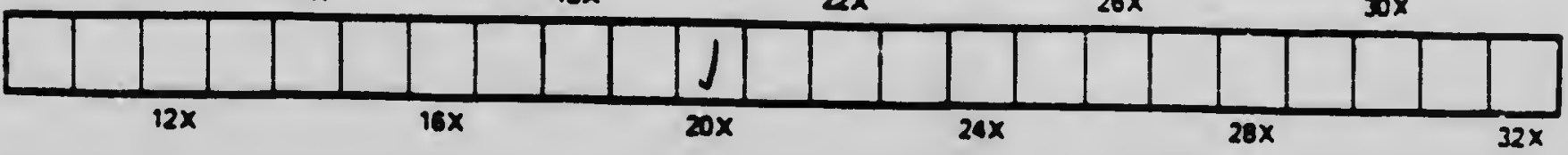


The copy flimed here hes been reproduced thenks to the generosity of:

\section{Natlonai Librery of Conade}

The Imeges eppearlne here ere the best quality possible considering wis condition and legibility of the original copy sud in keoplng with the filiming contract specifloctions.

Original coples In printed paper covers are filmed boginning with the front cover end ending on the last page with a printed or lilustroted impression, or the back cover when eppropriate. All other original coples ere fllmed beginning on the first pege with a printed or llluatreted Impression, end ending on the lest page with a printed or lliustrated impreasion.

The leot recarded frome on eech mlcroflche shail contain the symbol $\longrightarrow$ Imoening "CONTINUED"), or the symbol V (meaning "END"). whichover epplles.

Meps, plates, chorts, etc., may be flimed at different reduction ratlos. Those too large to be entirely inciuded in one exposure are filmed boginning in the upper loft hond corner, laft to right and top to bottom, as many frames es required. The following diegrams lliustrate the mothod:
L'exemplaire fllme fut reproduit orfes $\mathrm{I}$ gonsroslte de:

Bibilothdque notlonale du Canada

Les Imeges suiventes ont ste reproduites ovec is plus grend soin, compte tenu de le condition at de le nottoté de l'exempibire filims. et en conformité evec les conditions du contret de flimage.

Les exemplaires orlginoux dont la couverture en popler eot Imprimbe sont flimbe on commencent par le premier piat ot en torminant soit par le dernibre poge qui comporte une emprelnte d'impression ou d'lliustrotion, solt por le second plot, evion lo cas. Tous les outres exemplaires orlginaux sont fllmes en commencant par le promilere page qui comporte une emprelnte d'Impression ou d'tllustration et en torminant par la dernlore poge qui comporte une telle emprointe.

Un des oymboles sulvents epperaftre sur io dernibre Imoge de cheque microfiche, selon ie ces: is oymbole $\rightarrow$ signifie "A SUIVAE", ie symbole $\nabla$ signifle "FIN".

Les cartes, pienches, tabieaux, etc., peuvent être flimbs des taux de réduction différonts.

Lorsque is document est trop grend pour atre reprodult on un soul clichs. II eot flims o partir de lengie supérieur geuche, de geuche o drolte. et de haut en bas, en prenent ie nombre d'imeges núcessaire. Les diagremmes sulvont Illustrent is mothode.
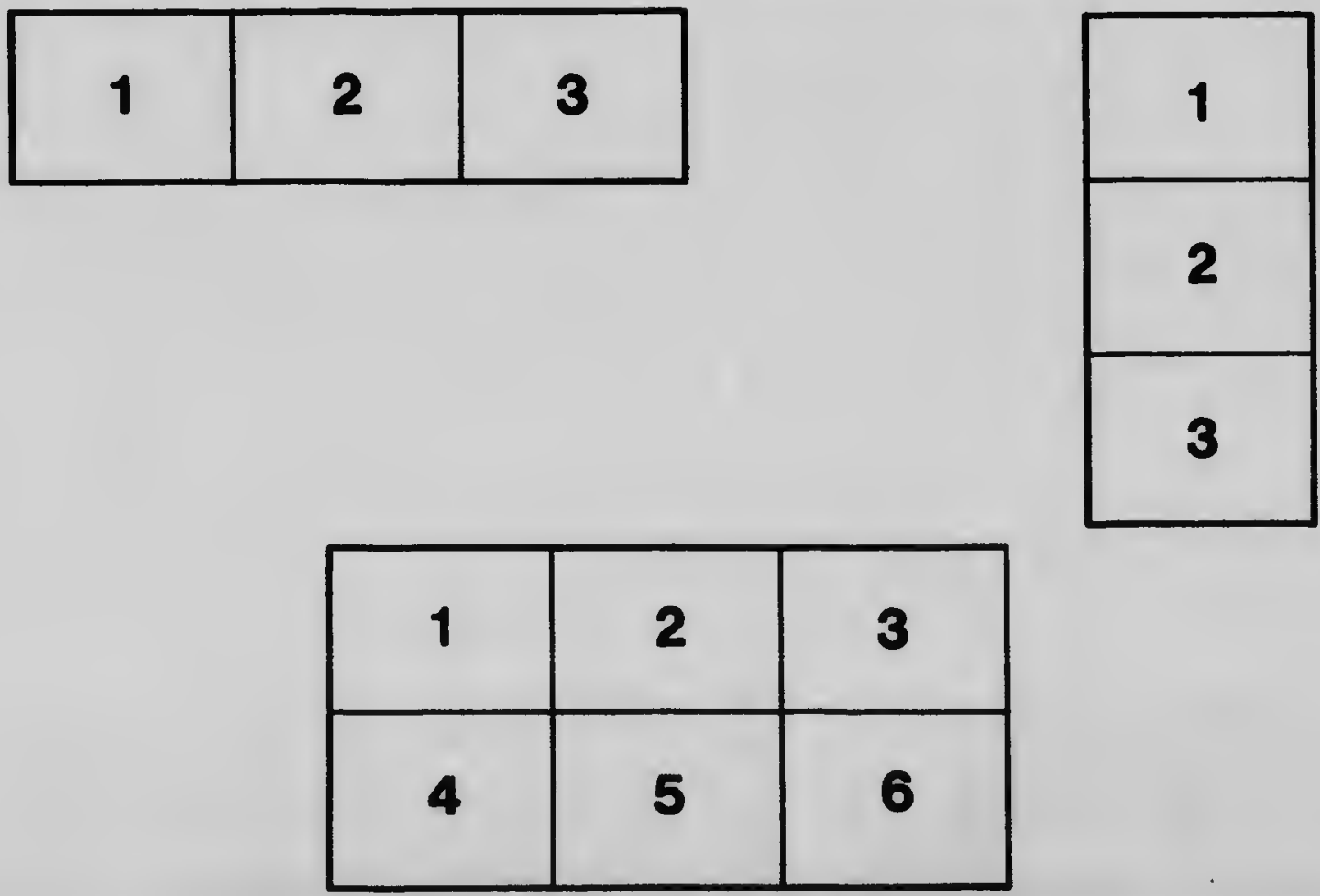


\section{MUCROCON RESOUTION TEST CHART}

(ANSI and ISO TEST CHART No. 2)
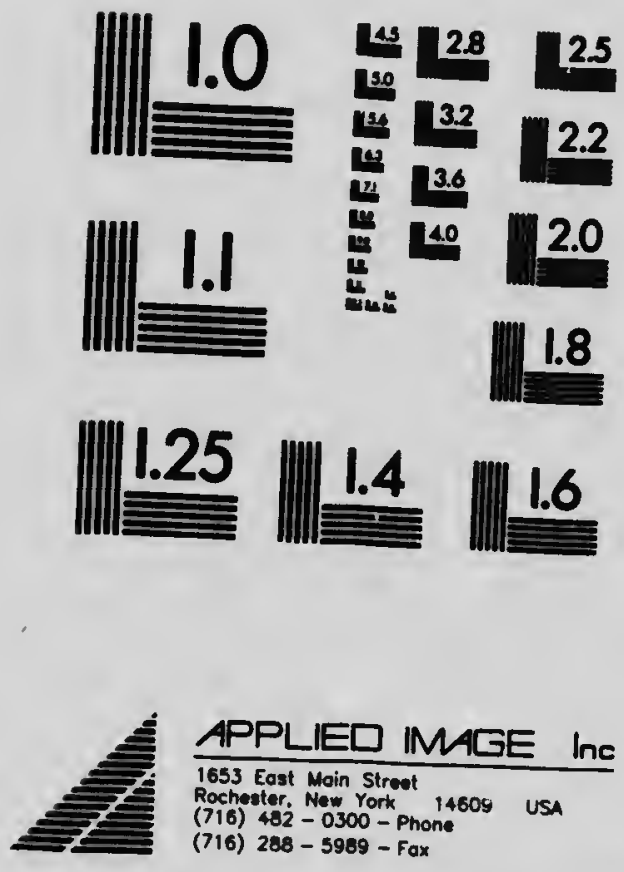
15780

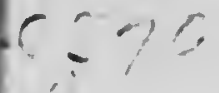

\section{ALLEA SAF-}

4

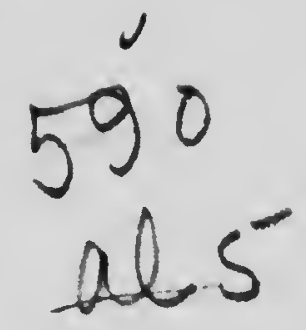

TH:S PROPERT : OF $\triangle C$.A RBOSRO FL'BLIC LIBRARY.

IN NATURE'S WORKSHOP 


\section{By the same Author.}

\section{FLASHLIGHTS ON NATURE. With}

I jo Illustrations lyy l'rederick Enoch. Crown

8vo, cloth extra, 6s.

if The book will make an aclmirable gin for any persoll who cares for country life, and even for the town dweller it will be useful, for he can see many of the subjects dealt with in the parks and open spaces."-l.ancel.

THE STORY OF THE PLANTS. With 49 Illustrntions. Cloth, 18.

"The whole of the book is excellent, but special praise is due to his exposition of the relations existing between plants and insects. Many chupters of th: story he tells must prove to the unitiated as exciting as a romance." -Aberdeen fire Press.

LONDON: GEORGE NEWNES, LIMITED. 


\title{
In Nature's Workshop
}

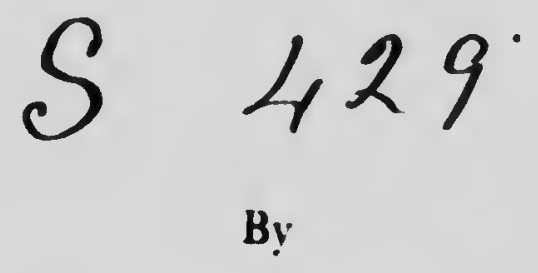

\author{
Grant Allen
}

Author of . Flashlights on Nature"

". "The Story of the Hante," ete.

With 100 Illustrations by

Frederick Enock

\author{
Toronto \\ William Briggs \\ I 901
}


갠:

$A \div 5$

1.2. 


\section{CONTENTS AND ILLUSTRATIONS}

SEXTONS AND SCAVENGERS . PAGE GROUPS OF SEXTON BEETLES THE SEXTONS AT WORK THE GRUBS UNDERTROUND THE GRUBS IN THEIR COCOONS TURNING $\cdot{ }^{-} \cdot{ }^{-}$II SACRED SCARABS ROLLIYG THEIR FOODOBAINTO BEETLES I3 PR.AITIVE GOLFAN EGYPTIAN SACRED SCARAB

\section{FALSE PRETENCES}

A BATTLE ROYAL: SCOKPION ש SPITER $\cdot 29$ THE DEVIL'S COACH-HORSE IN HOURS OF EASE $\cdot \cdot 3 I$ THE DEVIL'S COACH-HORSE SAMIILING A CATERHILIAR • 33 THE DEVIL'S COACH-HORSE I'RETENDS TO BE ACOLAR • 34 CATERPII.I.AR TRYING TO I.OOK ALARAING FULI.-GROIVN CATERPILLAK SIMILARI.Y OCCUPIED • • 43 CATERPILLAR PREPARING FOR ACTION THE SAME CATERPILLAR TERRIFYING AN ENEMY • • 46 CATERPILLARS OF TIIE I.OBSTER NOTI GRASS-SI'IDER IN AMBUSII FOR FLIES $\cdot \cdot \cdot \cdot 50$ GRASS OF PARNASSUS . A SINGI.E PETAL.

PLANTS THAT GO TO SLEEP . . . . . 60 BRANCH OF MIMOSA, TIF: I.EAF AIIAKE . . . . 64

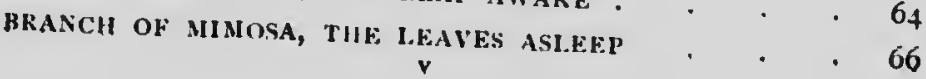




\section{CONTENTS AND IlLuSTRATIONS}

WOOD-SORREL, TUE WLWER ANII IEAVES DOTI AWAKE PAG H.OWER AND I.EAVES BOTII AWAKE 68 HE FLOWER AND I.KAVES BOTII ASI.EEP 69 PURPLE CROCUS, OPEN IN SUNSHINE • • • • 73 THE CROCUS CLOSES TO PROTKCT ITS POI.LEN . • • 75 WILD GERANIUM, LAYING ITSEI.F OUT TO ATTRACT INSECTS WILD GERANIUM AT NIGIIT $\cdot{ }^{\circ} \cdot{ }^{\circ} \cdot 76$ CARLINE TIISTIE, ITS BRACTS OPEN ${ }^{\circ} \cdot{ }^{\circ} \cdot \cdot 77$ $\cdot \quad \cdot \quad \cdot 78$ CATCHFLY, SLEEPING BY DAY . . 82 CATCHFLY, SLEEPING BY DAY • . . . . . 85 CATCHFLY, OPENIN(; ITS WHITE PETAIS AT NIGHT . 86

MASQUERÁDES AND DISGUISES . . . . . . 88 TIIE SEA-HORSE, UNDISGUISED . . . . . . . 89 A PAIR OF SEA-HORSES, MOORED TO A FUCUS..$\quad \cdot 90$ AUSTRALIAN SEA-HORSE, DISGUISED AS SEAWEED • • 92 KALLIMA BUTTERFLY, DISILAYING ITSELF WHILE FLYING 94 THE SAME KALLIMA, SETTLED ON A TREE • • • 95 LOWER FIGURE, THE COMMON HORNET : UPPER FIGURE,

TIIE MOTH IVHICH PERSONATES IT • • • • 99 HORNET AND HORNET CLEAR.WING MOTH . . . 104 LOWER FIGURE, BUMBLE-HEE: UPPER FIGURL, FLY WHICII IMITATES IT THE REAI. BEE AND THE EALEE ONE $\cdot$ • 105 $\cdot \quad \cdot \quad 106$ CATERPILLAR OF THE SWALLOW-TAIL MOTH . . . II2 CATERPILLAR OF THE THOKN MOTH . . . . 113 COMMON STICK-INSECT . . . . . . . . II4

SOME STRANGE NURSFRIES . . . . . . 116 STICKLEBACK'S NEST • • • . . • • • 123 THE MOTHER LAYING THE FGgS . . . . . 124 THE FATIIER AIRINI; THE EGGS . . . . . 126 MOTHER TURE-MOUTH CARRYING HER EGGS IN A POUCH Ijo THE POUCH WITH EGGS INSIDE IT . . . . • I I I 


\section{CONTENTS AND ILLUSTRATIONS}

FATHRR PIPE-FISH CARRYING HIS YOUNG IN PACR SURINAM TOAD, CARKYING HER FAMILY • $\quad \cdot \quad \cdot \quad \cdot \quad \cdot 133$

ANIMAL ANI) VEGETABLE HEDGEHOGS • . $\quad 142$ IIEDGEIJOGS, ROILLED AND INROI.I.EI) . . . . I43 A SEA IIEDGEIICG, THE GLOHE-FISII, SWIMMING FREILY. I 50 THE (ILOBE-FISII, INFLATED, WHEN DANGER THREATENS I5I "WHO'S AFRAID? LET 'KM ALI. COME!" • • • 152 A VEGETABI.F heDGEHOG • • • • • • • 156 TOP PART OF TIE SAME, SHOWING THE ROWS OF FIXED BAYONETS

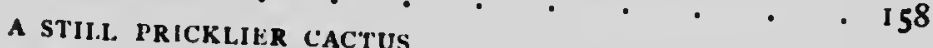
A P'RICKI.Y LIZARD A PLANT OF THE SAME TYPF: BRANCH OF GORSE A FISH, DEFENDED ON BACK ONLY • $\cdot \cdot \cdot \cdot 164$ A SPINY THISTLE THE PRICKLY CRAB A SEA-URCHIN A PRICKLY BEeTLE A PRICKLY CATERPIILAR

THE DAY OF THE CANKER-WOKM

$+\quad 176$

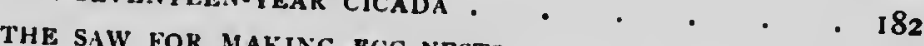
SECTION OF THE SAIV, SIIOIVING OW THE PARTS FIT NESTS AND EGGS IN TWW TWITS OF CHESTNUT $\cdot . \quad . \quad 184$ THE GALLERIES FOR THE PUPAD EIGHTEEN MONTHS . I86 THE PUPA COMES OUT AND THE CICADA COMES OUT OR ${ }^{\circ} \cdot{ }^{-} \cdot{ }^{\circ},{ }^{\circ} 88$ HODY FREE! IS9 


\section{CONTENTS AND ILLUSTRATIONS}

WINGS AND LEGS ALI, OUT! PAGE HOLDING ON BY HEY . $\quad 191$ PLIMMING HER WINGS 192 WINGS FULIY EXPANDED LAYING EGGS CARRIED OFF BY AN ENEMIY ${ }^{\circ} \cdot{ }^{\circ} \cdot{ }^{\circ} 195$ THE ENEMY'S LARVA $\cdot{ }^{\circ} \cdot 190^{\circ}$ THE ROBBERS' OF THE ENEMY'S BURROWS 198 LIFE-HISTORY OF THE ARMY-WORM . . . . . 203

\section{ARMOUR-PLATED ANIMALS . . . . . . 207}

TILE-SHAेPED PLATE-ARMOUR : TIE PANGOLIN . . 207 THE TREE-IIAUNTING PANGOI.IN • $\cdot 210$ SOLID CUIKASSR.S : THE TIIREE-BANDED ARMADILLO $\cdot 215$ AN ENEMY THREATENS: THE ARMAD THE "ARMADILLO" WOOD-LOUSE • 219 A SOUTH AFRICAN TORTOISE WITH DISTINCT • $\cdot$ - 22 I A SOUTH AFRICAN TORTOISH ALES ALMOST ORLITERATED $\quad 227$ THF SPINY LOBSTEK'S TAIL A KNIGHT'S PLATE-ARMOUR ${ }^{\circ} \cdot{ }^{\circ} \cdot 233$ A JOINTED AND ARMOURED MOLLUSC, THE CHITON $\cdot 234$ A MAILED WATER-BEETLE A MAILED WATER-BEETLE . • • • • • 239 


\section{IN NATURE'S WORKSHOP

SEXTONS AND SCAVENGERS

I

$\mathrm{N}$ a certain sense, all animated nature is but a single vast co-operative society. I am no foolish optimist : I will admit, indeed, that the members of the society so composed often display to one another the most unfriendly and unfraternal spirit. The hawks, for instance, show a distinct want of true brotherly love towards the larks or the tomtits : and the mice and lizards find the ou cats by no means owls and the society is hardly clubbable. The co-operative family. Still, in what one could call a happy the poet that "Nature of the fact insisted upon by no preacher can heal " it one with rapine-a harm a certain rough balan is none the less true that adjustment of part to accommodation or ment of animal and part, occurs in every departto think, it could hegetable life. When we come only exist if they contain be otherwise. Things can tions necessary to contain in themselves the condior plant perishes existence. An unadapted animal 1. plant perishes instantly. Spiders could not live 
in an island which contained no flies; kingfishers necessarily presuppose fish; and silkworms imply the presence of mulberry leaves. You cannot have vultures wild in a country where there are no dead animals lying about loose; nor can you keep bees except where there are honey-bearing flowers. Dutch clover depends for its very existence upon a few insects which fertilise it and set its seeds. The draining of the fens killed out a dozen species of English plants and animals; the inclosure of the prairies deprived the buffaloes of their chance of pasture! In this sense, all nature hangs together as it were; each species fills some place in the great mosaic which cannot be altered without considerable disturbance of adjacent pieces. Destroy the rabbits in a given area, and you have nothing left for the weasels to feed upon.

Sometimes, too, apparently unimportant or unnoticed creatures perform in the aggregate some valuable work for the rest of the plant and animal community, which little suspects its real indebtedness to them. Darwin showed long ago that the humble and despised earthworm was really answerable for the greater part of that rich layer of vegetable mould or soil which covers the bare rocks; it deposits the material in which all our plants root and from which they derive a large element of their sustenance. Kill out the earthworms over the whole of our earth, and you would reduce a vast proportion of it to the condition of a desert. For the worms pull down green leaves into their neat little burrows; and the refuse of 


\section{Sextons and Scavengers}

these leaves, continually renewed from season to season by the industrious small workmen, forms by far the greater share of that dark layer of vegetable mould which is the chief source of the fertility in plains and lowlands. Sandy upland spots, where worms are few, form little or no soil, and will only support a poor moorland growth of gorse and heather. You must have plenty of worms if you want to grow corn or turnips.

But there are other unconsidered creatures besides these, creatures which perform for us functions almost as useful and important as those of the earthworms; and I propose to devote a few pages here to one such group, the sanitary commissioners of the insect world, as I will venture to call themthe vast body of minor sextons and six-legged scavengers. Has it ever struck you that as you walk abroad through the rich green meadows and pastures of England, you almost never come across a dead and decaying animal? I do not mean large animals like horses and donkeys: those do sometimes occur unburied, giving us bold and unpleasant advertisement of their near presence. But just consider that the fields through which you stroll are a perfect warren of moles and shrews and fieldmice and water-voles and frogs and lizards and rabbits and weasels, to say nothing of smaller fry; and then think how seldom on your morning rounds in the country you come across a single dead bird or rat or adder, a departed toad, or a late lamented leveret. The ground about you teems with life: but where are its cemeteries? Squirrels and dor- 
mice are dying in every copse : but what becomes of their bodies? Who ever saiv a dead bat? Who knows the tomb of the deceased hedgehogs?

Of course a great many of the smaller animals die a violent death, and find their living grave in the maw of their devourers-one must admit that explanation as covering a very large number of cases. Thirty field-mice have been disinterred from the stomach of a single buzzard when it was shot in the act of digesting after a good dinner; and owls and snakes are answerable for the fate of no small proportion of our minuter wild animals. In other cbuntries, too, vultures and jackals devour most of the carrion as it lies; while even in England we have a few dead-meat-eaters, such as the carrion-crow, the rat, and the shrike. But for the most part our rural English public scavengers are smaller and less conspicuous creatures. Foremost among them in number and utility we may reckon the various kinds of burying beetle.

If you do find the body of a mouse or shrew lying unburied in England, it occurs almost always on a path or high-road. Now this fact is in itself significant; for the high-road is practically a manmade desert, so hardened and steam-rollered, so pounded and wheel-ridden, that no plant can grow on it; so exposed that small animals will only scurry across it for dear life in fear and trembling ; and so difficult to dig into that no burrowing creature can hope to worm his toilsome way through it. Hence the animals that die on the road are almost never buried; while those that die 
in the field or copse are either eaten at once by larger beasts, or else decently interred within a few hours by the sexton beetles and other established scavengers. Indeed, a common superstition exists among country folk that one of the small longnosed, insect-eating animals known as shrews cannot so much as cross a road without being killed instantly. A human track is supposed to be fatal to them. The superstition has arisen in this way : shrews die of cold and hunger in great numbers at the approach of winter. A certain proportion of them perish thus in the open fields; these, however, are immediately buried by the proper authorities, the sexton beetles. But a few happen to die as they are crossing a road or path; these lie where they fell, because the sextons cannot there pierce the hard ground, and seldom even dare venture on the road to carry. them off to softer spots for burial. The rustic sees dead shrews in the road, and none on the open ground: so he hastily concludes in his easy-going way that to cross a human path is sudden death to shrews, who are always supposed for other reasons to be witch-like and uncanny animals. If the road leads to a church, a fatal stroke is specially certain : for the shrews, like all witch-creatures, hate Christianity.

I need hardly say, however, that the burying beetles do not perform their strange funereal office out of pure benevolence, without hope of reward. Like human sextons and undertakers, they adopt their lugubrious calling for the sake of gain : they expect to be paid for their sanitary services. The 
payment is taken in two forms : one, immediate, as food for themselves; the other, deferred, as board and lodging for their children.

Our illustration No. I introduces us to a typical

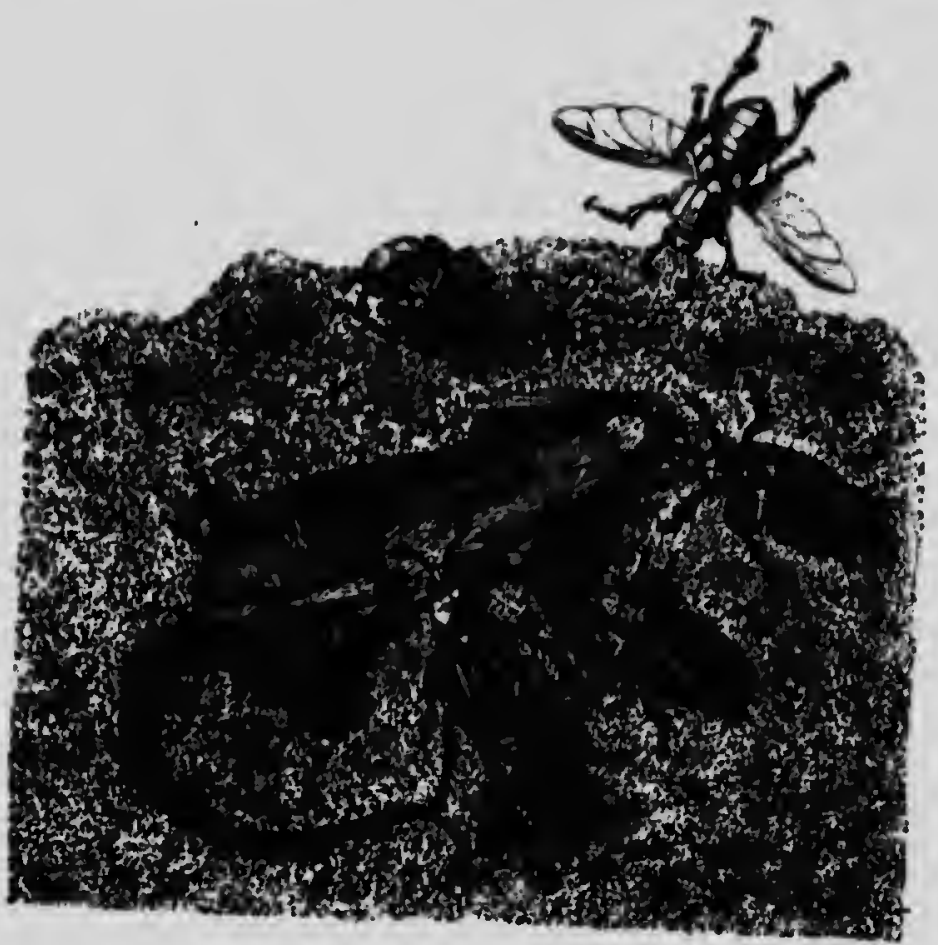

No. 1.-GROUPS OF MISCELLANEOUS SEXTON BEETLES, DISCOVERING A DEAD FIELD-MOUSF.

miscellaneous group of these insect scavengers, occupied in appropriating a very fine and desirable carcass on which they have just lighted. A tield. mouse, vanquished by fate in the struggle for existence, has lately "turned up his toes" in the 


\section{Sextons and Scalengers}

most literal sense, and lies unburied, like Archytas, on the loose sand of a bare patch in a meadow. All carrion-eating creatures are $r$ a arkable for their powerful sense of smell: and the sexton beetles, like the vultures and condors, are no exception to the rule. They sniff their prey from afar: for where the circass is, there shall the carrion beetles be gathered together. All are enger to take their share of the feast, and still more to lay their eggs in the dead body. Some of them may crawl up from the immediate neighbourhood: others, summoned from afar, come flying on their gauze-like wings from considerable distances. They are, as a rule, nocturnal creatures, and they come out on their burying expeditions by night alone.

The insect just alighting from his flight, in the upper part of the illustration, is the burying beetle par excellence among our British kinds; he rejoices (we are always supposed to rejoice foolishly in our personal clesignations) in the dignified title of Necropluoris vespillo. In stature he measures about an inch long, and he is a handsome beast, with two bright orange bands on his hard wing-covers. The illustration shows these wing-covers raised, as is the habit of beetles when they $\mathrm{fly}$, while the thin but powerful wings beneath them are expanded as true pinions. When the insect alights, he folds the wings up carefully and replaces them under the hard protective wing-covers: he is then securely armour-plated from head to foot, and need fear no foe, save birds which swallow him whole-a very tough morsel-and hedgehogs which crunch him 


\section{IN NATURE'S WORKSHOP}

in their strong jaws before eating him. However, he is well prepared for all such enemies, for he can exude when attacked a very nasty fluid with a disgusting smell: and this mode of defence, which resembles that of the skunk and the polecat, usually protects him from obtrusive inquirers. He must be handled with caution, as the perfume he diffuses spoils woollen clothes and clings to the fingers after two or three washings.

As a rule, when a carcass appears, a pair of burying beetles of the same species-a husband and wife - fly up to the scene of operations together and take possession of the prey; though in the illustration Mr. Enock has represented several kinds engaged at once in staking out claims, which indeed happens often enough in nature. But if you count the number on any one dead bircl or animal, you will almost always find they are even in number - in other words, so many pairs, male and female. No. 2 shows us the next act in the funeral drama. The male beetles, after satisfying their own immediate hunger, proceed to bury the carcass in a very curious and laborious manner. You would wonder how so small a creature could produce so great a result : the fact is, the beetles attain their end by continuous under-cutting. The feriule hides herself in the body: the male buries her alive and the dead creature with her. He first drags the mouse, frog, or bird to a suitable spot where the soil is soft enough to admit of excavation; and sometimes three or four males have to combine for this purpose. They then proceed to dig with their heads, 


\section{SextoNS AND ScaveNGers}

wever, he can a dis. which sually must iffuses after

bury1 wife take ation aged pens iumnost ther D. 2 The iate ery oneat by self the se, is es Irls,

which are tools specialised for the purpose, and provided with strong and powerful muscles. The antenna have also assumed for this object a short club-shaped type, very suitable for a navvy's muttock. The little engineers begin by excavating a furrow all round the body, and then a second inside

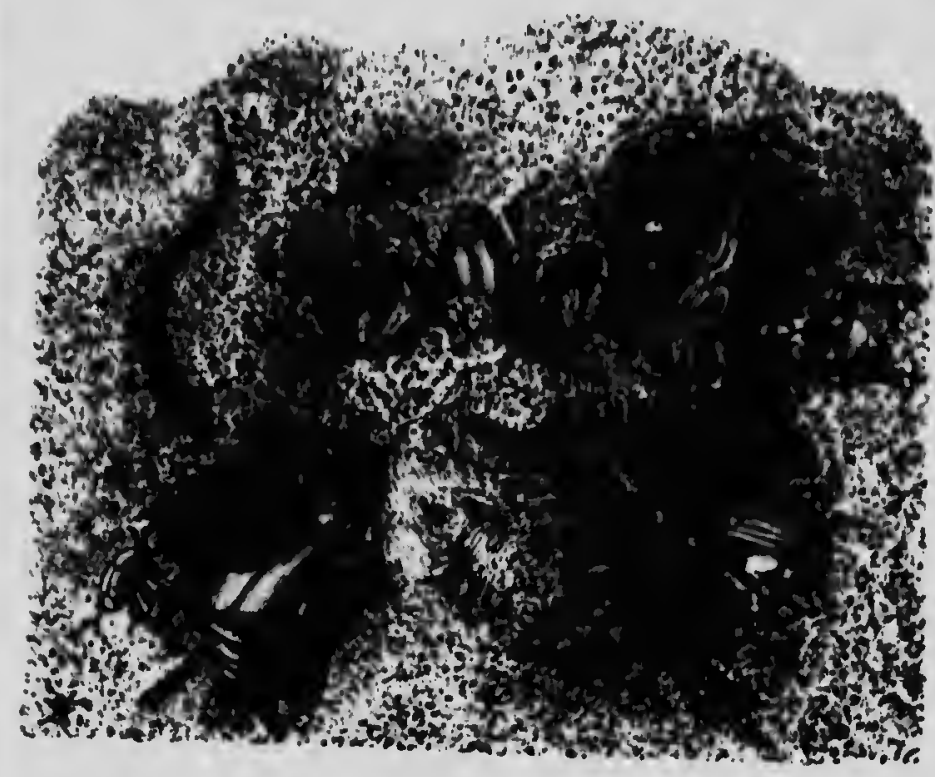

NO. 2. -THE SEXTONS AT WORK: BURYING THE BOUY.

that again, throwing the earth out of each into the previot:s one; and so on till the carcass begins to sink into the hollow. They then dig and tunnel beneath it, carrying out loads of earth, one after another, till bit by bit the carcass collapses into the hole, first in front, then behind, and has reached a level considerably below the surface. Then they 
throw in the earth they have excavated, and cover up the body with the females inside it ; after which, I regret to say, they proceed to hold a very cannibalistic funeral service above it. The funeral service consists in eating as much of the body as they desire for their own purposes: when they have satisfied their appetite, they begin to think of the interests of posterity. The mother beetle proceeds to lay her tale of eggs in the decently-buried body, for every animal knows by instinct the precise place in which to deposit its young, and the precise food which happens to suit them.

After the eggs are laid, the two parent beetles crawl out of the hole and cover it carefully up, so as to conceal the hiding-place. So far as they themselves are conserned, their only object in all this is to procure food for themselves and their infant young. But the wider effects of such scavenger insects go very far. For we now know that there is no disinfectant so good as the top layer of the soil, which is not really mere dead earth (as most people imagine), but a mingled mass of ramifying life-a little foundation of clay and sand intermixed with endless minute organisms, both animal and vegetable-fungi, bacteria, mites, weevils, and all sorts of petty creatures, which eat up and destroy harmlessly all dead matter subjected to their influence. The earth is thus a most admirable deodoriser and purifier : and burial in its top layers, the body being freely exposed to the rapid action of the devouring microbes, is a most sanitary mode of disposing of refuse. Thus the part that is 
cover which, canniervice desire isfied sts of $y$ her every hich hich etles , so they all heir scalow top ead ass nd ns, es, eat ed irp id played in the East by vultures and jackals, or by the wild dogs of Constantinople, is far more effectually and unobtrusively played in our fields and meadows by the many kinds of burying beetles and other insect scavengers. If we remember how

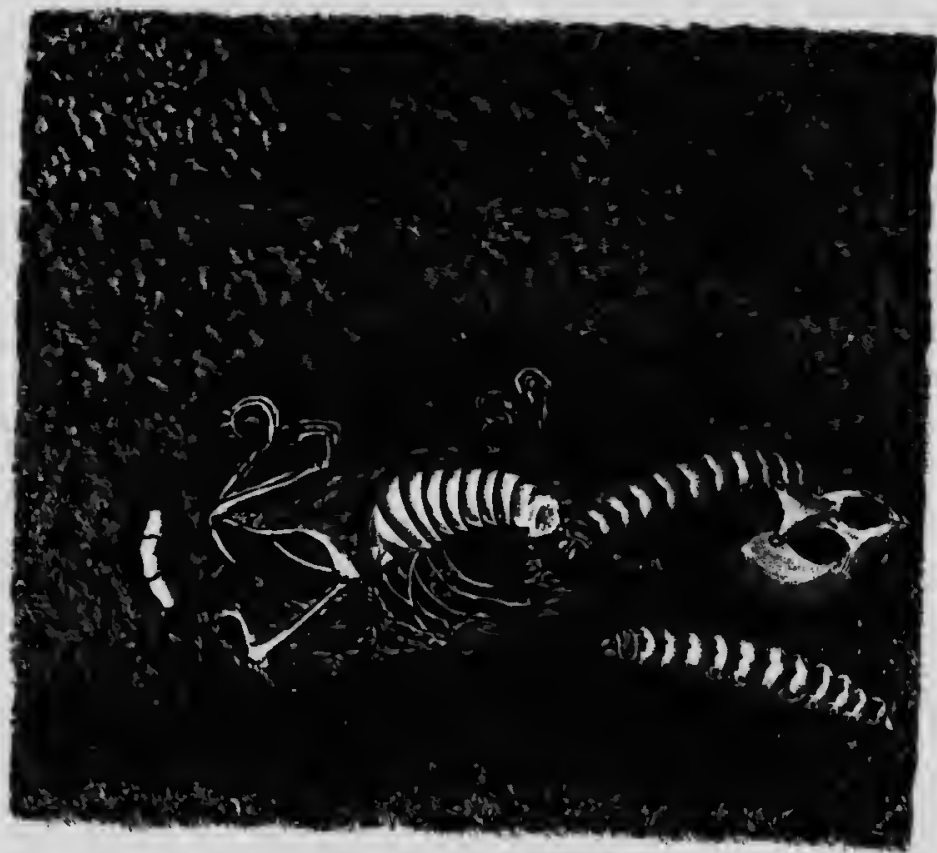

NO. 3. - THF, GRUBS UNDERGROUND : FEEDING UPON THE BODI.

great a nuisance a single dead rat becomes in a house, we can faintly picture to ourselves the debt we owe to these excellent and unnoticed little sanitary commissioners. Without them, our fields would not smell so fresh, nor would our flowers bloom so bright; for we must remember that by 


\section{IN NATURE'S WORKSHOP}

burying the dead beasts they are not only preventing disease, but also manuring the pastures in the best possible fashion. The bones of small animals decay rapidly, and make excellent material for the growth of vegetation. The beetles as a rule hunt by night only, and find their prey, as vultures do, by the sense of smell. When they first find it, the male hovers above it like an eagle, circling round and round, so as to point " it to his mate; the female ties straight to it, and buries herself without delay in the rich banquet.

But what becomes at last of the buried bodies? No. 3 will show you. The female beetle lays in each body about as many eggs as she thinks it will support. In a very short time the eggs hatch out, and the grubs begin to devour the abundant feast provided for them. The two grubs to the right in the illustration are the young of our friend the orange-banded burying beetle : the one to the left is a larva of an allied form known by the poetical name of Silpha. They set to work at once on the remains of the mouse, and thoroughly strip the bones of every fibre of flesh. As soon as the skeleton is bare, they consider it time to leave off feeding, and pass on to the second stage of their existence-
the pupa, or mummy-case.

As larva, the young burying beetles look like worms, and have six short legs. No. 4 shows them in the intermediate stage, when they have retired into a clay cell, or cocoon, and are undergoing their transformation into the perfect insect. We are here supposed to have removed the soil on one 


\section{Sextons AND Scavengers}

eventin the aimals or the hunt es do, t, the ound ; the thout

dies? s in will out, feast in the left tical the the eleng,

ike em ed ng $\mathrm{Ve}$ ne

side so as to give a view into the concreted earthen chambers where the pupre are changing into fullgrown beetles. You can see the much longer legs of the adult insect beginning to develop, while the head assumes slowly its later form. The grubs

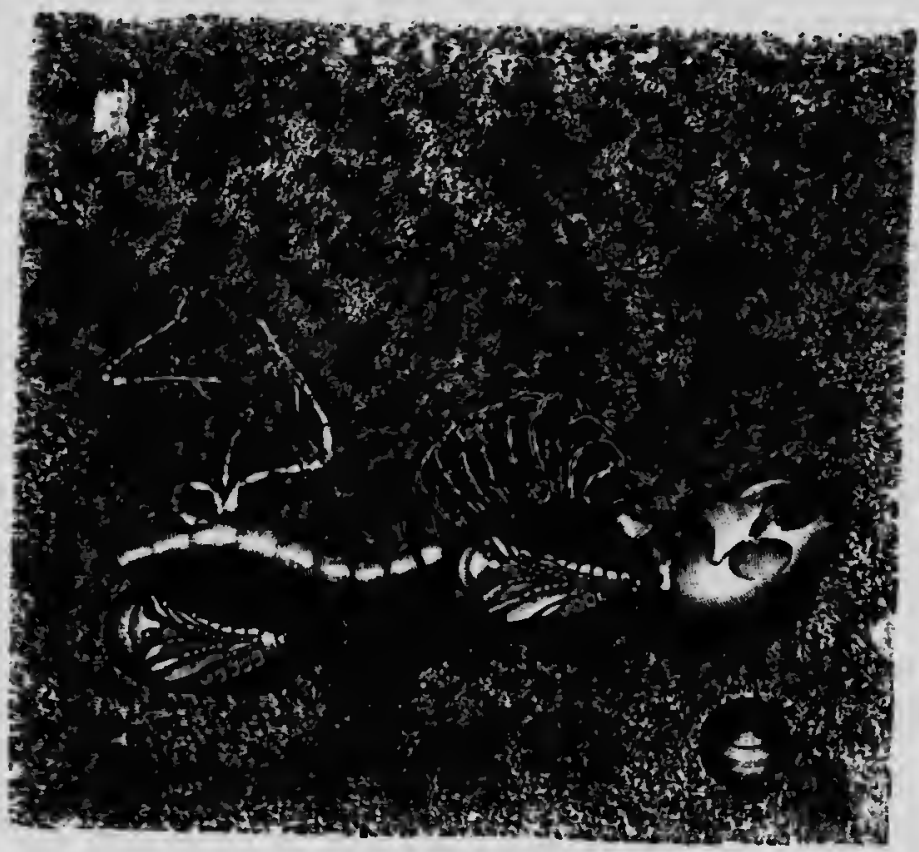

NO. 4. - NO MORE LEFT ! THE GRUBS IN THEIR COCOONS TURNING INTO BEETLES.

remain in the cocoon through the winter, and emerge in spring as winged beetles, when they fly away with their brilliant wing-cases raised, in search of congenial mates and more dead field-mice. The best places to look for all these beetles are the "keeper's trees," on which gamekeepers hang up 
the jays and weasels they shoot, to encourage the others. If you tap one such dead weasel you will generally find it is simply swarming with insect life.

Yet, strange to say, even the insect undertakers themselves are not without their ideas of beauty and their musical perceptions. The orange bands of our commonest English kind have been developed as attractions for their admiring mates; and the male beetles have also a musical instrument of their own in the shape of a peculiar rasplike ring on the body, which they can rub against the wing-cases, and so produce a much-appreciated chirping. Such instrumental music is always employed, like the song of birds, as a charm to heighten the attractiveness of the suitor : and male burying beetles may be heard on the evenings of sunny days competing with one another in musical contests. Indeed, it often happens that animals which seem to us disgusting or unclean display among themselves much æsthetic taste, and are gifted with more sense of beauty or love of music than many other forms where our human eyes would be more inclined to look for the presence of these higher endowments.

I may add that if the beetles left the bodies in which they laid their eggs to lie above ground, the bodies would dry up, and the eggs would run much greater risks. By burying the dead animal, they provide their young with food and shelter together, and so display considerable intelligence.

Another very distinct group of insects which act as scavengers in a different way in hotter climates 


\section{Sextons and Scavengers}

than ours are the famous scarabs or sacred beetles, worshipped almost like gods by the ancient Egyptians. English people know the scarabs best, I think, in the neighbourhood of Naples, or on the Lido at Venice - that great bank of sand and shingle which separates the lagoons from the open Adriatic. When wearied with sight-seeing at St. Mark's and the Doge's Palace, we have, most of us, taken the little steamer that runs across to the baths on the Lido, and spent a pleasant hour or two in picking up shells and dried sea-horses on the firm belt of beach that stretches away to Malamocco. A little inland, the beach gives way to dry sand-hills, blown about by the wind, and overgrown by patches of blue-green maram-grass and other sandy seaside weeds. If you lie down on one of these sand-hills, choosing a spot not quite so dirty as its neighbours, you will soon be amused by seeing a curious little comedy going on perpetually around you in every direction. A number of odd-looking beetles, with long hind legs and very quaint heads, are occupied with ceaseless industry in rolling a lot of dark, round balls almost as big as themselves along the slopes of the sand-hills. In many places, the whole ground is alive with the tugging and pushing little beasts : indeed, when you come to look close you will find that every half-acre of sand on the Venetian shore or the lower edge of the Egyptian desert is a perfect city of these busy wee creatures. Earth is honeycombed with their holes, towards which innumerable beetles are continually rolling their mysterious balls at every possible angle. 
Now, what are the balls composed of ? There comes the oddest part of the whole odc proceeding. The plain truth of it is that the sacred beetles are assistant scavengers-imperfect Southern and Oriental substitutes for a main drainage system. The balls consist of dung, dirt, and refuse, and the beetles collect them on the open, dry them hard in
the sun, roll them to the mouths of their burrows,
and then live on them till the ball and then live on them till the ball has all been eaten. It is the funniest thing in the world to watch them. They tumble about in the loose sand and, stumble over little eminences in the most engaged in this habitual and quaint amusement. They have each collected a round mass of manure, and rolled and dried it nicely into shape; they are now engaged in trundling their booty off at their leisure to a place of safety. But they are obliged to push the balls backward with their long hind legs : and as this precludes the possibility of the scarab seeing where it is going, each beetle pauses every now and again and turns round, like pauses sculling in a boat alone, to loo wat him. Sometimes in misfortune which hoing so he loses his ball, a on the right in No. just happened to the beetle bounding off down 5 . The precious pellet goes take it. In this ch hill as fast as gravitation will man faces round the disappointed little workgoing forward now darts after it at full speed, ing to head the ball nstead of backward, and tryslope of the sand-hills. If he succeeds, he puts 


\section{Sextons and Scavengers}

himself in front of the ball as it falls, catches it with his hind legs, and begins once more laboriously to push it backward up hill again, towards the mouth of his hole. But as the pellets roll quickly, and the beetles are by no means rapid runners, he seldom

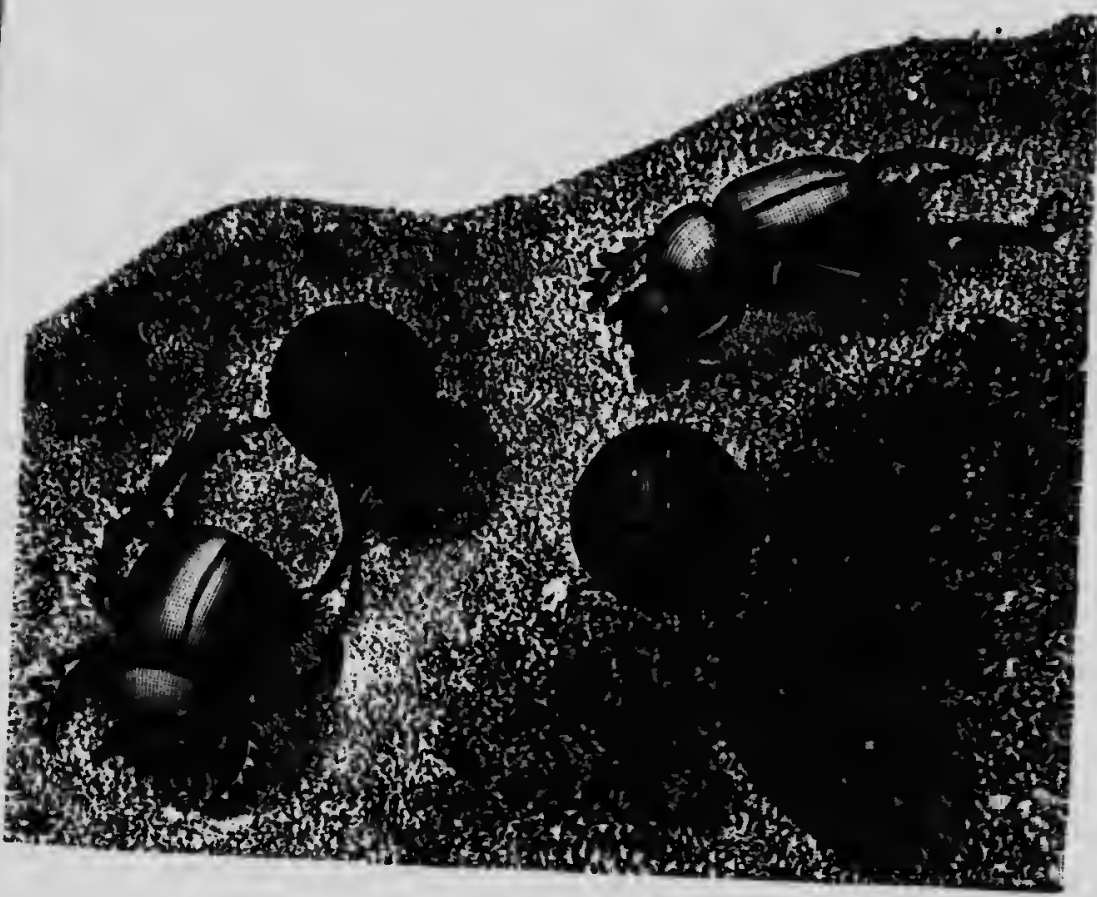

NO. 5. - SACRED SCARABS ROLLING TILEIR FOOD-BALLS BACKWARD (THE INSECT TO TIE RIGHT HAS LOST HIS DINNER).

succeeds in recovering his own property, unless the ball happens to catch for a moment on some projecting little hillock of sand, or be checked on its downward course by a weed, a stick, or a dead shell or startish. 
On the other hand, the scarabs, I fear I must admit, are terrible thieves; and if one scarab has lost his own ball, and sees some companion's pellet come rolling down hill towards him, he will often give up the pursuit of his lost property, and quietly and birefacedly appropriate his neighbo.ır's. I have seen great fights take place at times over a disputed ball ; though sometimes the cumbatants agree amicably to roll it along in common, and probably share it when they have reached their hole. Sometimes, again, three or four will unite to roll a ball: and then, when one loses it, the others combine to hold it up or catch it. I have spent hours together both in Egypt and on the Mediterrariean or the Adriatic in watching the queer antics of these comic little commissioners of drainage : and I never tire of observing their odd and unexpected combinations of intertst. I have sometimes known the real owner abandon a ball in de. spair from the unevenness of the ground, and then seen a couple of outsiders come up and succeed in doing what the true owner had been unable to accomplish.

In No. 6 you see two such scarabs whose toil has at last been crowned by success, and who are delivering their balls with joy into the holes in the sand which form their residences. As far as I can make out, a pair of beetles, male and female, seem usually to share a hole in c-mmou, and to roll balls of food to it either alone or in concert. I cannot say I have ever seen much co-operation
except between such partners. Once a ball is 


\section{Sextons and Scavengers}

secured and safely landed-for here, as elsewhere, there's many a slip 'twixt the cup and the lip-the happy couple proceed to eat it up, and apparently do not emerge again from their burrow till the supply is exhausted. Patient naturalists say that

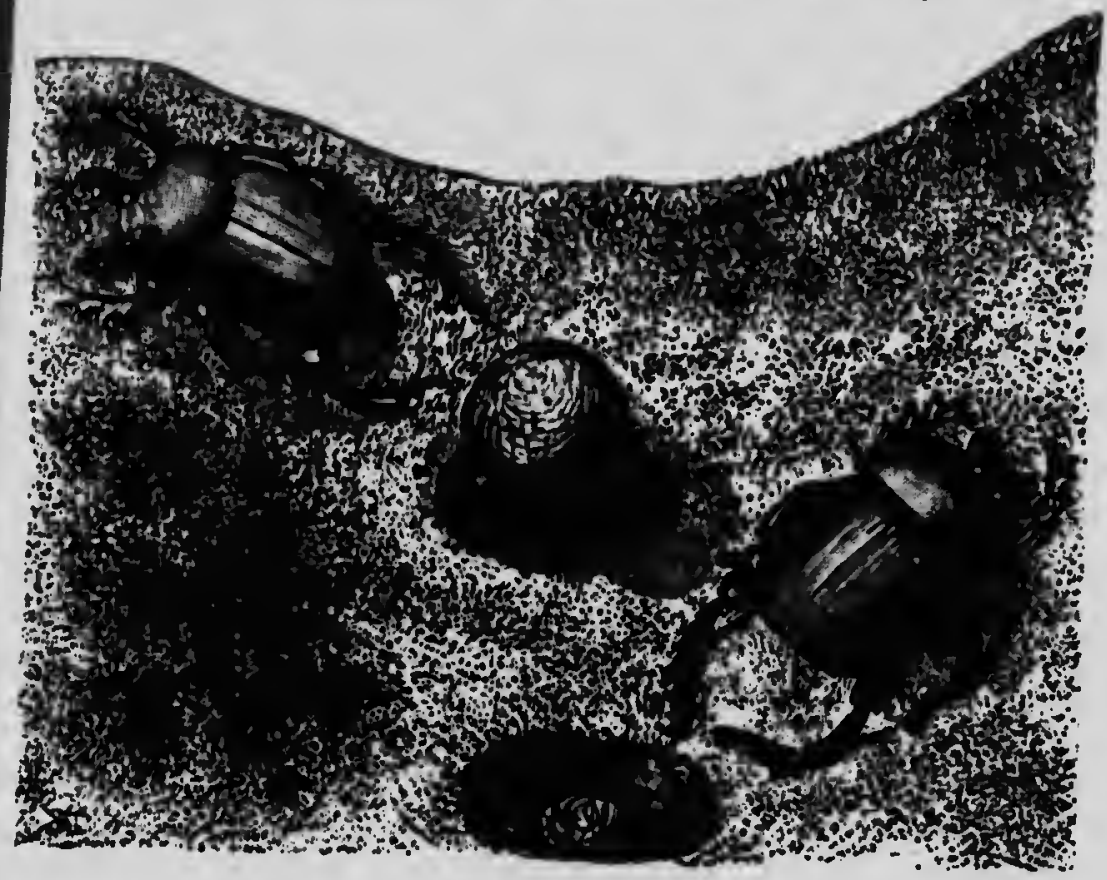

NO. 6. - PRIMITIVE GOLF-RNII OF A ROUND: THE SCARABS HOL.ING THEIR BALL.S.

one ball has been known to last a scarab as long as a fortnight, but this I do not vouch for of personal knowledge. When more food is wanted, the couple emerge once more on the open sand and begin to collect fresh dung and refuse, which they roll into a new food-ball and then dry and harden. 
Till very lately, it was universally believed that the female scarab laid an egg in some of the balls, and that the young grubs hatched within such food. stocks, and began at once to devour them. This belief has recently been, contradicted with great emphasis by a good French observer, who opened many balls and found no eggs; but I cannot accept his conclusion. I have opened numbers of balls myself near Venice, and seen in several one or two eggs, while in one case (unearthed from a hole) I discovered a half-grown larva. I venture therefore in this matter to believe my own eyes as against those of even the most celebrated and authoritative
entomologists. 1

In Egypt, it has been universally believed from all antiquity-and I think quite rightly-that after the scarab has laid an egg in the ball, the parents unite in rolling it to a place of safety, above the level of the annual inundation due to the rise of the Nile. At any rate, scarabs abound in Egypt. At a very early date, it would seem, the curious action of these beetles attracted the attention of the ancient Egyptians, whose worship of animals was one of the most marked features in their monstrous religion. Hence grew a strange and widespread superstition. A race which deified the hawk, the cat, the ibis, and the jackal was not likely to overlook the marvellous proceedings of the pious and beautiful scarah. So the very early Egyptians, we may conjecture, began by thinking there must be something divine in the nature of an insect which worked so ceaselessly on behalf of its young, and 


\section{SExrons AND ScavenokRs}

rolled such big round balls behind it up such relatively large hillocks. Watching a little closer, as time went on, the Egyptian discovered, no doubt, that sacred beetles did not proceed directly from sacred beetles, like lambs from ewes, but grew, as it were, out of the dirt and corruption of the mysterious pellets. A inodern observer would, of course, at once suspect that the scirab laid an egg inside the ball, and would promptly proceed to pull one open and look for it. But that cold scientific method was not likely to commend itself to the mystic and deeply religious Egyptian mind. The priests by the Nile jumped rather to the conclusion that the scarab collected dirt in order to make a future scarab out of clay, and that trom this dirt the young beetle grew, self-existent, selfdeveloped, self-created. Considering the absence of scientific knowledge and comparative groups of scientific facts at the time, such a conclusion was by no means unnatural.

Once started on so strange a set of ideas, the Egyptians proceeded to evolve a worship of the scarab which grew ever and developed, as they thought the scarab itself did, practically out of nothing. The immortality of the soul and the resurrection of the body were the central ideas of Egyptian religion; the thinkers of Thebes and Memphis instantly perceived a fanciful analogy between the scarab rising from its bed of dirt and the muminy reviving when the expected day of resurrection should at last arrive. As a consequence of this analogy, the scarab was made 


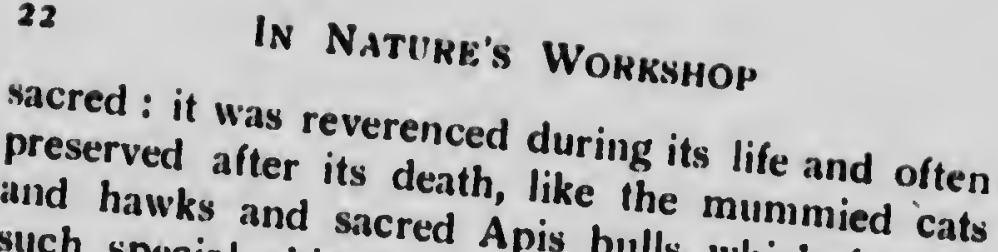
and hawks and sacred Apis bulls which formed such special objects of veneration to the devout of Egypt. All sorts of mystic relations were also discovered before long in the scarab: its "toes" were counted as thirty, and held to symbolise the days of the month : it was said to be male only,
without a female, and so to typify the creative
power and the paternal or masuling power and the paternal or masculine principle in nature. Sun-worship, as we know, formed a large part of the later (though not of the inost primitive) Egyptian religion: and the ball rolled by the scarab was therefore supposed to personify $\mathbf{R a}_{\text {a }}$, the great sun-god. In one way or another the sanctity and the mystic implications of the scarab grew and grew, age after age, until at last scarabworship became one of the chief practical clcase.t.
in the religion of Egypt. There was headed god, and scarab hieroglyphs appear on the face of all the monuments.

It is as a charm or amulet, however, that the ancient Egyptian imitation scarab is best known. From a very early period in the history of the Nile valley it became usual for luck's sake to bury no doubt creep out in which case most of them would A few real scarabs ain), and perhaps also dead. and there on tomb have thus been found here as the Egyptians buried But for the most part, just accompany the mummy, so porcelain images to 
or stone scarabs; and these were rather closely imitaled from the living insect, but made still more sicered by being enamelled or engraved with the holy name of some king or god. Scaralss of this kind, inscribed with sacred words, and regarded as talismans, form some of the commonest objects disinterred in all the Egyptian excavations : one of them, from a specimen in the British Museum, is illustrated in No. 7. Comparison with the live beetles in the other engravings will show how well the Egyptians copied nature in this instance.

These beautiful and often costly Egyptian scarabs have been made the subject of very exhaustive study by various writers, more particularly by $\mathrm{Mr}$. Loftie and Mr. Flinders Petrie. The Egyptians did not coin money, so that

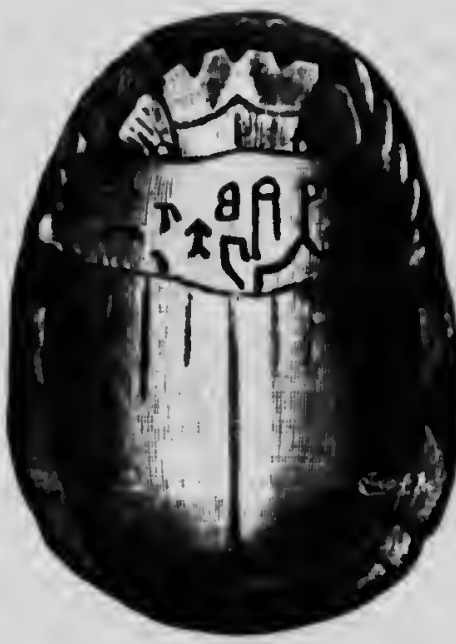

No. 7.-AN EGYPTIAN SACREI SCARAB, IN THE BRITISII MUSEUM.

scarabs bearing the names of kings came to have somewhat the same importance for Egyptian history as coins have for the history of later civilised nations. Mr. Loftie traces the origin of the inscribed scarabs to a very early epoch in the Egyptian annals. "From the earliest times until the end of the native monarchy," he says, "certain usages continued unclianged. Among them 
was the inscription of names and texts on scarabs. The beetle which rolis before it "- on ought rather to have said belind it-"a hall of mud in which its egg is concealed was, at some period so remote that we cannot even approximately date it, seized upon as the embodiment of the idea of futurity. . . The scarab, burying his egg, became the symbol of the resurrection, of the happy time to come, of a re-creation of all things; and with every corpse scarabs were buried, and scarabs were sewed upon the shroud, and strung into a network to cover the body, and suspended round the neck, and clasped in the dead hands. As many as three thousand scarabs have been found in one tomb, and the number in existence in museums and private past count." Some of these private collections is of blue pottery, enamelled imitation beetles are of lapis-lazuli, inders are precious stones. carnelian, and many other very form, that of thacred in themselves by their rendered still more revered insect god, they are tions, which consist of appred by their mystic inscripin hieroglyphic writing.

From engraved scarabe belief in the luck and value of to the Greeks, and charms or amulets passed on Greek scarabs have also to the Etruscans. Many Etruscan tombs been found; and in the old tively common. less in imitation of the mostly made more or enough, even the early Chyptian originals. Oddly 
not at once get over the belief ia tio sanctity and talismanic character of the sacred lieetle, for the Rev. W. J. Loftie has po.ited out ex tinples of late scarabs engraved with undoubted C! ristian symbols -not only crosses but even crucifixes. In our own days, a slight revival of the antique superstition has once more taken place, and some ladies of my acquaintance wear specimens of tr: old sacred beetles as charms in brooches or suspended on their watch-chains.

Though such numbers of true ancient scarabs have been unearthed in Egypt, still the supply of the genuine article does not quite keep pace with the increasing demands of the ordinary tourist; and there is now a flourishing manufactory of sham antiques at Luxor, where hundreds of false scarabs with nice imitation hieroglyphic inscriptions are neatly turned out for the market every season.

About sixty different kinds of live scarabs are known to inhabit the Mediterranean district in Europe, Asia, or Africa: and four of these kinds can be easily distinguished as being individually represented in the old Egyptian gems. We have no true scarab of this class living in Britain; but there are other scavenger beetles which take their place, the best known being the common dor-beetle. One of the same family, but with a quaintly horned head, exists in vast numbers on the Surrey hills where I have pitched my tent. This English dungbeetle burrows in the soft sandstone, and throws up neat little heaps of clean sand at the mouth 

26 IN NATURE's Workshop
of its hole, like miniature mole-hills. Still, our
English scavenger beetles-known to science as
Geotrupes-are not nearly so clever Geotrupes-are not nearly so clever or so interesting as the southern type, for the female in our sort merely grubs a straight tunnel in the ground, and lays her egg in a loose mass of dung, which she drags to the bottom in a shapeless condition. This
beetle utters a plaintive buzzing cry when it is
chasing its mate-a sort of "l chasing its mate-a sort of "last appeal" which seems calculated to soften the heart of the hardest lady beetle. It is as cunning in its way as most others of its race, for if you catch it in your hand, it at once draws in its legs to its side and "shams dead." All the English and foreign scavenger beetles perform a useful task by following up
animals and clearing away their refuse; indeed,
a special kind of beetle lays itself out as a special kind of beetle lays itself out as scavenger for each species of large animal, one kind being attached to the cow, one to the donkey, one to the camel, and so on through a long list of patrons and
satellites.

You will thus see that in this wider sense all creation moves together like a vast joint-stock co-operative society, each kind working consciously for its own good alone, but each also in a certain deeper and unconscious way contributing to the general well-being of all, by its exercise of some special function. Nevertheless, the function is always performed by each plant or animal itself for its own purposes; it only incidentally serves to benefit the others. Thus the burying beetles and the scavenger beetles work first of all and 
ostensibly for their own food and the food of their offspring: it is merely as an incidental result, undesigned by themselves, that they assist in purifying the air and the soil for all other species. Or, to put it still more simply, while these industrious little creatures are working individually for their own ends, they are also in the wider scheme of nature working unconsciously and almost unwillingly in the service of others. Nature bribes each kind, as it were, by some personal advantage to perform good work for the benefit of the totality.

The good work performed by the scavengers may be thus summed up. If dead bodies and the refuse of food were left about everywhere freely on the open, germs of disease and putrefaction would fly about much more commonly than even at present. But a large number of scavenger animals, scavenger birds, and scavenger insects-hyenas, vultures, burying beetles, and so forth - act as public servants to prevent this calamity. Again, the earth needs the bodies and the refuse as fertilisers: and many of the scavengers carry down such materials into the first layer of the soil, where they become of enormous use in promoting the freer growth of vegetation. Thus, long before men learnt to bury their dead or to manure their fields, nature had invented both these processes, and registered them, so to speak, in the instincts and habits of a special class of insect sextons and sanitary inspectors. It is always so in life. There is hardly a human trade or a human activity 
28

IN NATURE'S WORKSHOP

which does not find its counterpart somewhere in animal or vegetable life : and it will be my other direction chapters, to set before you in or foreshadowings such natural anticipations man's inventions. 


\section{FALSE PRETENCES}

$\mathrm{H}$

UMAN life and especially human warfare are rich in deceptions, wiles, and strat-gems. We dig pitfalls for wild beasts, car: fully concealed by grass and branches; we take in the unsuspecting fish with artificial flies, or catch them with worms which conceal a hook treacherously barbed for their surer destruction. The savage paints his face and sticks feathers in his hair so that he may look more terrifying to his expected enemy; civilised men mask their batteries, and sometimes even paint muzzles of imaginary guns in the spaces between the gaping mouths of the real ones. Chevaux de frise block the way to points liable to attack; real troops lie in ambush and dart out unexpectedly in the rear of the assailants. Trade in like manner is full of shams-a fact which I need hardly impress by means of special examples. But Nature we are usually accustomed to consider as innocent and truthful. Alas, too trustfully: for Nature too is a gay deceiver. There is hardly a device invented by man which she has not anticipated: hardly a trick or ruse in his stock of wiles which she did not find out for herself long before he showed her. 
I propose in this chapter to examine a few cases of such natural deceptions-not indeed the most striking or typical, but such as occur among fairly well-known English plants and animals. And I shall begin with our familiar and unsavoury old friend, the Devil's Coach-horse.

In order fully to understand his mode of procedure, however, I must first call your attention to another animal which really is what the Devil's Coach-horse mendaciously pretends to be: and that is the common scorpion. His mode of fighting is well known to most of us. In illustration No. I Mr. Enock has given us a delineation of a frantic death-struggle between such a scorpion and a large and powerful southern spider. The venomous creature with the stinging tail is on the left; the spider is on the right. As far as mere size goes, the antagonists are fairly well matched; but the scorpion is the best armed, both with offensive and defensive armour. His lobster-like or crablike claws enable him to hold his enemy's limbs in his grip as in a vice; then, at the critical moment, he bends over his tail, in the extremity of which his sting is situated, and plunges it with force through the comparatively slight skin of the spider's body or thorax, injecting at the same moment a pungent drop of his deadly poison. This characteristic action of the scorpion in curving its tail over its body and raising its sting in a menacing attitude is well known to birds and other enemies of the species: often the mere threat of $\partial$.thrust is a sufficient deterrent : the dangerous beast just 
elevates its poisonous appendage or assumes an angry mien, and the inquisitive intruder is frightened away immediately. It is the same with ourselves. The bare sight of thai uplifted sting suffices to repel us. Even a child who saw a scorpion once arch its back and prepare to strike with its reversed tail would instinctively understand that there was

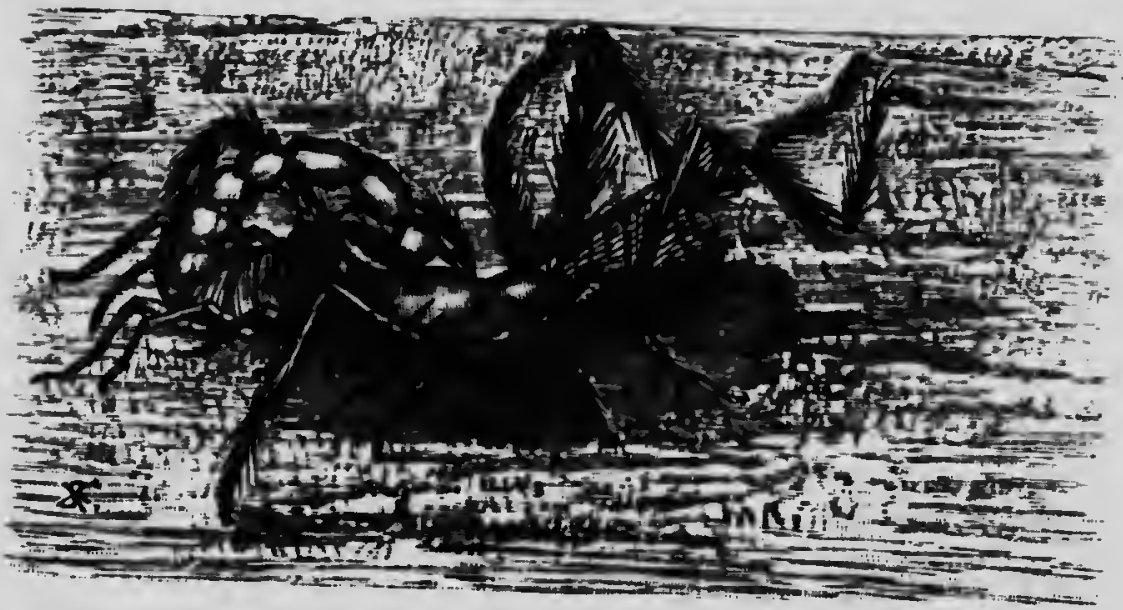
NO. 1.-A BATTLE ROYAL: SCORPION $v$. SPIDER :
THE SCORPION STRIKING.

danger ahead, and would withdraw its hand before the venomous creature had time to pounce upon it.

Owing to these unamiable personal traits of the scorpion race, it is not popular among other animals. But to be feared is to be respected; and scorpions for the most part are left severely ilone, under the stones where they love to lurk, by the 
various denizens of the districts they inhabit. Now, it is a fact in nature as in human life that to be successful is to have many imitators. Thus a number of harmless flies dress up like wasps in black and yellow bands, and so escape the too pressing attentions of insect-eating birds and other enemies. They have no stings, to be sure, but they look so like the wasps, and flaunt about so fearlessly in their borrowed uniform, that they are universally taken for the insects they mimic : even the cautious entomologist himself stares at them twice and makes quite sure of his specimen before he ventures to lay hands on any such doubtful masquerader. I shall in a later article give some further account (with illustrations) of these facts of mimicry, as it is called: for the present we will stick close to our text, the Devil's Coachhorse. For this familiar English beetle is an imitator of the scorpion, and obtains immunity from the attack of enemies to a great extent by pretending to powers which are not his in reality.

In No. 2 we have a portrait of the Coach-horse in his hours of ease, seen from above, engaged in doing nothing in particular. He does not look like a flying insect, but he is. $\mathrm{He}$ has a long pair of wings tucked away in folds under his horny wingcases, and he can use them with great effect, for he is one of our swiftest and strongest fliers-the long-distance champion, I almost fancy, among the beetles of England, unless indeed the tiger-beetle be pitted against him. But when crawling on the ground, and attacked or menaced, he does not take 
to flight or show the white feather: being a pugnacious and spirited little beast, he bridles up at once, and endeavours incontinently to terrify his assailant. In No. 2 you see him from above when he is merely engaged in rawling along the ground, looking as mild as milk, and as gentle as any sucking dove: you would hardly suppose he could show fight or raise his hand -I mean his antenne - to injure any one. But in No. 3 he is represented in his favourite act of attacking a caterpillar: for he is really a very voracious and courageous carnivore. In the autumn, when Devil's

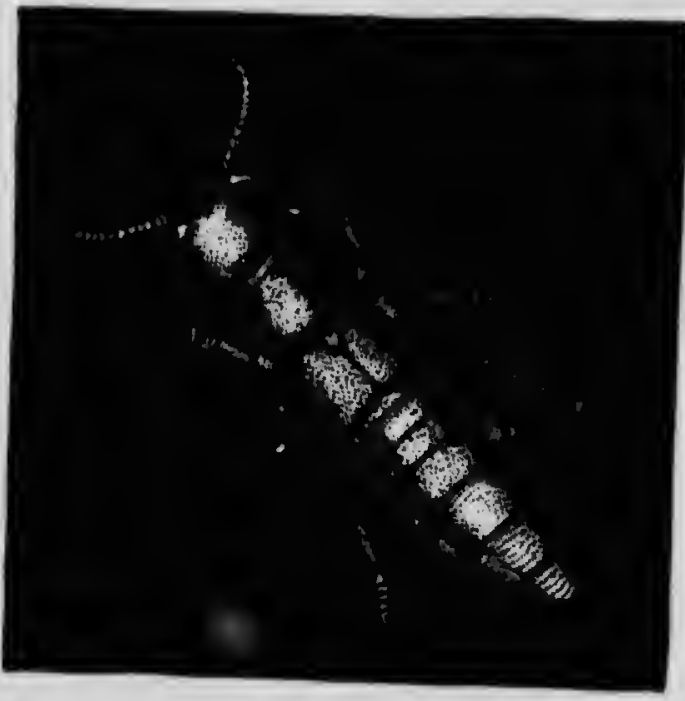

NO. 2.-THE DEVIL'S COACH-HORSE IN UIS HOURS OF EASE.

Coach-horses are usually most abundant, you can easily catch them by putting a piece of meat or a dead frog under an empty flower-pot, and then tilting the edge up with a stone, so that the beetles can crawl in and get at the food thus temptingly
laid out for them.

If you disturb the Coach-horse, however, while he is engaged in eating his quict meal, or even 
when he is walking at leisure along it comntry road, he puts himsel at once into his "terrifying" attitude, and imitates the scorpion. No. 4 exhibits him in this military chatacter, cocking up his tail and pretending leceill sting-which is only his hrag : he just does it to frighten you. But the attitude is so exactly like that of the scorpion, that it almost always produces an immediate effect : hardly anybody likes to molest a Devil's Coach-horse. If you put down your hand to touch him, and he rears 11

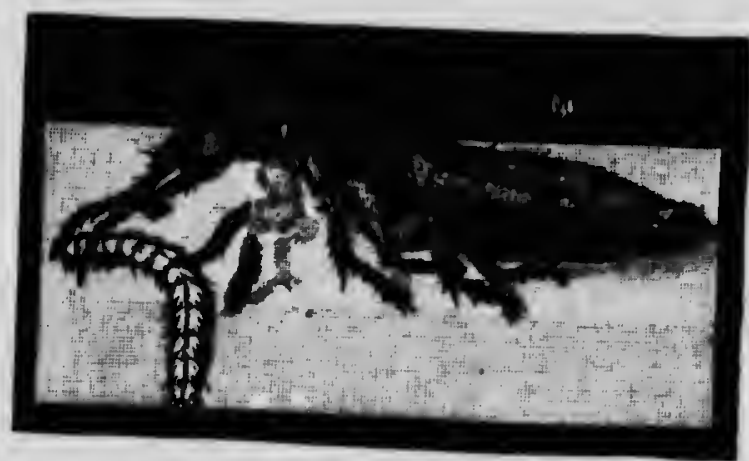

NO. 3.-THE DEVIL'S COACH•HORSE SAMPLING A CATERPILLAR.

response, ten to one you will withdraw it in alarm at sight of him. In England these beetles often enough find their way into larders or cellars, seeking whom or what they may devour; and when the servants light upon them, they almost invariably decline to touch them : there is a general opinion about that the ugly and threatening black beasts are uncanny and poisonous, or else why should they turn up their tails at you in such an insulting 
"But," you may object, " there are no scorpions in England : how then can the Devil's Coach-horse be benefited by imitating an animal which he has never seen, and of whose very existence he has not been able to read in pretty picture-books?" Your objection has some force-though not so much als you imagine. It is quite true that there are no scorpions in England; but then, there are Devil's Coach-horses in many other countries, and the habit of tail-cocking need not necessarily have been acquired in these islands

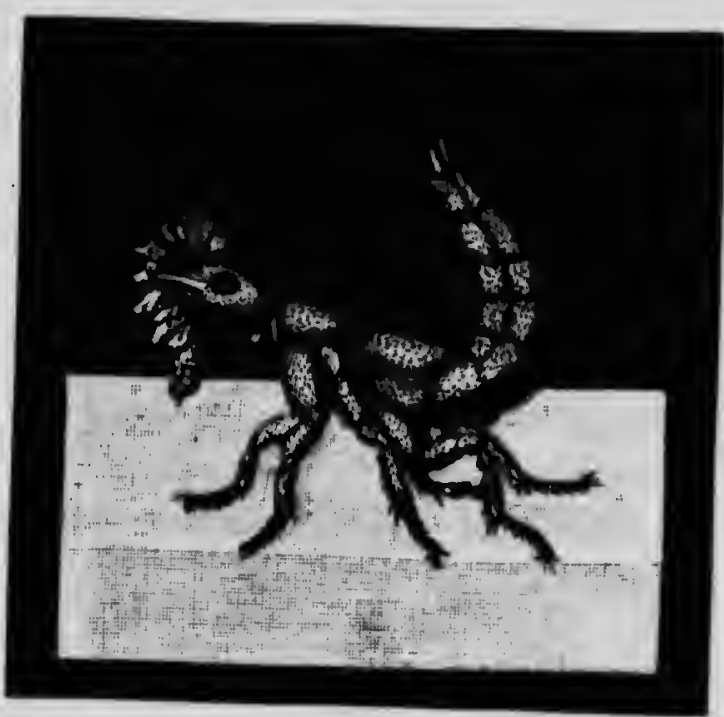

NO. 4 -THE DEVII'S COACH-HORSE PRETENIS TO HE A SCORPION. of Britain.

That is not all, however : it suffices the beetle if the tactics it adopts happen to frighten and repel its enemies, no matter why. Now, in the first place, many of our migratory birds go in winter to Southern Europe and Africa-especially the insect-eaters, which can find 110 food in frozen weather. The hard-billed seed-eaters and fruit- 
eaters remain with us, but the soft-billed kinds retire to warmer climates, where food is plentiful. Of course, however, it is just these insect-enting birds that the Devil's Coach-liorse has most to fear from. 'The birds must be quite familiar with the habits and manners of scorpions in their southern homes; and they are not likely to incyuire closely whether the dangerous beast they know on the Mediterranean has, or has not, been sclieduled in Britain. We all of us dislike and clistrust any insect that resembles a bee or wasp, and that buzzes or hums in a hostile manner; we give all such creatures a wide berth, wherever found, on the bare off-chance that they may turn out to be venomous-be hornets or so forth. Just in the same way, a bird when it sees an unknown black beastie cock up its tail and assume a threatening attitude, is not likely to inquire too curiously whether or not it is really a scorpion : the bare suspicion of a sting is quite enough to warn it off from interfering with any doubtful customer. Moreover, in the second place, even those birds or men who have never seen a scorpion at all are yet sure to be alarmed when an insect sticks up its forked tail menacingly, and shows fight, instead of skulking or flying away. As a general rule, if any animal makes signs of resistance, we take it for granted he has adequate arms or weapons to resist with : and so this mere dumb-show of being a sort of scorpion proves quite sufficient to protect the Devil's Coach-horse from the majority of his enemies. 
I ought to add that while our beetle thus frightens larger enemies, he is actively and offensively objectionable to small ones. The main use of his tail, indeed, is for folding away his wings, much as the earwig folds hers by aid of her pincers. But the Devil's Coach-horse makes it serve a double purpose. For he has a couple of yellow scentglands in his tail, which secrete an unpleasant and acrid aromatic substance. These scent-glands are protruded in No. 4 : you can just see them at the tip of the tail; and if the annoyance to which the beetle is subjected seems to call for their intervention, a drop of the volatile body they distil is set free, and is at once clischarged in the face of the enemy. Sucl a manouvre is in essence like that of the skunk : it is defence by means of a nasty odour, and it occurs not only in the Conch-horse's case, but also among a number of beetles and other insects.

The odd little creatures known as 3ombardier Beetles are still quainter in their habits : they carry the last-mentioned inode of clefence to an even greater pitch of perfection. For, like miniature artillery-men, they actually fire off a regular volley of explosive gas in the faces of their pursuers. The gas is secreted as a liquid; but it is very volatile, and it vaporises at once on contact with the air, so as to form a small, white cloud of pungent smoke, resembling in its effects nitric acicl. Our native English species of Bombardier roams about in large flocks or regiments : and when one member of a clan is disturbed, all the other heetles of the 
company let off their artillery at once, so that the scattered volley has something the appearance of platoon firing. The chief enemy of the Bombardiers is a much larger and very handsome carnivorous beetle known as Calusoma. When this insect tiger hunts down a single Bombardier, and has almost caught him, the fugitive waits till his pursuer is quite close, and then salutes him with a discharge of fire-arms : the pungent gas gets into the Calosoma's eyes and mouth and distracts him for a moment; and the Bombardier escapes in the midst of the confusion thus caused, under cover of the cloud he himself has, exploded. That is the most highly evolved mode of defence of which I know among the British insects.

There are few creatures, again, which one would so little suspect of any attempt to bully and bluff others as the soft-bodied caterpillars. They are as a rule so plump and squashy and defenceless : a mere peck from a bird's beak is enough to kill them, for when once their tight, thin skin is broken, were it but with a pin-prick, all the flabby contents burst out at once in the messiest fashion. Yet even caterpillars, strange to say, have their tricks of terrifying. They pretend to be dangerous characters. I will set out with some of the simplest and least developed cases, and then pass on to a more complex and wily class of deceivers.

To begin with, I must premise that two sets of caterpillars have two different ways of evading the unpleasant notice of birds and other insect-eaters. One way is that adopted by the common "woolly- 
bear," a great hairy caterpillar, frequent in gardens, and covered from head to tail with long needles or bristles. These prickly points make the creature into a sort of insect hedgehog; birds refuse to touch him, because the serried spikes, which to us are mere hairs, seem to them perfect spines or thorns, sticking into their tongues and throats, or clogging their gizzards. Protected caterpillars like the woolly-bears live quite openly, exposed on the leaves and branches of their food-plant; they are not afraid of being seen : nay, they rather court observation than shun it, because they know nobody will attack them. The porcupine has no need to run away like the rabbit. Similar tactics are also adopted by many nasty-tasting caterpillars, in whose bodies natural selection has developed bitter or unpleasant juices. These caterpillars are rejected by birds and lizards-the great enemies of the race-and therefore they find it worth while to clothe themselves in gaudy and conspicuous red or yellow bands, so as to advertise all comers of their inedible qualities. Whenever you see such brilliantly-attired grubs (like those of the Magpie Moth, so common on gooseberry bushes-a striking creature tricked out in belts of black and orange), you may be sure of two things : first, they live openly and undisguisedly on the leaves of their food-plant, without any attempt at mean concealment ; and second, they are nasty to the taste, and therefore rejected as food by insect-eating animals. Now and then a young and inexperienced bird may eat one, to be sure; but it never tries twice, 
and the solitary martyr is sacrificed for the good of the race. Their bright colours and gaudy bands are just advertisements, as it were, of their inedible qualities. For, of course, nasty taste would do a caterpillar no good if the bird had always to sample it before rejecting it; the broken skin alone would be enough to kill it. Hence almost all uneatable caterpillars have acquircd bright colours by natural selection-that is to say, by the less bright being continuously devoured or killed; and birds on their side have learned to know (after one trial, or, perhaps, even before it by inherited instinct) that red or, yellow bands and belts in caterpillars are the outward and visible sign of uneatableness.

The second group or set of caterpillars is edible and tasty : it, therefore, governs itself accordingly, and has recourse to the exactly opposite tactics. Caterpillars of this class are smooth and naked: they never have the brilliant "warning colours" of the nasty-tasted kinds: and they show a marked absence of the beautiful metallic sheen, the strange melting iridescent hues and spots which add beauty to the charms of so many among the uneatable species. Such fat and smooth-skinned edible caterpillars are, of course, very tempting juicy morsels to birds and other insect-eating animals. Their motions, like those of all grubs, are slow; and if they lived exposed on their food-plants, after the fashion of the protected hairy and bitter kinds, they would all be eaten up before they had time to turn into moths or butterflies. Here, therefore, natural 


\section{False Pretences}

selection has produced the contrary result from that which it produces among protected kinds. Caterpillars of this edible type which showed themselves too openly and imprudently have got picked off by birds, like sentries and pickets who make themselves too conspicuous to the enemy's sharpshooters. Only the most prudent, modest, and retiring grubs have survived to become moths or butterflies, and so be the parents of future generations, to whom they hand on their own peculiarities. In this way the edible caterpillars have acquired at last a fixed hereditary instinct of lurking under leaves, or in dark spots, and never showing themselves openly. The larva of the butterfly group as a whole thus fall into twa great classes (as far as regards habits alone, I mtan) : the protected, which are either hairy or nasty, and which flaunt themselves openly ; and the unprotected, which lurk and skulk, endeavouring to escape notice as sedulously as their rivals the protected endeavour to attract it.

Nor is that all. It would clearly be useless for a bright red or yellow caterpillar to hide under a green leaf, and then suppose by that simple device he was going to escape observation. Birds are always looking out for insects under leaves. The consequence is that skulking or lv-king caterpillars are soon found out by sharp-eyed and hungry enemies, unl s'; they closely resemble the foliage or stems upis which they lie. From generation to generation, accordingly, the less imitative insects get eaten, and the more imitative spared : so that nowadays most unarmed caterpillars are green like 
the leaves or grey like the stems, and are even provided with markings of light and shade upon their skins which mimic the distribution of light and shade among the ribs and veins of the surrounding foliage. Such deceptive leaf-like caterpillars are always very difficult to find: so that careless observers as a rule know only those of the other type, the great hairy "woolly-bears" and the brilliant red and yellow-banded bitter kinds; they never observe the unobtrusive green and brown sorts, which harmonise so admirably with their native tree in colour and markings.

Many greenish caterpillars, however, when discovered and disturbed, fall back on their second line of defence: they endeavour to frighten their enemies by devices closely similar to those of the Devil's Coach-horse. The caterpillar of the Broadbordered Bee-hawk, for example, forms a good instance of a very simple stage in the development of such brazen-faced "terrifying" tactics. This warlike grub is shown in No. 5 , trying on its simple little attempt to make itself alarming. Though by no means an uncanny-looking or appalling insect, it will rear itself up on its haunches (so to speak) when attacked, raising the fore part of its body erect with a sudden jerk, and holding its head high, as if it meant to bite or -sting, so as to give itself as formidable an aspect as possible. The mild ruse succeeds, too; for birds will eye the harmless creature askance when it attempts this evolution, putting their heads on one side, and ruffling their crests in evident terror. The attitude is all a simple 
piece of bluff, to be sure, but it pays; indeed, bluff in warfare is often more than half the battle. If you put on a bold face in a row, and seem able to take care of yourself, people are apt to think you have a knife up your sleeve, and therefore to refrainfrom unnecessarily annoying you.

The cunning caterpillar which finally develops into the Privet Hawk-moth has a slightly more evolved mode of purely theatrical frightening. You see him in No 6, a full-fed specimen, just ready to turn at once into a chrysalis. This grub feeds usually on the vivid leaves of the privet; he is therefore protectively coloured a bright green, !ike that of the foliage about him. "But why those great purple stripes on

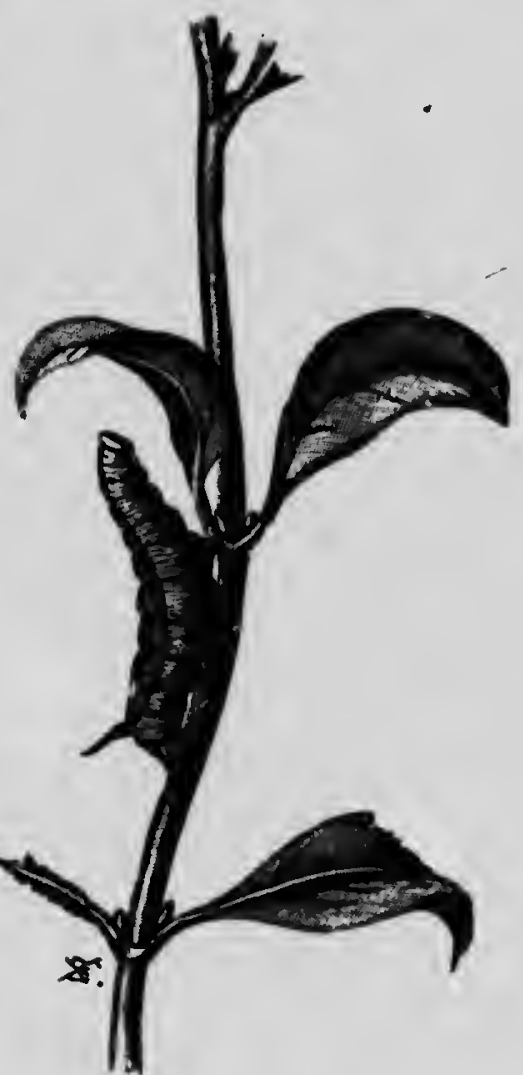

NO. 5.-CATERPILIAR OF THE BROAD - BORDERED BEE-HAWK TRYING TO LOOK ALARMING. his sides?" you will ask. "Surely they must make him an easy mark for birds?" Not at all : please notice that they run obliquely. There is method 
in that obliquity. When the caterpillar is smaller, he lurks unseen on the under side of the leaves, and this pattern of oblique purplish lines exactly

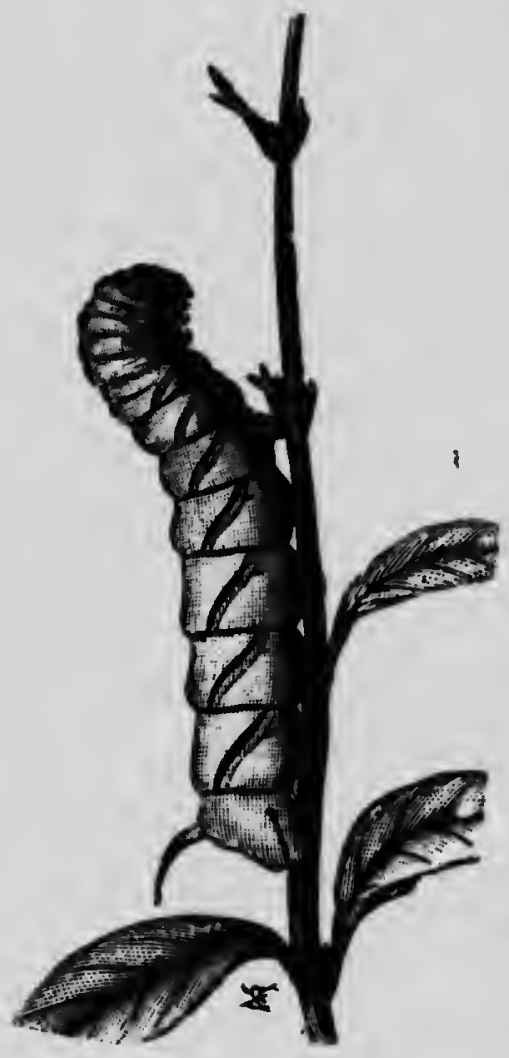

NO. 6. - FUI.L-GROWN CATERPILLAR OF THE PRIVET IIAWK - MOTH, SIMILARLY OCCUPIED. imitates the general effect of the shadows cast by the ribs - so much so, that if you look for him on a privet tree in spring, I doubt whether you will find him till I point him out to you. Even when he waxes fat and full fed, the purple stripes still aid him more or less by breaking up the large green surface into smaller areas, as Professor Poulton has well noticed. He harmonises better so with the broken masses of the leaves about him. Then again, when the time arrives for him to turn into a chrysalis, he descends to the ground, which, under a thicklyleaved privet bush, is most often brown. So, just as he is coming of age and reaching the proper moment for migration, his back all at once begins to turn brown, in order that he may be less observed as he walks about 
on the stem; while by the time he is quite ready to take to the earth he has grown brown all over, thus matching the soil in which he has next to bury himself. You could hardly have a better example of the sort of colour-change which often accompanies altered habits of living.

In the illustration, however, you see this really harmless and undefended grub in the act of trying to pretend he is poisonous. He is now mature, and the stripes on his sides stand out conspicuously as he walks on the stem. A sparrow threatens him. $\mathrm{He}$ retorts by showing fight-fallaciously and deceptively, for he has nothing to fight with. $\mathrm{He}$ lifts his head with an aggressive air, and throws himself about from side to side, as if he knew he could bite, and meant to do it. He also lashes his tail in pretended anger-"I would have you to know, Sir Bird, I am not to be trifled with!" The empty demonstration usually succeeds: the sparrow gets alarmed and believes he means it. This policy is, in essence, that commonly known as "spirited": it consists in trying to frighten your enemy instead of fighting him.

The oddly-marked caterpillar of the Puss Moth carries the same plan of campaign to a much more artistic pitch. This very quaint insect is common on willows and poplars in England, and is on the whole protectively coloured. Black at first, it looks like a mere speck or spot on the leaf; as it grows, it becomes gradually greener, relieved with broad purple patches on the back, which produce the effect of lines and shadows. When quite full- 
46 IN NATURE'S WORKSHOP

grown, as seen in No. 7 , the adult caterpillar generally rests at ease on the twigs of the willow tree. Our illustration shows it in this final stage of its larval life, just taking alarm and humping its back

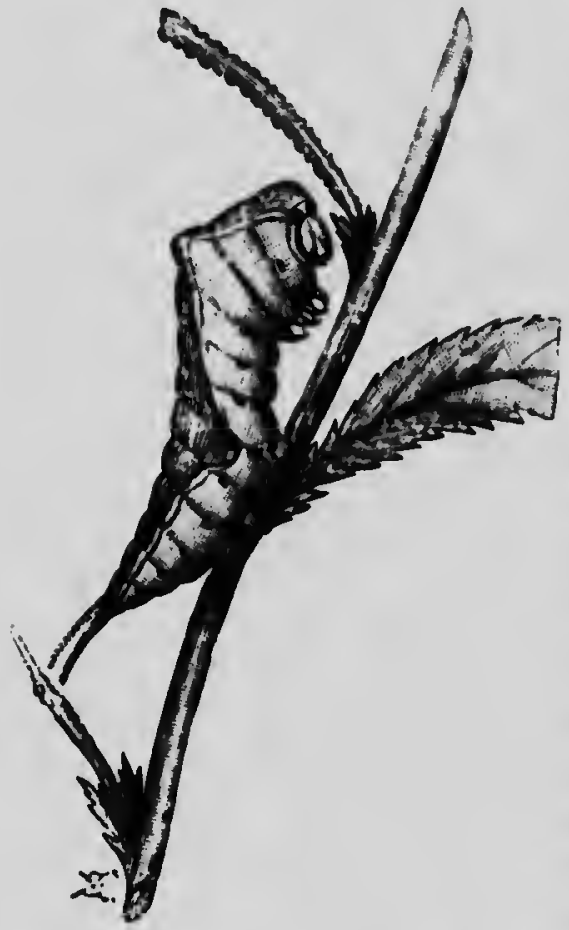

NO. 7.-CATERIILIAR OF THE PUSS MO'TH PREPARING; FOR ACTION. at the approach of sonie bird or other enemy. If the alarm continues, it goes through a most curious series of evolutions, admirably shown by Mr. Enock in No. 8. Here, the little beast is altogether on the defensive : it withdraws its head into the first ring of the body, and inflates the margin, which is bright red in colour. Two black spots, which are not really eyes, but which look absurdly eye-like, now give it a grotesque and terrifying appearance. In fact, the inflated ring resembles a hideous grinning mask, and gives the impression of a face with eyes, nose, and mouth, like that of some uncanny creeping creature. But the apparent face is not a face at all : it is artfully made up of lines and spots 
on the skin of the body. At the same time that the caterpillar thus assumes its mask, it stands on its eight hind legs as erect as it can, and whips out two pink bristles or tentacles from the forked prongs at the end of its tail-you can see them in the picture. It then bends forward the tail, and brandishes or waves about these pink bristles over its false head, so as to present altogether a most gruesome aspect. Indeed, even $\mathrm{Mr}$.

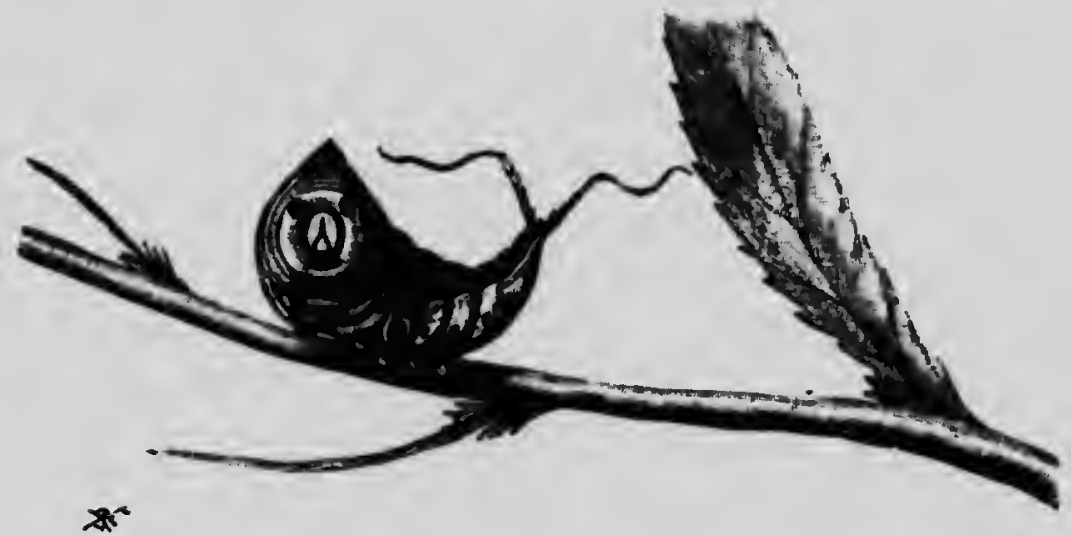

NO. 8. -THE SAME CATERPILLAR TEKRIFYING AN ENEMY.

Enock's vigorous sketch of the little brute in its tragic moments does not quite convey the full effect of its acting in the absence of colour: for the bright red margin and the swishing pink switches add not a little to the telling smirk and black goggle-eyes of the mask-like face thus produced in terrorem.

That is not all, either. The Puss Moth caterpillar has a rapid trick of facing about abruptly in the 
direction of the enemy as if it meant to bite : and this trick is always most disconcerting. If ever so lightly touched, it instantly assumes the terrifying attitude, and presents its pretended face to the astonished aggressor. From a harmless caterpillar it becomes all at once a raging bulldog. Touch it on the other side, and it faces round like lightning in the opposite direction. Professor Poulton tried the effect of its grimace on a marmoset, and found the marmoset was afraid to touch the mysterious creature. We are not marmosets, but I notice that most human beings recoil instinctively from a Puss Moth caterpillar when it assumes its mask. Even if you know it is harm!ess, there is something very alarming in its rapid twists and turns, and in the persistent way in which it grins and spits at you.

Really spits, too; for the insect has a gland in its head which ejects, at need, an irritating fluid. If this fluid gets into your eyes, they smart most unpleasantly. It contains formic acid, and is strong enough to be exceedingly stinging and painful. The discharge repels lizards, and probably also birds, who are among the chief enemies of this as of other caterpillars.

The deadliest foe of the Puss Moth larva, however, is the ichneumon-fly, a parasitic creature, which lays its eggs in living caterpillars, and lets its grubs hatch out inside them, so as to devuur the host from within in the most ruthless fashion. There are many kinds of ichneumon-fly, some of them very minute : the one which attacks the Puss 


\section{False Pretences}

Moth in its larval stage is a comparatively big one. The fly lays its eggs behind the caterpillar's head, where the victim is powerless to dislodge them. In all probability the defensive attitude and the shower of formic acid are chiefly of use against these parasitic foes : for when an ichneumon-fly appears, the caterpillar assumes his "terrifying" attitude the moment it touches him, and faces full round to the foe with his false mask inflated. A very small quantity of the formic acid Professor Poulton found sufficient to kill an ichneumon: and there can be little doubt that this is its main object.

The last of these "bluffing" caterpillars with which I shall deal here is that of the Lobster Moth. In No. 9 you see a couple of these quaint and unwieldy creatures "demonstrating" before an enemy, as if he were the Sultan. The Lobster Moth in its larval stage frequents beech-trees, and you will see in the illustration that the two represented are on a twig of beech. When at rest, the caterpillar resembles a curled and withered beechleaf, and by this unconscious mimicry escapes detection. But when discovered and roused to battle, oh, then he imitates the action of the spider. He holds up his short front legs in a menacing attitude, so as to suggest a pair of frightful gaping jaws: the four long legs behind these he keeps wide apart, and makes them quiver with rage in the most alarming pantomimic indignation. His tail he curns topsy-turvy over his head like a scorpion; while the forked appendages at its end seem like frightful stings, with which he is just about to 
inflict condign punishment on whoever has dared to disturh his quiet. But it is all mere brag, though the whole effect is extremely terrifying. The performance does not, indeed, mimic any particular venomous beast, but it suggests most appalling and

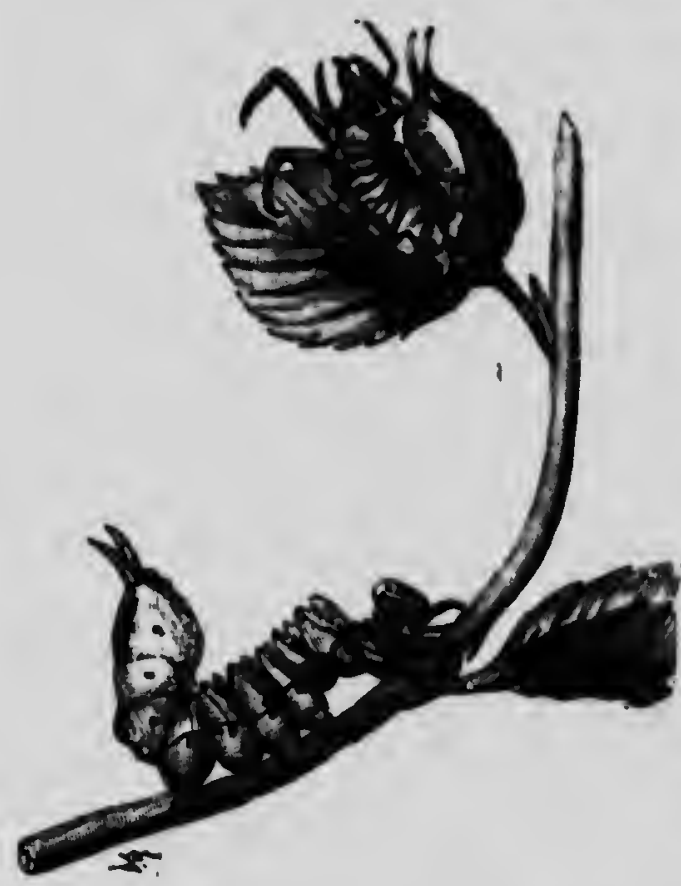

NO. 9. - CATERPIIJARS OF TIIE LOBSTER MOTH DEMONSTRATING IN FORCE. BE. FORE THE HOSTIIE RATTAI.IONS. paralysing pussibilities. Many of these yueer attitucles, indeed, owe their impressiveness just to their grotesque simulation of one knows not quite what : they are not definite and special, they are worse than that ; they appeal to the imagination. And if only you reflect how afraid we often feel of the most harmless insects, merely because they look frightful, you will readily Inderstand that such vague appeals to the imagination inay be far more effectual than any real sting could ever be. We dread the unknown even more than the painful.

The funniest of all these false pretences, however, 
is one which Hermann Miller, I believe, wals the first to point out in this same Lobster Moth citerpillar. When very much bothered by iclineumon. flies (to whose attacks it is particularly exposed), this bristling beast displays, for the first time, two black patches on its side, till then concealed by a triangular flap. Now, these patches closely resemble the sort of wound made by the iclineumon when it deposits its egggs, so it is probable that they serve to take in the assailant, who is thus led to think that another fly of her own kind has been before her, and, therefore, that it is no use laying her eggs where a previous parasite is already in possession. There would not be enough Lobster Moth to feed two hungry ichneumon families. In fact, the caterpillar first begins by bluffing, and says, "If you touch me, I bite!" then, finding the bluff unsuccessful, it further pretends to throw up the sponge, and cries out with a bounce: "Oh, if egglaying is your game, that's no good: I'm already occupied !" For a combination of wiles, this crafty double game probably "licks creation."

If the defenders are so cunning, however, the attackers can sometimes turn the tables upon them. Animals that hunt often disguise themselves, in order to avoid the notice of the prey, and so steal unobserved upon their victims. Such tactics are like those of the Kaffirs, who cut bits of bush, and then creep up slowly, slowly behind them, under cover of the branches, upon the gnus or antelopes which they wish to slaughter. $I_{1}$ No. 1o we have one example of this method of 
hunting or stalking, as pursued by the intelligent English grass-spider. All spiders, of course, have eight legs, four on each side; but in most of the class,

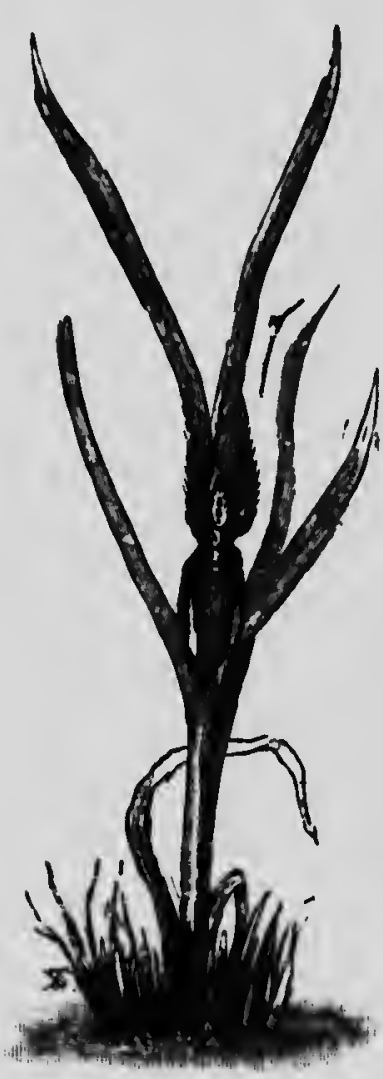

NO. IO.-GRASS-SPII)ER, IN AMIBUSII FOR FIIES.

the various pairs of legs are evenly distributed, so as to lie about the body in a rougl circle or something like it. The grass-spider, however, has his own views on this important matter. His form and attitude are quite peculiar. He lies in wait for his prey on the open, crouched against a sten of grass, with his two front pairs of legs extended before him, and his back pair behind, in an arrangement which is rather linear than circular. This position makes him almost invisible-much more invisible in real life, indeed, than you see him in the drawing; for if he were represented as inconspicuous as he looks you would say there was no spider there at all, only a naked grassstem. The delusion is heightened by his lines and colours: he is mostly green or greenish, with narrow black or brown stripes which run more or less up and down his body, instead of 
cross-wise as usual, so that they harmonise beautifully with the up-and-down lines of the blades and stem in the tuft which he inhabits. When he is pressed close against a bent of grass, on the look-out for flies; it is almost impossible for the quickest eye to distinguish him. Flies come near, never suspecting the presence of their hereditary foe; as soon as they are close to him, the grass-spider rushes out with a clash and secures them. His jaws are among the most terrible in all his terrible race: they are large and widespreading, with two rows of teeth on either side, and a pair of long $f_{2}$ is of truly formidable proportions.

In other ways, also, this particular spider is a clever fellow, for he lives near water; but when the rains are heavy and there is likely to be a flood, he shifts his quarters higher up the ground, and so escapes impending inundation.

Deceptions and false pretences of this sort are somewhat less common among plants than among animals; but still, they occur, and that not infrequently. "What? Plants deceive?" you cry. "The innocent little flowers? How can they do it ? Surely that is impossible!" By no means. I have watched plant life pretty closely for a good many years now, and every year the conviction is forced upon me more and more profoundly that whatever animals do, plants do almost equally. There is no vile trick or ruse or stratagem that they cannot imitate: no base deception that they will not practise. They lie 
and steal with the worst; they hold out false baits

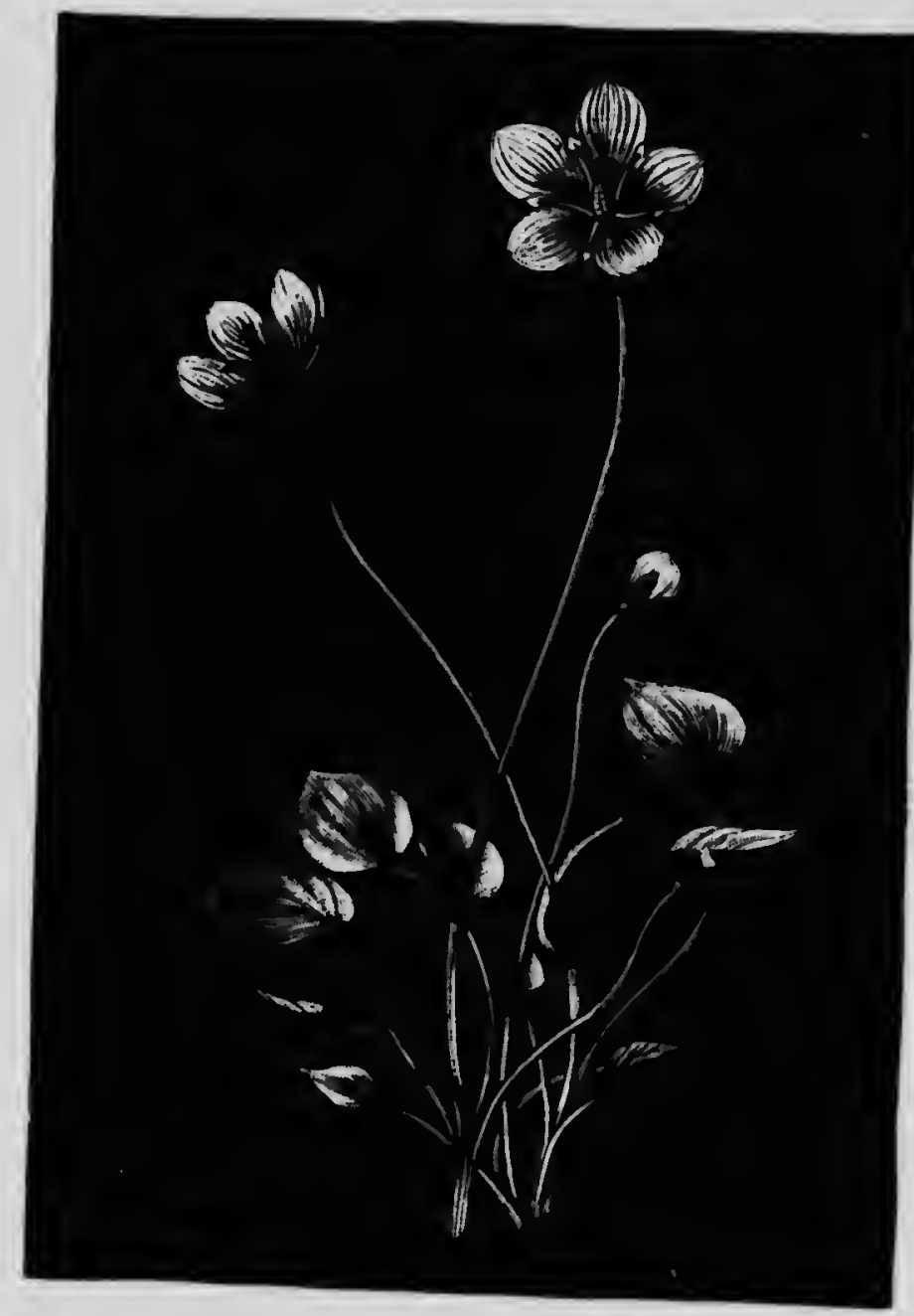

NO. II.-GKASS OF I'ARNASSUS, DISPLAYING ANI) AIVERTISING ITS IMITATION HUNEY.

for deluded insects, and hide real fly-traps with honeyed words and sweet secretions. 
As a good illustration among English plants, look at the Grass of Parnassus, that beautiful, dishonest bog-herb, with glossy-green leaves and pure white blossoms, which is considered the especial guerdon of poets. I found a whole nest of it once in a swamp near Cromer, and earried off a bunch of the lovely flowers as an appropriate offering to Mr. Swinburne who was stopping it Sidestrand. Yet this poet's flower, dainty and delicate as it is-you see in No. I I its counterfeit presentment-is not ashamed to deceive the poor bees and flies in a way which the Heathen Chinee would have considered unsportsmanlike. It is a sham, a commercial sham of the worst type. It lives for the most part on wet moors among mountains, or else in the boggy hollows between blown sarit-hills by the sea : and when its milkwhite flowers star the ground in such spots, it forms one of the loveliest ornaments of our English flora. But trust it not, oh butterfly: it is fooling thee! From a distance it looks as if it were full of honey; it advertises well: but at close quarters 'tis a wooden nutmeg; it turns out to be nothing better than an arrant humbug.

The deception is managed in this disgraceful fashion. Inside each petal lies a curious ten- or twelve-fingered organ, which is in reality an abortive stamen. No. I2 shows you one such petal removed, with the false honey-glands drawn on at larger scale than in the other illustration. The ten-fingered stamen bears at its tip a number of translucent yellow drops, which look like pure 
nectar. But they are nothing of the kind; I regret to say, they are solid-solid-a commercial falsehood. They glisten like drops : but they are mere glassy imitations; and they are put there with intent to deceive, in order to attract flies and other insects, which come to quaff the supposed nectar, and so unwittingly fertilise the seeds, while they are muddling about perplexed among the pretended honey-

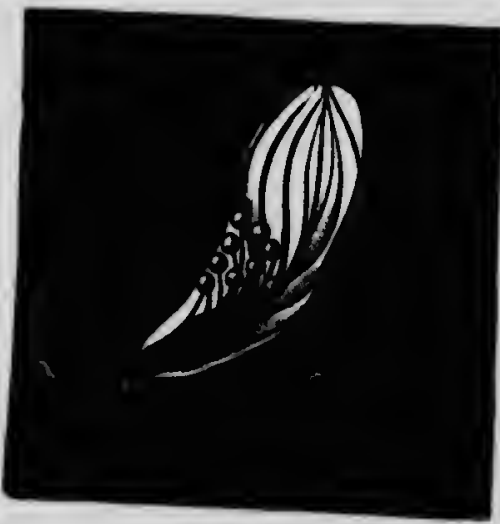

NO. I2.-A SINGI.E PETAL, TU SHOW TIE CHARACTER OF THE SHAM HONEY. nassus, mendacious the Grass of Parglands, without getting paid one sip for their toil and trouble. This is, of course, a flagrant case of obtaining services under false pretences; it deserves fourteen days' without the option of a fine. As a rule, in similar cases, the flies are rewarded for their kind offices as carriers by the merited wage of a drop of honey. But the Grass of Para specially fine quantity and quality of nectar, while in reality it offers oilly a hard, glassy knob with nothing in it. This pays the plant, of course, because the blossoms do not have to go on producing honey fresh and fresh; a mere inexpensive show does just as well as the real article: "Our customers like it!" but the language of the flies when they discover the fraud is something just awful. 
Nor is this by any means a solitary example of plant depravity. The whole group of pitcherplants, for instance, cruelly manure themselves by means of living insects in the most treacherous fashion. These lovely and wicked plants live, without exception, in wet and boggy soil, where they cannot get enough animal matter for manure in the ordinary way by the roots : so they lay themselves out instead to capture and absorb the tissues of insects. For this horrid purpose they twist their leaves into deep pitchers which catch and hold the rain-water, and so form reservoirs to drown their prey. Then they entice insects by bright colours to their traps, and allure them to enter by secreting honey at the top of the pitcher. Hairs point downward inside; these allow the flies to walk on to their fate, bribed as they go by lines of nectar: but if they try to return, ah, then they find their mistake: the hairs prevent them, after the fashion of a lobster-pot. Thus they walk on and on till they reach the water, when they are swamped and clotted in a decaying mass, from which the treacherous plant draws manure at last for its own purposes. The pitchers are thus at once traps to catch animals, and stomachs to digest them.

Another and still odder case of deceptiveness in plants is shown by a curious group of South African flowers, the Hydnoras and Stapelias. These queer and malodorous herbs have very large and rather handsome but fleshy blossoms, an inch or two across, dappled and spotted just like decaying 
meat. They live in the dry and almost desert region, where carrion-flies abound. Such flies lay their eggs and hatch out their grubs for the most part in half-eaten carcasses of antelopes or smaller animals killed and in part devoured by lions and other beasts of prev. So the flowers have taken to imitating dead meat. They are a lurid red in colour, with livid livery patches, and they have a strong and unpleasant smell of decaying aninal matter. The flies, deceived by the scent, flock to them to lay their eggs, and in so doing carry out the real object of the plant by fertilising the blossoms. But, of course, the whole thing is a vile sham ; for when the 'maggots hatch out, the flower has died, and there is no food for them, so they perish of starvation. Dr. Blackmore, of Salisbury, once gave me some of these curious plants and flowers : I noticed that in the sunlight, where they smelt just like decomposing meat, they attracted dozens of bluebottle flies and other carrion insects.

Protective resemblance also occurs among plants ; for in the same dry South African region, where every green thing gets nibbled down in the rainless season, certain ice-plants and milk-weeds have acquired the trick of forming tubers or stems exactly like the pebbles among which they grow : so that when the leaves die down in the dry weather, the tuber is not distinguishable from the stones all round it. Such tubers are really reservoirs of living material designed to carry the life of the plant over the dead season : as soon as rain comes 
again, they put forth fresh green leaves at once, and grow on after their sleep as if nothing had happened. Even terrifying attitudes are not unknown in the vegetable world : for one of the uses of the movements in the Sensitive Plant is almost certainly to frighten animals. Browsing creatures that come near the bushes in their native woods see the leaves shrink back and curl up when touched, and are ifraid to eat a tree that lias so evidently a spirit in it. The Squirting Cucumber of the Mediterranean, again, alarms goats and cattle by discharging its ripe fruits explosively in their faces the moment the stem is touched. In this case the primary object is no doubt the clispersal of the seeds, which squirt out elastically as the fruit jumps off; but to frighten browsing enemies is a secondary advantage. There can be no question as to the reality of the plant's hostile intention, because the fruits also contain a pungent juice, which discharges itself at the same instant into the eyes of the assailant. As I have received a volley of this irritating licyuid more than once in my own face (in the pursuit of science) I can testify personally on the best of evidence that it is distinctly painful. The tactics of the Syuirting Cucumber in first frightening :- and then injecting acrid juice into your eyes, are thus exactly similar to the plan of action pursued by the angry larva of the Puss Moth. 


\section{III}

\section{PLANTS THAT GO TO SLEEP}

$D$ LAN'T'S sleep almost as truly as animals. To be sure, their sleep is a trifle less obtrusive -plants never snore: but it is quite real for all that, and its reality can be shown, as I hope to show it here, in a great many instances. Perhaps the best-marked form of slumber in the vegetable world is that of the great winter rest, when so many species retire altogether under the sheltering soil, and there lie dormant, side by side with the slumbering animals. We all know that when winter approaches the sleek dormouse retreats into his snug nook, a woven nest of warm grasses just above the ground, where he dozes away the cold weather in a state of unconsciousness. Squirrels similarly hibernate in the holes of treetrunks; while bears grow fat in autumn, and after sleeping the winter through, emerge in April mere wasted shadows of their October selves. As to the cold-blooded animals, such as newts and lizards, snakes and adders, they dream away the chilly months, like the Seven Sleepers of Ephesus, coiled up in tangles among the banks and hedges. The lesser creatures-snails, and beetles, and grubs, and so forth-hibernate underground or conceal 


\section{Plants that go to Sleep}

themselves in the crannies of rocks and walls. But how does this long winter rest of animals differ, after all, from the winter rest of the crocus or the hyacinth, which withdraw all the living material from their leaves in autumn, and bury themselves inches deep in the soil in the shape of a bulb, till February rains or April suns tempt leaves and flowers out again? The whole vast class of bulbous and tuberous plants, indeed-the lilies, orchids, daffodils, narcissi, tulips, squills, blue-bélls, and snow-drops-are they not just hibernating creatures, which retire underground in autumn with the slugs and the queen wasps, to reappear in spring about the same time with the return to upper air of the moles, the tortoises, and the fritillary butterflies?

In the case of pond plants and pond animals, in particular, this close similarity of habit is especially evident. I have pointed out in "Flashlights on Nature" how the frogs and newts betake themselves to the depths before the surface freezes over; and how at the same time, when the whirligig beetles and the tapering pond-snails go below to hibernate, the buds of the frogbit and the growing shoots of the curled pondweed similarly detach their ends from the dying stems so as to bury themselves safely in the unfrozen mud of the oozy bottom. But it may not strike every one that much the same sort of winter sleep, for plants as for animals, is conımon on land too. When the squirrel retires into winter quarters in the trunk of the oak, where he has stored up his hoard of acorns 
against the dead season, does not the life of the oak itself do just the same thing? Does not the tree, too, fall asleep till the succeeding summer? I say "the life of the oak" in the most literal sense: for, remember, the protoplasin or living matler in the green leaves is withdrawn, before they fall, into the vital layer just below the bark; and there it sleeps away the winter, protected by its overcoat of corklike inaterial from the fierce frosts that would otherwise kill it. Indeed, it is only the dead skeleton of the leaf that drops on the ground: the life remairs and hides in the trunk or branches. The withered leaf is like the sloughed skin of the snake, the cast shell of the lobster, the empty pupa-case of the butterfly. Nay, more, one mity say roughly that almost all trees and shrubs or perennial herbs hibernate-become dormant in winter; but some of them conceal their living protoplasm in bulbs or tubers which they bury underground, while others store it in the sten or trunk, wrapped warmly up in a thick vegetible blanket.

Even evergreens sleep, though not quite so openly. Take two familiar contrasted cases. The Scotch fir and the larch are closely related: but the larch, a native of wind-swept heights in Central Europe and Northern Asia, would have its slender branches broken and its swaying trunk snapped by the weight of snow which they would be compelled to sustain if the leaves persisted on the tree through the winter, besicles running a good chince of being blown down in every big storm; so it has acquired 


\section{Plants that go to Slefep}

the habit (very unusual among conifers) of shedding its cast-off leaves in autumn like the oak and the elm, after it has hidden a way their vital contents in the living layer. In this way, it comparatively escapes the heavy load of snow it must otherwise bear, and also presents at far sinaller expanse of resisting surface to the wintry Tyrolese and Siberian tempests. The Scotch fir, on the other hand, a stouter tree with stronger branches, can enclure the heavy load of snow, which it shifts often enough as the wind strikes it ; so it has evergreen leaves, like most of its class : but these needle-like leaves are thick-skinned and covered with a protective glassy glaze which effectually guards the living matter within from the frosts of January. Large-leaved evergreens, like the common laurel and the rhododendron, have a similar glassy layer to protect their foliage; but they are more southern types; our northern winter tries them often, and in severe seasons they get terribly frost-bitten. Even these evergreens themselves thus sleep, though unobtrusively: that is to say, their life is really suspended more or less during the winter months, though the living material is then exposed in the leaves, instead of being withdrawn into the bark as in the larcl, or into a bulb or tuber as in the tulip and the crocus.

But besides this yearly winter sleep or hibermation a great many plants also sleep every night : in other words, they suspend more or less their usual activities, and devote themselves to rest and recuperation. For what do we mean by sleep? Well, Mr. Herbert Spencer has admirably defined it as 
64 IN NATURE'S WORKSHOP

"the period when repair predominates nver waste." During our waking times, we walk, work, wasteuse up the living inaterial of the hody: in our sleeping hours we rebuild and restore it. Now this is not quite true to the same extent of plants; though even plants in certain senses grow more by night than by clay. Yet it is toue in the main

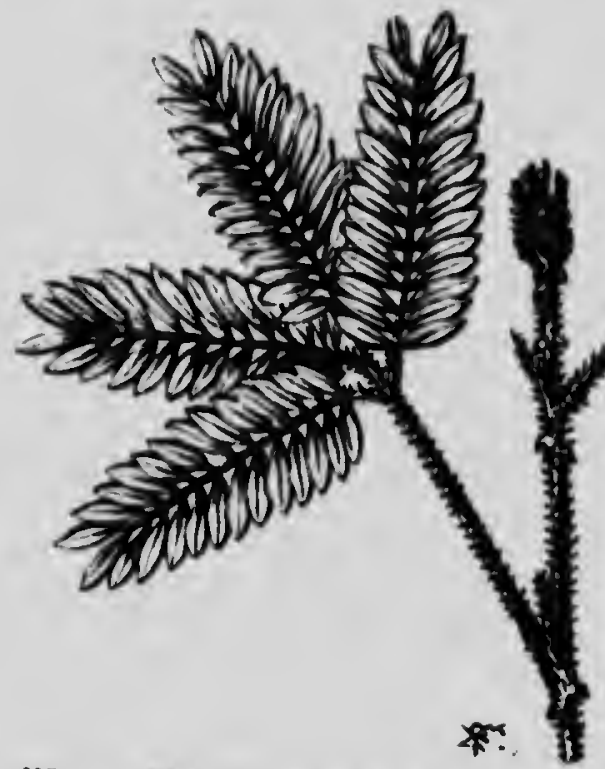

NO. 1.- BRANCII OF MIMOSA, TIIE LEAF AWAKE. that plants suspend in their sleeping hours a great many functions which they carry on while they wake; and that the sleeping time is mostly devoted to repair and growth, not to active intercourse with external nature. By day, plants eat : by night, they utilise and arrange what they have eaten.

My illustration No. I shows the leaf of a mimosa bush in its waking moments. You would call it at first sight rather a branch than a leaf, no doubt; but in that you would be mistaken : it is really one much-divided leaf, though not by any means a simple one; and when it falls off, it falls off from 
the base like a single structure. It is, in point of fact, a very compound leaf, split up into four main parts, each of which is again subdivided into many opposite pairs of leaflets. Now, in No. I here, the leaf is seen as it looks when expanded in the broad daylight: it is hard at work eating and siliking for the benefit of the plant: it alssorb., h: $11 \mathrm{il}$ hundred little mouths or leaflets, the 'arlunus i i, of the surrounding air, which it comverts, m, ln the influence of sunlight, into suitable plinn-ionc. il thus works in the daylight just as trilly is tilc noisy bee works when it gathers honey : Just ats truly ats the ant works when it collects dead meat and scrap of ant-provender: just as truly as the kinifioher works when it darts down upon the trout, or is the Hy-catcher works when it swoops upon the flies that flit about in the garden. All these are diurnal plants and animals; they utilise, as Dr. Watts succinctly puts it, "each shining hour" : and they rest when night comes from their daily labours. For, remember, a plant can only eat its proper food, carbonic acid, while the light falls upon it; at night it must sleep, digest, and distribute what it has eaten.

No. 2 shows us a larger branch of tine same mimosa bush, with two such compound leaves seen as they look when folded up in sleep cluring the dark hours of the evening. Not only the famous and well-known Sensitive Plant sleeps like this, but also many other kinds of nimosa and acacia much cultivated in our greenhouses. It is a pretty sight to see them falling gradually asleep- 
dozing off, if I may be allowed that familiar expression. First of all the opposite pairs of leaflets fold together upward, so as to present a single combined

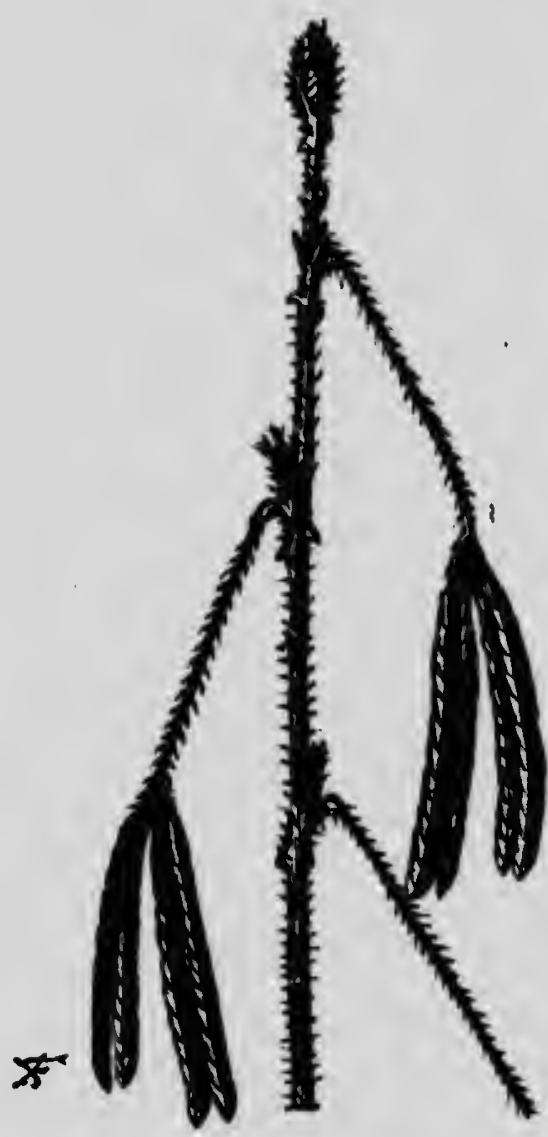

NO. 2-BKANCH OF MIMOSA

LEAVES FAST ISLEEP. surface, like that of a hinged tablet when you shut its halves together. Then the four main leafstalks on which the leaflets are fixed sink slowly down like a sleepy child, and double themselves away out of the range of danger. Last of all, the principil leaf-stalk or main midrib of the whole branchlike leaf itself droops and drops drowsily, and the entire structure hangs limp, as if dead, against the branch that supports it. In No. 2 you can see a pair of such four-branched leaves sound asleep in their pendent attitude. Each of these, when expanded, would resemble the open and active leaf in No. 1. You can see for yourself that the waking leaf is obviously equipped for work and action, while the sleeping leaves are quite as obviously arranged for rest and recuperation. You can also observe in 
No. 2 the main leaf-stalk or mid-rib of a third leaf, which is hanging down unseen, out of the field of the drawing.

The machinery for producing these curious sleepmovements is situated in certain very irritable little knobs at the base of the leaf-stalk, one of which you can observe close to the stem in the case of the lowest leaf-stalk (with its leaf unseen) in No. 2. The mechanism acts much like a nervous system : it governs the movements and attitudes of the leaf by night or day. In the true Sensitive Plants, the leaflets fold up out of harm's way when touched. In most mimosas and acacias, however, they only fold at night, or in very cold or dark weather. Their folding is partly effected for the sake of warmth, because they then expose only one surface of each leaf; it may be compared to the way in which mice and other animals curl up in their nests, or to the habit of snakes in lying coiled up in holes, knotted together one with the other. But it is partly also done for physiological reasons : the plant rebuilds itself in sleep just as truly as the animal, and this posture seems to suit its growing and redistributing activities.

In No. 3 we have a branch of that common and beautiful little English wild-flower, the wood-sorrel. The plant is here represented wide awake in the daytime, its blossom expanded to court the insects that fertilise it, and its leaves wide open, drinking in its gaseous food as fast as they can drink it. Woodsorrel is a tender and thin-textured spring herb; a chill is therefore highly prejudicial to its health : 
without being exactly delicate-for in a certain sense wood-sorrel may even be called hardy-it feels the need for taking care of itself. Severe cold nips it up: even gentle frosts have a bad effect upon it. But the wise herb has arranged against such adverse chances by the peculiar disposition of its dainty wan foliage. The leaves

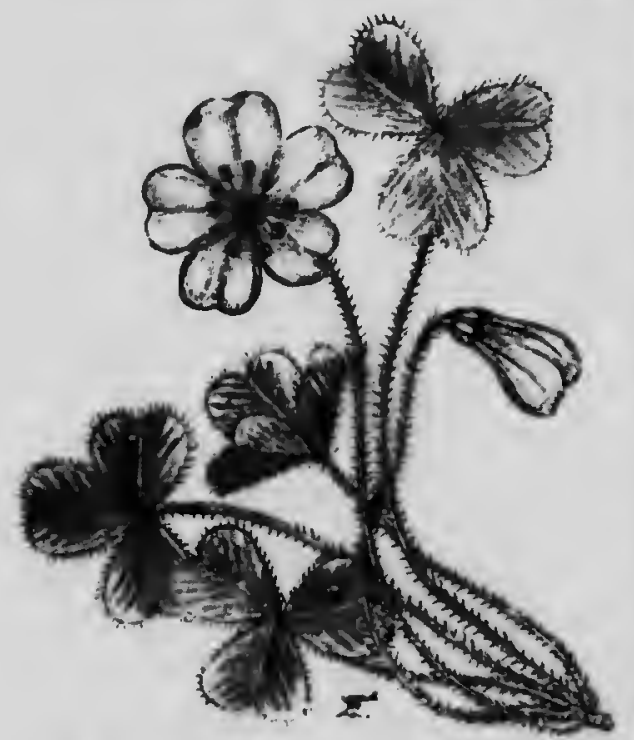

NO. 3.-WOOD-SORRRI, ; THE FI.UWER AND LEAVES BOTH AWAKE. the warmth they expand to the utmost, as you see are composed of throw leaflets each, and even at a casual glance, something ibout their midribs might sugryest to you the idea that they were intended for folding. And su they are. They fold quaintly downward - not one against the other, as in the mimosa, but half of each leaflet against the other half. In in No. 3 ; when night falls they fall too, as you can observe in No. 4, where both leaves and flowers are fast asleep, resting after the arduous labours of the day in a profound slumber.

If you consider what the parts are doing in each case you will realise that day differs from night for 
the plant exictly as it differs for the animal-the one being a period of direct intercourse with external nature, and the other a period of repose, growth, and internal restoration. For during the daytime; the wood-sorrel swallows or sucks in with its leaves such carbonic acid as the wind brings its way, and then exposes it in the full sunlight to be assimilated and rendered useful : but by night it folds its leaves, just as the shopkeeper puts up his shutters or the mill stops work; it keeps them warm by contact with one anoher; and it begins to use up the material it has eaten for growth and sevelopment. Similariy with the danty white lilacstreaked flowers: during the day they open their slender

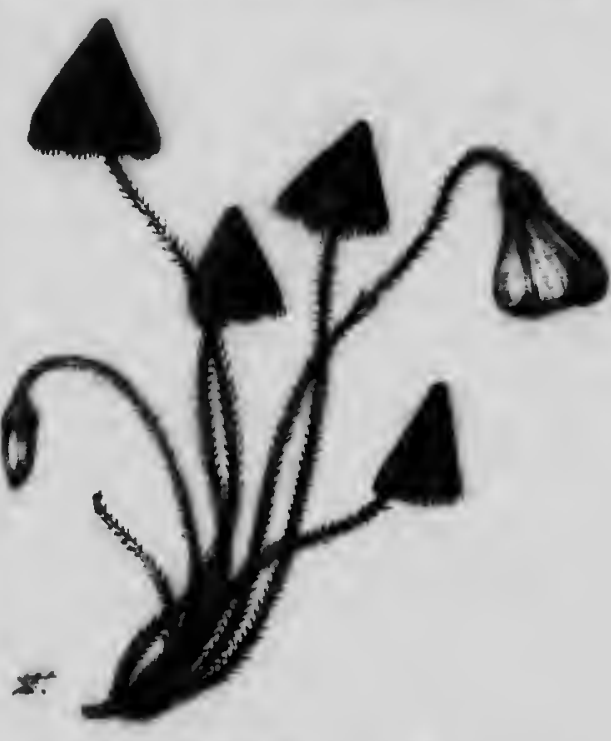

NO. 4.-WOOD-SORREL; THE FLOWER ANU LEAVES BOTH ASt EEP.

petals, hold up their heads, and receive the visits of the insects upon whom they depend for fertilisation: but when night comes, and the insects have gone to bed, it is no use hanging out the sign any longer, so to speak-for the petals are just sign-boards to attract the eyes of the insect customers. Various misfortunes might happen to the 
flower in the cold spring nights, if it still kept open. The frost might nip up and wilt the petals : rain might fall and wash away the honey or the pollen: wind might disperse the fruitful golden grains, intended for the seed-vessels of sister blossoms. So the prudent plant imitates the little beasts which curl themselves up in their holes: it makes the flower hang its head and close its petals, so as to imprison warm air within its bell-shaped hollow. In this position, it is safest from rain, which can neither fill the cup so as to break the stem nor dilute the honey, nor waste the pollen. Thus, all night long, the wood-sorrel suspends its business intercourse with the outer world, and retires upon itself for rest and recuperation; when morning comes again, it opens its leaflets to drink in the air and the sun, and lifts its flowers once more to attract the insects. Alike for warmth, for safety, and for economy, it sleeps by night; it wakes by day, and engages actively in the business of its existence.

I may add that we know otherwise how particularly necessary is heat to the wood-sorrel. If you examine the under-side of the winter leaves-I mean those few old leaves which manige to struggle on from the preceding year through an English January - you will find that they are distinctly reddish or purple. Now, chemists have shown us that this red or purple colouring matter which is spread on the under-side of the foliage in many plants is a substance with a curious power of catching the remnant of such light-rays 
as pass unused through the green cells of the leaf, and transforming them into heat-rays. To put it plainly, the red pigment is a warmth-catcher, a machine for transmuting light into heat. You therefore find it most often on the under-side of many early spring plants, which naturally need all the heat they can get, as well as on-aquatic herbs like the water-lilies, whose under-surface is constantly chilled (even in summer) by contact with the cold water. For example, the cyclamens so commonly grown in drawing-room windows in winter have bright purple under-sides to their leaves, because they grow and flower in the coldest months: so has an exotic wood-sorrel, which is a favourite pot-plant with cottagers, and which goes to sleep every night of its life, even more conspicuously than our wild English species. In every case where you light upon purple or red colouring matter abundantly present in leaves or shoots (as in sprouting peonies, and spring growth of rose-bushes), you may at least suspect that warmth is its principal purpose. Nature does nothing in vain : there is always a reason in the merest detail.

But you may ask, "Why do not all leaves equally go to sleep at night? Why have you thus to pick out a few select examples?" The answer is, all leaves do ; but some of them sleep more conspicuously and visibly than others. The cases in which you can see that they sleep are those of plants with thin and delicate foliage, where the leaves or leaflets gain mutual protection against 
radiation and cold by putting themselves, so to speak, two layers thick. Very dainty spring foliage shows sleep most obviously : very thick and coarse leaves, like those of the cyclamen, the rhododendron, the Siberian saxifrage, or the common laurel, sleep without folding; they have warmth enough or glassy covering enough to resist injury. Here again we can see the allalogy between the nightly and the winter sleep: thin-leaved trees shed their leaves in autumn: thick-leaved kinds, such as laurustinus, spruce-fir, and laurel, retain them unshed through the entire winter.

The sleep of flowers is even more conspicuous and more readily aroused than the sleep of leaves. Blossoms are delicate and inuch exposed. Foliage for the most part sleeps by night only : but flowers take casual naps now and again when danger looms in the daytime. This is only what one might expect ; for the flower is usually the part of the plant which does the most varied external business and holds the most specialised intercourse with the rest of nature. The leaf has relations with the sun and the air alone; but the flower has to attract and satisfy all sorts of fastidious and capricious insect assistants: it has to produce pollen, honey, and seeds : it has to provide for its own fertilisation and that of its neighbours. Hence, it may have to wake or sleep in accordance with the convenience of the outer world: just as a railway porter or a club servant must get up and go to bed, not when he chooses himself, hut when
his employers choose to make him. 'The rule with 
flowers is this : they open the shop when customers are most likely to drop in ; they shut it when there is nobody about and when valuable goods like honey and pollen run a risk of getting damaged.

The purple crocus, illustrated in its working hours in No. 5, is an carly spring flower which has to open under considerable .disadvantages. It lays by material during the previous summer in an underground bulb, sleeps the winter through, and pushes up its head in the very early spring, at a time when frost and snow are still extremely probable. All such early spring plants, I need scarcely say, are naturally hardy: they also ivrap themselves up warm in blankets and overcoats. The crocus bud when it first emerges is folded tight (like an Indian papoose or all Italian bambino) in a neat and commodious papery coverlet : it only peeps out

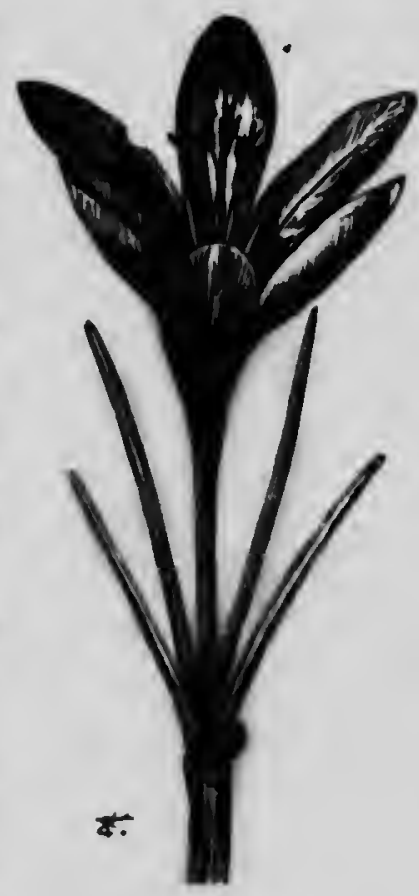

NO. 5- - PURPLE CROCUS, OPEN IN SUNSHINE. of its close-fitting mummy-case when the weather promises a chance of successful flowering. A little break of warmth in February or March, however, suffices for its purpose. It will unfold its purple corolla gaily in the sun, and flaunt its golden-yellow 
stigma in the midst of the blue cup to allure its winged allies to the store of honey.

These allies are all of them bees, dozens of whom venture out on the prowl on sunny days through the whole winter. It is for them that the gorse hangs out its nutty-scented flowers : for them that the crocuses, golden or purple, expand their chalices. As long as the sun shines, in spite of cold east winds, the bees bury themselves deep in the tempting blossoms, dust their hairy thighs with quantities of pollen, and rub it off against the feathery and sticky stigmas of the next flower they visit. But spring sunshine is not a joy to count upon. Great white clouds roll up and obscure the clear blue sky; a cold wind accompanies them; the bees hurry off, full-laden, to their hives or their underground nests; rain, sleet, or snow threatens. The prudent crocus perceives that all chance of business is over for the present, and, like a booth-keeper at a fair, when the crowd lias gone, it proceeds to shut up its shop and take care of its merchandise. And it is well advised, for its shape renders it peculiarly liable to damage from rain or sleet when open; so it closes its corolla, as you see in No. 6, making the folded lobes do duty as an umbrella. If rain or snow comes, it is thus effectually protected : the pollen is not washed away, nor is the large and fleshy stigma ruined. You will find these tactics common among cup-shaped or chalice-shaped flowers like the crocus and the tulip: they never occur among bell-shaped hanging flowers, like 
the harebell or the wild hyacinth, where the whole blossom, being turned downward and entered from below, forms a perpetual umbrella to guard its own pollen and its own honey from stress of weather. These last are a higher and more evolved type, belonging for the most part to very advanced and progressive families.

Most spring flowers, however, in their anxiety to attract the few insect visitors who are about at that treacherous period of the year, keep open door, and spread their blossoms, cup - like, upwarcl. Examples, other than the crocus and the tulip, are the winter aconite, the buttercup, the wood-anemone, the Alpine gentians, the globe-flower, and the hepatica. Most of these early flowers shut up for every passing cloud, and open again for every gleam

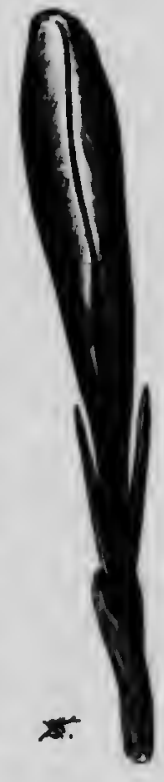

No 6. -A CLOUd PASSES; THE: Crocus closes tU PROTECT ITS POI.LEN. of sunshine. They are hard at work all the time, opening and shutting as the weather changes. On a typical April day I have often noticed the yellow crocuses expand and close half-a-dozen times over.

A great many flowers which have the honey 
and pollen openly exposed in this cup-like way are much given to closing, even in summer, for every cloud that passes, because they are naturally so afraid of being spoiled by a wetting. This is particularly the case with the wheel-shaped forms -those, I mean, with open flat saucers like the

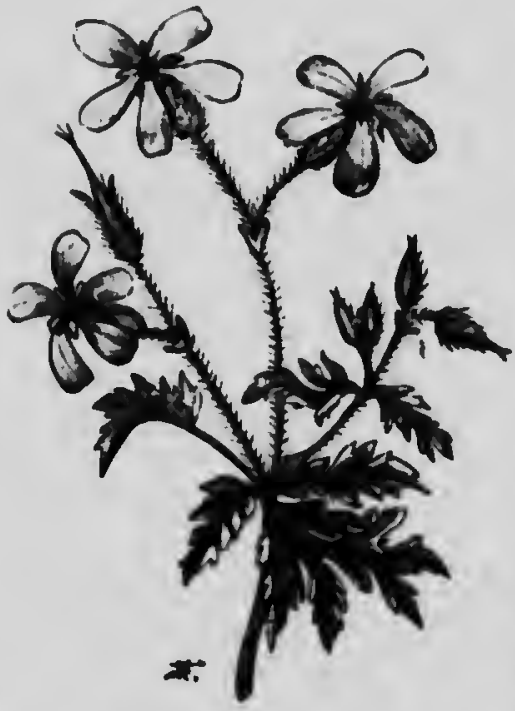

NO. 7. - WII.D GERANIUM, LAYING ITSELF OUT 'O ATTRACT INSECTS,

eclipse of the sun, and and gloomy weather.

In No. 7 we have a branch of the common wild geranium or herb-rote t, a well-known English weed, which exhibits this peculiarity in a marked degree. Here you see three flowers awake and expanded, with their pretty purple petals (marked 
by darker lines or honey-guicles) Haunting in the sun is advertisements to the insects. The lines on the petals are not there for mere ormament : they point straight to the honey, and so save the time of the visitor, by showing him at once where he should stick his inquisitive proboscis in search of it. But No. 8 exhibits the very same branch in the evening or when clouds are obscuring the sun. Danger now looms: a shower threatens. So what does the frightened wild geranium do? Observe that the overblown flowers, the buds, and the leaves retain their positions as before : rain cannot hurt them. But the three open flowers bend their heads against the storm, instead of closing their petals : they convert themselves into an umbrella, thus temporarily

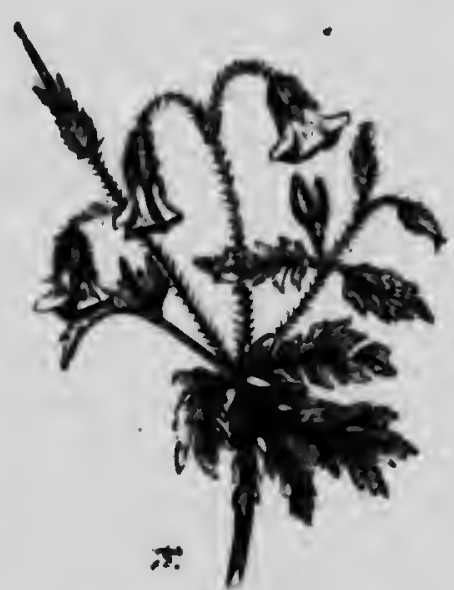

NO. 8. - WILI) geraniUm, AT NIGHT UR IN CLOUDY WEATIER, MAKING EACII FI.OWER INTO AN UMHRELI.A FOR THE PROTECTION UF THE PULLEN. imitating the tactics of the bluebells and the snowdrops. By this simple device, the honey and pollen are secured from danger. When day or sunshine returns, the geranium raises its lolling heids again, because its flowers are small and inconspicuous: they depend upon minor insect visitors-flies or the like - and cannot afford to do without the 


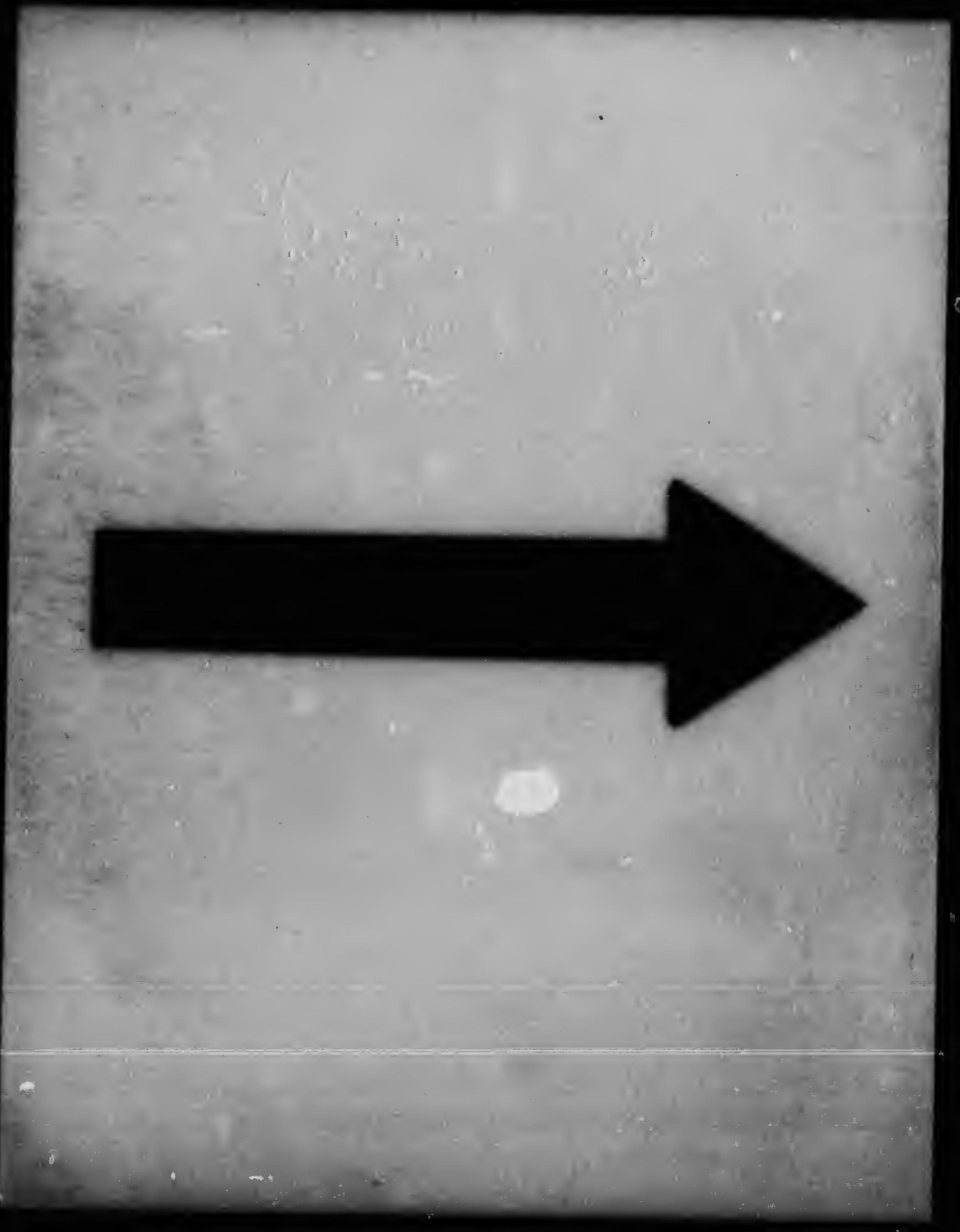


MICROCONY RESOLUTION TEST CHART

(ANSI and ISO TEST CHART No. 2)
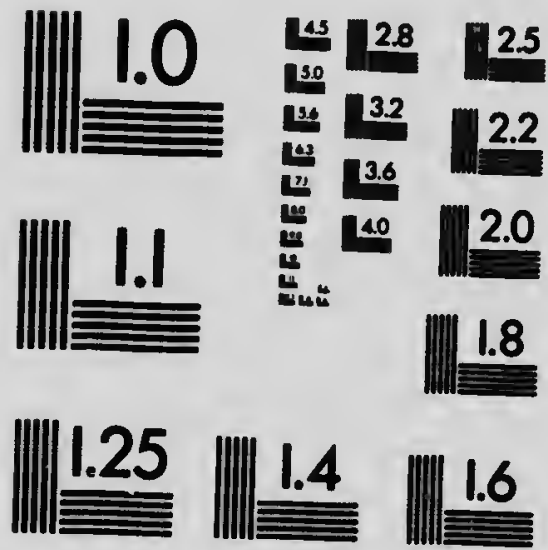

APPLIED IMAGE Inc

1653 Eost Moin Street

Rochester. New York 14609 USA

(716) 482 - 0300 - Phone

(716) $288-5989-$ Fox 
display of their purple upper-side, like the far more noticeable hyacinths and harebells.

A clifferent method of compassing the same result is seen in that queer English weed, the carline thistle. It is a very common plant on our chalk downs, and on many dry hillsides : it abounds, for

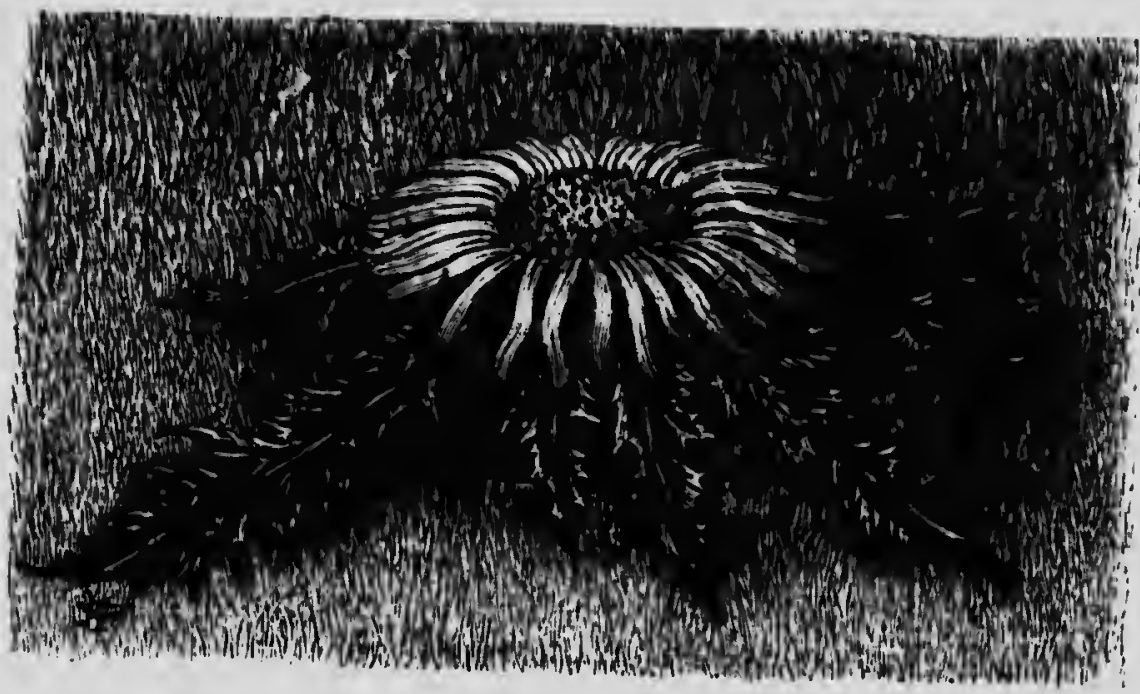

NO. 9.-CARLINE THISTIE, ITS BRACTS OPEN AND ACTING LIKF PETALS TO ALLURE INSECTS.

example, on Box Hill : and yet, if you are not a botanist, I greatly doubt whether you will ever have noticed it. For it is a curious creature which always looks dead, even when it is most alive: you can see it in No. 9 much as in real life, only you must remember that its colour is almost that of a dry dead thistle. Its leaves are cottony; its flowers 
are dingy in hue ; and its general aspect is suggestive of death, decay, and dissolution. Yet it is really very much alive: and its form is so admirably adapted to its place in nature, that I think before I describe its mode of sleeping I must first devote a few lines in passing to its other dodges for picking up an honest livelihood.

The carline grows only on dry fields, high open sheep-walks, and sandhills by the sea. All these places are, of course, much liable to be browsed over by sheep, cattle, donkeys, and other animals, not forgetting the destructive rabbit and that strangest of all grazers, the goose-a bird which puts itself into competition with the herbivorous ruminants, and crops the meadows with its bill shorter and closer than any of them with their teeth. Now, all plants which live under such conditions are obliged to adopt protective measures against animal depredators. Most of then are prickly: such are gorse, blackthorn, and the common thistles: nay, there are even certain herbs, like the pretty pink restharrow, which are unarmed when they grow in enclosed meadows, but which produce a special prickly variety when they occupy spots exposed to donkeys, rabbits, and geese, the worst and deadliest of grazing enemies. Other plants defend themselves in subtler ways, by bitter juices, or by unpleasant hairs dotted about over their surface. Yet others, like the subterranean clover, bury their ripening pods underground, so that their seeds at least may escape the keen-eyed depredators. The thistles of rich meadows have long stalks and rise a foot or 
two high: but on the fine sward of chalk downs a special species has been developed, known as the Stemless Thistle, which consists simply of a rosette of prickly leaves, in whose midst a compact head of flowers lies pressed close to the ground, and well protected by the prickly points of the leaves around it. Incleed, the whole nibbled turf of the downs consists everywhere of creeping cr low-growing plants, specially designed to flower and fruit, and so reproduce their kind, in spite of the murderous assaults of animals to which they are continually subjected.

It is in the midst of such a stunted world as this that the carline has to carve itself out a niche in nature. Its leaves, as you can see in No. 9, are pressed flat against the ground, looking almost as if they had been trodden into it-a peculiarity still more noticeable in the specialised form of plantain evolved in chalk country, on whose lawns it is a weed much hated by gardeners. These leaves are intensely prickly, with long and rigid spines protecting them at all angles from the attacks of nibblers. The whole carline plant is remarkably rigid and juiceless; in winter it looks absolutely dead, but revives again in spring as if by a miracle. In the centre of the rosette of spiny leaves a flower-head develops, looking at first sight like a single flower, but consisting really of many tubular bells, clustered together in a round group, and enclosed by an involucre or prickly basket of bracts. The inner bracts of this basket are long, slender, and raylike: in texture they are thin and shining like 
straw, while in hue they are of a pale straw colour, so that they add altogether to the dead-alive aspect of the plant. But when these shining straw-coloured bracts are spread out horizontally in the sunlight, forming a crown about the true flowers or little bells in the centre, they produce precisely the effect of petals, and serve the same purpose in attracting the notice of the fertilising insects. No. 9 shows you the aspect of the carline in these its most alluring moments, when it is laying itself out to be agreeable to visitors.

That is the attitude it always adopts in bright dry weather, when the winged guests on which it depends for fruiting are around and active. Its bracts then spread out like the rays of a star, and mimic the true ray-florets of a daisy or a chrysanthemum. But when the air becomes damp the bracts, which are highly sensitive to moisture. curl up of themselves, as you see in No. ro, and form a sort of hut or shed above the true flowers in the centre. The conical tent or pent-house thus produced makes a shelter against the impending rain, which would wash away the pollen and dissolve the honey. The illustration shows you very well the general arrangement of the plant and its parts, consisting outside of a rosette of spinous leaves, and inside of a basket or involucre to guard the flowers : this involucre itself being once more composed of two distinct parts; the outer layer of prickly and protective bracts, designed to ward off browsing enemies, and the inner layer of thin, dry bracts, with a shiny texture like that of : everlastings, 


\section{IN NATURE'S WORKSHOP}

designed in dry weather to play the part of petals, and in wet to rise up as an umbrella or rain-shelter.

The word carline is good old English for a withered old woman, a wizened witch, and it is very aptly applied to this curious and tattered grey weather-beaten species. Robert Burns applies it to

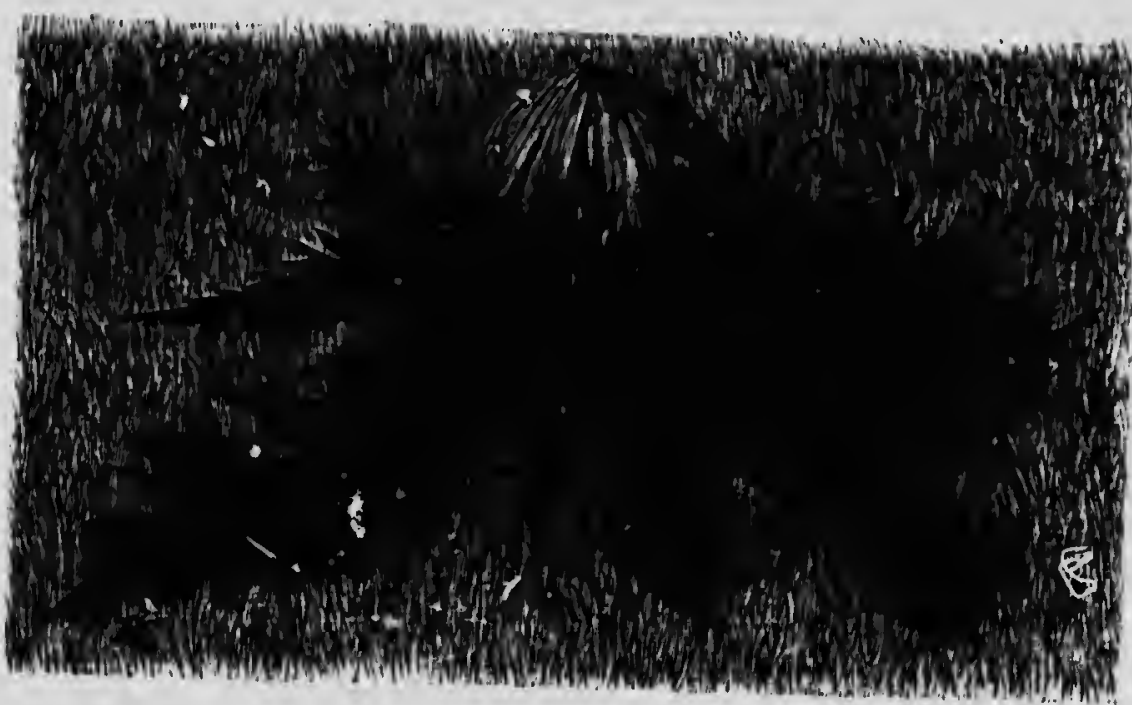

NO. IO.-CARLINE THISTLE : CLOUDY WEATHER OR NIGHT : THE BRACTS CLOSE AND FORM A PENT-HOUSE TO PROTECT THE FLOWRRS.

the hags whose orgies were interrupted by Tam o' Shanter.

Most plants and most animals sleep by night and wake by day. But there are of course a number of kinds, both in the animal and vegetable world, which find it pays them best to be nocturnal. Day is the time when most enemies are abroad : therefore, to get the better of the enemies, it may be 
well to sleep by day and turn out in the twilight. Defenceless species, no doubt, begin the game: they fly abroad in the dusk to secure safety from birds and other aggressive foes. That is the policy of the moths, the lireflies, the mosquitoes, and many other night-flying insects. Then the bats and the night-jars discover in turn that it is worth while to prowl about at night, in order to swoop down upon the insects which have thus tried to escape from the swifts, the swallows, the martins, and the flycatchers. Similarly, the smaller mammals, such as mice and shrews, go out by night in search of beetles: and the owls follow in search of mice and shrews. Thus the larger lialf of nature is by habit diurnal, while the smaller half has become nocturnal, either to escape its enemies or to capture its prey. It is like the human case of guns and armour : we make armour-plated ironclads so thick that no gun can pierce them; then we inveni new guns which can pierce even the impenetrable armour. Nature is one vast game of check and counter-check: it consists of devices intended to outwit other devices, and themselves outwitted in turn by devices still more stringent or more marvellously cunning.

Now plants too have followed the general fashion of producing nocturnal types, wherever the circumstances rendered it desirable for them to do so. The night-flying moths are in many cases honeyeaters, therefore they may be utilised as carriers of pollen by any enterprising plant that chooses to lay itself out for securing its services. Here are so many Pickford's vans, as it were, going begging : 
the plant that chooses to flower at night and close by day will be able to get its fertilisation done cheap, with greater certainty than if it had to compete with the ruck that opens every inorning. So a great many flowers have taken the hint and laid themselves out for this twilight blossoming. I will give you one simple example first, and then pass on to more complex cases.

Everybody knows the common English red campion-the day lychnis, or Robin Hood as it is often called in the country. It is a pretty pink flower, scentless and somewhat weedy, and it grows abundantly in hedgerows all over England. It is pink, because it is principally fertilised by dayflying butterflies, which love bright colour : it needs no perfume, because its brilliant hue is sufficient advertisement for all practical purposes. But it has a very near relation, almost exactly like it save in two respects : and this relation is the white evening lychnis or night-flowering campion. It differs from the red campion, first in colour, and second in being delicately and pervasively scented. Why? Because it opens its blossoms about five or six in the evening, in order to catch the night-flying moths. These moths are chiefly attracted by white flowers, which show up best in the grey dusk of evening: and they are also guided very largely by scent, so that blossoms which lay themselves out for the patronage of moths are almost always heavily perfumed.

A few more examples will show you some other peculiarities of this group of night-blooming moth- 
alluring blossoms. Everybody now knows the socalled "tobacco-plant" or Nicotiana affinis, so greatly cultivated of late in gardens. This beautiful and graceful flower closes during the day, but opens at nightfall, when its pure white blossoms become strongly scented. If you are at all in the habit of noticing flowers, too, you must have observed that the "tobacco - plant" is almost selfluminous in the dusk: it glows with a strange phosphorescent light, as if illuminated from within. This is the case with many nocturnal flowers, and I suspect (though I do not know) that the property is connected with their insect-eating habits, about

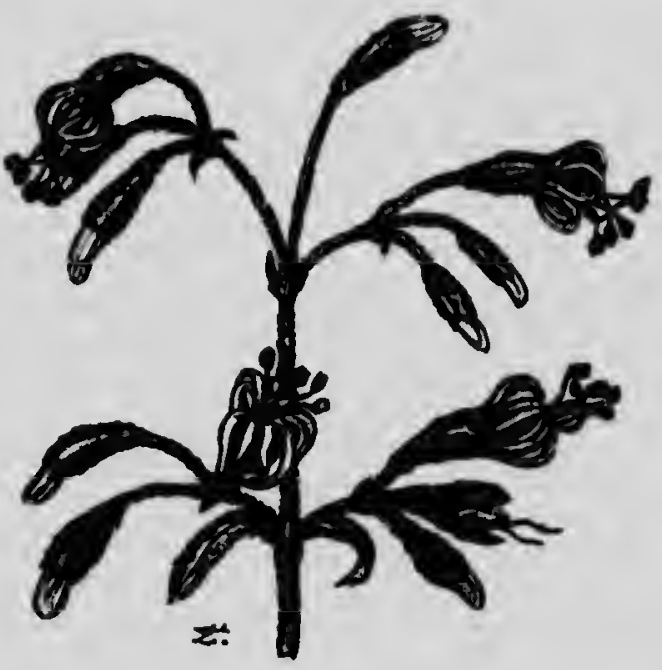

NO. 11.-CATChFL, A NOCTURNAL. PLANT, SLEEPING BY DAY, WHEN ITS MOTHS ARE ABSENT.

which more by-and-by. Again, you may note that there are a large number of similar night-flowering plants, all of them moth-fertilised, such as gardenia, white jasmine, tuberose, stephanotis, night-flowering cereus, and so forth. All of these are pure white, and all of them are heavily scented with very similar perfumes. Moreover (and this is a curious 
coincidence), none of them have any streaks, spots, or lines on their petals. The reitson is simple. Such streaks or lines are always honey-guides, to lead the insects straight to the nectary. Day insects see such lines and are greatly influenced by them : but at night they would be useless, so their

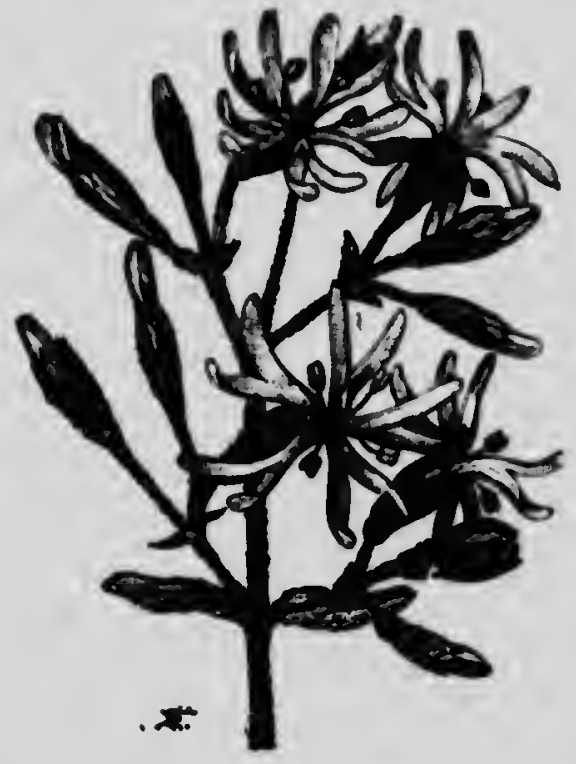

NO. 12. - CATCHFLY, ORENING ITS WHITE PETALS AT NIGHT, WHEN ITS MOTHS ARE FLYING. place is taken by scent and by deep tubes, which make a dark spot near the centre of the blossom. What night flowers need most is a bright white surface which will reflect all the small light they can get : and this I suspect they sometimes supplement by a faint phosphorescence.

The Nottingham Catchfly, which you see asleep by day in No. II, is a highly developed example of these nocturnal

flowers. During the daytime it cover ; its blossoms by bending its petals inward, so as to preserve its honey from casual diurnal visitors, and keep it till night for the regular customers. At evening it opens them again, as you see in No. 12, displaying its brilliant white inner surface, which is dazzling 


\section{Plants that go to Sikel}

in its purity. But why, you may ask, does it not avail itsel? of the day insects as well? Because they are "ot the ones specially fitted to do its worit: th. is heads are not of the right shape : the Nottinglam Catchfly has laid itself out for special moths, and has so formed its hlossoms that those moths can fertilise it most easily and most economically. It is a good example of a highly developed type, specially fitted for a particular visitor.

The name of Catchfly, again, it owes to an odd peculiarity which it shares with many other nocturnal flowers. The top of the sten at the flowering period is covered with sticky hairs, which have glands at their iips: and these glands exude a peculiar viscid liquid. Small flies light on the stem, and are caught by the sort of bird-lime thus prepared for them ; the plant then digests them and sucks their juices. I do not know whether my next guess is correct or not-I am not chemist enough myself to verify it : but I am inclined to conjecture that the plant uses up the phosphates in the bodies of the insects in order to produce the peculiar luminous appearance of the petals in the twilight. 1 leave this hint for those of my readers whose chenrical skill may be greater than mine is. 


\section{IV}

\section{MASQUERADES AND DISGUISES}

T $\mathbf{N}$ a previous chapter of this book, I introduced my readers to certain bold and deceptive insects - the "bounders" of their racewhich pretend to powers they do not possess, and endeavour by sheer bluff to frighten away intruders on their domestic privacy. In the present chapter, I am going to touch on sundry other wily animals which, either in order to escape the notice of their foes or to creep in silence upon their unwary prey, imitate more or less closely other objects in their surroundings -in simpler words, walk about in masquerade. This chapter is thus to be devoted to the subject of disguises. I propose, as it were, to go behind the scenes, and show you the make-up of the principal characters in nature's melodrama of "Strictly Incognito."

An ounce of example is worth a ton of description: so I will begin with a simple illustrative case among the class of fishes. My illustration No. I shows a "person of the drama" without his make-up : it represents that familiar little beastie, the common sea-horse, or hippocampus. In his dried condition, this quaint 


\section{Masquerades and Discuises}

small Mediterranean fish is a well-known denizen of every child's domestic museum. Visitors to Venice have picked up sea-horses in abundance on the sandy ridge of the Lido-that long bank of shingle which divides the lagoons from the open Adriatic, a spot which I have already mentioned in my writings as a favourite haunt of my own, and also of my good old friend the sacred scarab or ball-rolling beetle. In most marine aquariums, too, the sea-horse is a much-appreciated popular performer : a group of them in the Brighton Aquarium (which, though you may

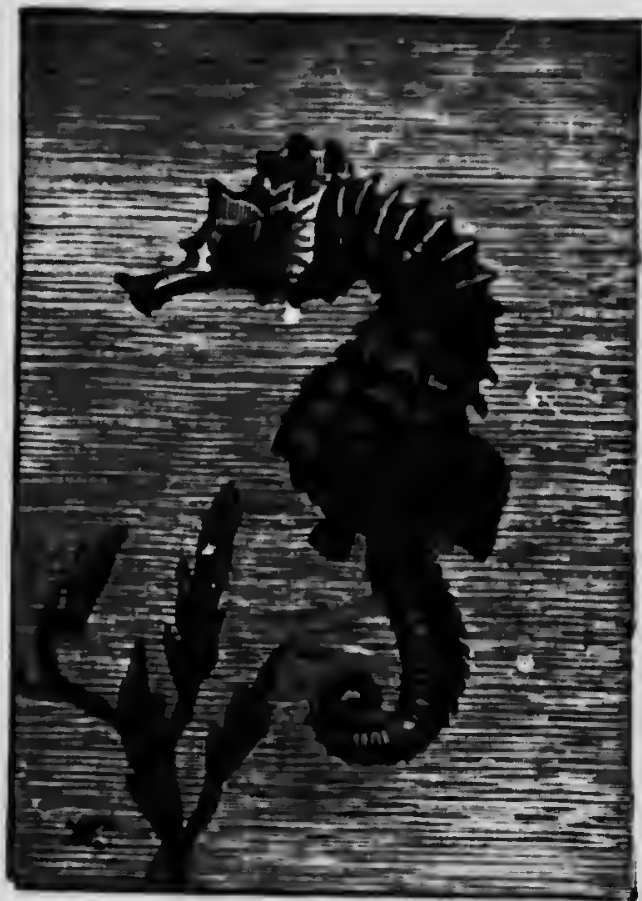

NO. 1. - THE SEA-HORSE, UNDISGUISED, SEDATEI.Y SWIMMING.

not know it, contains tanks with fish in them always receives an early call from me whenever I happen to be anywhere in their neighbourhood. By these means it comes about that even those who do not go down to the sea in ships have 
become fairly familiar with the appearance of the sea-horse and with his mode of life, which he pursues unaltered-being indeed a sluggish

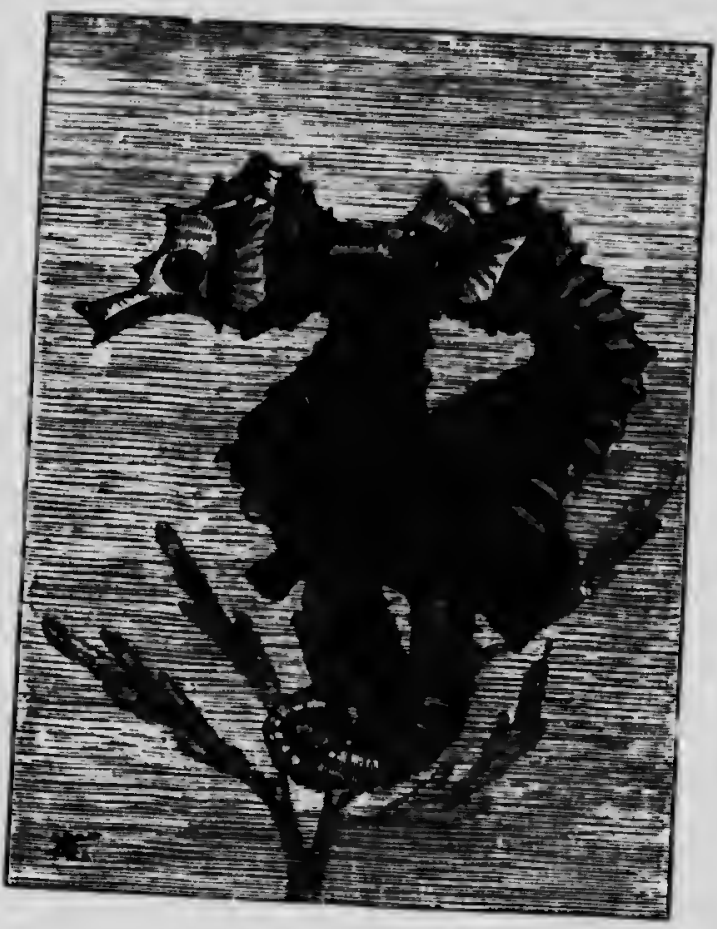

NO. 2. -A PAIR OF SEA.HORSES, MOORED TO A FuCUs. and phlegmatic brute - in a shallow basin as in the open Mediterranean. In general shape, as you see, the hippocampus bears a striking resemblance to the knight in a set of chessmen. But instead of a round stand, he has a prehensile tail like a monkey's, by means of which he can securely moor himself to pieces of seaweed or other small objects. This is his usual attitude when not swimming. No. 2 shows a couple of hippocampi so curled together in friendly cumpanionship on a spray of some fucus. One may often observe a dozen or so of them thus intertwined by their tails in an inextricable knot -inextricable, that is to say, till you notice one 
of them display a nascent desire in his small mind to untie himself. Then you begin to perceive a sinuous wriggling movement in the coils of his tail, which communicates itself by degrees to his slimy comrades. For about a minute the would-be rover is engaged in disentangling his own nether part from the nether parts of his companions; at last, with a triumphant gliding motion, he sets himself free, and begins to swim, half upright, as you see in No. I, with a sedate and churchwardenly motion, through the water about him. His fins, it is true, vibrate with extraordinary rapidity, like a waving ribbon; in spite of which he moves almost imperceptibly forward, and never goes more than a foot or two at a time in any direction. Though armed with a rather knobby and prickly coat, the sea-horse is exposed by the mere slowness of his gait to the attacks of more active and energetic enemies.

Our European sea-horse, as you can see in these illustrations, makes no pretence at concealment: he moves about undisguised, like an honest gentleman, and can be readily recognised whereever you meet him. But there is an Australian relative of his, the leaf-like sea-horse (known to men of science as Phyllopteryx), which is much softer and more palatable in the body, and therefore stands in greater need of protection from predatory fishes. This curious ragged creature, shown in No. 3, has its tail and fins provided with irregular long waving appendages, exactly resembling in form and colour the seaweed in 
which it lurks. In the drawing, to be sure, Mr. Enock has represented the fish rather isolated, so as to let you clearly distinguish it from the neighbouring weeds; but you can easily understand that in nature, when it is lying hid in a knotted mass of such seaweed among the overgrown rocks at the bottom, it must be very

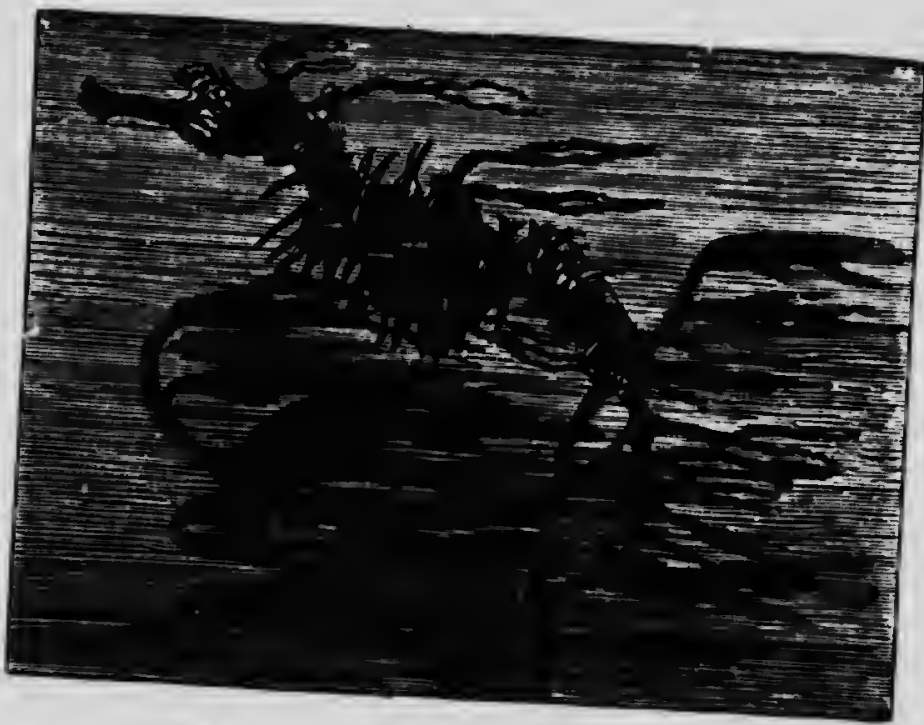

NO. 3.-AUSTRAlian SEA-HORSE, DISGUISED AS SEAWEED.

difficult for even the sharpest-eyed enemy to pick it out from the fronds it so closely resembles. The tint, in particular, is absolutely identical.

How does this quaint resemblance come about? Probably in this manner. All the sea-horses of this kind which could be discovered by enemies for many ages have been assiduously eaten. If 


\section{Masquerades AND Disguises}

every one of them had been eaten, however, the species would now be extinct : and this is really what has happened over and over again to many species in the sea, as it has happened on land in our own time to the American bison, the great auk, the inoa of New Zealand, and several other creatures. But if any sea-horse of this more threatened class happened to resemble the seaweed in which it lived, either in form or in colour, or in both, rather more than the rest of its kind, it would stand on the whole a somewhat better chance of not getting eaten, and would on the average leave more offspring than its less protected fellows. Thus, from generation to generation, as enemies poked their noses into the tangled weed in search of food, the tendency would be for the more seaweed-like to escape and mate, while the less seaweed-like were detected and eaten. This is what we call "natural selection," or "survival of the fittest." The result would be that the protected, mating always with the protected produced young like themselves, and that out of their offspring the ones least like seaweed would still oftenest get devoured, while those most like seaweed still escaped.

The leaf-like sea-horse is a simple case of what is now known as protective resemblance. A very similar instance is that of the so-called skeleton shrimp, which also moors itself to bits of seaweed, and looks just like the plant it clings to. But the same sort of thing occurs on a large scale among the entire group of animals inhabiting what is 
called the Sargasso Sea. This sea is a belt of the Atlantic near the Azores, where great masses of a particular tropical seaweed, known as sargassoweed, mat together so as to form perfect floating meadows, and oiten even impede the navigation of vessels. The weed is pale yellow in hue, and is inhabited by vast numbers of small marine animals -crabs, prawns, and the like-all of which are protectively coloured exactly like the weed on which they live. I have often had

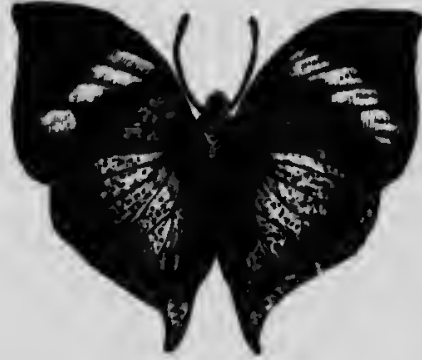

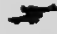

NO. 4.-KALLIMA BUTTEK. FLY, DISPLAYING ITSELF WHILE FLYING.

crabs and fish which inhabit general. My specialised next example will be of a more of a species No. 4 represents a butterfly and known as a Kallima. That is how it while it flies about coquetting in the open sunshine, displaying its brilliant hues, and seeking to attract the attention of its observant mate. Under such circumstances, it is a beautiful creature : its wings are dark brown at the tip, and crossed by 


\section{Masquerades AND Disguises}

a bright yellow band; the under wing being blue, with shot hues running through it. A very gallant gentleman indeed the male Kallima appears when thus flaunting his beauty in the tropical sun before the eyes of the ladies of his species.

But let some enemy threaten, some bird pounce down upon him, and the Kallima butterfly has an easy refuge. He need but settle down quietly on a neighbouring bough, and hi, presto! all at once he seems to have put on the cap of invisihility. If you are chasing one of these butterflies, and he alights on a tree, you imagineatfirst that he has disappeared entirely. And so he has, though only from

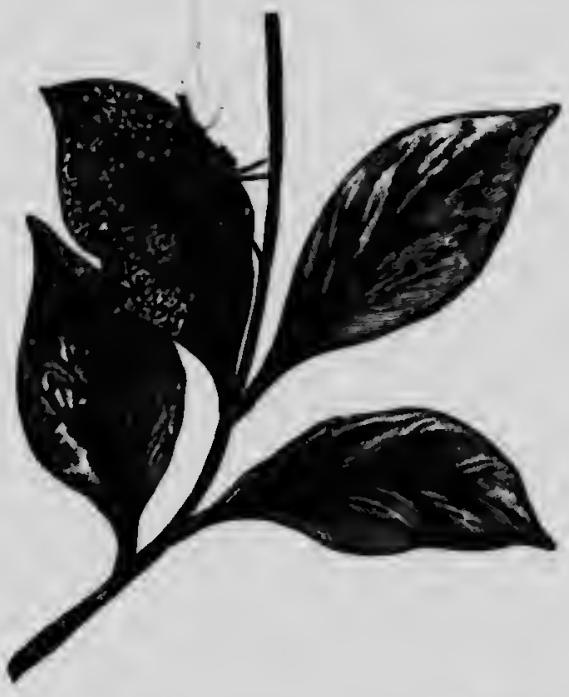

NO. 5. -THE SAME KALI.IMA, SETTI.ED ON A TREE : PUZZI.E, TO FIND THE BUTTERFIY. your vision. At rest, he is indiscoverable. No. 5, if you look close, contains the explanation of this "mysterious disappearance of a gentleman." But you must look close if you want to find him out in his excellent disguise. The branch, you see, has four leaves on it: well, the uppermost left-hand leaf is our vanishing butterfly. The under-sides of

$$
\begin{gathered}
\text { rLIE PROPERT: OF } \\
\text { IC A RBOSRO } \\
\text { FUBLIC LIBRARY. }
\end{gathered}
$$


his wings are coloured and lined so as exactly to imitate the leaves of his favourite bush, on which he usually settles. Mid-rib and veins are all carefully imitated: while the actual body and legs of the insect become quite unobtrusive. Indeed, in real life, the imitation is even more perfect, owing to the addition of colour, than it seems in the sketch, for here you have $\mathrm{Mr}$. Enock's sharp eyes-and I know none sharper - to pick out the creature for you, apart from all the leaves on the tree it inhabits; whereas, in nature, you would have to hunt it up for yourselves among a whole bushful of foliage, all exactly like it.

Residents in London can easily try for themselves this interesting game of hide-and-seek with a vanishing butterfly: for in the vestibule of the Natural History Museum at South Kensington there is a case of animals intended to illustrate protective resemblances; and conspicuous in the case is a large group of these very butterflies, some of them almost impossible to detect among the leaves around them. It is noticeable, too, that similar types of double colouring - for display and for protectionare common in nature. The upper-side of the winge is visible only when they are unfolded, and the insect is consciously showing off his charms in the sunshine to his mates : he then desires to look as handsome, as well-dressed, and as conspicuous as possible. But the under-side is shown when he rests with folded wings on a twig; and his obvious cue is then to escape observation. In the one case, 


\section{Masquerades and Disguises}

he is the gallant at large; in the other case, the fugitive in hiding.

Similar instances of protective resemblance, produced no doubt by natural selection, are now well known in many different classes of animals. The most familiar are the leaf-insects of Ceylon and Java - wonderful green creatures with ribs and veins like those of leaves, so deceptively arranged that, as Mr. Alfred Russel Wallace says, "not one person in ten can see them when resting on the food-plant close beneath their eyes." Others of the class imitate bits of stick, with little knots and branches, so that one can only recognise them as alive when one touches them. A stick-insect brought to Mr. Wallace in Borneo so exactly mimicked a piece of stick, covered with green mosses and liverworts, that it fairly took in even that lynxeyed naturalist. That these protective devices do really benefit the animals which exhibit them there can be no doubt at all : for Mr. Belt saw a locust in Nicaragua got up as a leaf, and absolutely overrun by foraging ants, hungry carnivores which devour every insect they come across like a ravening army: yet they never even discovered that the apparent leaf they were walking over was itself a store of good ant-meat. The locust, on the other hand, fully recognised the nature of his immunity from attack, and understood that if he moved a single limb he would betray himself : for he allowed Mr. Belt to pick him up in his hand, examine him closely, and replace him among the ants, without making an effort to escape or a movement to reveal 
his true nature. This trick of "shamming dead," as it is called, is common among beetles and many other insects.

In most of the cases known to us, such imitations are due to the need for protection alone. Sometimes, however, the tables are turned: animals which prey upon others deceive their prey by posing as something quite harmless and even attractive. Thus the lizards of the desert are usually sand-coloured, so that they may creep up unobserved upon the insects they devour; while in the Arctic snows, all the beasts and birds alike are snow-white, because there a black or red animal would be seen and avoided at once by all its possible victims. One of the strangest instances I know of imitation in a hunting creature occurs in Java. There is a type of creature allied to the grasshoppers and known as the Mantis, many species of which in various countries are specialised into leaf-insects : they are voracious creatures, with lo.1g arm-like fore-limbs, which lie in wait for and devour many smaller insects. One such Mantis in Java is coloured pink, and resembles when at rest a pink orchid. The butterflies on which it feeds mistake it for a flower, alight on what seem its petals in search of honey, and are instantly seized by the ruthless hand-like claws and devoured without mercy. As Mr. Wallace pithily puts the case, "It is a living trap, and forms its own bait."

Examples like this lead one on to the still more remarkable group of facts known as mimicry. It might almost be called impersonation. A certain 


\section{Masquerades and Disguises}

number of animals belonging to the most different families have the odd peculiarity of resembling, or as it is often called "mimicking," sundry other animals to which they are not really in the least degree related. As before, I will begin with a single good typical example of such mimicry, and when we have thoroughly comprehended its nature and meaning, will pass on to the principles which govern the practice in

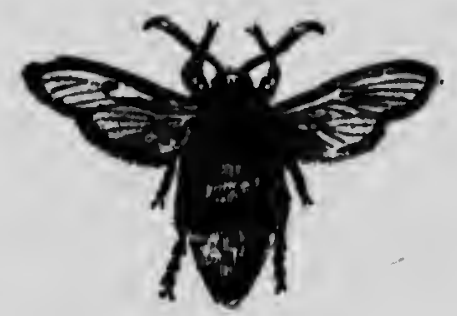
all similar cases.

No. 6 shows us, below, a specimen of the common English hornet. Now, everyhody knows that the hornet is a large red and brown and yellow wasp, very active and irritable, with a nasty, aggressive temper, and an unpleasant way of stinging on the slightest

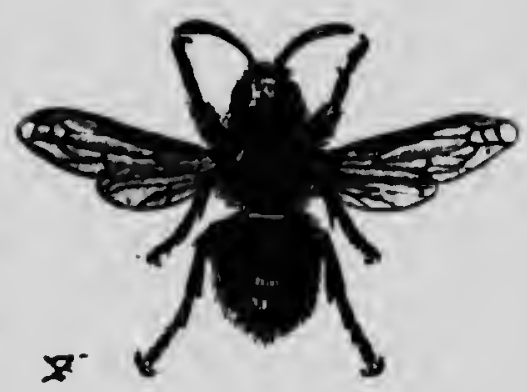

NO. 6--LOWER FIGURE, THE COM. MON HORNET : UPIER FIGURE, THE MOTH WHICH PERSONATES IT. provocation, or none at all for that matter. Furthermore, everybody who has once been stung by a hornet-as I have been not infrequently in the cause of science-is keenly aware that a hornet's sting bears to an ordinary wasp's the same relation as scourging with scorpions bears to scourging with 
rods. On this account, hornets are generally let severely alone by birds and other insect-eating creatures. It must clearly be an advantage to the wasps and hornets that they possess a sting : and its chief point is just that-it protects them from attack by possible enemies.

Again, almost all specially-protected creatures, as I mentioned once before in the case of the nasty. tasted and inedible caterpillars, are very brilliantly and conspicuously coloured. The contrasted bands of black and yellow in the common wasp, which render him so easily recognisable at sight, are a familiar instance. Such vivid bands or bright tints have been well described by Mr. Alfred Russel Wallace as "warning colours." The moment we see a bright black-and-yellow-belted insect alight with a buzz on the fruit at dessert, we say at once to the little ones, "There's a wasp! Don't touch him!" This almost instinctive fear which the mere sight of the venomous insect inspires in onlookers is all to the good for him : it serves his end by preventing us from handling or crushing him. Still more do the lower animals give such insects a wide berth: a very young and inexperienced puppy, it is true, will sometimes make an imprudent snap at a passing wasp; but the piteous way he licks his tongue afterwards, and the dejected attitudes by means of which he tells us that he is very sorry for himself, show before long that the wasp, though vanquished, has left his mark behind him. That puppy, you may be sure, will never try to snap at another bright yellow-banded insect as 
long as he lives: when one huzzes about him, he will put his tail between his legs like a wise dog, and retire incontinently into safer quarters.

It is now well known that whenever we find animals belonging to usually sober families, but tricked out in gaudy red or orange or yellow, they are almost invariably 1..otected in one way or another-are either venomous, or stinging, or nasty to the taste, or else possess, like the striking blackand-white-banded skunk, the power of ejecting an offensive and irritating odour. A famous instance of this conjunction of inedibility and brilliancy is "Belt's frog." In Nicaragua, that close observer, Mr. Belt, found a small kind of frog, gorgeously arrayed in crimson and blue, and swelling about like King Solomon in all his glory. Frogs of this dazzling sort were extremely abundant in Nicaraguan woods, and never made the slightest attempt at concealment. Now, it is the common habit of land frogs, all the world over, to be protectively coloured with brown or green, according as they haunt most the ground or the foliage of trees. The common little tree-frogs so abundant in most warm climates, for example-every visitor to the Riviera must know them well-are either a brilliant grass-green, to imitate the foliage to whose under-side they cling by their sucker-padded feet, or else are mottled with grey and white and brown, to mimic bark, dead leaves, and lichen-covered branches. So Mr. Belt felt convinced that his Nicaraguan frog, which behaved so differently from the rest of its kind-which was so brilliantly 
dressed and never tried to hide itself-must be venomous or inedible. He tried the question by giving a few frogs to his fowls and ducks: the wary birds looked at them suspiciously, put their heads on o:je side, and refused to tuuch them. At last, by throwing a single frog down unobtrusively among pieces of meat for which the ducks were scrambling, he managed to induce a young and inexperienced duck to pick up the creature. "Instead of swallowing it, however, the duck instantly threw it out of its mouth, and went about jerking its liead as if trying to get rid of some unpleasant taste." I have myself experimented in the same way on some brilliantly-coloured slugs, which cover rocks in the open, and can and my personal testimony to that of Mr. Belt's witness, the incautious duckling.

But I am wandering from the question. Let us return to our pictures. The upper insect in No. 6 represents, not a hornet or relative of the hornets, but a moth, deceptively coloured so as to mimic and suggest the horne. kind. Bees and wasps, being species that enjoy immunity from attack, are naturally very much imitated by other insects. The whole family to which this imitation hornet belongs, indeed-that of the clear-wing mothsseems to have laid itself out on purpose to personate the wasps and bumble-bees, for almost every species is an imitator of some particular species of stinging insect. Of course the moths are themselves quite harmless soft things : but they look like wasps or horrets, and that is enough to protect 


\section{Masquerades aNi) Disguises}

them. They produce their effect in a very odd manner. Most moths, as we know, have feathery wings, covered with a fine powder of dust-like scales; but the clear-wings have got rid of the scales, so as to resemble wasps and bees with their membranous wings; and it is this peculiarity in their structure which gives the common English name to the family. Not only, however, are the wings transparent, but the bodies also are shaped much like those of wasps and hornets, and are conspicuously banded with red and yellow. The antenna, too, are made as wasp-like as possible. The clear-wings fly about rapidly in the open sunshine, and their flight resembles that of wasps and bumble-bees, according to the model selected for imitation by each species. Indeed, the resemblance is much greater in real life than in Mr. Enock's sketch, because the colour is so deceptively similar. No ordinary person who saw a hornet clear-wing would dare to put his hand upo:s it, even if told it was harmless: naturalists themse!res look twice before they venture incautiously to linger a doubtful specimen.

The hornet clear-wing is a great frequenter of poplar trees, in the wood of which the larva burrows; and in No. 7, Mr. Enock has shown us the same two insects again, at rest on the bark of a branch of this favourite food-tree. As before, the hornet is still below, and the moth above; but in this instance, even without the aid of colour, the deceptive resemblance becomes still more conspicuous. If, while the moth is thus sitting in the sunshine on 
a trunk of poplar, you try to touch its body, it will perform one of those curious "terrifying" evolutions which I have already described in so many insects. It will curve its back, and dig once or

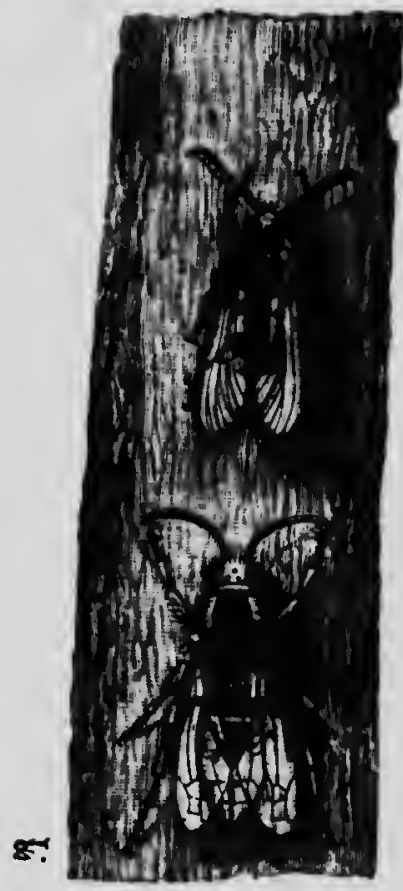

NO. 7. - HORNET AND HORNET CLEAR-WING MOTH ON A BRANCH TOGETHER.

bumble-bee and are parasitic on the grubs of the thusble-bee and wasp : and the female Volucella is thus enabled to enter the nests of bumble-bees, and lay her eggs among those of the real owners, whose larve the fly larvie will finally devour. It is true that 


\section{Masquerades and Disguises}

doubts have lately been cast upon this fact, because the Hy which imitates the bee has been seen to enter the nests of wasps : but I do not attach much importance to this objection, which needs even now to be more widely demonstrated. At any rate, these facts remain, that various kinds of Volucella mimic various kinds of bumble-bee, and that the young of one devour the young of the other. For my part, I say confidently, a clear case of loitering under disguise, with intent to commit a burglary.

The case of the bumblebee and the Volucella fly is an excellent example also of the extent to which alone mimicry is possible. I said above that anisals of quite different families mimicked one another: and you can see for yourselves here just how far the imitation goes,
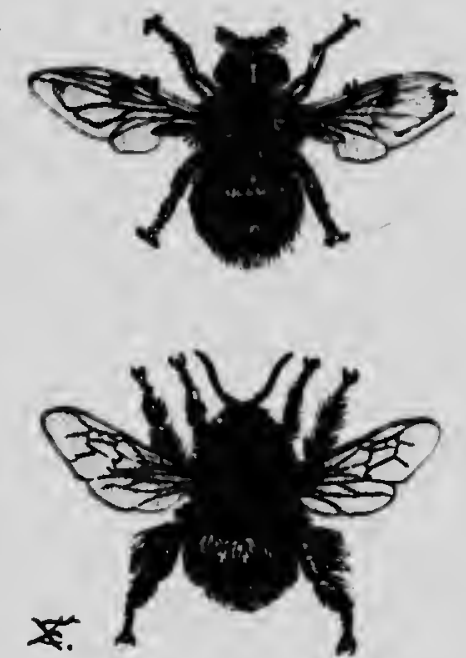

NO. 8. - LOWER FIGURE, BUMBLE - BEE : UPPER FIGURE, FLY WHICH IMITATES IT. and where it fails. For the bees have two pairs of wings each, folded one slightly under the other; but the whole group of flies has practically only one pair, the second or hinder pair having dwindled away to a couple of slender little "poisers," or "balancers," which you can see sticking out from the side of the upper figure in No. 8 . Now, 


\section{IN NATURE'S WORKSHOP}

the fly couldn't easily re-develop these stunted and almost abortive wings to the primitive size, as one sees them in the bumble-bee; so what did it do? Made the one pair of front wings look like two pair, by means of a notch half-way

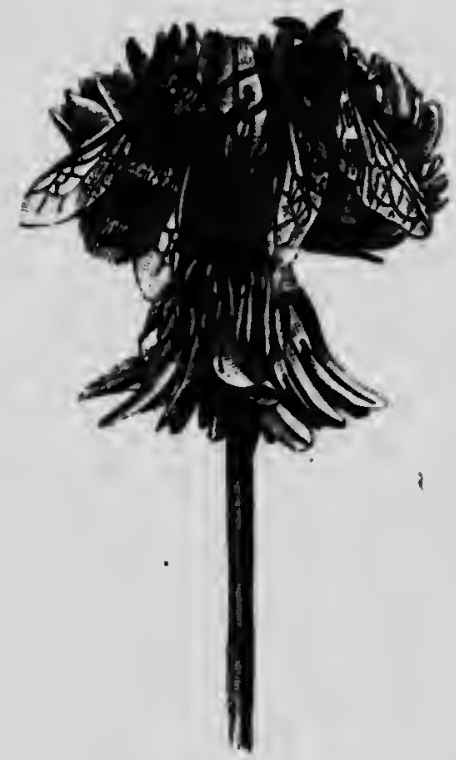

NO. 9. -THE REAL BEE AND THE FALSE ONE, ON A HEAD OF DUTCH CLOVER : WHICH IS WHICH? down the side, as you may see by comparing the two figures. 'Tis ever thus. The disguise is always external only; it affects nothing but outer appearances, leaving internal organs and u.s serlying structure of the beast unaltered. So, when a savage dresses up in the skin of a wild animal, in order to approach others of the same kind without being noticed, his disguise is external only: peel off the skin, and in essentials, beneath, he is human. It is the same with mimicry. Visible parts undergo modification: invisible parts are never altered. A legend of the stage tells us of a thoroughly conscientious actor who blacked himself all over to play Othello; nature is content with blacking the face and hands like the ordinary unconscientious player.

In No. 9 you see the same two insects, the bumble-bee and the Volucella fly, feeding side by 


\section{Masquerades and Disguises}

side on a head of Dutch clover. (You remember its trick of tucking away the fertilised blossoms.) Both are sucking honey; and it takes a keen eye to distinguish them. But lest family quarrels arise over the question, I will say that the bee is to the left, the fly to the right. These are only a few stray examples out of the numerous insects which imitate bees, wasps, and other stinging species. Often enough, indeed, I have seen ladies scream at the approach of a perfectly harmless fly, because he came to them in wasp's clothing. The drone-flies, which imitate bees, do it so well that even spiders are taken in, and treat them with caution as if they had stings.

Mimicry is not wholly confined to the smaller animals. It occurs, though sparingly, higher up in the scale of being. There are several venomous snakes, for example, in tropical America, conspicuously arrayed in alternate bands of red and black, or red, black, and yellow, which are clearly warning colours. They mean, in effect, "Let me alone, or I sting you." Now, i, the same region, three genera of unarmed and harmless snakes mimic and personate the various species of venomous banded snakes, so that it is often impossible to distinguish one from the other except by kilıng them. Naturally, snake-eating birds and mammals follow in such cases the familiar principle of the British jury, and "give them the benefit of the doubt." A few defenceless birds likewise imitate pugnacious and powerful ones, and so secure immunity from the attacks of enemies. 
How did these mimicking species arise? It was that wonderful student of animal life, Mr. H. W. Bates-the Naturalist on the Amazons-who first solved this knotty problem.

He showed that, if a helpless or palatable species of butterfly (to take a particular concrete example) happened even remotely to resemble an uneatable one, it would derive some slight advantage from the resemblance, because birds and other enemies would often be uncertain, and therefore afraid to attack it. As the birds or other enemies grew sharper, by dint of practice, the edible individuals which happened to be least like the nasty species would get detected and eaten; but those whicis happened to be most like it would be spared, and would breed together, thus handing on their peculiarities to their offspring. Among their descendants, again, those which most resembled the protected kind would escape, while those which least resembled it would be spotted and devoured. In this way the imitation would at last become almost perfect, at least as far as externals were concerned, until the enemies were no longer able to distinguish the mimic from the original. Many cases thus present, in Mr. Bates's own words, "a palpably intentional likeness that is quite staggering." Since Mr. Bates wrote his famous paper on the subject endless new instances have been accumulated, and we now know of hundreds of mimicking species, both among insects and other animals, the whole world over.

Mr. Alfred Russel Wallace, who has also paid

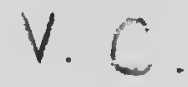




\section{Masquerades and Disguises}

great attention to this subject, has further pointed out that true cases of mimicry can be said to occur only where five distinct conditions are all fulfilled. To begin with, the imitator and the original protected species must live in the same district; for, if not, the enemies would not know and avoid the protected species : how, therefore, could they mistake the masquerader for it? Again, the imitators are known to be always more defenceless than the creature they imitate: harmless themselves, they pretend to belong to a dangerous or inedible kind. There is some sense in an antelope dressing up as a tiger, but none at all in a tiger dressing up as a hyena. Once more, the imitating species is always less numerous in individuals than the kind it personates: only rather common and well-known venomous types are ever mimickedtypes that everybody knows and avoids-and the mimickers must be relatively uncommon, or else their enemies will soon discover the fraud. It is also noticeable that the mimics always iiffer conspicuously from their own allies: they have to dress the part, a part for which nature did not originally fit them. Finally, the imitation never goes one mite beyond the merest externals : it is not a real analogy, but a disguise and a fancy dress-a superficial outer seeming.

Actual mimicry of another species, such as we see in these special cases, is the furthest pitch of which protective resemblance is ever capable. Between that and the mere general resemblance of Arctic foxes, Arctic hares, Arctic ptarmigan, Arctic 
willow-grouse, and so forth, to the snows in whose midst they live, we get every possible variety of gradation. The general principle involved appears to be this. Where the surroundings are very uniform, as among the ice and snow of the Polar regions, the protected animals are all uniformly coloured - in this case with snow-white fur or feathers. Where the prevalent hue changes, as in sub-Arctic lands, the animals may change too, being brown or grey or russet in sumner, and white in winter. Where the ordinary tint is slightly varied, as in the desert, the animals tend to be sand-coloured or speckled. The same rule holds good of the sea sands. Excellent examples of this stage are to be seen in the soles and other flat fish, which imitate on their exposed or upper side the colour of the bottom on which they habitually lie. Everybody who has watched the behaviour of soles in an aquarium must have observed not only that they are hard to distinguish, when at rest, from the sand on which they repose, but also that, in order to increase the resemblance and conceal from foes the outline of their shape, they have a canny way of flipping a little loose sand with a wave of their fins over the edge of the body every time they settle down again after a short swim. Soles frequent sand, and are therefore of a brownish sandy tone of hue ; dabs or flounders, which lurk in mud, are more uniformly mud-coloured; plaice, which affect pebbly banks, have a variegated pattern, interspersed with red spots, to imitate coloured pebbles; and turbot, 


\section{Masquerades and Disguises}

which belong to somewhat greyer tracts, are vaguely grey and spotty, with raised knobs scattered over the surface to make them look like the rough ground about them. All, however, are white on the under side; because, when they swim, the white makes it more difficult for an enemy below them to recognise them against the general shimmering glare on the surface of the water, as you look up at it from the bottom. Every swimmer must have noticed as he dives how dazzling white this surface seems when observed from below.

In woods, forests, tangled brake, jungle, copses, hedgerows, thickets, and so forth, the surroundings are much more varied, and the protective resemblances therefore become somewhat more complex. A simple case of this more special kind is that of the great cats, whose colours differ exactly in accordance with their lairs. The lion, a desert beast, is simply sand-coloured; the tiger, a jungle beast, frequenting tracts overgrown with bamboos and other big yellow reed-like grasses, has up-anddown stripes, which render him difficult to perceive as he creeps upon his prey among the up-anddown lights and shadows of the pale straw-coloured dead grasses in his favourite ravines; while the tree-cats, such as jaguars, ocelots, and so forth, are spotted or dappled, because the spots make them more difficult to recognise among the round lights and shadows in their native forests. Spotted deer and antelopes also belong to forest regions; while almost all of those with vertical stripes are constant frequenters of deep grasslands. 


\section{IN NATURE'S WORKSHOP}

Smaller creatures go yet a step further: they imitate not merely the general effect, but particular objects in their surroundings, such as leaves, sticks, bits of moss, and lichens. Certain greyish moths, for example, pretend to be bird-droppings; while

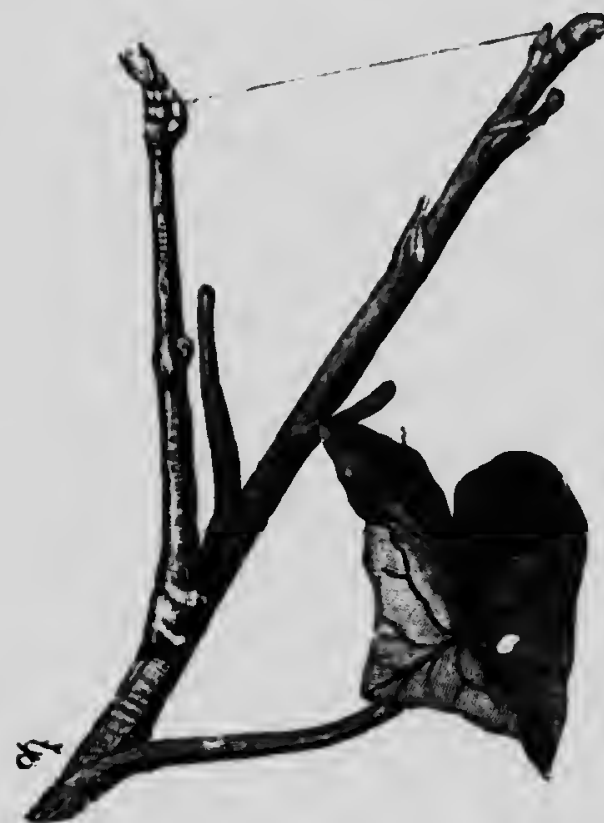

NO. IO. - CATERPILI.AR OF THE SWALLOW-TAIL MOTH, PRETEND. ING TO BE A TWIG OF IVY. many spiders fold themselves up in the angle between a leaf and the stem, and masquerade as buds, on the hunt for insects. A group of plant-bugs cover themselves al! over with thin threads of white wax, which they secrete themselves; and they are then mistaken for fragments of wool, rubbed off and left behind on the bark of the tree by some passing animal. Caterpillars and grubs are particularly given to this class of deception : and, considering low ruthlessly they are persecuted by birds, the sternest moralist can hardly blame them. No. Io represents one such typical pecimen: the ingenious larva of the swallow-tail moth, pretending for all he is worth that he is 


\section{Masquerades and Disguises}

a twig of ivy. The branch to the right is the real twig: observe its buds and the scars at the bases of the fallen leaf-stalks. Then look at the twig to the left, which is really the caterpiliar, with form and colour cunningly devised to imitate exactly the true twig beside it. He holds on by his hind legs, and sticks his body out from the stem, in a rigid attitude, at the appropriate angle; a knob on his side minics the scars of the fallen leaves, while the turn of his head and neck exactly reproduces the terminal bud on the real ivybranch. This admirable insect-actor, Mr. Enock tells me, has often imposed even on the artist who here paints his portrait.

A slightly different specimen of the same class of deception is given

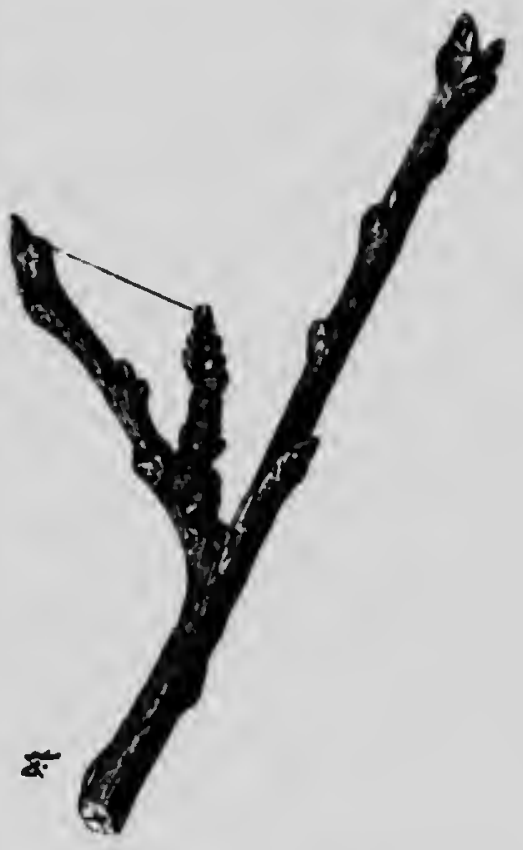

NO. I1.-CATERPILLAR OF THE THORN MOTH, PRETENDING TO BE A TWIG OF HAWTHORN. in No. II, which is the likeness of the caterpillar who turns into the thornmoth. Only a very keen eye can detect a welldisguised grub like this on a knotty branch of its native food-plant.

No. I2 is a common example of the group of 
stick-insects, allies of the grasshoppers, crickets, and locusts, a tribe among which the resemblance to leaves and twigs is carried further than in any other instance. This particular stick-insect does

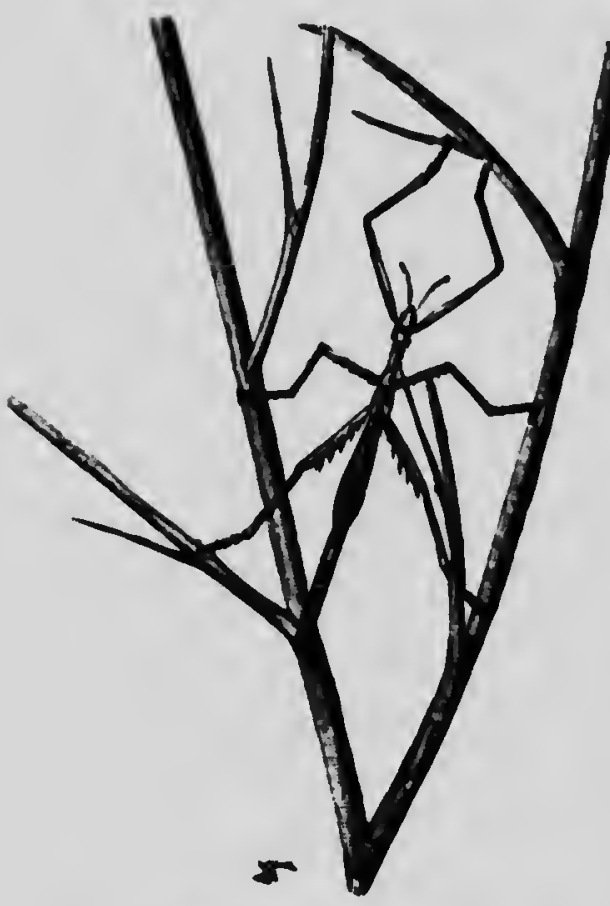

NO. 12.-COMMON STICK - INSECT, I.OST AMONG THE TIICKET OF TWIGS WIICH IE IMITATES. not look very much disguised in the sketch, it is true ; but then, you must remember that colour counts for half the battle in all these cases; and I have not yet ventured to ask for coloured illustrations. I know the stick-insects well, however, in many parts of the world -I was "raised" on them in Canada -and I know that they are often most difficult of detection. Sherlock Holmes himself would sometimes find them very hard cases. It has happened to me more than once to stand gazing for some minutes into a bush in search of them, and find none : suddenly, a slight movement somewhere would arrest my attention : and then, all at once, 


\section{Masquerades and Disciuises}

the twig at which I had been gazing with rapt attention would get up and walk away in the most leisurely and lordly fashion. Stick-insects are slow and inactive creatures: they sleep by day, and wander forth by night to feed on leaves, for, like Mr. Bernard Shaw, they are strict vegetarians.

Only those who have looked close into tropical jungles or into English hedgerows, with long and careful scrutiny, can realise the large part which such disguises play in the balanced and complicated scheme of uature. Unobservant people are apt to disbelieve in them. For, naturally, unob. servant people see only the obvious: most of the birds and animals they know are just the protected ininority which have bright warning colours, or are courageous ellough and strong enough to dare to be conspicuous. But the world about us teems with unobtrusive, skulking life : and this skulking life, in many ways the most curinus and interesting $f-11$, is unknown save to the naturalist. I hope \& nay have succeeded here in unmasking the disguises of some few among these countless natural masyueraders, and that a proportion of my readers at least may be led by my remarks to look a little more closely into that glorious and profoundly absorbing panorama which nature unfolds, free of charge, before our eyes every morning. Barnum's show, indeed! Why, nature can give Mr. Barnum, his heirs, executors, and assignees, ninety-nine points in every game, and "beat him, ensy !" 


\section{V}

\section{SOMLE STKANGE NURSERIES}

170

OU could hardly find a better rough test of relative development in the animal (or vegetable) world than the number of young pro. duced and the care bestowed upon them. The fewer the offspring, the higher the type. Very low animals turn out thousands of eggs with reckless profusion ; but they let them look after theinselves, or be devoured by enemies, as chance will have it. The higher you go in the scale of being, the smaller the families, but the greater the amount of pains expended upon the rearing and uphringing of the young. Large broods mean low urganisation; small broods imply higher types and more care in the nurture and education of the offspring. Primitive kinds produce eggs wholesale, on the off chance that some two or three among them may perhaps survive an infant mortality of 99 per cent., so as to replace their pirents : advanced kinds produce half-a-dozen young, or less, but bring a large proportion of these on an average up to years of discretion.

Without taking into account insects and such other small deer, this fundamental principle of population will become at once apparent if we 
examine merely familiar instances of back-boned or vertebrate animals. The lowest vertebrates are clearly the fishes: and fish have almost invariably gigantic families, especially in the lower orders of the race. A single cod, for example, is said to produce, roughly speaking, nine million eggs at a birth (I cannot pretend I have checked this calculation); but supposing they were only a million, and that one-tenth of those eggs alone ever cante to maturity, there would still be a hundred thousand codfish in the sea this year for every pair that swam in it last year: and these wonld increase to a hundred thousand times that number next year: and so on, till in four or five years' time the whole sea would be but one solid mass of closely-packed cod-banks. We can see for ourselves that nothing of the sort actually occurs - practically speaking, there are about the same number of cod one year as another. In spite of this enormous birth-rate, therefore, the cud population is not increasing-it is at a standstill. What does that imply? Why, that taking one brood and one year with another, only a pair of cod, roughly speaking, survive to maturity out of each eight or nine million eggs. The mother cod lays its millions, in order that two may arrive at the period of spawning. All the rest get devoured as eggs, or snapped up as young fry, or else die of starvation, or are otherwise unaccounted for. It seems to us a wasteful way of replenishing the earth: but it is nature's way; we can only bow respectfully to her final decision. 
Frogs and other amphibians stand higher in the scale of life than fish: they have acquired legs in place of fins, and lungs instead of gills; they can hop about on shore with perfect freedom. Now, frogs still produce a great deal of spawn, as every one knows : but the eggs in each brood are numbered in their case by hundreds, or at most by a thousand or two, not by millions as with many fishes. The spawn hatches out as a rule in ponds, and we have all seen the little black tadpoles crowding the edges of the water in such innumerable masses that one would suppose the frogs to be developed from them inust cover the length and breadth of England! Yet what becomes of thein all ? Hundreds are destroyed in the early tadpole stage - eaten up or starved, or crowded out for want of air and space and water: a few alone survive to develop four legs and absorb their tails and hop on shore as tiny froglins. Even then the massacre of the innocents continues: only a tithe of those which succeed in quitting their native pond ever return to it full grown, to spawn in due time and become the parents of further generations.

Lizards and other reptiles make an obvious advance on the frog type : they lay relatively few eggs, but they begin to care for their young: the family is not here abandoned at birth, as among frogs, but is frequently tended and fed and overlooked by the mother. In birds we have a still higher development of the same marked parental tendency; only three or four eggs are laid each year, as a rule, and on these eggs the mother sits, while 
both parents feed the callow nestlings till such time as ther: ar: abie to take care of themselves and pick up thr ir own living, Among mammals, which stand undou intuly at the sead of created nature, the lower types, isk wice and rabbits, have frequent broods of many young at a time; but the more advanced groups, such as the horses, cows, deer, and elephants, have usually one foal or calf at a birth, and seldom produce more than a couple. Moreover, in all these $\mathrm{t}$. gher cases alike, the young are fed with milk by the mother, and so spared the trouble of providing for themselves in their early days, like the young codfish or the baby tadpole. Starvation at the outset is reduced to a minimum.

It is interesting to note, too, that anticipations of higher types, so to speak, often occur among lower races. An animal here and there among the simpler forms hits upon some device essentially similar to that of some higher group with which it is really quite unrelated. For example, those who have read my account of the common earwig (given in the sixth chapter of "Flashlights on Nature") will recollect how that lowly insect sits on her eggs exactly like a hen, and brings up her brood of callow grubs as if they were chickens. In mucl the same way, anticipations of the mammalian type occur pretty frequently among lower animals. Our commonest English lizard, for example, which frequents moors and sandhills, does not lay or deposit its eggs at all, but hatches them out in its own body, and so apparently brings them forth alive: while among snakes, the same habit 
occurs in the adder or viper. The very name viper, indeed, is a corruption of vivipara, the snake which produces living young. Still more closely do some birds resemble mammals in the habit of secreting a sort of milk for the sustenance of their nestlings. Most people think the phrase "pigeon's milk" is much like the phrase "the horse-marines," a burlesque name for an absurd and impossible monstrosity. But it is nothing of the sort : it answers to a real fact in the economy of certain doves, which eat grain or seeds, grind and digest it in their own gizzards into a fine soft pulp or porridge, and then feed their young with it from their crops and beaks. This is thus a sort of bird-like imitation of milk. Only, the cow or the goat takes grass or leaves, chews swallows, and digests them, and manufactures from them in her own body that much more nutritive substance, milk, with which all mammals feed their infant offspring.

Now, after this rather long preamble, I am going to show you in this present article a few other examples of special care taken of the young in certain quarters where it might be least expected. Fish are not creatures from which we look for marked domestic virtues: yet we may find them there abundantly. Let us begin with that familiar friend of our childhood, the common English
stickleback.

Which of us cannot look back in youth to the mysteries of the stickleback fisheries? Captains courageous, we sallied forth with bent pin and piece of thread, to woo the wily quarry with half 
an inch of chopped earthworm. For stickleback abound in every running stream and pond in England. They are beautiful little creatures, too, when you come to examine them, great favourites in the fresh-water aquarium; the male in particular is exquisitely coloured, his hues growing brighter and his sheen more conspicuous at the pairing season. There are many species of sticklebacksin England we have three very different kindsbut all are alike in the one point which gives them their common name, that is to say, in their aggressive and protective prickliness. They are armed against all comers. The dorsal fin is partly replaced in the whole family by strong spines or "stickles," which differ in number in the different species. One of our English sorts is a lover of salt water : he lives in the sea, especially off the Cornish coast, and has fifteen stickles or spines : on which account he is commonly known as the Fifteenspined Stickleback : our other two sorts belong to fresher waters, and are known as the Ten-spined and the Three-spined respectively.

The special peculiarity of the male stickleback consists in the fact that he is, above all things, a model father. In his acute sense of parental responsibility he has few equals. When spring comes round, he first exhibits his consciousness of his coming charge by suddenly enduing himself in a glowing coat of many colours and of iridescent brilliancy. That is in order to charm the eyes of his prospective mate, or rather mates, for I may as well confess the sad truth at once that our amiable 


\section{IN NATURE'S WORKSHOP}

friend is a good parent but an abandoned polygamist. We all know that

"In the spring a fuller crimson comes upon the robin's breast ; In the spring the wanton lapwing gets himself another crest ; In the spring a livelier iris changes on the burnish'd dove ; In the spring a young man's fancy lightly turns to thoughts of love."

Not to be out of the fashion, therefore, the romantic stickleback does precisely the same thing as all these distinguished and poetical compeers. And he does it for the same reason too: because he wants to get himself an appropriate partner. "There is a great deal of human nature in man," it has been said: I am always inclined to add, "And there is a great deal of human nature in plants and animals." The more we know of our dumb relations, the more closely do we realise the kinship between us. Fish in spring are like young men at a fair-all eager for the attention of their prospective partners.

The first care of the male stickleback, when he has acquired his courting suit, is to build a suitable home for his future wives and children. So he picks up stems of grass and water-weeds with his mouth, and weaves them deftly into a compact nest as perfect as a bird's, though somewhat different in shape and pattern. It rather resembles a barrel, open at both ends, as though the bottom were knocked out : this form is rendered necessary because the eggs, when laid, have to be constantly aërated by passing a current of water through the nest, as I shall describe hereafter. No. I shows us such a nest when completed, with the female stickle- 
back loitering about undecicled as to whether or not she shall plunge and enter it. You will observe that the fabric is woven round a fixed support of some waving waterweeds; but the cuining little architect does not trust in this matter to his textile skill alone; he cements the straws and other materials together with a gummy mortar of mucous threads, secreted for thepurpose by his internal organs.

As soon as the building operations are f u 11 y completed, the

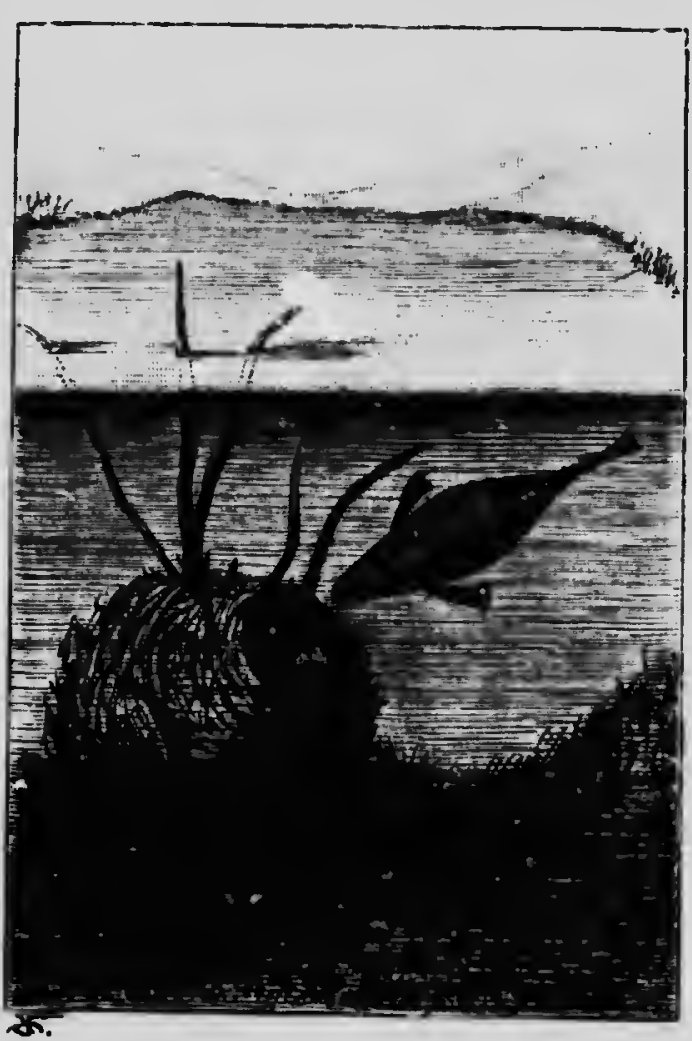

NO. I. -STICKLEB.ICK'S NEST : THE MOTHER ABOUT TO F.NTEK. eager little householder sallies forth into his pond or brook in search of a mate who will come and stock his neatly-built home for him. At this stage of the proceedings, his wedding-garment becomes 
even more brilliant and glancing than ever; he gleams in silver' and changeful gems: when he finds his lady-love, he dances round her, "mad with excitement," as Darwin well phrased it,

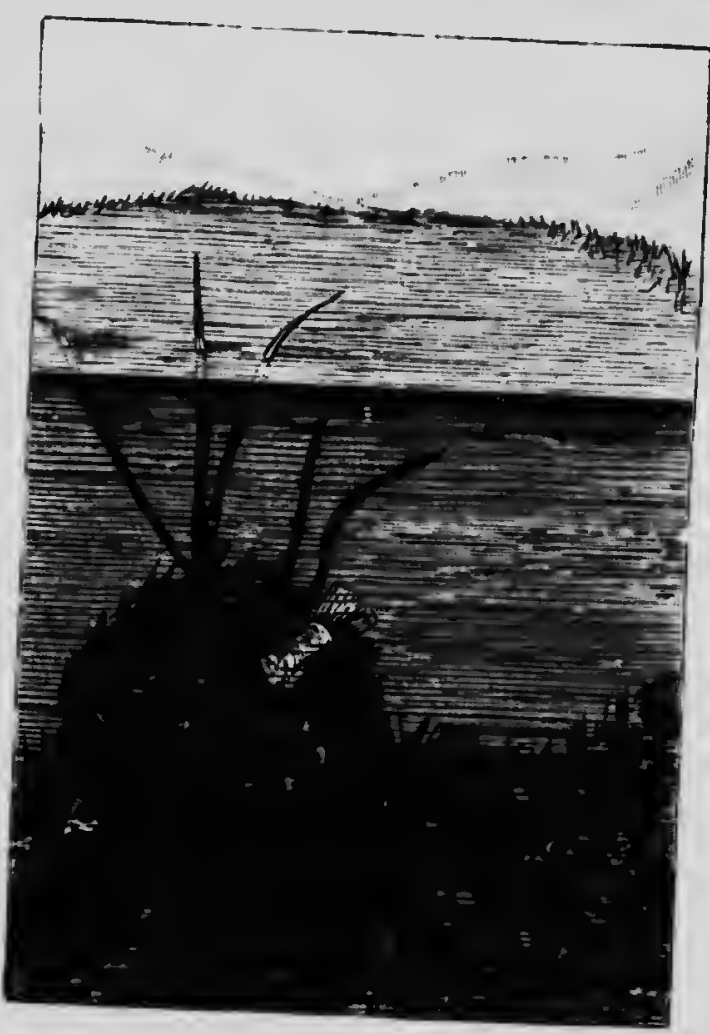

NO. 2.-THE MOTHER I.AYING THE EGGS. looking his hand somest and best with his lustrous colours glistening like an opal. If she will listen to his suit, he grows wild with delight, and coaxes her into the nest with most affectionate endearments. In No. 2, as you perceive, the mate of his choice has been induced to enter, and is laying her eggs in the dainty home his care has provided for her. The father fish, meanwhile, dances and capers around, in a pas de triomphe at the success of his endeavours.

One wife, however, does not suffice to fill the nest with eggs: and the stickleback is a firm believer in 
the advantages of large families. So, as soon as his first mate has laid all her spawn, he sets out once more in search of another. Thus ine goes on until the home is quite full of eggs, bringing back one wife after another, in proportion to his success in wooing and fighting. For, like alnost all polygamists, your stickleback is a terrible fighter. The males join wager of battle with one another for possession of their mates; in their fierce duels they make fearful use of the formidable spines on their backs, sometimes entirely ripping up and cutting to pieces their ill-fated adversary. The spines thus answer to the spurs of the game-cock or the antlers of the deer; they are masculine weapons in the struggle for mates. Indeed, you may take it for granted that brilliant colours and decorative adjuncts in animals almost invariably go with irascible tempers, pugnacious habits, and the practice of fighting for possession of the harem. The consequence is, with the sticklebacks, that many males get killed during the struggle for supremacy, so that the survivors wed half-a-dozen wives each, like little Turks that they are in their watery seraglios. Only the most beautiful and courageous fish succeed in gaining a harem of their own : and thus the wager of battle tells in the end for the advantage of the race, by eliminating the maimed, the ugly, and the cowardly, and encouraging the strong, the handsome, the enterprising, and the valiant. This is nature's way of preventing degeneracy.

In No. 3 the nest is seen full of eggs, and the 
126

\section{IN Natuke's WORKSHOP}

excellent father now comes out in his best light as their guardian and protector. He watches over them with ceaseless care, freeing them from parasites, and warding off the attacks of would-be

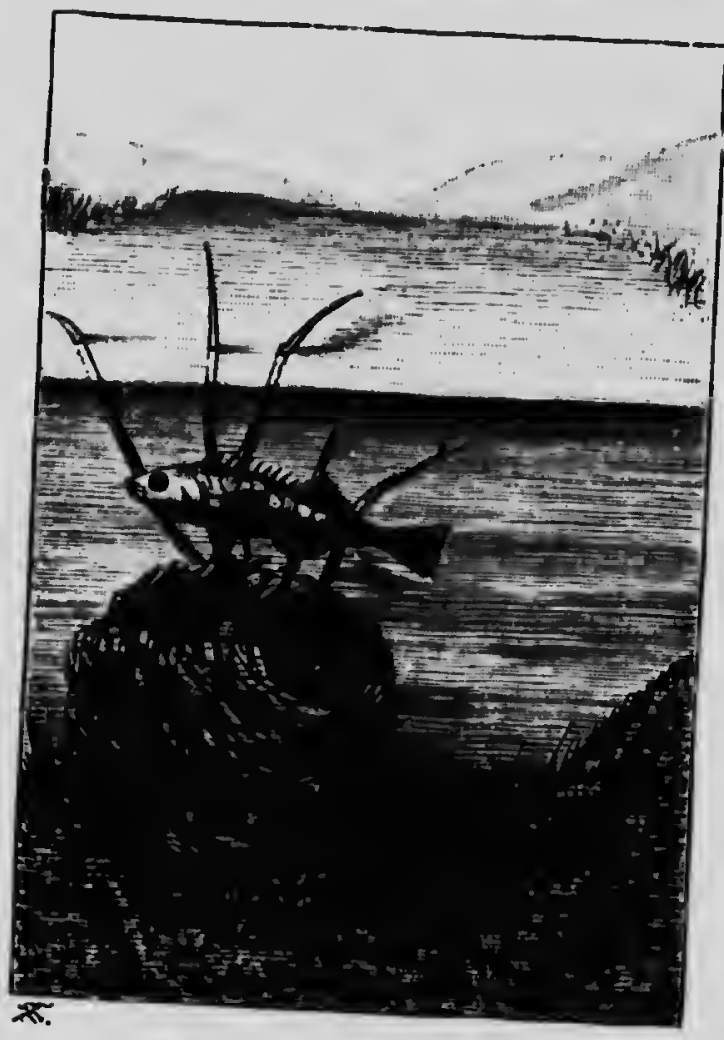

NO. 3.-TIIE FATHER STICKILBACK AIRING THE EGGS. enemies who desire to devour them, even though the intruder be several times his own size. The spines on his back here stand him once more in good stead : for small as he is, the stickleback is not an antagonist to be lightly despised : he can inflict a wound which a perch or a trout knows how to estimate at its full value. But that is not all the good parent's duty. He takes the eggs out of the nest every now and then with his snout, airs them a little in the fresh water outside, and then replaces and rearranges 
them, so that all may get a fair share of oxygen and may hatch out about simultaneously. It is this question of oxygen, indeed, which gives the father fish the greatest trouble. That necessary of life is issolied in water in very small quantities: and it is absolutely needed by every egg in order to enable it to unclergo those vital clanges which we know as hatching. To keep up a due supply of oxygen, therefore, the father stickleback ungrudgingly devotes laborious days to poising himself delicately just above the nest, as you see in No. 3 , and famning the eggs with his fins and tail, so as to set up a constant current of water through the centre of the barrel. He sits upon the eggs just as truly as a hen cloes: only, he sits upon them, not for warmth, but for ä̈ration.

For weeks together this exemplary parent continues his monotonous task, ventilating the spawn many times every day, till the time comes for hatching. It takes about a month for the eggs to develop; and then the proud father's position grows more arduous than ever. He has to rock a thousand cradles at once, so to speak, and to pacify a thousand crying babies. On the one hand, enemies hover about, trying to eat the tender transparent glass-like little fry, and these he must drive off : on the other hand, the good nurse must tike care that the active young fish do not stray far from the nest, and so expose themselves prematurely to the manifold dangers of the outer world. Till they are big enough and strong enough to take care of themselves, he watches with incessant vigilance 
over their safety; as soon as they can go forth with tolerable security upon the world of their brook or pond, he takes at last a well-merited holiday.

It is not surprising under these circumstances to learn that sticklebacks are successful and increasing animals. Their numbers are enormous, wherever they get a fair chance in life, because they multiply rapidly up to the extreme limit of the means of subsistence, and develop as fast as food remains for them. There the inexorable Malthusian law at last steps in: when there is not food enough for all some must istarve: that is the long and the short of the great population question. But while provender is forthcoming they increase gaily. Sticklebacks live mainly on the spawn of other fish, though they are so careful of their own, and they are therefore naturally hated by trout-preservers and owners of fisheries in general. Thousands and thousands are caught each year; in some places, indeed, they are so numerous that they are used as manure. It is their numbers, of course, that make them formidable : they are the locusts of the streams, well armed and pugnacious, and provided with most remarkable parental instincts of a protective character, which enable them to fill up all vacancies in their ranks as fast as they occur with astonishing promptitude.

To those whose acquaintance with fish is mainly culinary, it may seem odd to hear that the father stickleback alone takes part in the care of the nursery. But this is really the rulc among the 
whole class of fish: wherever the young are tencled, it is almost always the father, not the mother, who unclertakes the duty of incubation. Only two instances occur where the female fish assumes maternal functions towards her young: about these I shall have more to say a little later on. We must remember that reptiles, birds, and mammals are in all probability descended from fish as ancestors, and it is therefore clear that the habit of handing over the care of the young to the female alone belongs to the higher grades of vertebratesin other words, is of later origin. We need not be astonished, therefore, to find that in many cases among birds and other advanced vertebrates a partial reversion to the earlier habit not infrequently takes place. With doves, for example. the cock and hen birds sit equally on the eggs, taking turns about at the nest; and as for the ostriches, the male bird there does most of the incubation, for he accepts the whole of the night duty, and also assists at intervals during the daytime. There are numerous other cases where the father bird shares the tasks of the nursery at least equally with the mother. I will glance first, however, at one of the rare exceptions among fish where the main duty does not devolve on the devoted father.

In No. 4 we have an illustration of the tubemouth or Solenostoma, one of the two known kinds of fish in which the female shows a due sense of her position as a mother. The tuhemouth, as you can see at a glance, is a close 
relation of our old friend the sen-horse, whose disguised and unclisguised forms in Australia and the Mediterranean we have already observ of when dealing with the question of animal masqueraders. Solenostoma is a native of the Indian Ocean, from Zanzibar to China, and in real life is about double

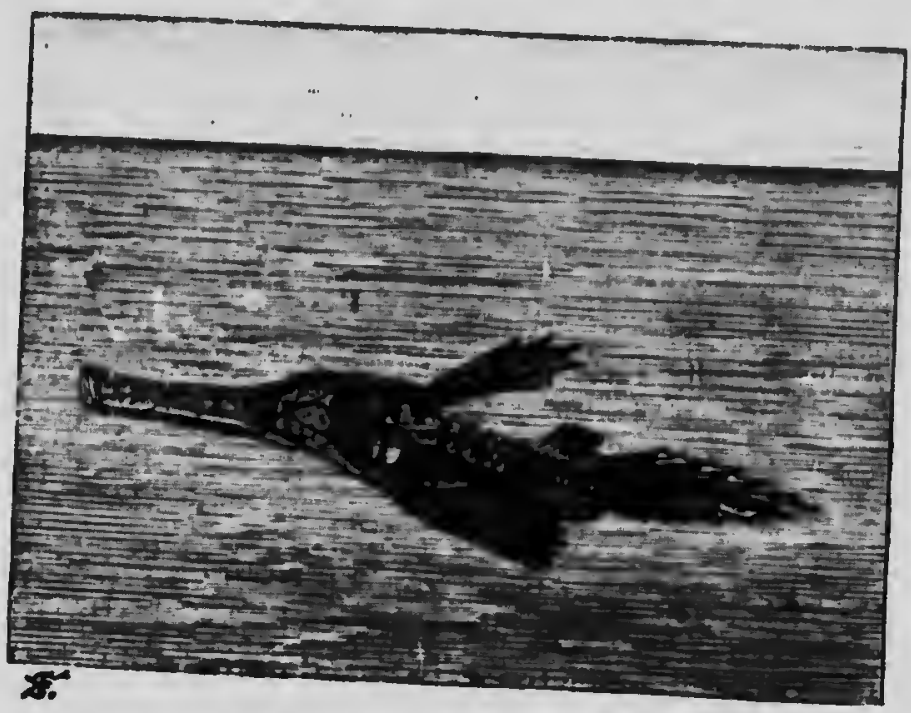

NO. 4.-THE MOTHER TUBE-MOUTH CARRYING HER EGGS IN A POUCH.

the size of Mr. Enock's drawing. In the male, the lower pair of fins are separate, as is usual among 6- $h$ : but in the female, represented in the accompanying sketch, tlicy are lightly joined at the edge, so as to form a sort of pouch like a kangaroo's, in which the eggs are deposited after being laid, and thus carried about in the mother's safe keeping. No. 5 shows the arrangement of this pouch ir: 
detail, with the eggs inside it. The mother Solenostoma not only takes charge of the spa: $n$ while it is hatching in this receptacle, but also looks after the young fry, like the father stickleback, till they are of an age to go off on their ow'n account in quest of adventures. The most frequent adventure that happens to them on the way is, of course, being eaten.

Our own common English pipe-fish is a good example of the other and much more usual case in which the father alone is actuated by a proper sense of parental responsibility. The pipe-fish, indeed, might almost be described as a pure and blameless ratepayer. No. 6 shows you the outer form of this familiar creature, whom you will recognise at a glance as still more nearly allied to the sea-horses than even the tubemouth. Pipe-fishes are timid and skulking creatures. Like their horse-headed no. 5.-Tu: relations, they lurk for the most part among seaweed for protection, and, THE EGGS being but poor swimmers, never ven-

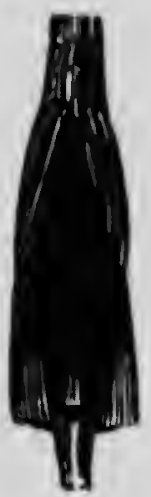
ture far from the covering shelter of their native thicket. But the curious part of them is that in this family the father fish is provided with a pouch even more perfect than that of the female tube-mouth, and that he himself, not his mate, takes sole charge of the young, incubates them in his sack, and escorts them about for some time after hatching. The pouch, which is more 
fully represented in No. 7 , is formed by a loose fold of skin arising from either side of the creature. In the illustration this fold is partly withdrawn, so as to show the young pipe-fish within their safe retreat after hatching out. It is said, I know not how truly, that the young fry will stroll out for an

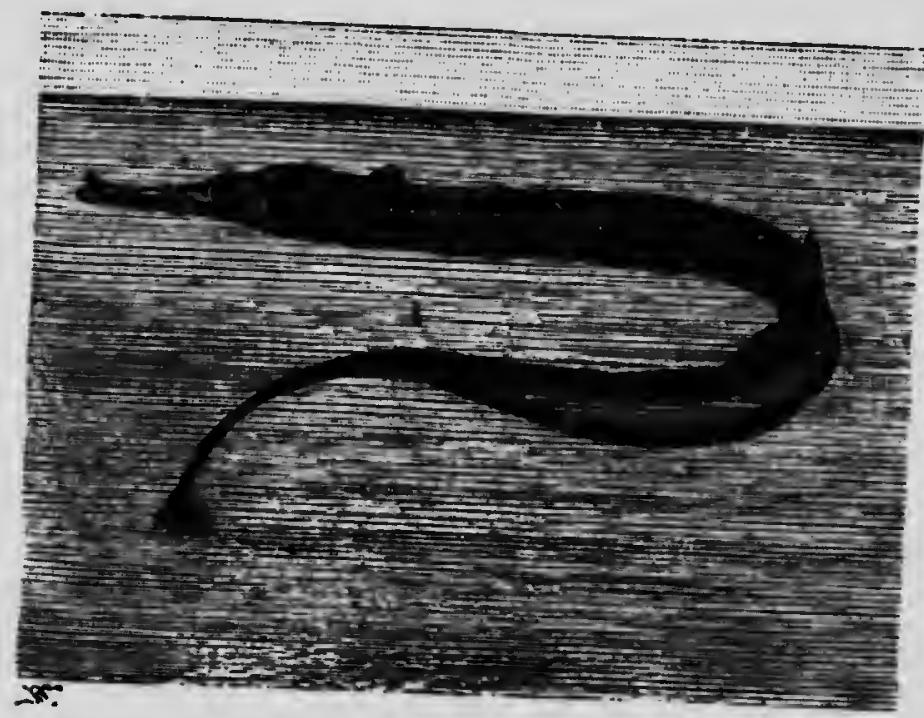

NO. 6.- TIIE FATHER PIPE.FISH, CARRYING UIS YOUNG IN A pouch.

occasional swim on their own account, but will return at any threat of danger to their father's bosom, for a considerable time after the first hatching. This is just like what one knows of kangaroos and many other pouched mammals, where the mother's pouch becomes a sort of nursery, or place of refuge, to which the little ones return for warmth or safety after every excursion. 
The sea-horses and many other fish have similar pouches; but, oddly enough, in every case it is the male fish which bears it, and which undertakes the ardious duty of nurse for his infant offspring.

A few female fish, on the other hand, even hatch the eggs within their own bodies, and so apparently bring forth their young alive, like the English lizard among reptiles. This, however, is far from a common case : indeed, in an inmense number of instances, neither parent pays the slightest attention to the eggs after they are once laid and got rid of :

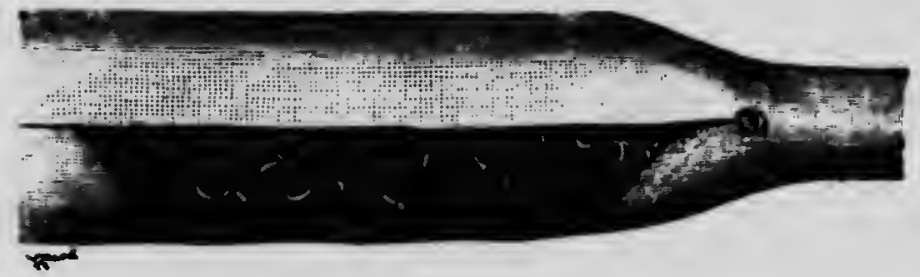

No. 7.-THE pouch hal.p OPENeD, to show THE younc.

the spawn is left to lie on the bottom and be eaten or spared as chance directs, while the young fry have to take care of themselves, without the aid of parental advice and education. But exceptions occur where both parents show signs of realising the responsibilities of their position. In some little South American river fish, for instance, the father and mother together build a nest of dead leaves for the spawn, and watch over it in unison till the young are hatched. This case is exactly analogous to that of the doves among birds: I may add that wherever such instances occur they always seem to 
be accompanied by a markedly gentle and affectionate nature. Brilliantly-coloured fighting polygamous fishes are fierce and cruel : monogamous and faithful animals are seldom bright-hued, but they mate for life and are usually remarkable for their domestic felicity. The doves and love-birds are familiar instances.

Frogs are very closely allied to fish : indeed, one may almost say that every frog begins life as a fish, limbless, gill-bearing, and aquatic, and ends it as something very like a reptile, four-legged, lungbearing, and more or less terrestrial. For the tadpole is practically in all essentials a fish. It is not odd, therefore, to find that certain frogs reproduce, in a very marked manner, the fatherly traits of their fish-like ancestors. There is a common kind of frog in France, Belgium, and Switzerland, which does not extend to England, but which closely recalls the habits of the stickleback and the pipe-fish. Among these eminently moral amphibians, it is the father, not the mother, who takes entire charge of the family-wheels the perambulator, so to speak. The female lays her spawn in the shape of long strings or rolls of eggs, looking at first sight like slimy necklaces. I have seen them as much as a couple of yards long, lying loose on the grass where the frog lays them. As soon as she has deposited them, however, the father frog hops up, twists the garlands dexterously in loose festoons round his legs and thighs, and then retires with his precious burden to some hole in the bank of his native pond, where he lurks in seclusion till the 
eggs develop. Frogs do not need frequent doses of food-their meals are often few and far between -and during the six or eight weeks that the eggs take to mature the father probably eats very little, though he may possibly sally forth at night, unobserved, in search of provender. At the end of that time the devoted parent, foreseeing developments, takes to the water once more, so that the tadpoles may be hatched in their proper element. I may add that this frog is a great musician in the breeding season, but that as soon as the tadpoles have hatched out he loses his voice ntirely, and does not recover his manly croak till the succeeding spring. This is also the case with the song of many birds, the crest of the newt, the plumes of certain highly-iecorated trogons and nightjars, and, roughly speaking, the decorative and attractive features of the male sex in general. Such features are given thein during the mating period as allurements for their consorts : they disappear, for the time at least, like a ball-dress after a ball, as soon as no immediate use can any longer be made of them.

Some American tree-frogs, on the other hand, imitate rather the motherly Solenostoma than the fatherly instincts of the pipe-fish or the stickleback. These pretty little creatures have a pouch like the kangaroo, but 111 their case (as in the kangaroo's) it is the female who bears it. Within this safe receptacle the eggs are placed by the male, who pushes them in with his hind feet; and they not only undergo their hatching in the pouch, but also pass through their whole tadpole development in 
the same place. Owing to the care which is thus extended to the eggs and young, these advanced tree-frogs are enabled to lay only about a dozen to fifteen eggs at a time, instead of the countless hundreds often produced by many of their relations.

Tree-frogs have, of course, in most circumstances much greater difficulty in getting at water than pond-frogs; and this is especially true in certain tropical or desert districts. Hence most of the frogs which inhabit such region, have had to find out or invent some ingenious plan for passing through the tadpole stage with a minimum of moisture. The devices they have hit upon are very curious. Some of them make use of the little pools collected at the bases of huge tropical leafstalks, like those of the banana plant; others dispense with the aid of water altogether, and glue their new-laid eggs on their own backs, where the fry pass through the tadpole stage in the slimy mucus which surrounds them. Nature always discovers such cunning schemes to get over apparent difficulties in her way : and the tree-frogs have solved the problem for themselves in half-adozen manners in different localities. Oddest of all, perhaps, is the dodge invented by "Darwin's frog," a Chilian species, in which the male swallows the eggs as soon as laid, and gulps them into the throat-pouch beneath his capacious neck: there they hatch out and pass through their tadpole stage: and when at last they arrive at frogly maturity, they escipe into the world through the 
The Surinam toad, represented in No. 8 , is also the possessor of one of the strangest nurseries known to science. It lives in the dense tropical forests of Guiana and Brazil, and is a true waterhaunter. But at the breeding season the female

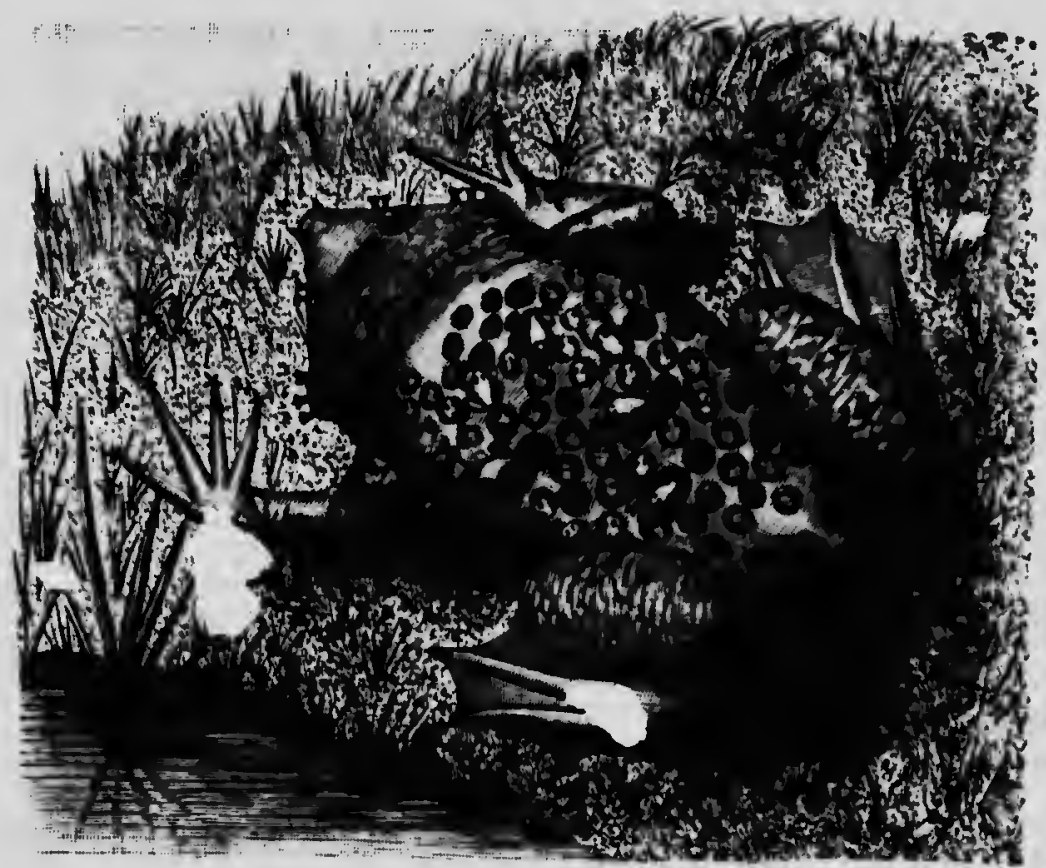

NO. 8. -SURINAM TOAI), CARRYIN(; HER FAMILY.

undergoes a curious change of integument. The skin on her back grows pulpy, soft, and jelly-like. She lays her eggs in the water: but as soon as she has laid them, her lord and master plasters them on to her impressionable back with his feet, so as to secure them from all assaults of enemies. Every 


\section{IN NATURE'S WORKSHOP}

egg is pressed separately into a bed of the soft skin, which soon closes over it automatically, thus burying each in a little cell or niche, where it undergoes its further development. The tadpoles pass through their larval stage within the cell, and then hop out, as the illustration shows, in the fourlegged condition. As soon as they have gone off to shift for themselves, the mother toad finds herself with a ragged and honeycombed skin, which must be very uncomfortable. So she rubs the remnant of it off against stones or the bark of trees, and redevelops a similar back afresh at the next breeding season.

Almost never do we'find a device in nature which occurs once only. The unique hardly exists : nature is a great copyist. At least two animals of wholly unlike kinds are all but sure to hit independently upon the self-same mechanism. So it is not surprising to learn that a cat-fish has invented an exactly similar mode of carrying its young to that adopted by the Surinam toad: only, here it is on the under surface, not the upper one, that the spawn is plastered. The eggs of this cat-fish, whose scientific name is Aspredo, are pressed into the skin below the body, and so borne about by the mother till they hatch. This is the second instance, of which I spoke above, where the female fish herself assumes the care of her offspring, instead of leaving it entirely to her excellent partner.

Higher up in the scale of life, we get many instances which show various stages in the same progressive development towards greater care for 
the safety and education of the young. Among the larger lizards, for example, a distinct advance may be traced between the comparatively uncivilised American alligator and his near ally, the much more cultivated African crocodile. On the banks of the Mississippi, the alligator lays a hundred eggs or thereabouts, which she deposits in a nest near the water's edge, and then covers them up with leaves and other decaying vegetable matter. The fermentation of these leaves produces heat, and so does for the alligator's eggs what sitting does for those of hens and other birds : the mother deputes her maternal functions, so to speak, to a festering heap of decomposing plant-refuse. Nevertheless, she loiters about all the time, like Miriam round the ark which contained Moses, to see what happens; and when the eggs hatch out, she leads her little ones down to the river, and there makes alligators of them. This is a simple and relatively low stage in the nursery arrangements of the big lizards.

The African crocodile, on the other hand, goes a stage higher. It lays only about thirty eggs, but these it buries in warm sand, and then lies on top of them at night, both to protect them from attack and to keep them warm during the cooler hours. In short, it sits upon them. When the young crocodiles within the egg are ready to hatch, they utter an acute cry. The mother then digs down to the eggs, and lays them freely on the surface, so that the little reptiles may have space to work their way out unimpeded. This they do by biting at the shell with a specially developed tooth; at 
the end of two hours' nibbling they are free, and are led down to the water by their affectionate parent. In these two cases we see the beginnings of the instinct of hatching, which in birds, the next in order in the scale of being, has become almost universal.

I say almost universal, because even among birds there are a few kinds which have not to this day progressed beyond the alligator level. Australia is the happy hunting-ground of the zoologist in search of antiquated forms, elsewhere extinct ; and several Australian birds, such as the brush-turkeys, still treat their eggs essentially on the alligator method. The cock hirds heap up huge mounds of earth and decaying vegetable matter, as much as would represent several cartloads of mould; and in this natural hot-bed the hens lay their eggs, burying each separately with a good stock of leaves around it. The heat of the sun and the fermenting mould hatch them out between them; to expedite the process, the birds uncover the eggs during the warmer part of the day, expose them to the sun, and bury them again in the hot-bed towards evening. Several intermediate steps may also be found between this early stage of communal nesting by proxy and the true hatching instinct; a good one is supplied by the ostrich, which partially buries its eggs in hot sand, but sits on them at intervals, both father and mother birds taking shares by turn in the duties of incubation.

The vast subject which I have thus lightly skimmed is not without interest, again, from its 
human implications. Savages as a rule produce enormous families; but then, the infant mortality in savage tribes is proportionately great. Among civilised races, families are smaller, and deaths in infancy are far less numerous. The higher the class or the natural grade of a stock, the larger as a rule the proportion of children safely reared to the adult age. The goal towards which humanity is slowly moving would thus seem to be one where families in most cases will be relatively smalperhaps not more on an average than three to a household-but where most or all of the children brought into the world will be safely reared to full maturity. This is already becoming the rule in certain favoured ranks of European society.

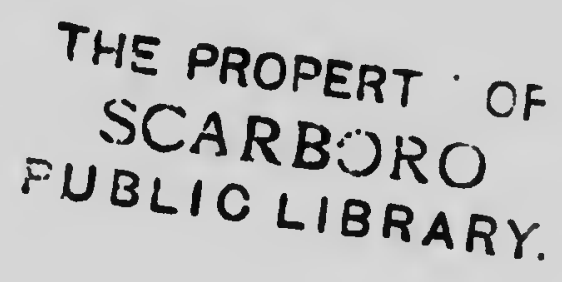




\section{VI}

ANIMAL AND VEGETABLE HEDGEHOGS

$M$

AN was not the first inventor of coats of mail and ironclads. 'Two types of defensive armour are common in nature. The first type almost exactly resembles the jointed plate. armour of mediaval knighis: one sees this kind well exemplified in the armadillo and the lobster; a little less well in the tortoise, the beetle, and many hard-shelled insects. The second type has no exact human analogue : it is offensive and defensive at one and the same time; one sees it exhibited in the porcupine, the hedgehog, the bramble, the thistle, and an immense variety of other plants and animals. With this second group the armour consists, not of plates, but of prickly spines or thorns, which repel assailants by wounding the tender flesh of the mouth or lips. Such prickliness of surface is perhaps the commonest among all the protective devices invented by living creatures : it is remarkable for its universal diffusion both in various countries and in various classes. There are insect hedgehogs and vegetable porc ipines. Indeed, scarcely a great order of plants or animals can be named which does not contain at least one or two such prickly or thorny species. 


\section{Animai and Vegetable Hedgehogs 143}

The common English hedgehog (shown in No. 1 in two characteristic attitudes) makes a good example of the prickly-irmoured class with which to begin the examination of this interesting series. Everybody is tolerably familiar with the hedgehog's appearance - a squat, square, inquisitive little creature, one of nature's low comedians, with very

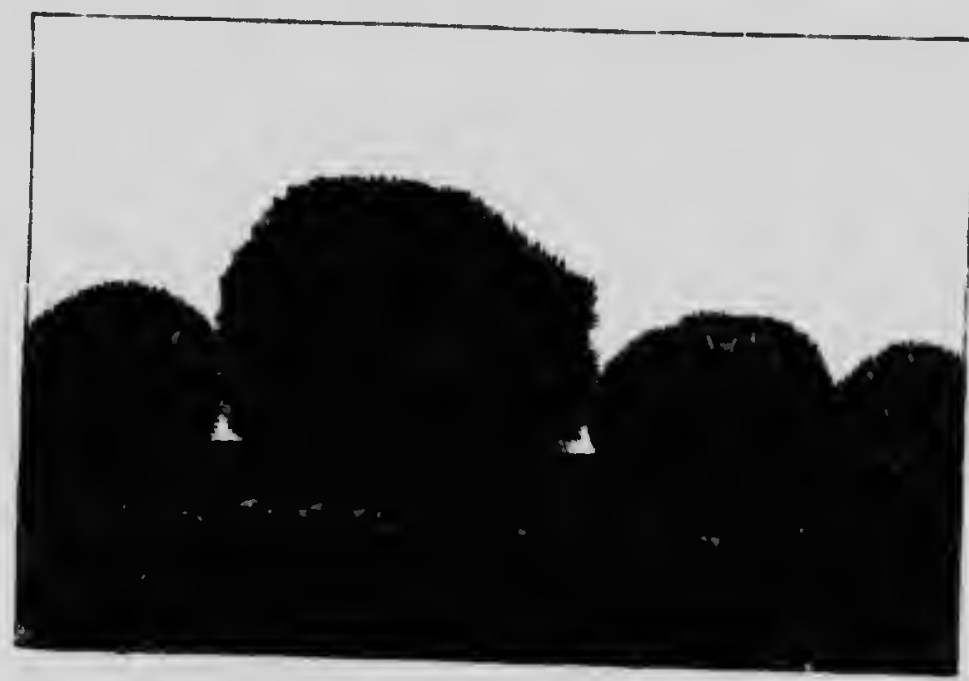

Nก. 1.-HEDGEHOGS, ROLLED AND UNRULLED.

short legs and no tail to speak of, but $\mathrm{c}^{-r}$ ered on his back and upper surface with dirty white spines, which merge more or less into indefinite blackness. But if he is comic to us, he is serious to himself. Slow and sedate in all his movements, your hedgehog seldom does anything so undignified as to run : to say the truth, he is a poor racer; he is not built for haste, but strolls calmly along on his bandy legs, 
showing little sense of fear even when surprised on the open, for he is well aware that his coat of spines amply suffices to secure him from aggression. The hare trusts to his speed, the rabbit to his burrow; but the hedgehog relies upon his prickles for protection, and scorns to flee when he can oppose to every foe an effective passive resistance. His bright, beady black eyes form his one claim to beauty : they gleam with cunning : save for them, he is a dingy and unattractive animal. But though he belongs to a very ancient and lionourable family -that of the insect-eaters-long since superseded in most of the high places of the earth by younger and more advanced types, he still manages to hold his own in the struggle for life against all com. petitors, mainly by virtue of his excellent suit of spiny armour.

The hedgehog is, on the whole, a nocturnal animal, like most of this early group of insectivores to which he belongs. Now, as a class, the insectivores have been driven from the best positions in nature's hierarchy by the keen competition of the rodents, the ruminants, and the carnivores; they have been compelled to earn a precarious living in out-of-the-way corners by night prowling. They are the gipsies and tinkers, the tramps and beggars of the animal economy. Our English hedgehog, one of the luckiest members of this persecuted class, lives usually in some comfortable hole in a hedge or copse, and sleeps away the daytime in owl-like seclusion. When night comes, however, he sallies forth on the hunt, in search of 
Animal and Vegetable Hedulik is $1+5$

beetles and other hard-shelled insects, which form his staple diet, and for crushing which his solid set of grinders admirably adapts him. In winter, when insect food fails, he hibernates in his lair, rolling himself up in a thick blanket of dead leaves for warmth : his spines here stand him in good stead for a different function from that of mere defence, for he fastens the leaves on them as if they were pins, and so keeps himself warm and dry through the snows and frosts and rains of winter. He has a tramp's true instinct: he knows how to make the best of poor surroundings.

With the first genial showers of April, our prickly friend turns out once more, very thin and hungry, in quest of the insects which are then just emerging from their burst cocoons or their snug winter quarters. Often enough at this season he comes forth from his nest with a layer or two of leaves still impaled upon his prickles, in which condition he cuts a most quaint and amusing figure. Every evening he shuffles about awkwardly in search of his prey, which consists mainly of beetles, relieved by a pleasing variety of slugs, snails, worms, frogs, and young birds, as well as an occasional egg, and now and again a snake or a shrew-mouse. Though despised by man, in his own small hedgerow world he is an undisputed tyrant, and has few real enemies. Most higher animals are afraid to tackle him. A dog will just sniff at him with a dubious air of inquiry, but when the spines prick his tender nose, he draws back disgusted, and refuses to join battle with the uncanny, bow-legged creaturc. 
Indeed, the hedgehog's only serious foe is the owl, which has invented a special device for seizing him unawares. Almost all other mouse and rat-eating species fear to engage so well-armed an enemy.

The difficulty of the attack lies, of course, in his spines, a first line of defence, which one may regard as typical of the tactics adopted among the whole group of prickle-bearing animals. These spines are hard in texture, and very sharp at the point : cylindrical in shape, and an inch long or thereabouts. They are lightly embedded in the skin, and are so arranged that they can be erected at will into a most aggressive position. This trick of raising the spines is managed by an extremely interesting mechanism, something like the muscle by means of which certain gifted persons (chiefly schoolboys) can move and ruffle up the skin and hair of the head just above the temples, only on a much more extended scale of organisation. The set of muscles thus specialised enables the animal to curl itself about in the lithest fashion. When an enemy approaches, the hedgehog does not flinch: he simply rolls himself up into a round ball. The South American armadillo does much the same thing: only, when the armadillo is rolled up, he becomes a mere hard sphere, something like a bombshell: whereas the hedgehog becomes an unapproachable globe of fixed bayonets. He tucks his head and legs well out of harm's way under his lower surface, and exposes only the spiny upper portion of his back and body. A great band of specialised muscle, assisted by several subsidiary 


\section{Animal and Vegetable Hedgehogs I47}

belts, draws his supple skin tight over his whole body, and at the same time points the sharp ends of the spines radially outward. When a hedgehog is thus rolled up into his attitude of passive defence, no animal on earth can do anything with him in fair open fight, though some few of them have invented mean underhand tricks for getting round him by artifice. Most of these are too nasty for full description. Rolling him into water and drowning him is one of the least objectionable: but the method pursued by his chief human foe, the gipsy, though extremely criel, is so quaintly clever that it seems to deserve a passing mention.

$\mathrm{Gi}_{\mathrm{i}}$ ies never despise any form of wild food, and they have hit upon a perfidious dodge for utilising the hedgehog. They catch him alive, which is always easy enough : for the little beast, trusting to his array of spines, seldom runs away when attacked, but contents himself with rolling himself up into his spherical and apparently lifeless condition. The season for hedgehogs is at the end of autumn, when the animal has fattened himself for his winter sleep. Kneading a ball of moist clay, the gipsies embed the poor creature in it entire, so that spines and all are completely covered. Then they lay the ball in their fire, and roast the unhappy animal alive. As soon as the clay cracks, the hedgehog is cooked : they break the ball, and the skin comes off whole, spines, clay, and all, leaving the steaming hot body baked and savoury in the middle. I mention this curious but hateful trick because it is very characteristic of the sort of plan which many animals have 
adopted for getting rid of the spines or hairs in caterpillars and other protected but juicy creatures. What man does intelligently, that birds and quad. rupeds also do and did before him by inherited and acquired instinct.

When the little hedgehogs are first born, the prickles are mere knobs, quite soft and flexible. As the puppies grow older the spines harden and become sharp at the point, and the little beasts acquire by degrees the power of roliing themselves into a ball like their parents. This power serves another purpose, however, besides that of mere defence: the spines and skin together form an elastic mass, so that when the animal wants to throw itself down a bank or precipice it rolls itself up into its sphere-like form and then trundles itself over the edge, blindfold and fearless, trusting to its elasticity to break the fall. When it reaches the bottom it uncoils itself quietly and waddles off about its business as if nothing had happened. The beady black eyes tell the truth as to their owner's intelligence : the hedgehog is an extremely clever and contriving creature.

It is interesting to note, too, that while in the mainland of the great continents-Europe, Asia, Africa-the hedgehogs and their like are all spiny, and possess the characteristic power of rolling themselves up into a perfect sphere, there are several half-developed hedgehog-like creatures, belated in various outlying islands, which are only rough sketches or imperfect foreshadowings of the fully-evolved type. Some of these, like the bulau 


\section{Animal and Vegetable Hedgehogs 149}

of Sumatra, have just a few stiff bristles scattered about here and there among the hairs of the back; others, more advanced, like the Madagascar tanrec, have strong and stiff spines, but cannot roll themselves up into a perfect sphere like the true hedgehogs. Intermediate species also occur which more and more closely approach our European pattern. It is probable that these interesting undeveloped creatures represent arrested ancestral forms of our own English type: but that while in the great continents, the stress of competition has resulted at last in producing our highly-evolved form, a few outlying groups in isolated lands (such as Haiti and Mauritius) have retained to this day the earlier features of certain primitive stages in the history and evolution of the hedgehog family. We have here, so to speak, all the "missing links" in the development of the group, preserved for our edification, like living fossils, in remote and scattered oceanic islands. Even so, while Paris, London, New York, and Calcutta are civilised cities, the Andaman Islander and the Melanesians of the Pacific represents in our midst the primeval savage.

But the sea has its hedgehogs no less than the land: and the close similarity between the habits and manners of the two is a beautiful exemplification of the general principle that similar conditions produce similar effects even in quite unrelated plants and animals. The most interesting sea hedgehog is a kind of globe-fish, and it is represented in its ordinary elongated swimming 
condition in No. 2. The porcupine-fish, as this odd creature is often called, has a smooth, scaleless skin, thickly covered at intervals with sharp and stout spines. When the fish is swimming freely about in search of food, the spines are retracted, exactly as in the hedgehog, and point inoffensively backward. But let an enemy come

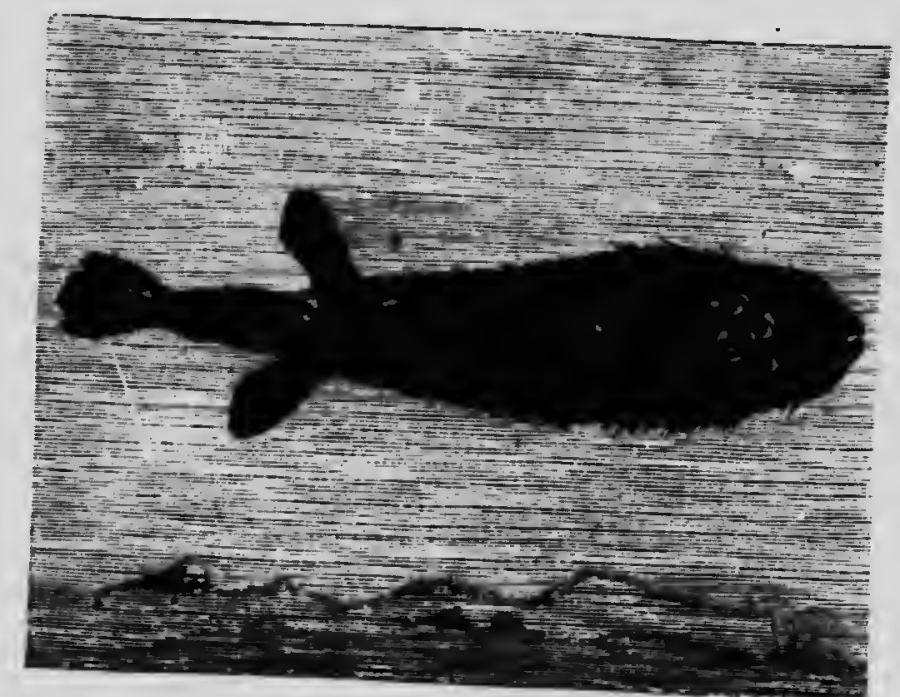

NO. 2.--A SEA HEDGEHOG, THE GLOHE-FISH, SWIMMING FREEI.Y.

in view, and, hi presto! what a change! The porcupine tish follows at once the tactics of his terrestrial analogue, and converts himself into a bristling ball of prickles, though by a somewhat different method. He rises to the surface and swallows in haste a quantity of air, which distends him instantly into a perfect balloon, as you see 


\section{Animal and Vegetable Hedgehogs $15 \mathrm{I}$}

in No. 3. The skin is thus stretched tight like a drum, and the sharp spines stand out straight in every direction, forming a radial ball, exactly as

- in the case of the hedgehog. This erect and threatening condition of the spines is still better exhibited in No. 4, which shows the porcupine-

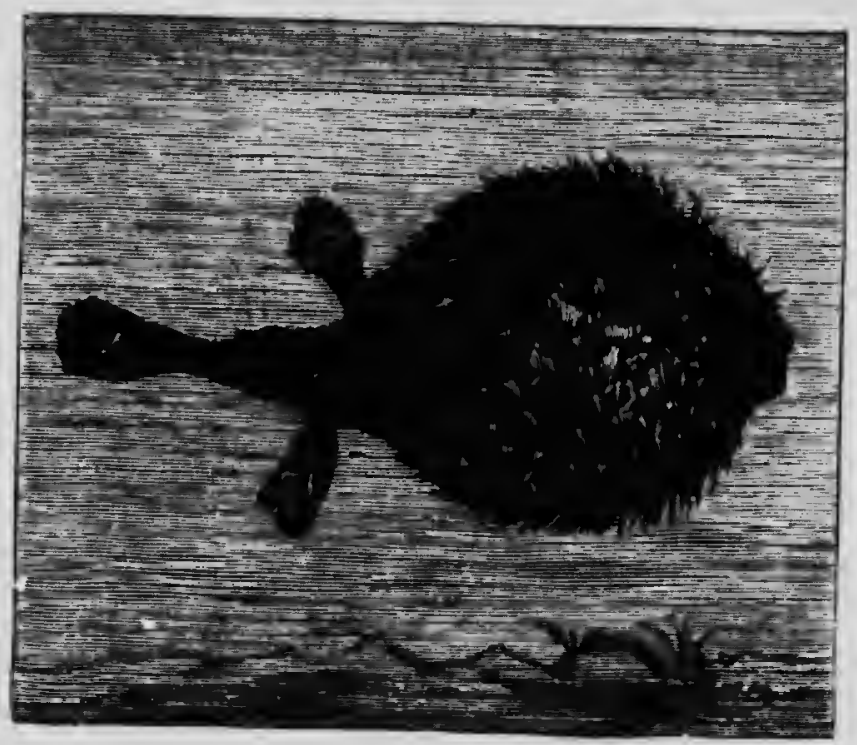

NO. 3-THE GLOBE-FISH, INFLATED, WHEN DANGER THREATENS.

fish a very tough morsel for any aggressive shark or dogfish which may be minded to attack it. Oddly enough, the distention has one most unexpected result. When thus inflated, as if he were a Dunlop tyre, the fish becomes top-heavy, and turns upside down, floating passive on the surface with his back downwards. He does not attempt 


\section{IN NaTURE'S WORKSHOP}

to swim, but lets wind and current carry him like a derelict vessel. Once the danger is past, however, the fish expels the air from its mouth with a gurgling noise, and resumes its usual free swim. ming attitude.

Few sea-Ivolves of any sort will venture to attack

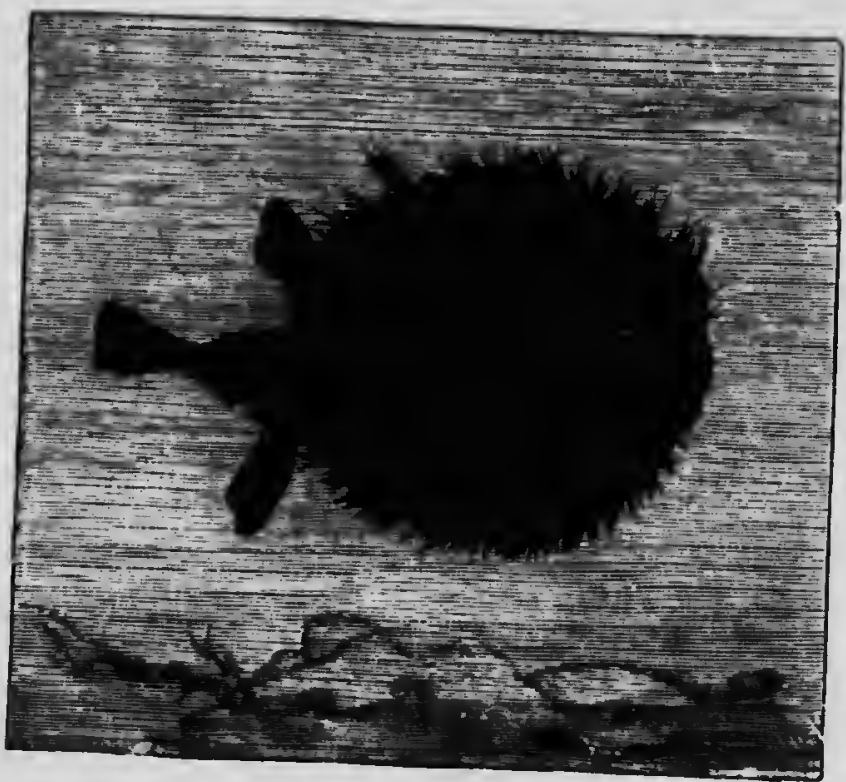

NO. 4. - "WHO'S AFRAID? LET 'EM ALL COME!"

a globe-fish in its distended state: those that do so have often reason to regret it. Darwin mentions that globe-fish have frequently been found floating alive and unhurt, within the stomach of a shark that has swallowed them, and even that one has been known to eat its way bodily through the devourer's side, so killing its would-be murderer. 
Animal and Vegetarle Hedgehogs 153

This feat is rendered possible by the very hard and sharp jaws or beak of the globe-fishes, which resemble the hedgehog in this particular toothat they crunch extremely hard food, such as coral, shell-fish, and lobster-like creatures, for which purpose their solid tooth-like jaws are admirably suited.

It is a pet theory of mine that whatever an animal does, some plant does also in all essentials. The hedgehog and porcupine with their vegetable imitators are good instances of the truth of this rough generalisation. For there are plant hedgehogs and plant porcupines as well as animal ones. The most remarkable and strictly analogous examples of these spiny plants are of course the cactuses, which may be regarded as in one sense the porcupines, and in another sense the camels, of the vegetable world. Cactuses grow wild only in very dry and poverty-stricken deserts, not absolutely waterless indeed, but given over for many months of the year to unbroken drought, and then drenched for a short time by the territorial rains of the tropical wet season. Under these circumstances, the cactuses have learnt to store water in their own tissues exactly as the camel does. They lay by, not for a rainy day, but for a dry one. Their stems have grown extremely thick and fleshy; the outer portion is covered with a hard and glassy skin, which resists evaporation; and when the occasional rains occur, the provident plant sucks up all the water it can get as fast as it can suck it, and lays it by for future use in the cells of the 
bark and of the spongy pith which forms its interior. Protected by their layer of impermeable skin and their immense bulk from the parching sun and dry winds of the Mexican desert, the wily cactuses are thus enabled to hold out for months against continuous droughts, exactly as the camel holds out through a long march by means of the water he has similarly stored in his capacious and spongy stomach. They are, in fact, living reservoirs, which act as tanks for their own water-
supply.

But the cactus has no green leaves; or, rather, lest some clever critic should come down upon me, after the clever critic's wont, for this too sweeping generalisation, I will say more guardedly, only a few half-developed and untypical cactuses have a few green leaves of the ordinary pattern : and these few species are not adapted for the most desert conditions. For clearly in very hot and dry countries thin green leaves would be worse than useless : they would be wilted up by the heat of the sun at once, and the plant would die for want of its accustomed mouths and stomachs. Hence almost all trees and shrubs which grow in very dry and hot regions have given up producing real leaves of any sort. In the Australian desert, it is true, the trees are covered with what look like leaves, but these are in reality thick flattened leafstalks : and even the leaf-stalks are all placed vertically, nos horizontally, on the stems-stand with their flat edge or expanded surface sideways, up and down, instead of being extended parallel to 
the soil, to catch the sunlight : they are thus struck by the oblique rays in the early morning and late evening, when the sun has little power, but not by the direct and scorching rays of midday, which would burn them up and wither them. It is this peculiarity of vertical foliage (or what looks like foliage) which gives rise to the well-known shadelessness of the dreary Australian gum-tree forests. In the dry region of America, on the other hand, most of the plants have given up the vain attempt to produce leaves altogether, or even to imitate leaves by flattened branches: they let the green stem do all the work of eating and assimilating usually performed by the true foliage. That is why most cactuses have nothing that ordinary people would regard as bark: the whole exposed surface of the plant has to be green, because it contains the chlorophyll or living digestive material which assimilates fresh food: the cactus eats with every fold of its skin or exterior layer. In reality, this exposed portion is all bark, from a botanical point of view : and so is the greater part of the internal waterstoring pith or spongy matter. But it is green bark, not brown: bark which has assumed the function of leaves under stress of circumstances.

Now, you will readily understand that, in a thirsty land, a plant so full of stored-up water as the various species of cactus must be very liable to attack from animals of all sizes. Any unarmed and unprotected kinds must thus from the very beginning of their family history have been greedily . devoured by the herbivores of the desert. The 


\section{6 \\ IN NATURE'S WORKSHOP \\ consequence is that only the best protected and most hedgehog-like species have survived to our day, especially in the driest portions of the desert}

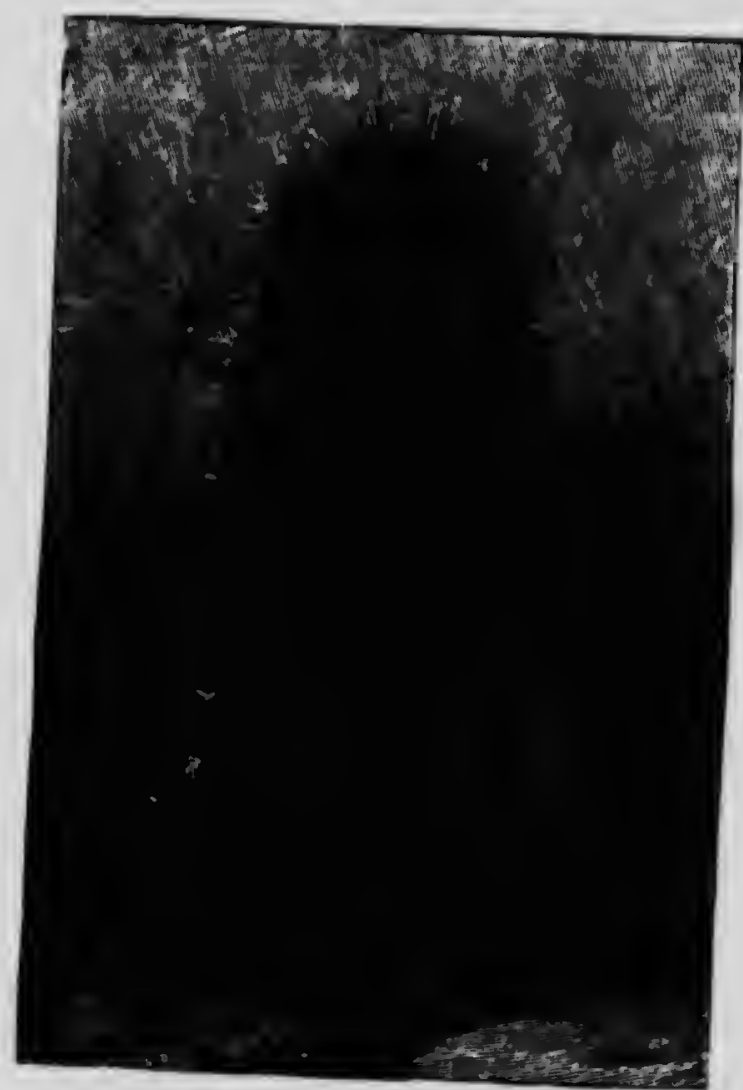

No. 5.-A VEgETABLF HEDGEHOG, ONF OF THト SPINY CACTUSES.

country. Nature is a great utiliser of odds and ends : she always finds some unexpected use for discarded organs. The cactuses, thus placed, and 
Animal. and Vegetable Hedgehogs 157

laving nothing more for their leaves to do in the ordinary way of business, invented a new function for them by turning them into spines to protect the precious store of internal water laid by in the spongy pith for the plant's own purposes. To deter thieves from breaking in and stealing this valuable deposit, they made their leaves ever shorter and stiffer, till at last they have assumed in many cases the form of regular rosettes of prickles, disposed in tufts over the whole surface of the plant that bears them. No. 5 shows us an excellent instance of these prickly and repellent desert types, a tall cactus which imitates in many ways a hedgehog, or still more closely a sea-urchin. No. 6 is an enlarged view of the top of the same plant, showing the thick coat of defensive spines, and the difficulty of attacking so bristling a treasure-house. Like a strong man armed, the cactus protects its vital water-supply with a serried row of weapons : it might almost be compased to a fort with an army mounting guard over its magazine, and fixed bayonets pointed in every direction. Observe how impossible it would prove to break the line anywhere; he would be a bold strategist who would venture to assault that perfectly defended position with its innumerable caltrops. The charge of the Lancers at Omdurman would be a mere trifle tu it.

Nevertheless, astute enemies do sometimes manage to get the better even of these experienced vegetable tacticians. The horses that roam halfwild over the arid plains of upland Mexico will often combine to kick down the fall pillar-like cac- 


\section{${ }^{1} 5^{8}$}

\section{IN NATURE'S WORKShOP}

tuses which grow upright in those regions, knocking them fiercely with their hoofs, and then eating the soft and juicy pith, with its ample store of contained water. They will also trample open the globular

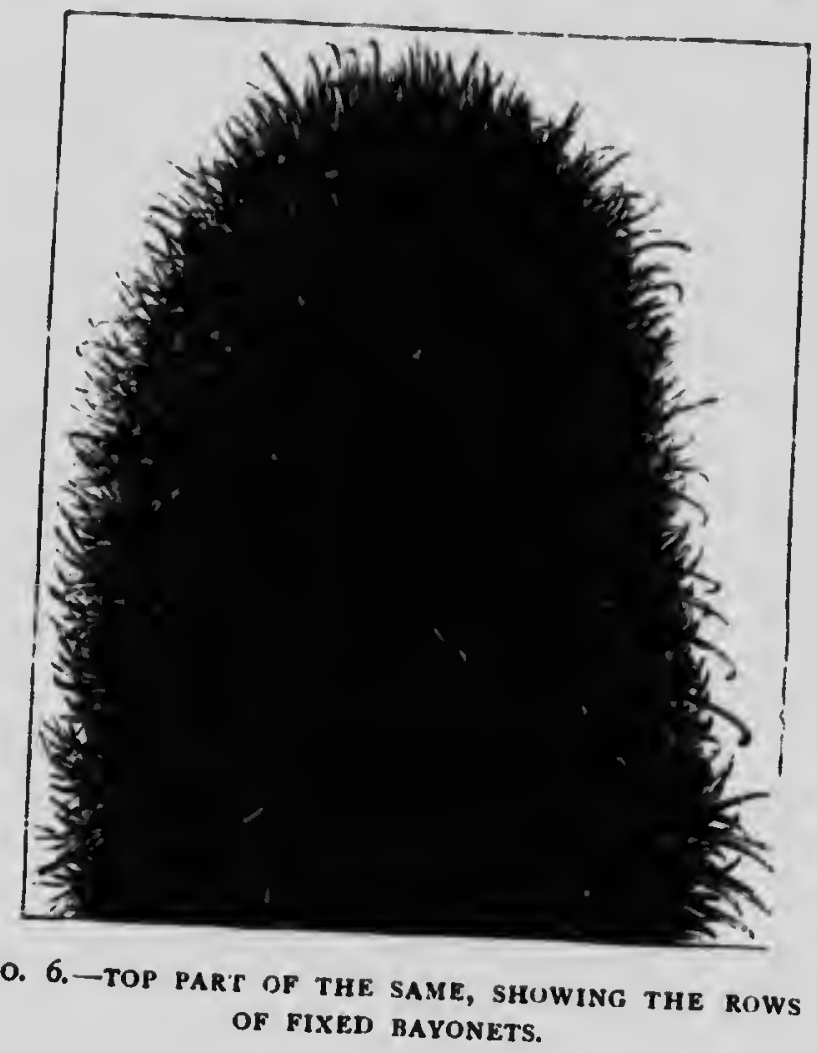

forms which abound in the same district, and feed greedily upon the succulent interior. But only extreme thirst and hunger would drive them to tackle so dangerous a plant, and we must remember that horses are not native to Mexico or to any part 


\section{Animal and Vegetable Hedgehogs 159}

of America: they were first introduced (in modern times at least) by the Spanish conquerors: therefore the cactuses could not have been originally developed with an eye to defence against such solid-hoofed enemies. As a rule a ca.... hedge is practically impervious to animals : hardiy any liviry beast will venture to face it. Even the wild horst semselves often receive dangernus wo mh whic king cactuses, which thus avenge $\|$ emselve" on th. invading army.

Various degrees o: hedgshing iness cisst, however, among the cactus group: Hhit at niore developed and less developed forms, according to the nature of the soil and the amount of rinfall or the character of the enemies to be expected locally. Some kinds, such as the leaf-like Phyllanthus, often grown in conservatories, are quite unarmed. Others, such as the well-known prickly pear-an American cactus now largely naturalised on the Riviera, in Italy, in Algeria, and in Syria-have comparatively few spines, though they are well beset with little groups of short sharp hairs, which break off at a touch and cause an immense amount of trouble in the hands when one rubs them. The fruit of the prickly pear is intended to be eaten : it relies upon aninals for the dispersion of the seeds: it has therefore relatively few spines, but it must nevertheless be handled with caution. Other forms of cactus are progressively shorter, stouter, and more spiny, until at last, in the most exposed spots, we arrive at that most perfect of vegetable hedgehogs, the globular melon cactus, many species of which are commonly culti- 
160

\section{IN NATURE'S WORKSHOP}

vated in pots in England, more for the oddity of their form than for the sake of the flowers. This quaint little creature is as round as the rolled-up hedgehog or the inflated globe-fish; and it is protected by a perfect array of thick and prickly spines. No. 7 shows one of these extremely dense forms, where the need for defence seems to have swallowed

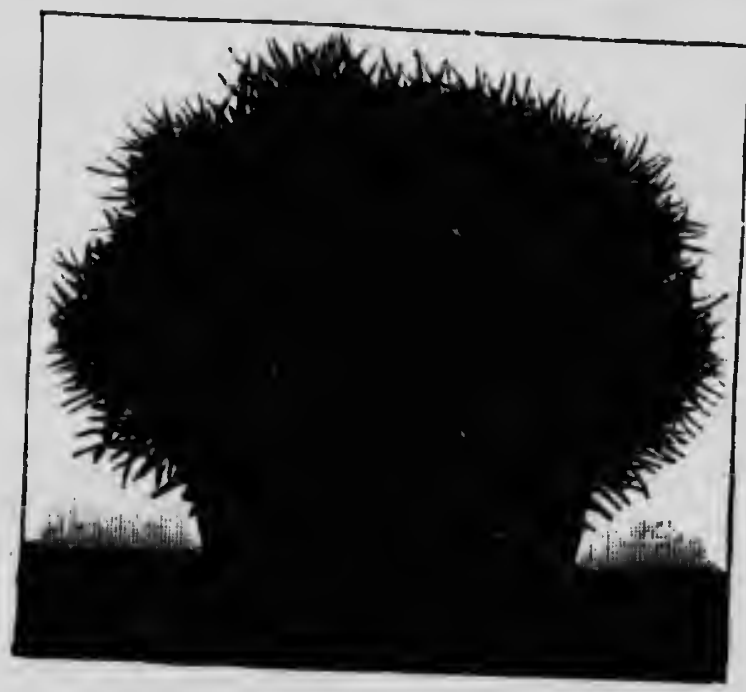

NO. 7.-A STILI. PRICKLIER CACTUS, ALL SPINES AND DEFENCES.

up the whole plant-like a military despotism, it has no time to think of anything but warlike preparations. Such types grow always in their native condition on very dry and open spots, where every living plant is eagerly devoured by the starving animals, unless it covers itself in this fashion with a regular arsenal of daggers and javelins.

It may have surprised you to be told that the spines of cactuses are in reality the last relics of the true leaves: I will return to that point a little later, and show by what gradual stages this curious transformation has been slowly effected. But for the 
Animal and Vegetable Hedgehogs 161 present I want rather to insist upon the point that desert conditions almost necessarily run to the production of excessive prickliness in all sorts and conditions of plants and animals. Where water is so scarce, food is scarce too: and where food is scarce hunger drives the few animals which can exist in the dry region to attack every living thing they come across, be it animal or vegetable. Hence, the

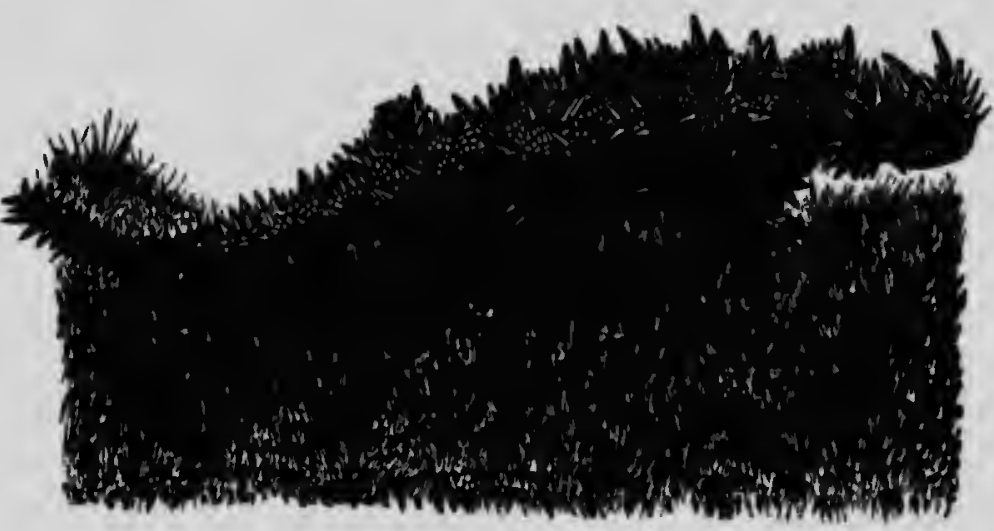

NO. 8.-A PRICKLY LIZARD, THE MOLOCH OR "TIIORNY DEVIL.."

smaller animals of deserts have need of protection just as much as the plants. Western and Southern Australia, as everybody knows, have a very dry climate, and they are provided accordingly with a most prickly and spiny fauma and flora. Their bush is sparse and extremely thorny. No. 8 shows you a very characteristic specimen of the animal forms which arise under such conditions. It is a lizard which frequents the driest and sandiest soils of that 
desert tract, and it is specially adapted for holding its own against the local lizard-eaters of the neighbourhood it inhabits. Science knows it by the scriptural title of Moloch-and, indeed, it is ugly enough and repulsive enough to be called any bad names; but the Western Australians, less polite in their speech than the Royal Society, describe it familiarly as the "thoray devil." It is one mass of spines, and its head and brain in particular are specially protected by a couple of prickly horns, bent almost like fish-hooks. The Moloch, in spite of its name, is a harmless crea ure : it does not attack: it uses its armour only, like the common thistle, for defence, not defiance. But, like most prickly beasts, it knows $i$ is practically safe from aggression, for it is as siow as the hedgehog in its movements, and basks openly on the sandhills, aware that few foes will venture to attack it.

A glance at No. 9, however, may bring into still stronger relief the point which I am labouring to show-the close analogy which always exists between plant and animal life under similar conditions. Here we have a bush which exactly represents the thorny Moloch in the vegetable world. The desert regions of South America, indeed, are full of prickly or armour-plated animals : and in the same desert regions we get a whole group of intensely spinous and armour-plated plants and shrubs, of which No. 9 is a capital example. This curious bush, known as Colletia, is now fairly common in hothouses in England, and is grown outdoors on the arid hills of the Riviera, where so many desert 
Animal and Vegetable Hedgehogs i63

shrubs from Mexico, Arabia, Australia, and Peru find a congenial home. It is really the prickliest thing I know, for its branches are very stiff and its points very sharp, and I havenever tried to handle one without wounding myself severely. The same conditions which make prickly animals make prickly plants: and Colletia is prickliness pushed to its utmost possible limit. It is true, the sharp ends are not so numerous as in many other instances, but they are as hard as steel, and as penetrating as a surgical instrument. Nobudy tries twice to fight a Colletia.

Our common English gorse, represented in No. 10, will help to show how foliage-leaves can be developed into mere defensive spines, as we saw with the cactuses.

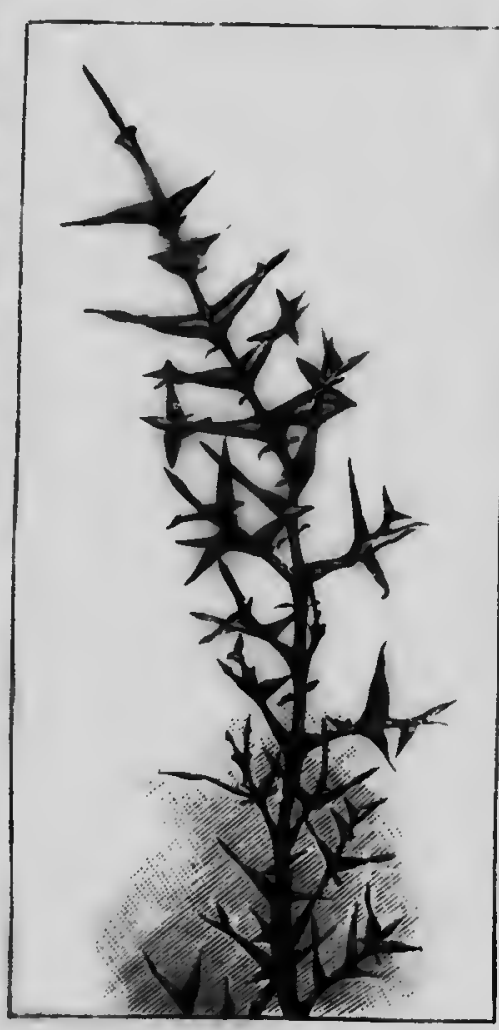

NO. 9.-A PLANT OF THE SAME: TYPE-THE COLLETIA. I have already explained in a previous volume that the young gorse seedling has trefoil leaves like a clover, and have pointed out how, as it grows older, the successive blades become sharper and 
I64

IN NATURE'S WORKSHOP

sharper, until at last they assume the shape of mere stiff prickles, scarcely to be distinguished from the pointed branches on whose sides they sprout. The illustration exhibits very well the intensely pro-

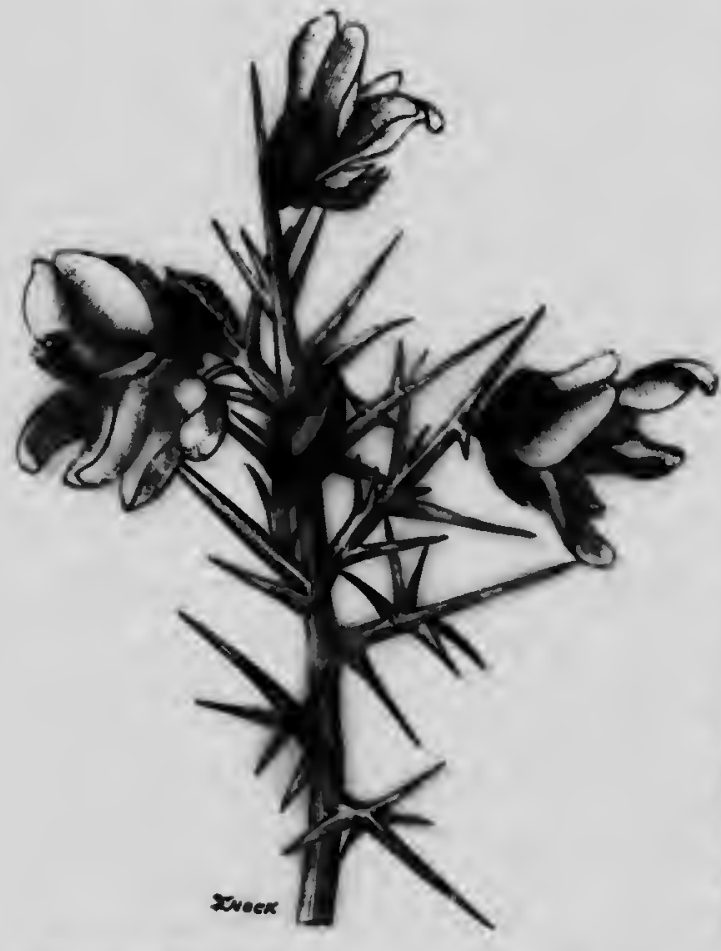

NO. IO. - BRANCH OF GORSE, WITH SPINES IEFENDING THE BUDS AND FLOWERS. tective nature of the spines, which are so arranged as to defend the flowers and buds from the attacks of enemies. Our common heather also tells one something the same tale: its leaves are s p iny, and would readily enough de. generate into prickles if need were: the cactuses have only carried thesame tendency a degree farther, and reduced the flat part of their leaves till nothing is left of them except the prickiy termination. Imagine a holly leaf or a thistle leaf with the fleshy portion suppressed, and you have an epitome of the probable history of the cactus-spine in the 


\section{Animal and Vegetable Hedgehogs 165}

course of its development from expanded foliage to defensive prick'e.

Indeed, in certain types, every stage occurs between the plants and animals which are quite undefended, through the plants and auimals which are defended in part only or on the most vulnerable points, down to the plants and animals which seem reduced externally, like the sea-urchin and the melon cactus, to a mere rugged mass of defensive javelins. Thus, among lizards, the iguanas have a sharp row of spines down the back only, the back being the part most exposed to attack : while others, like the horned lizards of Mexico and the southern United States, inhabiting the same dry region as the cactuses, are almost as closely covered with protective spines as the Australian Moloch. In the Arabian desert, once more, we get the thorny-tailed lizards, whose hinder portion is ringed round with prickles; and in other dry districts we find other protected kinds, progressively varying in the stage of their armour from the simplest to the most complex in every possible gradation. So among fish, No. I I represents a frequent type, answering to the iguana type among lizards, where a few strong spines on the crest of the back seem sufficient to deter most would-be assailants. Our own sticklebacks, as I have pointed out before, are smaller examples of the same principle. But the other kinds of fish have more and more scattered spines over the whole budy, till at last we arrive at highly protected species like the inflated globe-fish, which are veritable hedgehogs both in shape and in 
prickliness. You may observe that the best-armed kinds are almost always globular in form, at least in their defensive attitude, and are equally covered with prickles all over, because a sphere is, of course -as a soldier would say-the hardest "formation" to attack, while the equai distribution of the spines

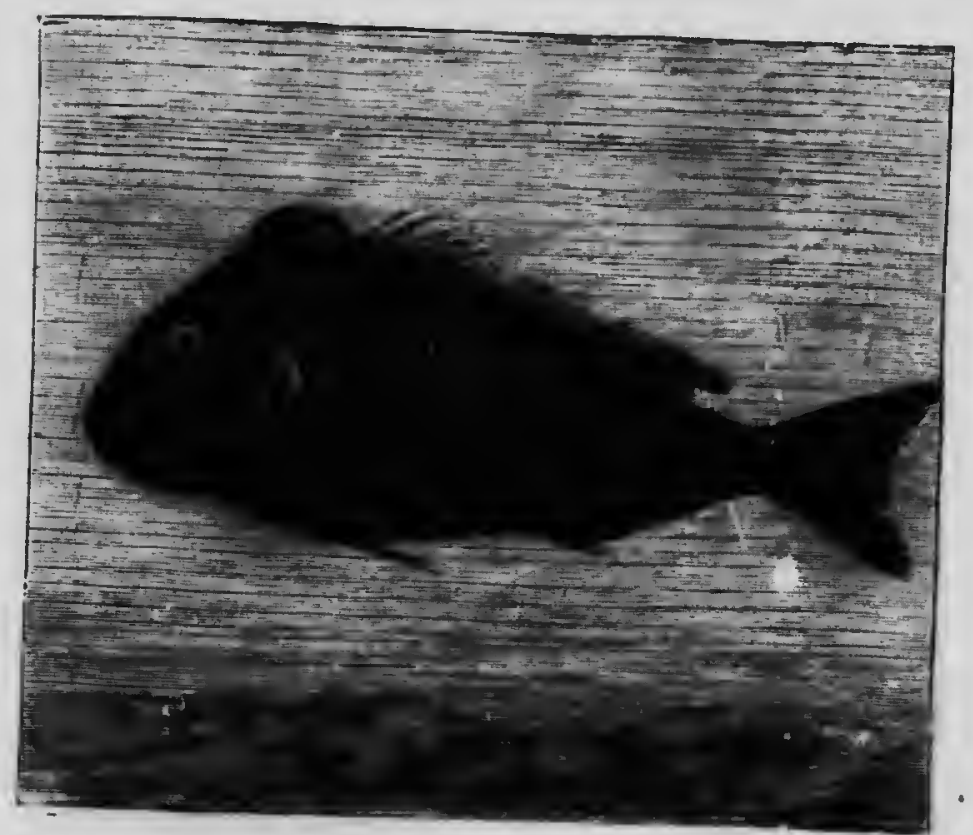

NO. II.-A FISH, DEFFNDED ON BACK ONLY.

leaves no loophole for approach to the most cunning assailant.

An exactly similar gradation from the unarmed through the partially armed to the highly defended can easily be traced in many groups of plants. Take, for instance, the thistles. Here, there are one 


\section{Animal and Vegetahle Hedgehogs 167}

or two species which, though they look much like other thistles both in foliage and flower, have really no actual prickles at all ; the ends and angles of the leaves, while shaped as in the armed sorts, are quite soft and yielding. Then there are more advanced types which have hard prickly points to every lobe of the leaf, but still can be grasped by the smooth and unarmed stein; these kinds live mostly in rather exposed spots, but not in those where com: petition is fiercest and grazing, animals most numerous. Last of all, we get species like the one represented in No. I2, which have the leaves prolonged down the stem by means of prickly

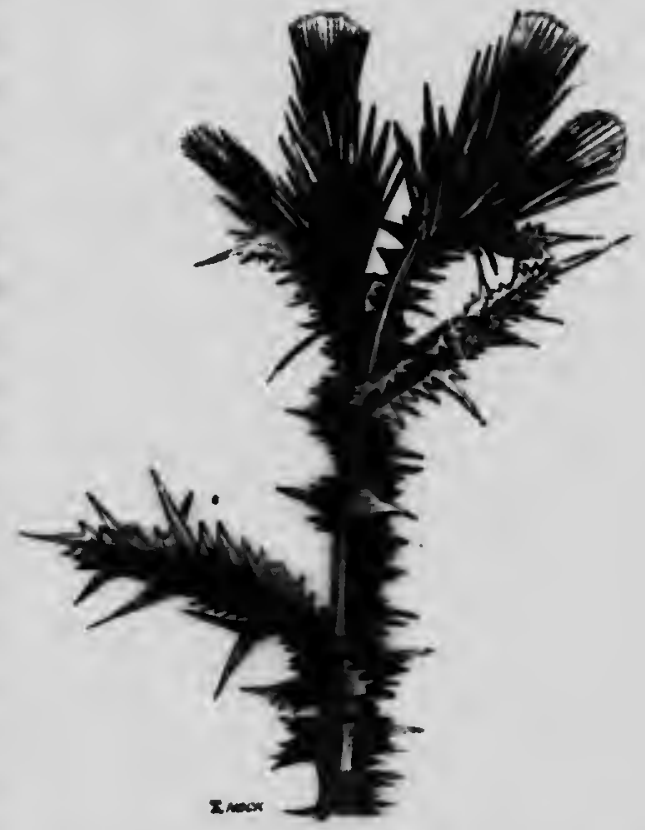

NI. 12.-A SHINY THISTLF, WITH PRICKLES RUNNING DOWN THE STEM. wings, so that every portion of the plant is absolutely protected. Such sorts are developed on open commons and in boggy clay soils where pasture is abundant. In the nettle tribe, the same tactics are carried still further, for there each hair or prickle has a poison-bag at its base-a sort of snake's fang 
in miniature-and positively stings the invader like a bee or a mosquito. This is an extreme instance of that likeness of plan which everywhere pervades plant and animal life. If we knew stings only in hornets and wasps, we should laugh at the notion that a weed could resent and resist intrusion by injecting poison into its assailant; yet nettles are such common and familiar objects in a country walk, and have so often forced themselves upon our unwilling attention, that we have almost for-

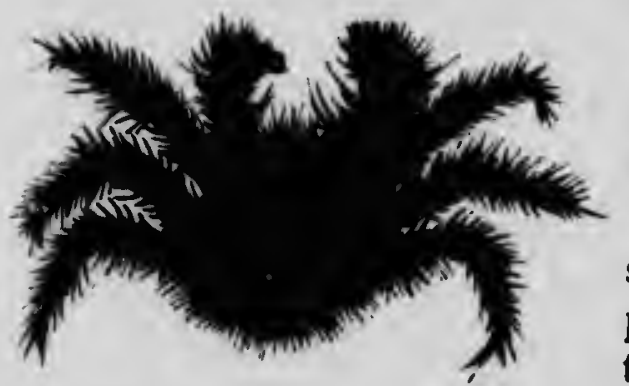

NO. 13. -THE PRICKLY CRAB. gotten how to be astonished at the marvel of their be. haviour.

The sea is, if possible, even fuller of prickly creatures than the land. Against our hawthorn bushes, our brambles, our porcupines, and our "thorny devils," it sets an immense array of spine-bearing animals of every conceivable type and pattern. They occur in every group. The common lobster belongs merely to the armour-plated section, like the tortoises and armadillos: but there is a well-known prickly lobster which also comes frequently into the London market, and which has its back all studded with defensive spines of the most deadly character. Similarly, most crabs have smooth shells; but there are certain prickly devilcrabs (No. 13) which consist of one serried mass of 


\section{animal and Vegetable Hedgehogs 169}

dense spikes, and which probably never get attacked at all by any other animal. The edible prawn is not prickly all over like these crabs, but he has a sawlike beak, which must suffice to ward off most assaults of his adversaries. A great many mollusks have shells with spines and other sharp projections, and these obviously serve to defend them from their enemies. But it is among the smaller and lower

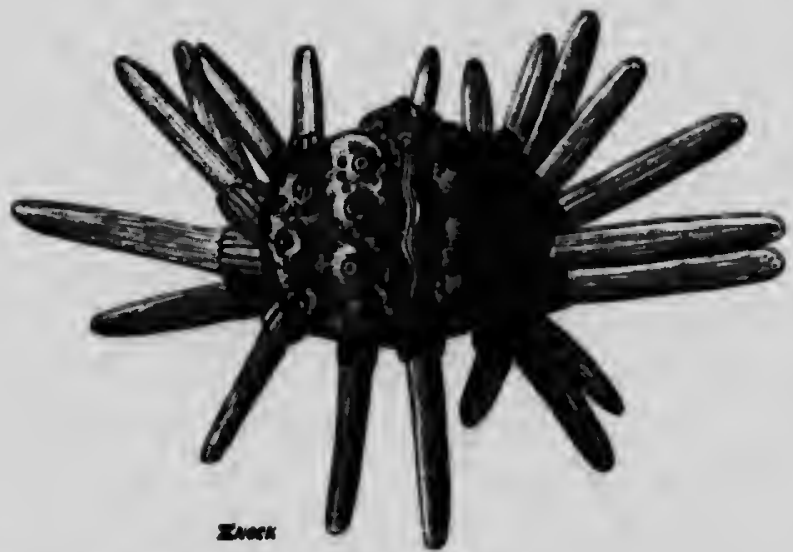

NU. I4- - A SEA-URCHIN, WITH SOME OF THE SPINES REMOVED TO SHOW THE SHELL.

sea-beasties that one finds the greatest number of prickly forms. The starfish are frequently spiny on their exposed upper surface, and the very name "sea-urchin" is equivalent to sea-hedgehog, urchin being an old-English corruption of the French herisson. Most of the sea-urchins are intensely prickly : the curious one depicted in No. 14, where it is partly deprived of its spines, to show the shell, is not so much prickly as difficult to tackle for want 
of a point of approach : it resembles rather a blunt arrangement of chevaux de frise than a circle of fixed bayonets. Roughly speaking, one may say that an immense majority of the lower creatures in the sea are more or less protected in one way or another. Either, like the urchins, they have spines and spikes: or, if they are soft, like the jelly-fish, then they frequently sting : or, if they do not possess either prickles or a stinging fluid, then they are nasty to the taste, and advertise themselves as such by means of brilliant colours, as is the case with a great many sea-slugs. , A walk through the galleries of the Natural History.Museum at South Kensington will show you at once how extremely frequent are these prickly animals, especially in the sea. And here I will just add parenthetically that it is very little use strolling listlessly through such collections, as most people do, with a casual glance right and left at the various cases: if you want a visit to a museum to do you any good, you must select some such line of study for an afternoon as this, and go through the corridors looking out carefully for the different plants and animals which exemplify (say) this defensive prickly habit in every direction.

Even insects are often prickly, though we are a little apt to overlook the real prickliness of these smaller types, because it often does not look to our clumsy nig eyes much more than mere hairiness, or even downiness. What is to us men a soft fur on the stem of a plant will often prove to an ant an impassable jungle like a tropical thicket : and what looks to our sight a woolly caterpillar, may seem to 
ANimal and Vkgetahle Hedgehogs 171

a bird a harsh spine-covered creature. Sometimes, however, the spines on insects are spines even to our human eyes: as is the case with the welldefended prickly beetle illustrated in No. 15, where the creature is seen appropriately walking about on the leaf of 'a favou.ite thistle, just as the hedgehogs skulk among gorse or blackthorn, and as the prickly lizards dwell habitually in regions of prickly shrubs, prickly weeds, and pricklybushes. Many other beetles have spiny horns or projections which serve them in good stead as protective devices: a well-known case is that of our large and handsome English stag-beetle. Most of these armed creatures are as little likely to be molested by importu-

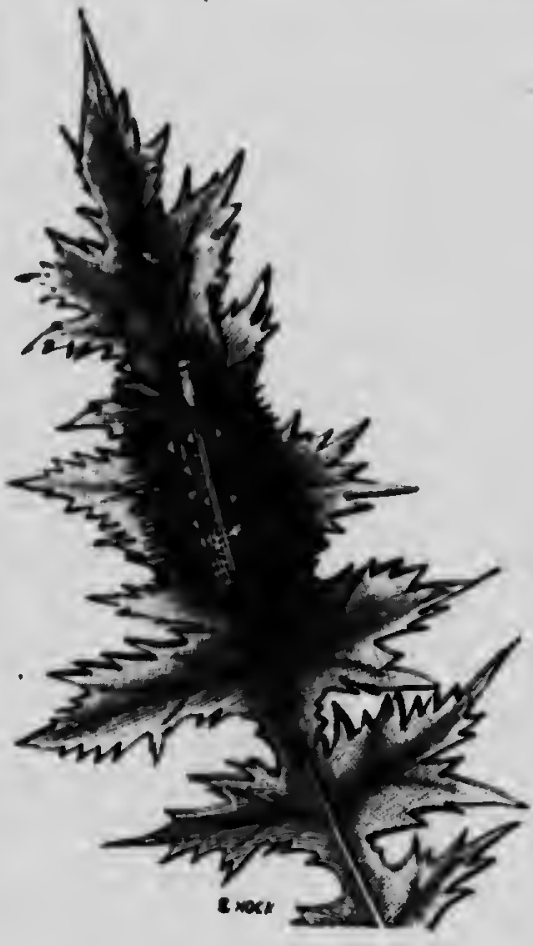

NO. 15.-A PRICKLY BEETLE. nate enemies in their own small world as the hedgehog, the porcupine, and the sword-fish are likely to be molested in large circles. Of course it is impossible here to do more than quote a few examples out of the thousands that exist: but there are wild regions 


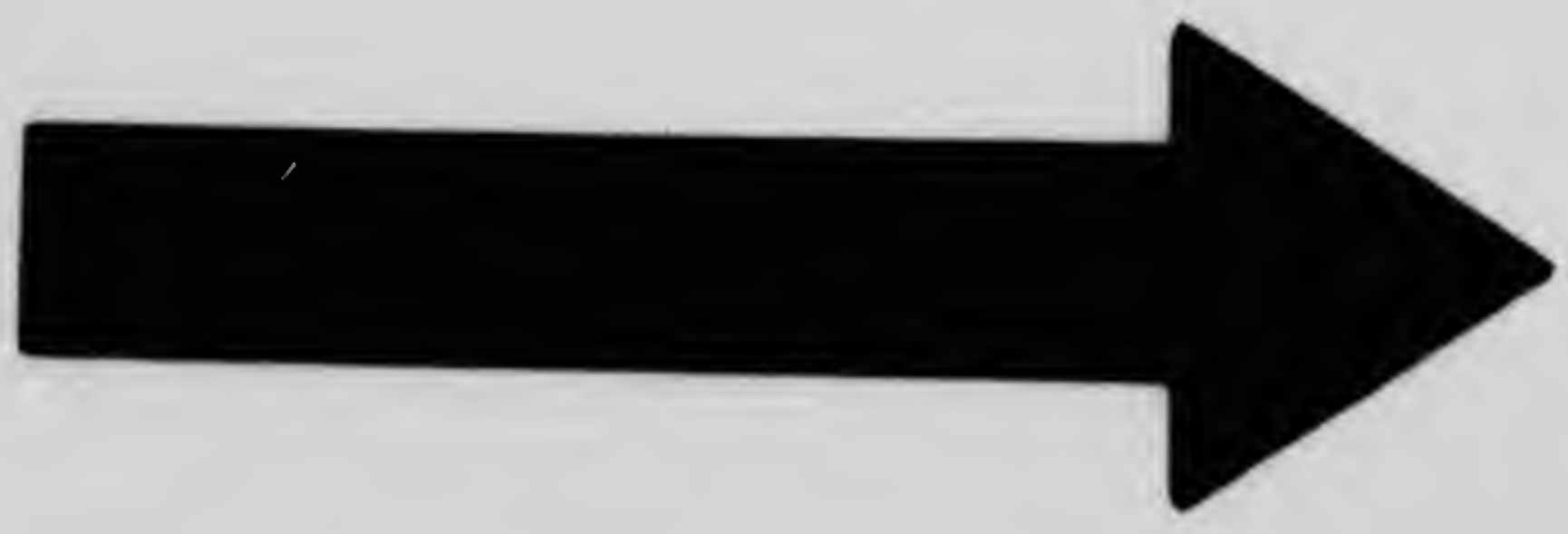




\section{MICROCOPY RESOLUTION TEST CHABt}

(ANSI and ISO TEST CHART No. 2)
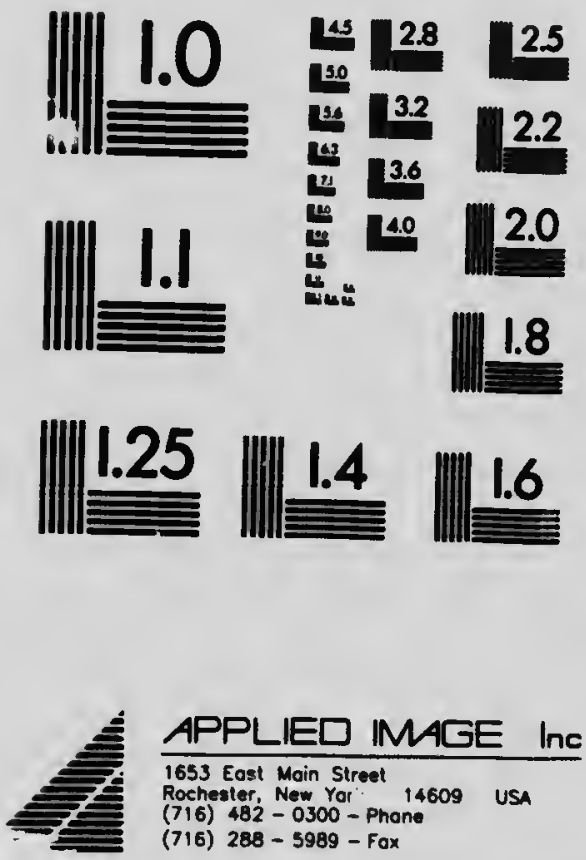
of the world where almost every plant and a vast number of the animals are thus covered with sharp thorns, or spines, or bristles. This is especially true of the Mediterranean region, as every one knows who has wandered on the dry hills behind Nice and Cannes, or botanised the prickly bushes in the

North African

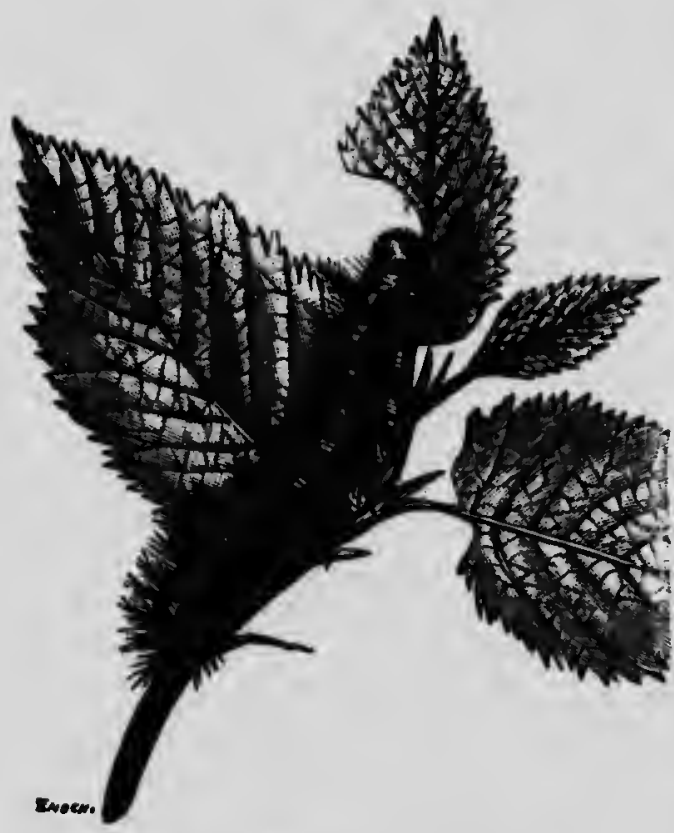

NO. 16.-A PRICKLY CATERPILLAR. mountains, or hunted insects among the dry and thorny acacia scrub of Syria and Egypt.

No. 16 introduces us to one of the many caterpillars which are protected by such spines or bristles as seem to us men scarcely more than hairs. It is the wellknown larva of the tortoise-shell butterf $\because$. At first sight, you could hardly suppose that these hairs could be classed among the spikes and prickles we have hitherto been considering. But just imagine yourself a bird, and try to think of yourself as swallowing one of these hairy insects. It must be 
pretty much the same thing as if you or I were to try swallowing a clothes-brush. As a matter of fact, indeed, protected caterpillars like these are seldom or never eaten by any of the small birds which frequent our hedgerows; though they have other enemies which manage to tackle them somehow. The cuckoo, for example, is an insatiable caterpillar-eater, and, strange to say, he delights, most of all, in the hairy forms. He seems to have a throat specially constructed for bolting thein, while the hair or bristles form at last a perfect coat of felt in the bird's stomach. That is characteristic of the check and counter-check of nature : every move on one side is met and defeated by an opposite move on the other. Nevertheless, it is quite clear that most hairy caterpillars are amply protected from the majority of their enemies, for they show themselves openly, like hedgehogs and porcupines, and do not attempt concealment like the edible sorts; though when attacked, they often roll themselves up into a ball, after the fashion of so many other animals in this protected group, and turn a uniform set of stiff bristles towards the attacking party.

It cannot be by accident, I think, that the globular form is assumed in such different cases both by thorny plants and by prickly animals. The various creatures must have learnt by ancestral experience that this spherical arrangement of the spines or hairs is the best mode for defence: and while some of them, like the melon cactus and the sea-urchin, assume it permanently, others, 
like the hedgehog, the globe-fish, and the woollybear caterpillar, assume it only when special danger threatens. It is curious to note that something similar happens with armadillos and woodlice, as well as with many marine animals of the armour-plated kind. Analogies like this run all through nature: they recur again and again in the most unlike r.lasses. What succeeds in one place will succeed in another, where conditions are similar: whatever device is hit upon by one plant or animal is almost certain to be independently hit upon in like circumstances by some other elsewhere. We are all of us a great deal less original than we suppose: and as for us men, it almost invariably happens that our latest invention has been anticipated ages ago by a grub or a sea-anemone. When we prepare to receive cavalry on a thick wall of bayonets at different angles, what are we doing after all save imitating a device long since inaugurated by the hedgehog, the cactus, and the hairy caterpillars? Our hollow square is but an echo of the sea-urchin's shell; our armoured ships, with their destructive rams, are strikingly like the lobster with his pointed forehead. If you look abroad in nature for such hints and anticipations of human progress, you will find them on all sides-especially as regards the arts and stratagems of war. It is only in the highest industries of peace and the fine arts of beauty that we have really got so very much ahead of our dumb relations. For desert warfare, in particular, was there ever a finer strategist than the humble 


\section{Animal and Vegetable Hedgehogs 175} melon cactus? Cornmissariat is always the great problem in the desert; wells are the crux : he has solved that problem and avoided that crux in a way that would seem to deserve a peerage. 


\section{VII}

\section{THE DAY OF THE CANKER-WORM}

T $T$ was Attila's hoast, they say-I never met him personally - that where his horse's foot had once trodden, grass never grew again. Chief of the countless hordes of Huns and other barbarians scattered among the northern mosses of Europe and Asia, he swept, the Scourge of God, across the civilised but decrepit Roman empire, and left behind him one broad path of destruction in ruined towns and desolated homesteads. Centuries later, another Mongol, Timur, came forth from the same savage heart of Asia, and built his pyramid of skulls among the lonely steppes to testify to the countless thousands of human lives he had recklessly sacrificed. But these historical plagues of conquering kings, though terrible indeed in their kind, are as nothing in devastating poiver when compared with the destructive insect armies which from time to time burst over and obliterate whole wide areas of culture. The hosts of locusts which eat their way across the face of a continent might make Attila's boast with greater truth than the ferocious Hun himself could make it : the desolation which follows one of these terrible floods of living things is appalling to behold. And then, does not the very petti- 
ness of the enemy render him harder to engage? Artillery is useless against myriads upon myriads of tiny foes; even railway trains have been stopped in their course in America by hordes of insects. The smaller and more numerous the adversary, the less the chance of engaging him with honour: you kill a million; and straightway ten millions take their place. France has lost more by the phylloxera which devours her vines than by the indemnity she paid to Germany for the war of 1870 : and the worst of it is, the Uhlan has gone, but the phylloxera still remains encamped and intrenched in all her vineyards. That tiny fly is an enemy with which treaties and capitulations are impossible: no cession of fortresses will satisfy its greed; no promises of money down or of territory ceded will induce it to forego its conquered provinces.

I propose in this chapter to trace the life-history of one or two among these famous armies of conquering insects, the Assyrian hosts or Napoleonic hordes of their kind, creatures which are produced in vast quantities at once, and which suddenly appear in devastating numbers over whole areas of country. And I do not think we can do better for a beginning than by taking the case of that too familiar American pest, the so-called seventeen-year locust. American, I say, because in this, as in most other matters, America still "whips creation." When the United States go in for anything, they go in for it as a rule on the huge scale: their vast areas of forest and prairie and wheatfield allow the development of gregarious life in a way unknown to 
our little peninsular and mountain-severed Europe. Here we have meadow and pasture and copse and heath dividing the soil with corn or turnips: in America, wheat occupies whole square miles in a line, and so affords an easy prey to every aggressive insect. Hence it happens that such pests in the States assume the proportions of veritable armies, and that skilled entomologists have to be employed by government like policemen or soldiers in order, if possible, to check the assaults of the foe by opposing to each its own appropriate natural and hereditary antagonist.

You will hardly be surprised to hear at the outset that the seventeen-year locust is not a locust at all. "Things are not what they seem," the poet tells us; and most plants and animals are so strangely misnamed by popular natural history, that the fact of a creature being called by one name almost suffices to make one conclude it must deserve another. Locusts in Africa are very destructive beasts: a cicada in America is equally destructive : that casual resemblance of habit and practical result was enough to make the American farmer call his own local pe-t by the name of locust. But if you look at the portrait of the female cicada, as shown in No. 15, you will see at a glance that she does not present the sligintest resemblance to the true locusts, but that on the contrary, she is almost identical with the quaint little chirpers which keep up such a ceaseless and emulous concert in the fields and woods of Southern Europe in piping summer-time. Wherever 


\section{THF: DaY OF THE CANKER-WORM}

vines grow, there you will find the south European cicada busily performing. Its continuous song is faintly pleasing to most people, especially if heard at a little distance: but it becomes disagreeable at last, from its constancy and monotony, and if heard very near it is harsh and grating.

A word or two at the outset about cicadas in general, viewed as a family, may help to put you more at home with the group as a whole: after which, we may proceed to inquire into the domestic concerns of the seventeen-year cicada herself in particular. Cicadas in the lump are large and stoutbodied insects, of the beaked class : they are very musical in their tastes, and have wings which are arranged slantwise, like the roof of a house. Their food is strictly vegetarian. Like all their kind, they are specially adapted for living by suction, draining the juices of the plants on which they fasten. For this purpose they are provided with an elaborate and highly-developed beak, intended for piercing the tissues of the food-plant. The females have also a stout and horny egg-layer or ovipositor, extremely complex in its mechanism, as I shall show hereafter; and this egg-layer is equally designed for making incisions in the tissues of plants, and laying the eggs where the young grubs, in their earliest stage, will be safest from attack and surest of rich and nutritious provender. Cicadas have always two large and very prominent eyes, set sideways at the edge of the head: but in addition to this pair, many kinds have also three secondary eyelets or ocelli, which are placed between the main eyes in the 
centre of the forehead: and these smaller eyes are frequently most brilliant in liue, with a gleam like a jewel's. Otherwise, the cicadas are not remarkably handsome or decorated insects; they reserve the whole of their asthetic taste for the musical faculty.

As a rule, indeed, you will find that birds and insects specialise their allurements in one or other of these two directions-song or colour; the two are seldom found together. Very brilliantly plumaged birds, like the peacock, the birds of paradise, the humming-birds, and the parrots, do not often possess beautiful voices : and, per contra, very sweet-voiced birds, like the lark, the nightingale, the thrush, and the linnet, are not usually remarkable for the hues of their feathers. It seems almost as though nature economised in the matter of display: where she attracts by song, she does not think it necessary to attract by colour; where plumage suffices to charm the eyes of delighted mates, she does not trouble to add music also. So pretty a girl, she says, can do without accomplishments: so accomplished a girl has no need for beauty. Now the cicadas are, almost without exception, musical. But their song is produced exclusively by the male insects, who are provided for the purpose with a curious resonant, drum-like instrument. It consists of a cavity with a stretched membrane, whose vibration, controlled by muscles, sets up the familiar chirping or stridulating noise so well known to all who have lived in Italy. In warm sunshine these insect vocalists keep up a continuous concert of sweet sounds, intended no doubt to 
attract the females. Resonators in the body increase the volume of the note, and make it carry further; we had one cicada in our house in Jamaica which sang so loud that we always knew it as the prima donna. We were wrong in the gender, I admit : we ought rather to have said the first tenor; for the females have no song: a fact much commented upon by the malicious Greek poet-doubtluss a married man, tied to a loquaciuus Athenian lady :-

"Happy the cicadas' lives,

Since they all have voiceless wives."

You can thus tell a male cicada from a female at once, because the large horny plate which covers the stridulating apparatus in the nobler sex is wanting or at least rudimentary in the ladies of the species.

But I am too long delaying the introduction of our particular subject, the seventeen-year cicada, who is really the hero of this present drama. The name is an odd one, but it is strictly true. The cicadas of this kind appear in each district once only in every seventeen years - "And that is once too many," said an aggrieved Kentucky farmer. The fact is, all cicadas remain for a long time underground in the grub condition before emerging in the upper air as perfect insects; and this particular sort takes no less than seventeen years to mature, though there is in certain States a thirteenyear variety or local species. No. I of my illustrations shows you a specimen with the wings on one side removed, so as to exhibit the chief offending 
organs-the mouth or heak (11) and the saw-like egg-layer (b). In the breeding seasion, the males appear for a short time only, sing, pair, and then die at once, it being probable, incleed, that they cimmot or do not eat in the adult or perfect condition. But the females make up for this liftle defect in their partners' economy by eating voraciously, and laying some four or tive liundred eggs apiece in the hucls or twigs of trees : after which they, too, proceed tı; die, having also fulfilled their place in

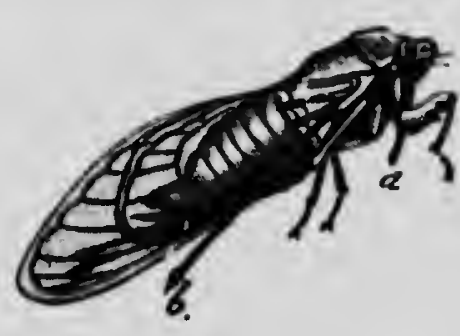

$\$$

NO. I. - TIIE SEVENTEEN-YEAK CICADA. nature. For the winged state in insects is msually little more tlan a device for mating and egg-lay. ing: it may be aptly compared to the flowering stinge in plants, since the flower exists only for the sake of being fertilised, and fades as soon as the seeds begin to set; its sole use is to attract the impregnating insects, as the sole use of the butterfly is to mate and lay eggs for future generations.

But the ovipositor or egg-layer, seen at $b$ in No. I, is a most remarkable organ, whose minute structure you can further observe in No. 2, where I have had it much enlarged for you. In $a$, this wonderful cutting instrument is seen from above, and in $b$, from beneath, the dotted lines being intended to indicate the up-and-down motion of the saw-like blades or cutters. These cutters are fitted together by grooves 
THF: DaY Or THF CankFir-wokM

into the fixed holder or atxis almost like at purz:le, so as to move up and down truly: and the cros:section in No. 3 enables you to appreciate the exquisite way in which the parts fit into once another, with that cestraordiniry accupacy only to be found in the works of nature. No. 4 , again, shows you how the incechanism acts as a whole. It exhibits a series of views of the twig of a tree operated upon by the seventeenyear cicada. At $a$, you
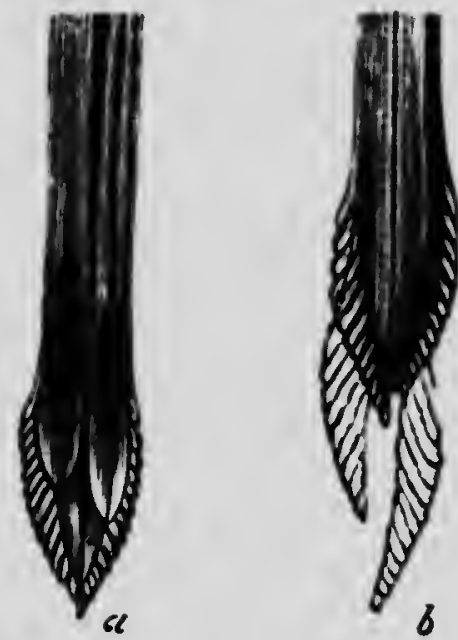
have a recent puncture drilled by the ovipositor.

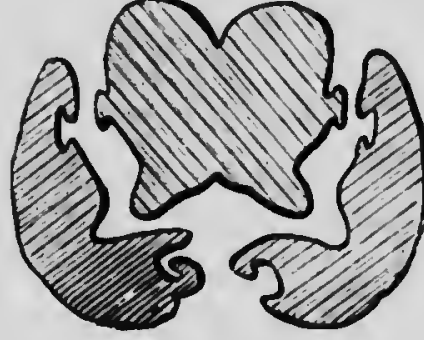

No. 3.-SECTION OF TIIE: SAW, SHOWING HOW THE PAKTS FIT TOGETILK LIKE A PUZZLL.

you will agree that a At $b$, the surface of the twig has been deftly removed, so is to show the arrangement of the eggs in the egg-basket thus cunningly excavatecl. At $c$, you have a sicle-view of the eggs lying in their basket; and at $a^{\prime}$, you have the cavity exposed after the eggss are removed, so is to let you see the sculpture left by the ovipositor. I think neater or more perfect nest 
could hardly be devised than this thus carved out of a living twig by the minute instruments at the disposal of a petty two-inch-long insect.
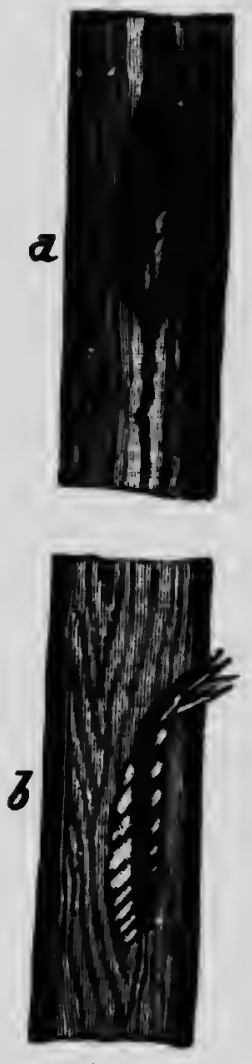

皮

NO. 4.-NESTS AND EGGS IN TWIGS of CHESTNUT.

The eggs soon hatch out in their snug little nest in the twig: but the larva do not con-

c tinue to live there permanently. In a very short time they drop to the ground, burrow their way into the soil by means of their strongtoothed thighs, and fasten on to the roots of trees and plants, where they $\alpha$ earn their livelihcod by perpetual suction. Caterpillars and other aboveground larvæ, exposed to stress of weather and with the perpetual terror of winter before their eyes, usually live and feed for one summer only: they turn into pupae during the course of that summer, or at best assume the chrysalis form in late 
The DaY of THE CaNkER-WORM

autumn, hibernating as well as they can in the dormant condition, and coming out as perfect insects with the succeeding springtide. But the cicada tribe pass their larval period for the most part underground, where they are tolerably protected from the inclemency of the weather, for frost never strikes deep; therefore they need be in no hurry to grow old apace : they can take their own time for arriving at maturity. And they do take it : they eat their way slowly and laboriously through life : one variety of the periodical cicada matures in seventeen years, the other in thirteen. Meanwhile, the larva lives by suction on roots and uriderground stems or tubers, doing much unobtrusive damage to vegetation in a quiet way, and eating what he can get with constant vigilance. Of course, he is often eaten in turn, in accordance with the usual law of nature : for myriads of the larva are devoured by birds, by frogs, and even by pigs, which grub them up with their snouts from the soil where they have buried themselves; but myriads more survive, and turn out in the end as fullywinged cicadas, to the no small disgust of the American agricultural interest.

No. 5 is a portrait of the larva, aged eighteen months. You will see at once that our undeveloped cicada is already a creature capable of doing a fair amount of serious damage to trees or crops ; and when you consider that he has still tifteen years to grow, you understand that he inspires a just fear in the bosom of the farmer who has most to deal with him. Admirably adapted both for sucking and nip- 
ping, as this picture shows, he can do as much harm as any insect of his size known to science, with the solitary exception, perhaps, of that famous winged fiend, the true African locust.

At the end of his long and tedious minority, the

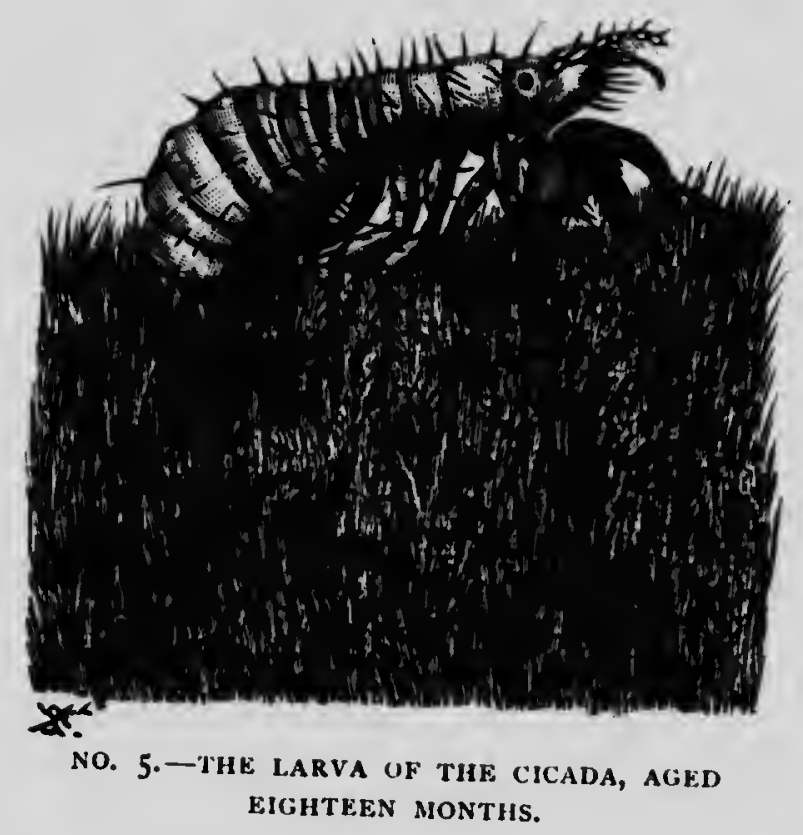

cicada larva begins at last to think of assuming the toga virilis of his race, and prepares to put on the robe of the pupa. But his pupa stage is not like that of the butterfly, an inert and mummy-like chrysalis existence: in common with the great group of beaked insects to which he belongs, the cicada only undergoes what is technically known as 
an "imperfect metamorphosis." The pupa in these cases does not become dormant : it is merely a sort of active hobbledehoy, which walks and behaves like the larva or the perfect insect: it represents an intermediate form between the grub and the winged cicada- an intermediate form quite as capable of taking care of itself as the perfect animal. For seventeen years vast hordes of larvac live unseen

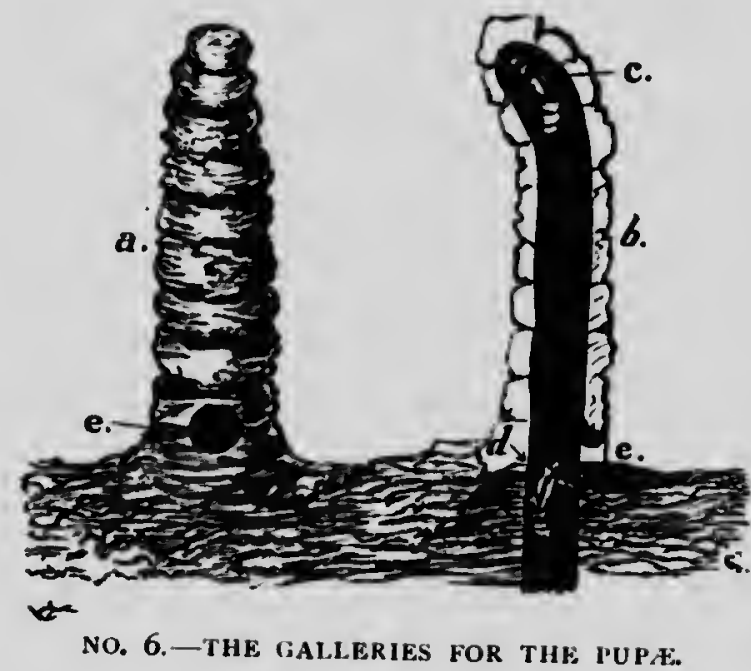

underground in the same district: at the end of that time, all with one accord begin to change into pupæ, and construct for themselves strange galleries of emergence, so that the soil in certain places seems honey-combed with their tunnels. Two of these galleries are seen in No. 6, one in front view, and the other laid open as a section. Here $e$ is the door or orifice of the gallery, and $c$ is a pupa wait- 
ing to undergo transformation; while $d$ is a brother insect just ready to metamorphose. Whole acres together are often covered and pierced with these strange tubes or shells, as thick as blades of grass in an English meadow.

No. 7 shows the next stage in the process of emergence. Here, the active pupa has walked up from the ground, and is just preparing to enter upon a new phase of life as a free winged insect,

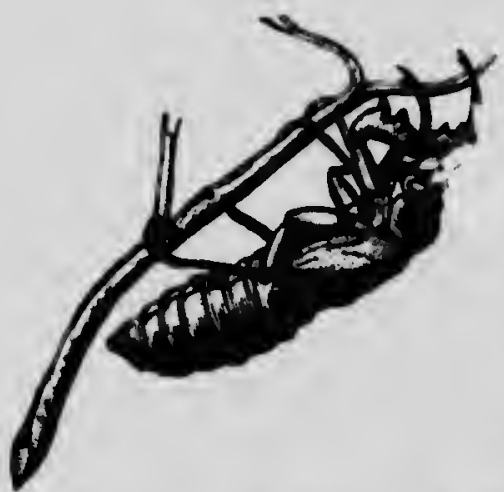

$2 x$

NO. 7.-THE PUPA COMES OUT. frequenting the open sunlight. It moves cautiously and slowly, a little clazzled and stunned, like a man brought up for many years in a mine, and then suddenly turned loose in the crowded and garish streets of some great city. No wonder the creatures feel like so many insect Kaspar Hausers, and move gingerly about on the branches which support them. The pupa crawls out upon a twig, and finds its skin has strangely hardened. After a while, it pauses, as in No. 8, and feels the hardened shell on its back gradually breaking. The winged cicada, which has formed itself within the pupa's skin, now begins to worm its way out with hereditary caution. In No. 9 you see it freeing itself from its mummy-case, a pale and ghost-like creature, as yet very timid and 
uncertain of the future. In No. 10, with one long pull, it has got its legs and wings free, but its tail still remains enclosed in the cast-off shell or pupal skin. The wings, you will observe, are at this stage very small, and quite inconspicuous: we shall see hereafter how they plim themselves out in the open air to the adult dimensions. In No. II, the emergence is almost complete, and the perfect insect only hangs by its tail to the

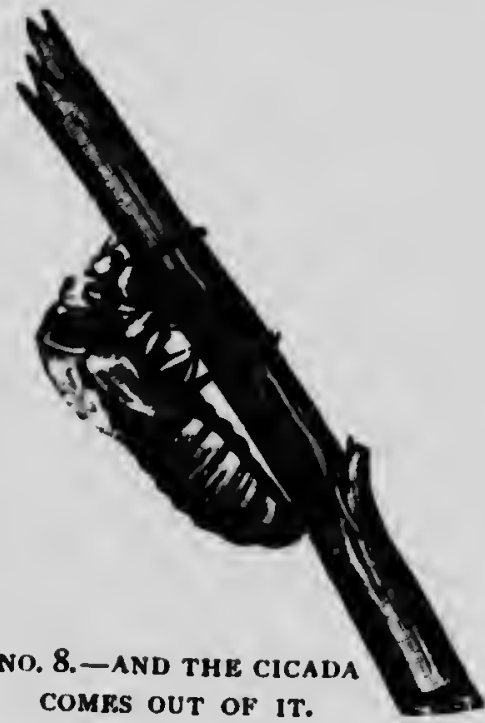
cast-off skin of its own pupa. The wings are here

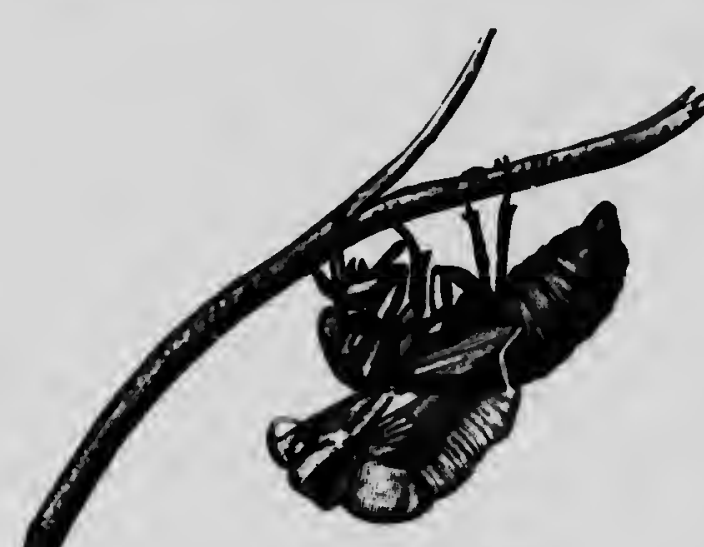

NO. 9.-BODY FREE : seen sideways, and have grown a little larger, but they are still rather thick or fleshy in texture, softly plastic, and wholly unfit for the act of flying.

The three next illustrations show the process of passing into the flying stage. In No. I 2, 
the newly-emerged cicada has cast itself quite free from the clogging garment of its pupal condition, and is balancing itself on a leaf preparatory to inflating and drying its wings. In No. 13, it has poised itself firnly, and is beginning to swell. In No. 14, the wings have been fully inflated, like a Dunlop tyre, and are now hardened and ready for action. In

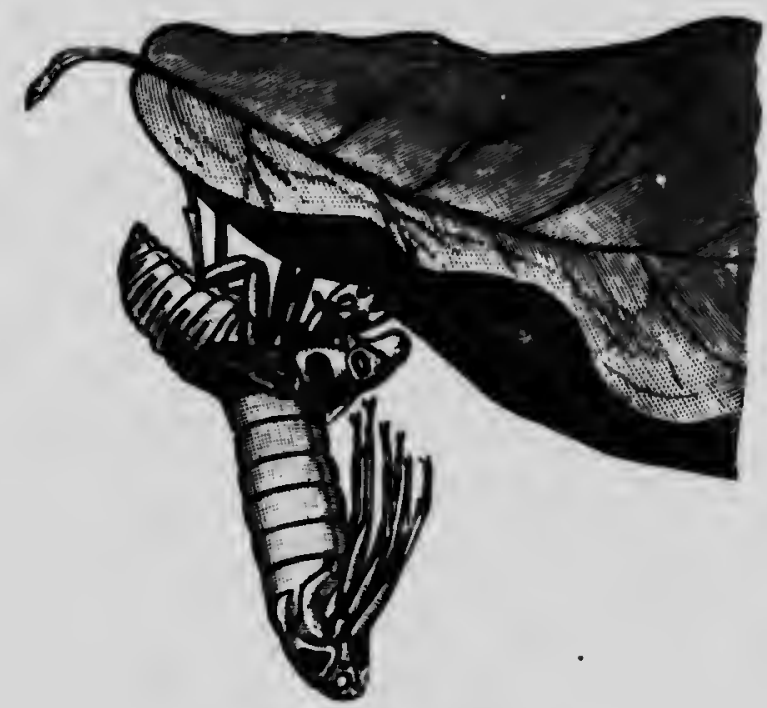

NO. IO.-WINGS AND LEGS ALL OUT!

this stage, the cicada assumes a beautiful glossy and satiny appearance, though it still looks a trifle pallid and ghost-like. The illustrations show you in each case only a single cicada: the American farmer has good ground for knowing that, like other misfortunes, they never come singly. When the moment for emergency arrives, the ground in an infested 
district seems simply to teem with masses of cicadas : mother earth brings them forth: they pour out in their millions, and devour everything on which they can lay their beaks with ruthless destructiveness. In a few days trees and shrubs are laid bare, crops are destroyed, and the year's labour is rendered vain by the victorious insects. The damage done by them as larva during their

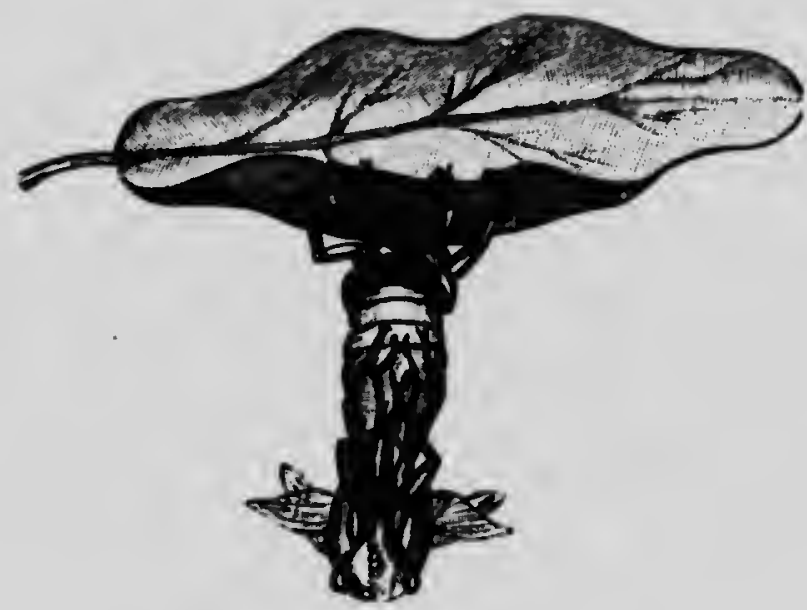

NO. 11.-HOLDING ON BY HER TAIL.

seventeen years of subterranean existence is as nothing to the damage done by the perfect insects during their short spell of adult activity. In Pennsylvania they have been known to bend and break down the limbs of trees by their weight: the forests ring with the shrill sound of their music.

For now comes the pairing season. Early in June, on every branch around, the male cicadas sit and beat their tiny drums as a summons to their 
lady-loves, in emulation with one another, like nightingales or skylarks. Sometimes you may hear two particularly loud ones singing or drumming in rivalry : as soon as one leaves off for a second, the other begins, like Virgil's swains, in alternate verses. Attracted by the sound, the clustering females alight

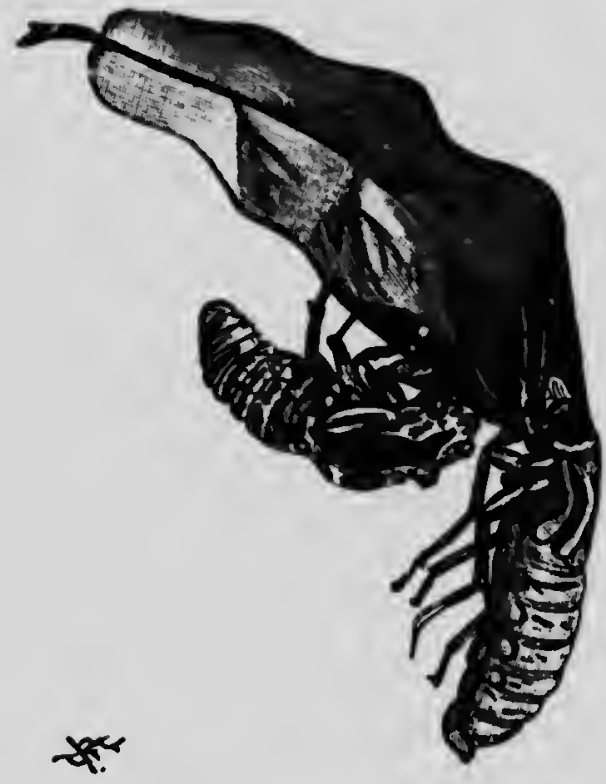

near the most favoured male, and soon select the partner that suits them. In the woods at cicada-time you may see hundreds and thousands of such little domestic dramas enacted on every side, the boughs being alive with many myriads of wiger performers, each surrounded by its own little admir-

NO. 12. - CICADA JUST EMERGED, WITH EMPTY PUPA-CASE. ing group of female listeners. All around, the branches of the neighbouring trees are covered with a drapery of rent and forsaken pupa-cases.

The next stage in the drama of cicada life consists in the disposition of the eggs. No. I5 shows us a female cicada, apparently lost in profound thought, and seated len thwise on a twig of chestnut. But 


\section{The DaY of the Canker-Worm}

she is not composing an epic : in reality, sle las pierced the tissues of the shoot with her auger-like egg-layer, and is now engaged in laying her eggss safe out of harm's way among the pigeon-holes of one of those neat little nests alreacly illustrated. It is for the sake of producing these eggs in sufficient numbers that the perfect insects-at least the females-have eaten so ravenously ever since they emerged from the pupal form: for they lay about a round five hundred apiece, and they have to devour material enough for this immense production in a week or so of rapid and greedy accumulation. You can't make eggs out of nothing, of course; and the more you have to lay, the more you must eat in order to lay them.

So far, we have dealt mainly with eating and

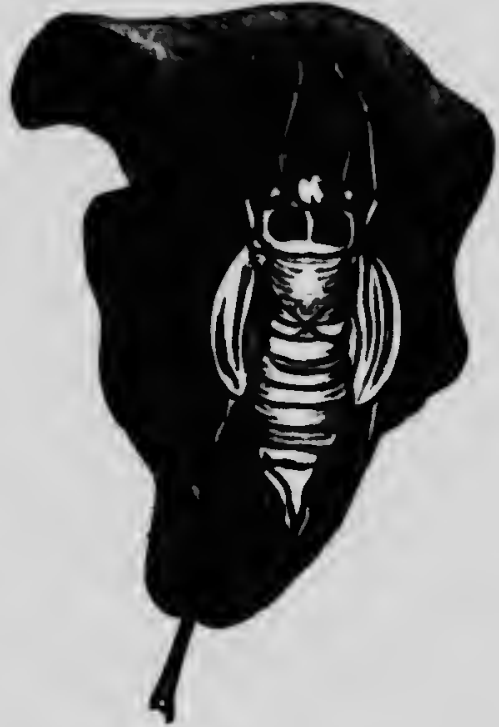

NO. 13-PI.IMMING IIER WINGS. drinking, marrying and giving in marriage, with a slight accompaniment of vocal and instrumental music. But the cicada's life is not always "all beer and skittles." No. I6 represents an untoward accident, to which our hero is commonly liable. A parasitic insect, by name Megastizus, smaller than the cicada, but stronger and heavier, seizes it 
bodily in his legs and carries it off to store his own nursery, exactly as evil spirits carry off wicked souls in old Italian pictures. Megastizus is a burrower, and No. 17 shows in a lurid light one of his underground tunnels, with his own ugly larva engaged in devouring the clead cicada. These burrows them-

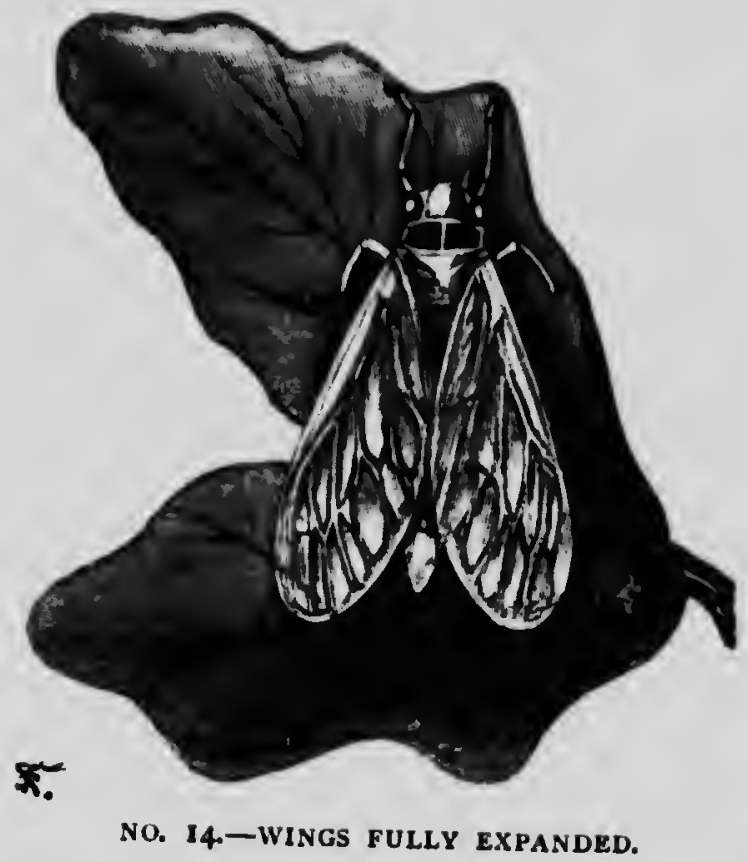

selves are singular examples of insect architecture, Ali Baba caves of tiny robbers : they are represented in ground plan in No. $18, a, a$ being in each case the door or entrance, and $b, b, b$ the little round chambers stored with cicadas in which the eggs are laid and the larva developed. The late Professor C. V. Riley, the official entomologist of the United 


\section{The Day of the Canker-Wokm}

States, made a special study of the seventeen-year cicada and this its natural enemy; and it is from materials kindly supplied by him to Mr. Enock that our artist has made the interesting sketches which accompany this article.

I have chosen the seventeen-year cicada as the first example of these destructive hordes of gregarious insects, partly because of the curious regularity of its reappearance in the infested districts, and partly because of its interesting musical tastes; but there are many other species equally destructive elsewhere, not the least formidable of which is the famous or infamous migra- $\star^{4}$ tory locust of

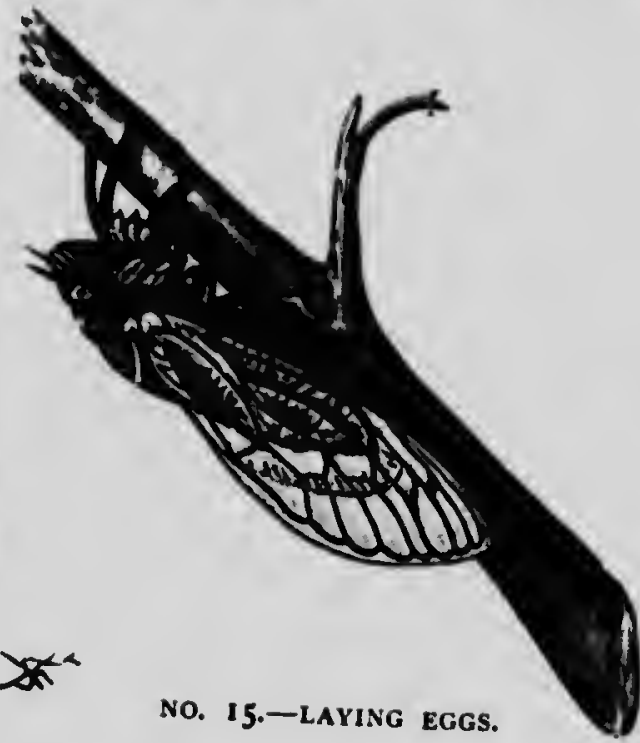
Oriental countries. The true locust is a large grasshopper-like creature, provided both with wings and with powerful jumping thighs : it is voracious in its appetite, and will devour almost anything, including at a pinch even its own species. The females are provided with strong and sharp egglaying implements, and you can often watch them boring a hole with these weapons in the desert soil, 


\section{IN NATURE's WoRkshop}

and depositing their numerous egges in the nest thus excilvated. I have seen them so by hindreds on the Algerian hillsides. From the first, the young locusts resemble their parents in everything exeept in the presence of wings ; they are most sociallele in their habits, and hop about in great swarms over the arid country at the edge of the desert. By-anclby, leaving the larval form hehind, they need their

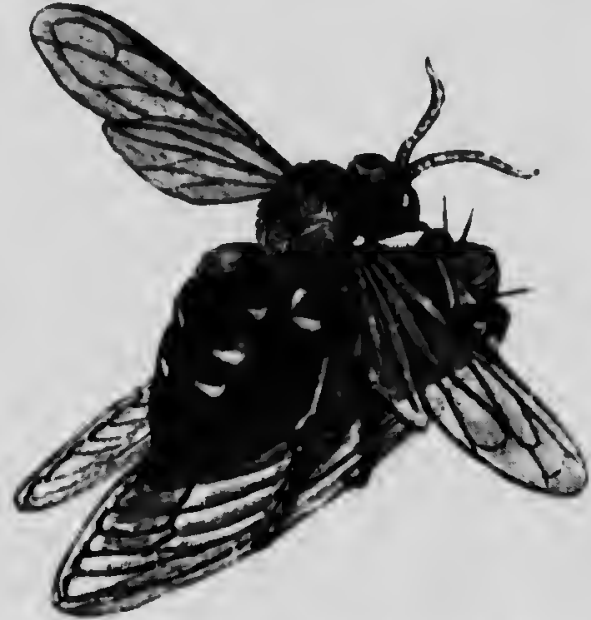

25
NO. 16. -CARRIFI) UFF HY AN ENEMY.

strong but delicate papery wings; and then begins a terrible and devastating migration. They have citten all there is to eat in their native belt, and must needs go elsewhere. Driven from home by humger, like the hordes of the north who attacked and overthrew the Roman Empire, the young locusts march forward in vast swarms, which sometimes extend over hundreds of miles of country together. If they succeed in finding a cultivated tract, they clear it in a few days of every living green thing : if they fail, they are almost equally to be dreaded in the end, for then they die by millions of starvation, and their rotting bodies, covering acres of land at once, fester in the sun and set up 


\section{ThE: DaY OF THE Canker-Wokm}

at last a pestilential malaria, which finally spreads as influenzar or fever to Europe and Americil. From all which it may reaclily he seen that the prophet Joel was not exaggereating when he de-

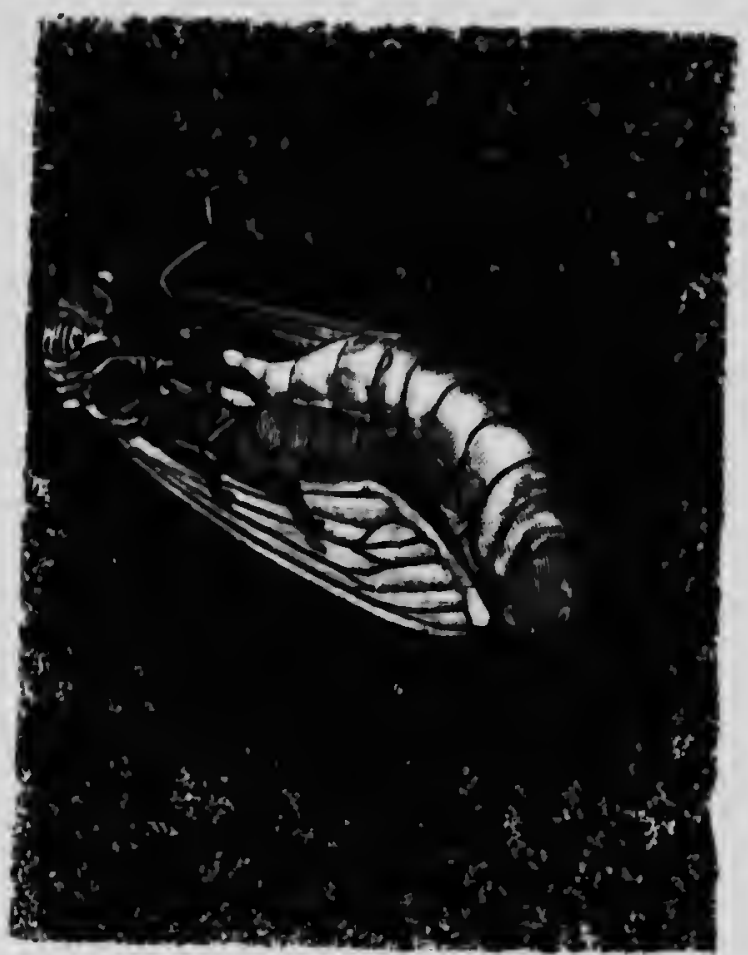

NO. 17. - THE FNEMY'; I.ARVA FEEIJNG ON DEAI CICAIS.

scribed the locusts as eating that which the palmerworm had left -" the laurd is as the garden of Eden before them, and hehind them a desolate wilderness."

But perhaps the method recently adopted by the 


\section{8}

\section{IN NATURE'S WORKSHOP}

British authorities for killing locusts in Cyprus affords the best commentary upon the numbers and destructiveness of these invading hordes. An ingenious landowner in the island, Mr. Richard Mattei, had noticed that when locusts are "upon

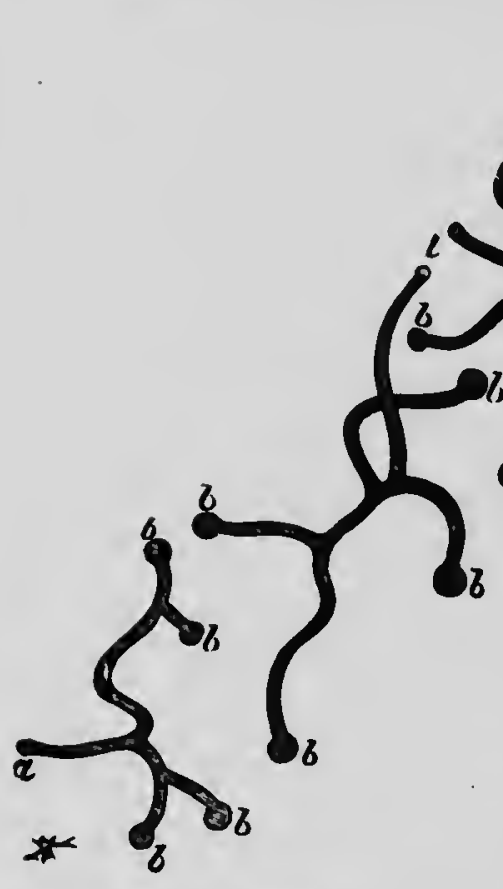

NO. 18.-THE RORBER'S CAVES : SECTIONS OF THE ENEMY'S RURROWS.

the march," about ten days after their hatching, they allow no obstacle in their course to stop them, but climb or crawl (like young eels up weirs) over every barrier that comes in their way. But he had also L.oticed that they could not get a foothold on a perfectly smooth surface; and he hit accordingly on a clever plan for checking their triumphant advance altogether. He induced the Government to bar their progress across country by erecting screens of canvas, set up on stakes, and topped by a broad band of that unpleasantly smooth and varnished fabric known to housewives as "American cloth." The American cloth was more than the locusts could stand: they preferred death to so vile an inven- 
tion. And this is how they meet their end with becoming fortitude. At the foot of the screens, deep pits are dug and lined with zinc. The locusts advance to the screens, which are laid right across their line of march, but being unable to climb over the polished cloth they fall into the pits. Thousands upon thousands thus tumble in masses on top of one another, and crush one another to death: the smooth zinc at the side effectually prevents them from climbing out again. In one year, the locusts were thus trapped in no less than 26,000 pits; the number of the killed was roughly estimated at a number which runs into twelve figures, say some $200,000,000,000$, or two hundred thousand millions. The cost of killing this gigantic host amounted only to $2 \mathrm{~s}$. a million, which is certainly not excessive. If we could conduct our Soudan campaigns on the same terms, I fear there would not be a native left alive in Africa at the end of a twelvemonth. The resources of civilisation would have civilised Baggaras and Matebeles into nonentity-which is sooner or later the usual course of our Imperial mission.

Another curious insect of the army-forming kind is that quaint little beast, the processional caterpillar of Southern Europe, an insect on which I have made continual observations for many seasons on the Riviera. The best-known species is the processional caterpillar of the pine tree; it lives in nests like those of wasps, surrounded with a sort of cobwebby silk covei. These nests may be seen by thousands on the trees in the Esterel in early 
spring: they are cut down and burned in vast quantities by the foresters, but no amount of burning ever seems to diminish their numbers. When they sally forth to feed or to bury themselves before assuming the chrysalis form, they march straight across country in a long line ; or if obstacles intervene, they curve round the base of trees or the edges of rocks in graceful undulations. Every procession has a recognised leader who heads the band : the rest follow after him in long Indian file, one after another, each holding on fast to the tail of the man in front of him. This at least is the only way in which I myself have ever seen them march. I find pictures in books of the caterpillars marching two or three abreast, or even in wedge-shaped triangular order: but after years of watching, I have never myself known them to go in any other way than single file, in a long sinuous line, one by one after the acknowledged leader.

If you break the line, the whole body at first seems paralysed for a moment; then slowly they begin to recover confidence and to meet the situation. The last man left at the end of the fore part of the train seems to pull or bite the tail of the man just in front of him, who in turn communicates with the next in front, and so on all along the line, till the news has been telegraphed right ahead to the leader. Then the leader halts, and all the rest halt behind him. Meanwhile, a similar telegraphic message has been sent post haste to the rear by the front caterpillar of the second half, or interrupted portion : he seems to halt, marking time, and so to 


\section{The Day OF THE Canker-Worm}

prevent the man just behind him from moving; this last by a backward shove similarly communicates the news of a breach to the insect at his tail ; and so on till both halves of the divided procession have come to a dead stand, awaiting developments. If you have only removed one caterpillar from the line to a little distance, he soon crawls back again into his place in the procession; in which case the nd insects on either side of him teiegraph forward and back the return of the lost member, and in a few minutes the cortige moves on again. But if you have hopelessly removed three or four caterpillars to a considerable distance, so that they cannot find their way back, the line waits for twenty minutes or so, to give them a fair chance, and then probably concluding that they have been eaten by birds or lizards, gives them up as lost, closes in again slowly, and resumes its march in a saddened and dispirited fashion.

I have experimented in many ways with these lines of caterpillars, and have always found that if only one insect was removed, the procession soon joined together again, either with him or without him. But if several were removed at various points, so as entirely to disorganise the whole line, the insects seemed to get puzzled and at last lost heart, curling round upon one another in a helpless muddle, and trying each to effect a junction with a leader. None but the original leader, however, seems qualitied to lead : a heaven-born king or elected president, I know not which, he is absolutely necessary to the safety of the line; remove him, and not 
an insect will stir a leg: no other of the line dare take the place of the duly constituted hierophant. Deprived of their chief, the caterpillars seem to be thrown into an agony of terror; each tries to shuffle off upon his equally unwilling neighbour the responsibility of going first. As a rule, this chaos ends by making them all roll up into a tangled ball and refuse to move either forward or backward; there they stop till they die, or are trodden under foot or eaten by birds, too timid to proceed without their proper general. I suspect that the ordinary pictures of lines three or four deep must be derived from such broken and disorganised processions; for I have never known a healthy and perfect line proceed in any other way than by single file order.

The last of these destructive insects with which I shall deal here is the dreaded army-worm, a terrible plague of American wheat-fields. The whole lifehistory of this dangerous wild beast is summed up for us in briet in No. I9, drawn also from materials supplied by Professor Riley, who worked harder at the investigation of these insect pests than any other entomologist in Europe or America. No. I in this illustration shows th harmless and innocentlooking eggs, quietly deposited by the mother moth on a blade of wheat as it grows. No. 2 gives us the larva just atched, and proceeding to make a meal on the farmer's young crop. Nos. $3,4,5$, and 6 show it groiving progressively fatter in the process, much to the detriment of the corn; while at 7 it is represented as turning into a pupa, and at 8,9 , and Io is seen as the perfect insect. This American 
army-worm commits terrible ravages in the western wheat-fields, and sometimes attacks whole districts at once like an invading battalion.

A totally different but still more interesting insect is known by the same name of army - worm in Southern Europe. It is the grub of a midge, and is not separately noticeable ; but its numbers make it conspicuous, and its curious habits have always attracted the attention both of naturalists and of farmers. The European armyworm, however, is not in any way a menace to agriculture ; it is merely noteworthy from the

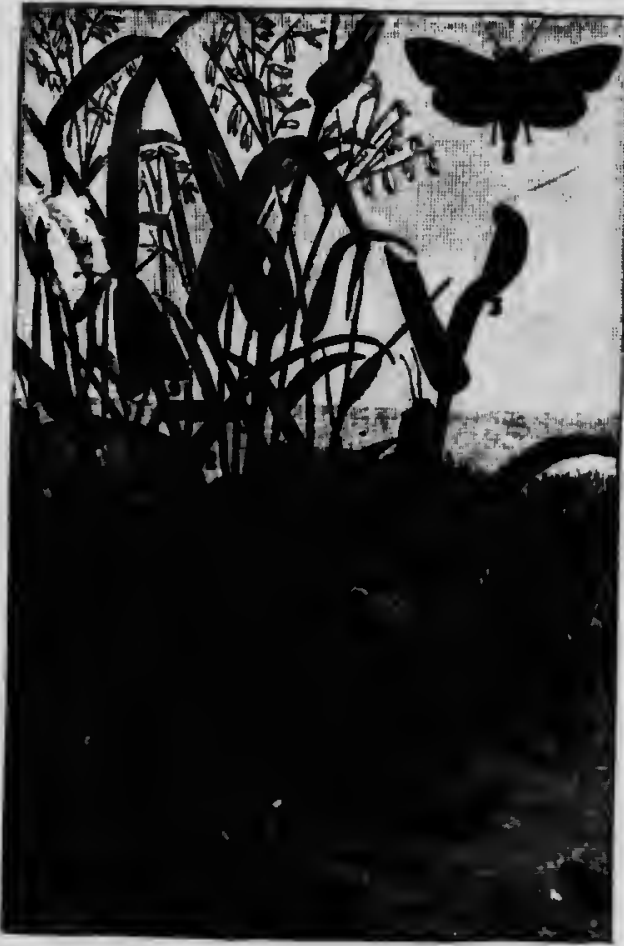

NO. 19.--LIFE-HISTORY OF THE ARMY-WORM. strangeness and weirdness of its processional habits. The adult midge is a small black fly, no bigger than a mosquito : it lays its numerous eggs among fallen and rotting leaves, which form the favourite food of its myriad larvæ. The eggs hatch out 
into little naked maggots, about a quarter of an inch long: the body is sticky and almost trans. parent, but the wee black head gives the tiny beasts a rather knowing expression, like insects of the world, quite at home in society. When the time arrives for the grubs to turn into chrysalides, thousands of families of them collect together among the fallen leaves so as to form a veritable army, which sets forth on a march across country in a serried phalanx, many feet in length, and crawling some sixty or seventy abreast in very irregular order. The line flows like a cataract over whatever comes in its way, the individual whitish grubs not being particular whether they crawl over one another or not; and as they wind in and out, around trunks of trees and gnarled roots or stems, they resemble nothing so much as a huge grey snake trailing slowly through the brushwood. The line seethes with life: it is a living stream, composed of translucent and viscid insects, so fluid and plastic in its mode of progression that you have to look close before you can convince yourself that it is really made up of individual maggots.

At last the army reaches a suitable place for undergoing its metamorphosis. Then instinct teaches it what to do. It halts by common consent, and the various grubs roll themselves up into a huge round ball, which seems for a time to be perfectly motionless. If you watch it long, however, you will soon begin to perceive that it is growing by degrees mysteriously smaller and 
sinaller. Can the grubs be eating one another up, like the Kilkenny cats? It looks as though the mass were disappearing slowly into thin air : only when the ball has begun to reach its last few layers do you get an inkling of the explanation of the mystery. The larva have chosen a nice soft spot in the deep black mould of the wood where they can easily bury themselves to undergo transformation. Those at the bottom of the ball first burrow into the ground, and are followed one by one by the others in succession. There they all assume the form of small mummy-like pupa; and after passing through their transformation underground, emerge at last as a vast and tangled swarm of small black midges, dancing in the sunlight with rhythmical motion. But though the European armyworm is really quite harmless, being a member of the rather innocuous or useful group of funguseating midges, the occasional appearance of the armies across a grassy path has always been a cause of superstitious terror to the peasants of the wild and tangled forest-lands which the creature frequents. Strange stories are told and believed about these innocent little grubs : their advent is a sign of impending war: they are the harbingers of invasion: they herald misfortune like comets and earthquakes : they even appear as portents of God's wrath before the occurrence of plague, famine, and pestilence. In New Orleans and other American towns exposed to yellow-fever, it is believed that a closely similar midge, the so-called "yellow-fever fly," accompanies the epidemics of that dreaded 
disease. But it is not improbable that the microbe of yellow-fever may really be spread by means of midges, so that in this respect the current belief of the New World rests perhaps upon a firmer basis than the antique superstition of the European
woodlands. 


\section{VIII}

\section{ARMOUR-PLATED AN'MALS}

$\mathrm{M}$

EN and monkeys, we all know, are imitative creatures.; but there are few departments of human life where man has been so entirely anticipated and at the same time surpassed by th:e lower animals as in the invention of armour. His cunningest devices of the mailed fist order were none of them original. If you examine a fine and fully-developed suite of plate-armour, in the iorm which it assumed at its highest zenith in the fifteenth century, you will find that the trunk and limbs were completely enclosed in a splendidlyfitting jointed case of iron plates, all exquisitely polished. The joints of these plates were arranged in the most ingenious manner so as to move freely over and under one another, without exposing any part of the body for a moment to the deadly chance of a sword-lunge or a lance-thrust. For example, the scale-like pieces which covered the shoulders were cleverly proterted at the ediges by fan-shaped projections, making it impossible for an enemy, however quick and deft, to get at the line of junction. The knee-caps, the shoes, the elbows, the gauntlets, all the minor parts of the caparison, were adınirably designed with great skill and care, so as 
to afford the utmost possible security to the wearer, and yet interfere as little as practicable with his freedom of movement. The suit, as a whole, was a triumphant product of the armourer's art. Yet if you look at the lobster's tail represented in No. 10, you will see at a glance that all these clever devices of man's imagining had been invented and patented long befrre by nature, and that the elaborate workmanship of the Plantagenet craftsmen, who cased knight and horse for the battlefield or the tournament in movable plaques of glistening metal, was but a poor imitation of the ineffable skill with which the unheeded crustaceans of the time protected every vulnerable portion of their bodies from the assaults and attacks of their submarine enemies. Gorget and visor and greaves and hauberk yield in perfection of fit and in absolute ease and freedom of action to the beautiful blue-black male of these rock-haunting paladins, or to the absolutely unassailable yet flexible corselets of the little burrowing South American armadillos.

It is interesting to notice, too, that just as in the case of the prickly plants and animals, so in the case of the armour-plated types, members of the most dissimilar and unrelated families, when circumstances happen to call for the development among them of mail-clad forms, produce on the whole extraordinarily analogous suits of panoply. They crop up everywhere. With the exception of the birds, which are never armour-plated (for one can hardly conceive of a flying ironclad), there is scarcely a single great group in the animal kingdom 
which does not number among its members one or more such cuirass-bearing species; and all the armoured types, from China to Peru, resemble one another in the most astonishing manner. It seems as if even nature could only find one central plan for coats of mail. Often, indeed, the resemblance is so close between unallied kinds that only a naturalist can perceive the deep underlying diver. sity in the midst of so mucl apparent similarity of external configuration. Just as a knight in armour and a horse in armour seem almost to belong to the same general group of articulated animals, so the armadillo absurdly resembles the tortoise, though one is a mammal and the other a reptile: while the similarity in type of the molluscan chiton (No. 12) to the common wood-louse (No. 5) is so close that it might deceive almost any one but the scientific observer.

As a good introduction to the tactics of the platearnoured class in general, I will begin with some brief account of the curious South African and Indian pangolins, or scaly ant-eaters. No. I exhibits a typical specimen of this quaint and belated race, the short-tailed pangolin, various modifications of which are found in most of the southern parts of the Dark Continent, from the West Coast and Mozambique to Zanzibar and Somaliland. The pangolins are also a good set of armour-bearers to begin upon, because, curiously enough, they stand about half-way in military tactics between our old friends the prickly hedgehog group, whose armour is offensive, and the 
turtle group, whose armour is defensive only. As we shall see a little later, the pangolins (like the White Knight in "Alice," witl his spiky armour) to some extent unite both these inethods of passive warfare : they are turtles when unrolled, but turn into incomplete hedgeliogs or porcupines if hard pressed by assailants.

A glance at the portrait of the short-tailed pan-

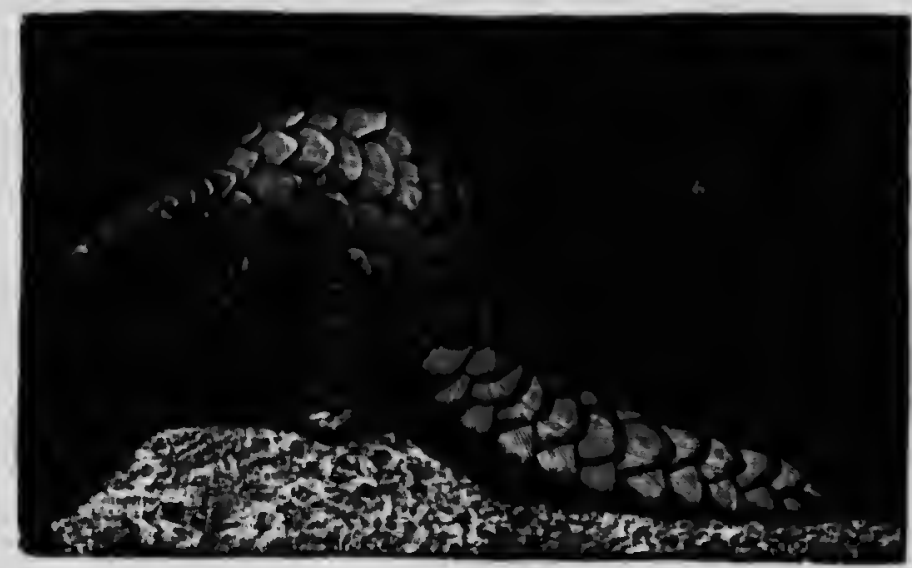

NO. 1. - TILE-SHAPED PLATE-ARMOUR: THE PANGOLIN.

golin in No. I will show you at once that this uncouth beast is clad from hend to tail in serried plates of defensive armour. He is about two feet long, and his head, I will admit, is remarkably small for his size; to say the truth, he does not posse'ss much brains to speak of, being a fairly dull and unintelligent animal. Central and South Africil have never been famous for evoking the 


\section{ARMOUR-PLATED ANIMALS}

higher intellectual qualities: most native races there, whether of Hottentots or beasts, are tolerably stupid. And the pangolin is, so to speak, the Bushnan anong South African mammals. The great peculiarity of the race, the point that has told for them in the struggle for existence, in spite of their stupidity, is the thickness of their skin, or rather of their solid, plate-like covering. This covering consists of large and sharp-edged scales, which overlap one another like the tiles on a house-another example of nature anticipating humanity, though to be sure in this catse fishes had already anticipated pangolins. The origin and character of the scales is in itself one of the queerest points about this very queer and uncanny animal. They are composed of hairs, which have grown sid by side and got gummed to one another, as it were, by an organic secretion : they are clotted curls, so to speak; in the very young cub, they are quite soft and light-coloured (like the prickles of new-born hedgehogs); but as the cub grows older, they become gradually harder and darker. In the full-grown pangolin they form a complete suit of jointed and plated armour, each plate being fastened at one end and free at the other, tile-wise, an arrangement which allows of great ease of movement. Part of the head, however, and the under portion of the body, are comparatively unarmed; and this gives rise to the habit of rolling up, which we have already observed in the case of the hedgehog and other prickly animals.

While the pangolin is walking, or rather shuffling 
along, for he is an ungraceful promenader, he is sufficiently protected from most enemies he is liable to meet on his nightly excursions-he is a nocturnal creature-by his scaly suit of impenetrable armour. But when any particular persistent foe tries to investigate him too closely, or to attack his one exposed and vulnerable point, the head, then the pangolin grows angry and forthwith adopts the hedgehog tactics. He rolls himself round into a ball (for which his arched back is admirably adapted), tucks his snout between his legs in front, and covers it from behind with his scaly tail, which is similarly tucked under him; and in this safe position, a living sphere, he sticks out his sharp scales at right angles, thus offering their unpleasantly pointed edge to the tender nose of his astonished adversary. Further inquiry is thus instantly obviated.

The resemblance to the hedgehog in all this is so striking that one might at first sight imagine the two creatures were closely related to one another. But this is not the case. The likeness is a likeness of habit only. The hedgehog is an insectivore, while the pangolin belongs to a very ancient and almost extinct group of animals, the toothless mammals or edentates, once widely spread over the surface of the earth, but now surviving only in a few outlying and unprogressive countries. It is ivell known to zoologists that South Africa, South America, Southern India, and Australia are (so far as their types of life are concerned) very belated and antiquated regions : they are not up to date; 
the animals which inhabit them are of those slc $w$. going kinds which once roamed over Europe, A: 1a, North Africa, and North America, but which have been long since replaced in the go-ahead continents by much more advanced and business-like creatures. Sloths, wombats, armadillos, ant-eaters, are types of the older and slower sort ; lions, tigers, deer, antelopes, monkeys, are types of the newer and more progressive fauna. Now, it is odd that out of the eight or ten species of pangolin known to men of science, half live in Central and Southern Africa, and the other half in India, Java, and Southern China. That is to say, they are scattered survivors of a kind once more widely spread, like the Finns and Lapps in Europe, the Eskimo in America, and the Samoyedes in Siberia, among human races.

At the risk of saying too much about one group alone among my armour-plated series, too, I must just find room to add here that the pangolin's second name of scaly ant-eater sufficiently describes his mode of life and staple diet. The little beasts are burrowing animals, and they have a very peculiar, long, worm-like tongue, which they can dart out and retract with lightning rapidity. The tongue is also covered with a sticky glutinous secretion; and this secretion serves the pangolin in good stead in earning its daily bread, or rath: $r$ its daily ants and termites. It is a curious sight to see them feeding. The animal makes an opening in the nests of the insects on which it preys, and darts out its extensilic tongue into the galleries of the interior. The aris or termites rush out, as is their wont when 
disturbed, to repel the invader. They are then caught and entangled in the sticky secretion, like flies on treacle-paper; as soon as the pangolin has secured as many as will make a mouthful, he withdraws his tongue or trap, and swallows his haul with great gusto. For this reason he has no need of teeth : but he grinds up his food internally afterwards, in a sort of gizzard-like stomach, assisted (as in the case of many birds) by occasional pebbles which act as millstones.

You may also perhaps observe that the pangolin's fore-feet have very long curved nails or claws, looking as if his mother had carelessly neglected to cut them in early infancy. These claws are excellently adapted for burrowing, and also for breaking into the nests of white ants and other tropical insects; but, on the other hand, they are so much bent under (like a hoe or pick) that, when the animal walks, he has to shamble along ungracefully on what ought to be their upper surface. This, however, does not greatly matter, as the pangolin is an infrequent and unobtrusive walker: he is generally engaged in private business underground; when he emerges into the open, it is mostly by night, in search of ants; for, being a slow and tardy creature, he naturally obeys the antique precept, "Go to the ant, thou sluggard." He shuffles along as best he may from nest to nest on the plain, in an awkward, slipshod fashion; and since he doubles himself up when attacked by more powerful animals, the clumsiness of his pace does not seriously harm 
him. Indeed, you wil! find that almost all armourclad or prickly creatures are slow of progress; being amply protected by their coat of mail or their suit of spiny quills, they have little need of the fleet foot of the hare or the slender limbs of the timid antelope.

A somewhat different type of pangolin, also from the Dark Continent, is represented in No. 2, which shows the portrait of the pale brown scaly ant-enter, a West African species. This creature, though it nests underground, is not so much

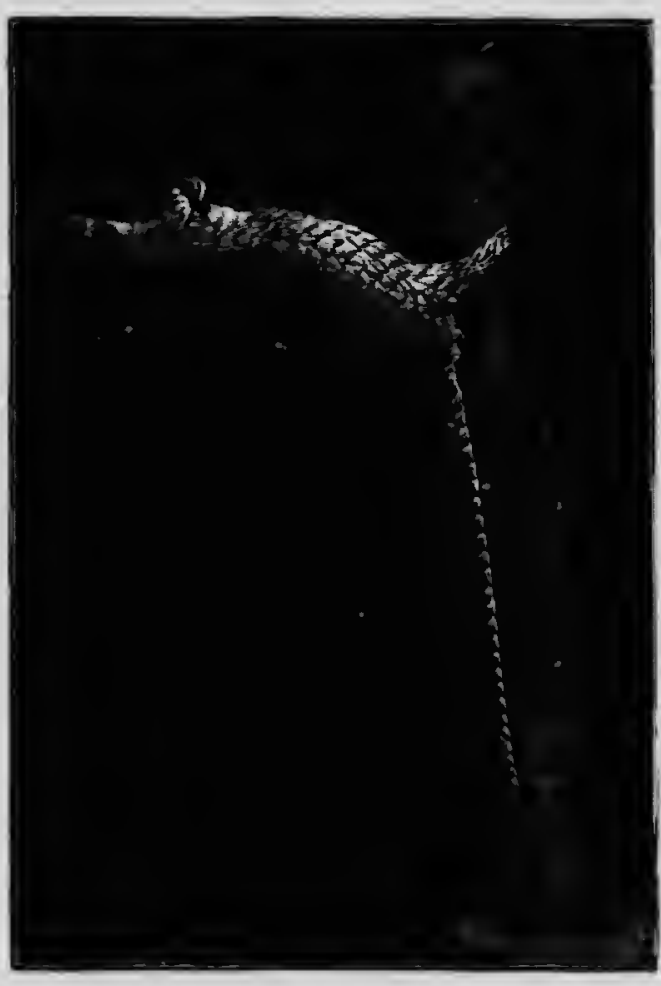
a burrower as

NO. 2. -THE TREE-HAUNTING PANGOI.IN.

a tree-climber: its scales each end in three sharp points, which give it a little more of the hedgehog character. Oddly enough, it has also one very hedgelıog-like trick, for it will roll itself up into a ball as it sits on the branch of a tree, 


\section{IN NATURE'S WORKSHOP}

and then fearlessly trundle itself over, trusting to the elasticity and solidity of its scales to break the fall for it. The pangolins, as a whole, indeed, have been well compared to "an animated spruce-fir cone, furnished with a head and legs." Nothing could better describe their quaint appearance.

Now, if we run right across the southern hemisphere from Africa to South America, we shall find once more an: ther curious group of armour-plated animals, belonging to the same great order as the scaly ant-eaters-the ancient and almost moribund order of edentates - and living like them upon ants and termites, but otherwise very different in many important poir.ts of structure. These are the comic little armadillos, a great many species of which are now known-odd-looking wee beasts whose general type is well exhibited by the photographic portrait of the three-banded armadillo in No. 3. This portrait, together with several others in the present chapter, has been taken from the excellent specimen in the British Museum, and I desire here to express my thanks to the authorities at South Kensington for the kind way in which they have permitted Mr. Enock and myself to overhaul and pose their treasures. But the oddest point of difference between the armadillos and the pangolins is the nature of their covering : in the pangolins, the plates of the armour are horny in texture, and consist of united or agglutinated hairs ; in the armadillo they are bony, being composed of bone-material deposited in the true skin in the shape of little shields, though each such shield is also 


\section{ARMOUR-Plated ANimals}

itself once more enclosed or overlaid by a horny plate, developed in the epidermis or outer scurfskin. In the particular instance I have chosen for our illustration-that of the quaint and dainty little three-banded armadillo-the coat of armour consists of several distinct portions. First, there is the cuirass or shoulder-shield, a sort of solid cape,

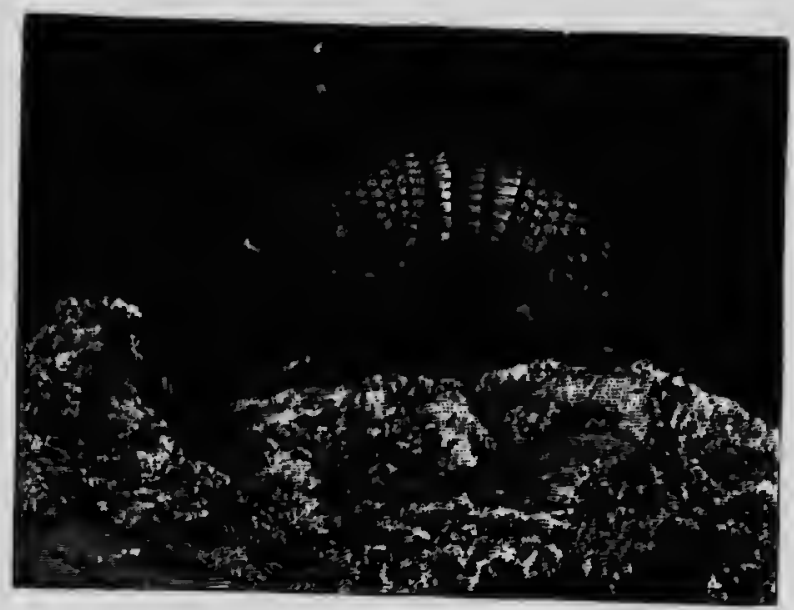

NO. 3- - SOLID CUIRASSES : THE THREE-BANDED ARMADIILO.

within which the fore legs can be completely withdrawn. Then there is the jointed central part, consisting of the three movable bands from which the animal takes its Christian name, so to speak, being distinguished from the rest of the armadillo family in general as the three-banded armadillo : this central part is girt in rows of plates with movable skin between them, and is extraordinarily 
Hexible and easy in its movements, the parts gliding beneath one another in the most admirable and workmanlike manner. Then comes the hind shield or body-armour, a sort of mantle for the flanks, with a notch in it to receive the tail; and this part serves to protect the hind legs as well as the whole of the back and digestive apparatus. Finally, a smaller set of plates protects the forehead and face, while another set covers the tail : so that only the under surface of the body is at any time exposed to the attacks of the enemies.

That is how the armadillo looks when it is abroad on its hunting expediuons and fears no foe; but let danger threaten, and, quick as thought, the little beast immediately clears the deck for action, as you see in No. 4, where it is shown preparing to receive cavalry. A dog or other inquisitive assailant has manifested a desire to investigate the armadillo : the armadillo wisely declines to be examined, and prefers to retire into the privacy of its internal consciousness. By a strong muscular contraction, it folds itself up bodily : the head and fore legs retreat behind the cuirass or cape; the hind legs tuck themselves away neatly in the recess of the bodyshield; and the armour-plated upper surface of the forehead and tail fill in the interspaces of the notched coat of mail, lying side by side in the crevice and completing the general globular form of the new position. When thus rolled up into a perfect globe, the armadillo is even better protected from attack than the hedgehog: for if a beast of prey tries to bite it, the smooth living ball glides 


\section{ARmour-plated Animals}

away unhurt, and leaves the baffled assailant openmouthed and wondering.

You will notice that in No. 3 the armadillc has very long claws on his fore-feet : especially is this the case with the middle toe, which is specialised as a burrowing instrument, and is useful in digging up the nests of white ants and other insects. The

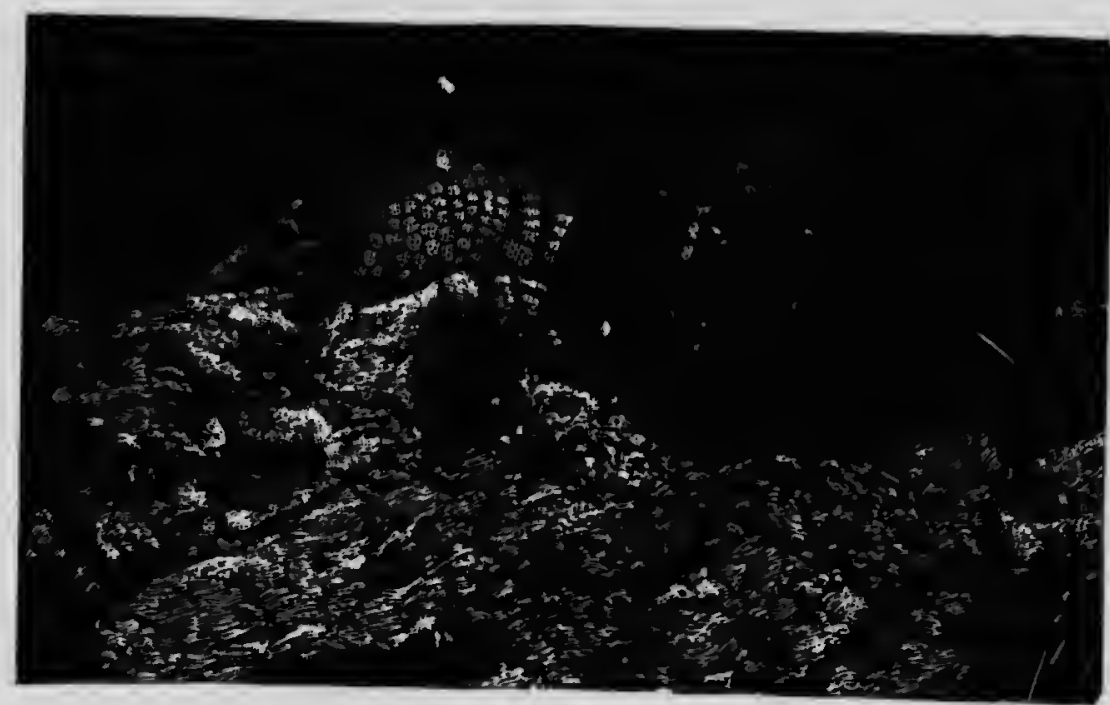

NO. 4. -AN FNEMY TIIREATENS: THE ARMADILIO RETIRES.

armadillos pass most of their life underground, and seldom venture out except in search of food or mates. But they are not for the most part nocturnal. All the existing kinds are comparatively 'mall-none of them longer than three feet-but many of their cousins in late geological times were much more formidable in size, and must have looked 


\section{IN NATURE'S WORKSHOP}

like gigantic turtles. An extinct species, known to science as the glyptodon, measured no less than eleven feet in length; while a still more closelyrelated type, the chlamydothere (I an: not responsible for these very learned words), was almost as formidable as its own name, for it rivalled in bulk our modern rhinoceroses. Such colossal creatures, clad in plate-armour to match, must have moved about like living terrestrial ironclads, and are sure to have been better respected than loved by most of their contemporaries.

It is to descend from the sublime to the ridiculous, I admit, to go straight from these huge South American fossil monsters to the common little wood-louse of our English copses (No. 5). Yet the resemblance of habit in that lurker undar stones to the burrowing beasts of the Argentine Pampas is so great that many prim speakers, disliking the strong Saxon flavour of its good old English name, habitually speak of our British wood-louse as "the armadillo" ; even science itself has sanctioned the usage in the slightly altered form of armadillidium. If you lift up a fallen $\log$ or mossy boulder in almost any English grove, it is ten to one that you will find crouched beneath it a curious little many-legged running beast, very smooth and shiny, who tries to avoid the light, and scampers away the moment the wood or stone which forms the roof is removed from his underground dwelling. Touch him with your finger, and he doubles himself up instantly into a shiny ball, as you see in No. 5 , being then protected from harm by his tough 
shell or armour-plated carapace. So smsooth and round is he, indeed, that he rolls away from your grasp, like a glized pill, and can hardly be picked up save with a little care. $\mathrm{He}$ is not an insect.

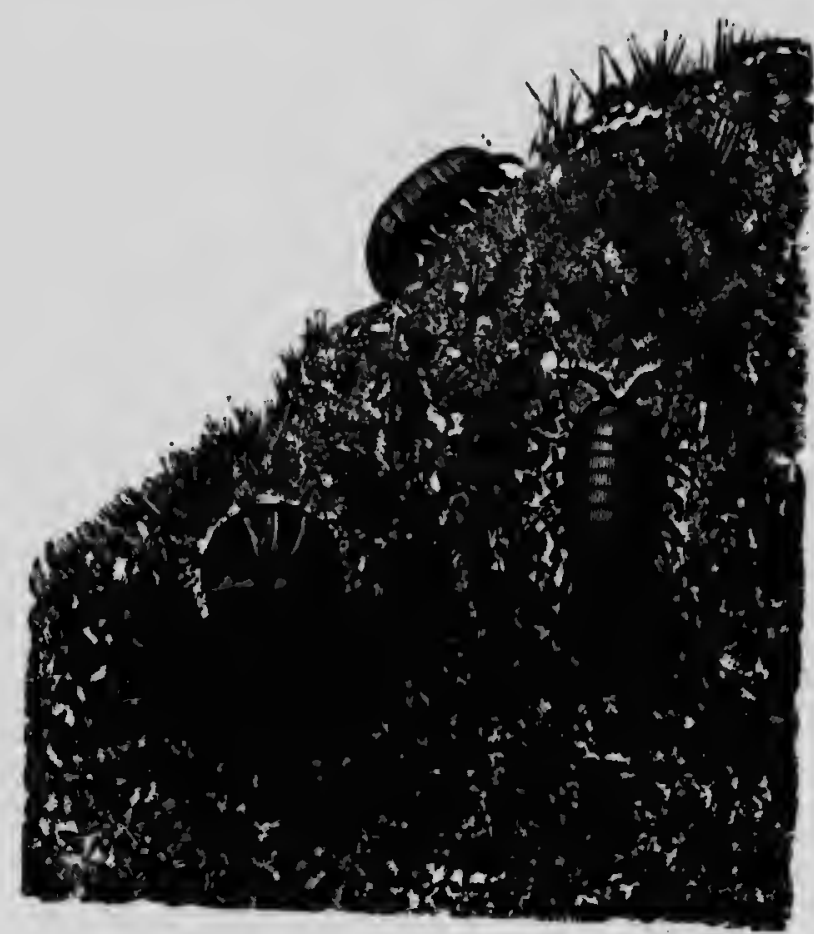

No. 5.-LIKE CAUSES, LIKE RESUlTS: THE
"ARMADILI.O" WOOD-LOUSE

The wood-lice are land-haunting crustaceans, remote relations of the crab and lobster, marine creatures which have stepped boldly on shore and adapted themselves to the habit of breathing air, though they still live in moist holes or crannies, 
among dark damp spots, hiding through the day, and prowling forth in search of food at right-time. They are vegetarians by conviction and habit, and live mainly on dead leaves, though they have also a decided fondness for living lettuces. But the curious thing about these little beasts is that, though they are crustaceans by descent, utterly unrelated, of course, to the armadillo or any other mammal, they have independently developed an almost identical mode of defence, and have learnt to tuck away their head and tail, and their many pairs of legs, within their smooth globular armour exactly in the same fashion as their South American prototype tucks his own belongings away within his hony cuirass. Even the muscular machinery for rolliag and unrolling the body and shell is absurdly similar in the larger beasts and the small ones. Many other examples of such globular armour-plated animals occur in various groups of lower t'pes; but I leave them to the ingenuity of the reader to discover.

Perhaps the most marvellous, however, of all the mail-coated animals are our good old friends, the common tortoises and turtles. We have been so long familiar with their shape, and with their extraordinary tunic of bone and horn, that we have long ago ceased even to wonder at them; but if we were shown a tortoise for the first time, and saw him withdraw his head and legs at a touch within the shelter of his shell, we should all exclaim, "What a surprising creature!" In order to understand the origin of the very complete defensive armour in the 
turtle group, we ought first to consider the bucklers and hauberks of the crocodiles and alligators, which, though much less perfect, lead up to and explain the turtle's panoply.

Crocodiles are, in essence, very big lizards, though they differ technically from the true lizards in some important points, but resemble them in outer shape and in most anatomicil peculiarities. But their chief and best-marked external feature is their loose coat of movable scaly inail, which stands to the solid, welded shell of the turtles much as the old linked chain-armour of the Norman conquerors stood to the developed plate-armour of the later Plintagenet period. Crocodiles have their backs, tails, and the under side of their bodies amply clefended by square horny shields, which inove freely against one another at the edges. In the more vulenerable parts, such as the back, however, the wily crocodile does not trust to the strength of these horny plates alone : he has developed beneath them a similar series of stout bony plaques, each of which is neatly and deftly jointed at the edge with the ones beside it. So perfect a safeguard in its own fashion is this double set of armour, horny and bony, that sportsmen will tell you the only sure way to kill a crocodile is to hit him in the eye : that is his one vulnerable spot, his heel of Achilles: everywhere else, a bullet glides off him harmlessly. $\mathrm{He}$ lolls in the water unconcerned and winks at his assailant.

Now, the turtle group are descendants, apparently, of some ancient ancestor who possessed a 
coat of movable armour extremely like the plated suit of the existing crocodiles and alligators. I venture to believe, even, that crocodiles and turtles are remote offshoots of the same original lizard-like stock, which has variously specialised itself for various walks of life under different conditions. All furtles and tortoises possess whit we call in common language a shell, though science-which always loves long words-prefers to describe it as a carapace. The shell is bony, and in almost ill instances is actually welded together into one with the backbone and ribs, so as to form a single inmovable dome-shaped suit of armour. If you look inside the dead shell, you will see the vertebrie like a chain running down the middle. There are usually two shells, one covering the upper part of the hody and one the lower; and in many species of tortoise-for their mame is legion, the family being a very large one-the head and legs can be entirely withdraw'n within the inargin of the carapace. In such as, just as in that of the armadillo, the gaps in the an mour are neatly filled up, for the exposed parts are covered on purpose with horny masks or aprons, which thus complete and round off the entire defensive mechanism. The bony dome itself is also covered with a skin or breastwork of horny shields, which form the externally visible portion of the shell, and are most interesting objects for examination, because they exhibit the origin and development of the whole suit of armour. For the visible horny shell consists in most species of quite distinct and unwelded plates, much as in the croco- 
dile, only that they are not separately movalile: while the true bony shell benenth them consists, on the contrary, of a single welded or united piece, which, however, "hen one comes to look it it closely, turns out to be compound-shows by its lines and channels that it was originally composed of distinct plates, like those of alligators. 'Thus th.

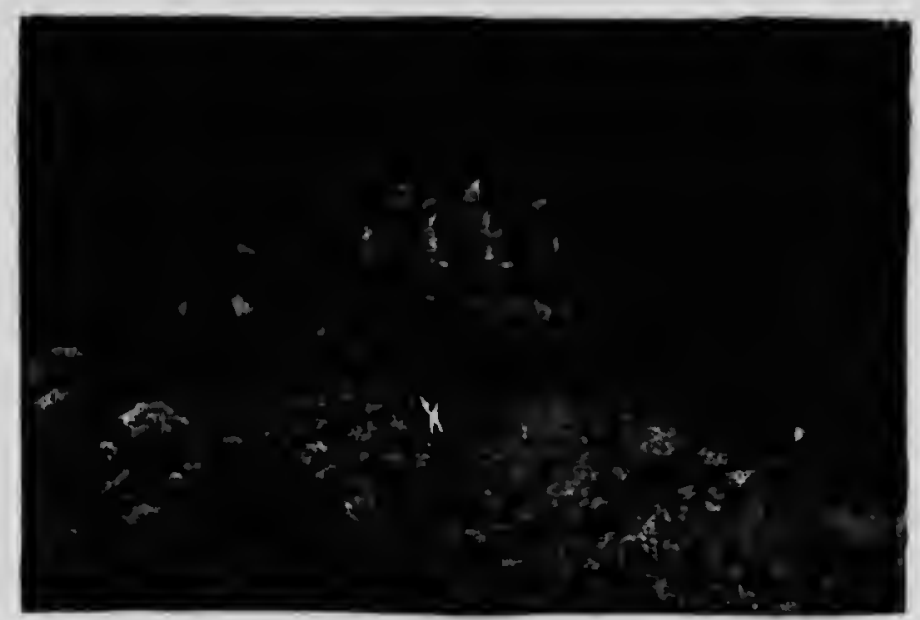

NO. 6. -A SOUTH AFRICAN TORTOISE WITII DISTINCT SCALFS.

turtles preserve for us in their own bodies an epitomised history of the course of their development.

I have selected for illustration here three species only among the many hundred kinds of the tortoise group now known to naturalists, in order to exhibit three successive stages in the gradual obliteration of the separate plates. No. 6 represents a landtortoise from South Africa, in which the plates 
are still almost as distinct as on a crocodile's back, though, of course, not movable. This is a very pretty dappled species, and the sculpture in relief on the separate shields or bosses which make up the shell is extremely elegant. No. 7 , on the other hand, is a tortoise from the Argentine: it displays much more flattened and obliterated shields, which

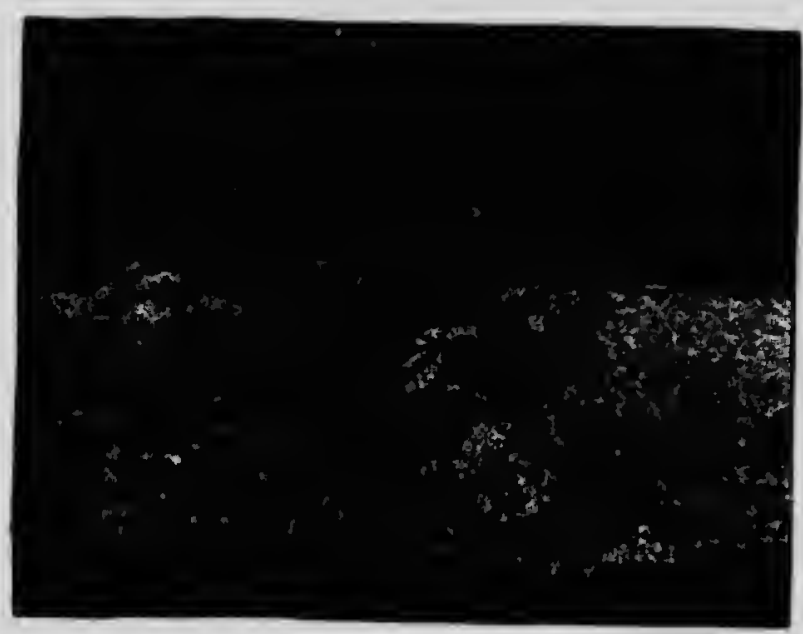

NO. 7.-A SOUTH AFRICAN TORTOISE : THE SCALES COALESCING.

have coalesced more perfectly, and do not nearly so well recall the original crocodile or alligator type. No. 8, again, is a good example of the basking mud-tortoises, in which the separateness of the plates has almost disappeared, so that the entire shell, both bony and horny, has practically coalesced into a single smooth and rounded dome. The particular specimen here figured comes from 
Port Essington (in these days of Imperial extension, I will be cosmopolitan at all hazards): but other mud-turtles, similar in this respect, are found in shallow waters almost all the world over. We have in these cases a little bit of the history of evolution among animals served up for us in detail: indeed, if you will go to the Natural History Museum

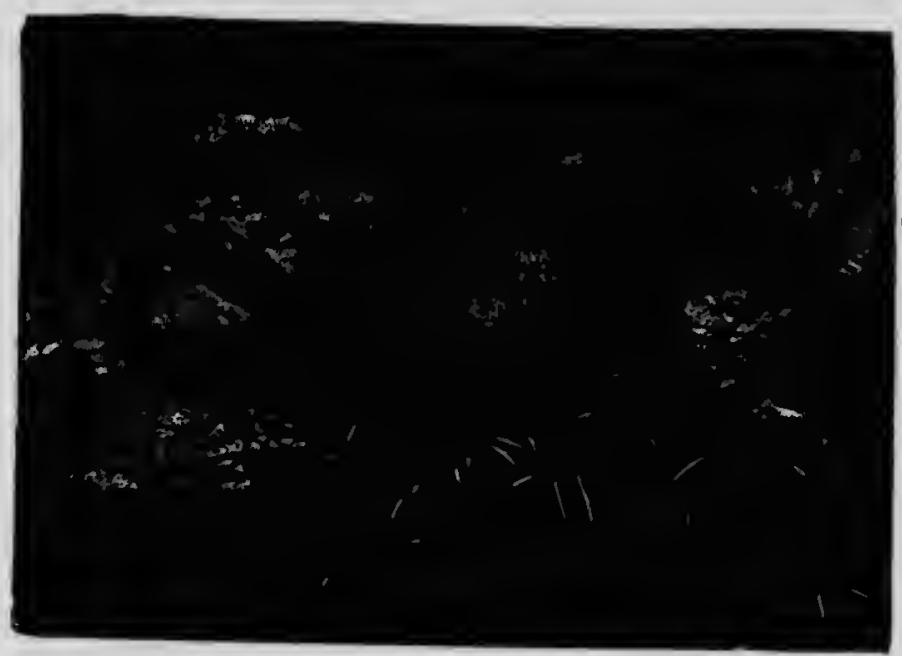

NO, 8. -A MUD-TORTOISE : THE SCALES ALMOST OHLITERATED.

at South Kensington and look carefully at all the crocodiles, alligators, tortoises, and turtles there on view-an endless group-you will soon come to the conclusion that here at least there are no "missing links," but that every stage in the Inng, slow evolution of the tortoise's shell from the separate alligator-like scales of its lizard ancestor has been fully preserved for us. Incidentally such a 
visit will also serve to suggest the unspeakable variety and diversity of nature : before you examine the cases in the reptile room, you will probably imagine that a few dozen types of crocodile and turtle are all that exist : after you have compared them in full, you will come away astonished at the number, the strangeness, and the exquisite adaptation of the many kinds displayed for you-which after all form but a portion of those existing in nature.

Let me give one probably unexpected instance of this curious adaptation to local conditions. The tortoises with humpy and bossy scales, more or less quaintly coloured (like the first here figured), are very conspicuous in museums : but in nature they are often quite hard to distinguish from their natural surroundings, even where they are plentiful and basking in the open; for they usually frequent rocky and pebbly spots, or else jungles of dry grass : and their humps and colours harmonise excellently with the shapes and hues of the objects about them. On the other hand, the smoothest forms are generally mud-tortoises, which sun themselves at their ease on logs in the water, or else lurk among soft mud, and under these circumstances their smoothness makes them less conspicuous to the few enemies whom even their solid coats do not enable them to set at defiance.

All the suits of armour with which I have hitherto been dealing are quite permanent: they cannot be taken off and put on again as readily as a mediæval knight-errant's casque and brigandine: 
indeed, since the turtle's coat and his backbone are, like the French Republic, "one and indivisible," he could no more divest himself of it with safety than you or I could change our skeletons;, or get a new skull to suit the fashion. But the next suit of armour of which I am going to speak has that further peculiarity that it is shed by its owner at periodical intervals-I mean the lobster's. Everybody knows, of course, that lobsters moult as much as canaries. They begin life as tiny tadpoles or larvæ, about half an inch long, in which stage they have grotesquely big goggle eyes, like the dwarf in a pantomime, and swim about freely on the surface of the water. You would never take them for lobsters at all at this point in their history: they have much more resemblanc' to the uncouth larva of beetles and mosquitoes than to their own demure and sedate parents. After several moults, however, and several perplexing alterations of form, like so many crustacean " quickchange artists," they arrive at last at the adult lobster condition. Adult, I say, because they have now attained their final form: but not full grown: they go on growing; and as the shell they wear fits them tightly all over, and is composed of a single piece, though much jointed, they have no alternative but to cast it off bodily from time to time, and develop a new one. When the lobster is still very young, he does this at fre n' in middle life, he does it once a year; but when he has grown old and thoroughly hardened, he changes his suit a good deal less frequently. At 
the moulting period he retires for a time into private life, and changes his suit, like a gentleman that he is, in a sequestered dressing-room, far from observers.

Oddly enough, however, he grow's before, not after, he casts his shell. That is to say, he lays by material for new cells and tissues inside his old coat, but he does not plim them out, so to speak -does not inflate them, if I may use a metaphor which will be clear to all cyclists. The raw stuff is there, but not the mere filling. At last, when he has got everything ready for the eventful change, he proceeds to endue himself in his new suit of armour. An entire soft shell grows round his limbs within the old hard one; then the lobster. withdraws himself, leg by leg, claw by claw, and swimmeret by swimmeret, from his disused coat, and steps out of his skin, a brand-new creature. Even the hard bits of the interior-the shelly walls at the base of the small legs-are shed with the rest; for the whole suit hangs together in one piece, the inner parts being, in reality, mere folds of the skin, doubled inward. The cast skeleton, when he has wriggled out of it, forms a perfect model of a lobster, in fact, and looks like a whole beast, till you discover that it is empty. The real lobster himself, on the other hand, after thus shuffling off his mortal coil, emerges upon the world a new and defenceless fleshly creature. It must feel odd for him to find himself suddenly deprived of his wonted mail. For in order to withdraw his big claws from the shed skeleton, and otherwise 
disengage himself from the suit he has outgrown, he has to become as soft as jelly: in which condition he pulls his limbs one by one through the narrow chink of the huge pincer-like claws in the most incredible fashion. As soon as the moult is complete, however, he begins to grow, or apparently grow, within the new and swelling skin, at a rate which might well astonish anybody but a mushroom. He absorbs water through the thin, jelly-like shell, and with it inflates the animal tissues; but before he takes off his o!d coat he has made himself a new one, perfect from head to tail, and waiting only to be hardened by a supply of lime, partly laid up in his body beforehand, and partly eaten for the purpose in the shape of other shells, which he greedily devours and digests in bulk at this stage of his existence. In a few days the new shell has acquired the consistency of $a$ leathern jerkin, and by the end of six weeks: once more become a perfect suit of solid pla armour.

Our own common lobster is, perhaps, the finest example now living on earth of the mail-coated animals : for he is a soldier and a member of a dominant type, like the mediæval barons in their iron panoply; not a mere defensively-armed noncombatant, like the armadillo and the tortoise, which skulk and hide themselves. Shielded by his impenetrable corslet of stony armour, provided with huge pinching claws which can crush a seashell like so much paper, and capable of attacking almost any foe he meets in his own element, your 
lobster is a magnate of the most ancient order. My illustration, No. 9, however, represents not this hidalgo of the seas, but a cousin of the family of somewhat inferior rank-the spiny lobster or sea-

cray fis h-w ho unites in his own person to a certain extent the tactics of the tortoise with those of the hedgehog. $\mathrm{He}$ is half armadillo, half porcupine in his mode of defence. His body is well covered by a stout corslet like that of the common English lobster, but instead of being smooth it is prickly or thorny like the shell of the Japanese devil-crab, whom I have had the honour of

No. 9. - THE SPINY LOBSTER, BOTH ARMOUR-PLATED AND PRICKLY. presenting to $\mathrm{my}$ readers in a previous chapter. And the reason why the spiny lobster needs this extra protection of spikes on his shell is pretty clear when you come to examine him closely. He has no great crushing 
nut-cracker claws like the powerful vices of the common lobster : his first pair of legs are scarcely bigger or more muscular than the others; as a man of war, he is not to be compared for a moment to his more familiar and highly developed

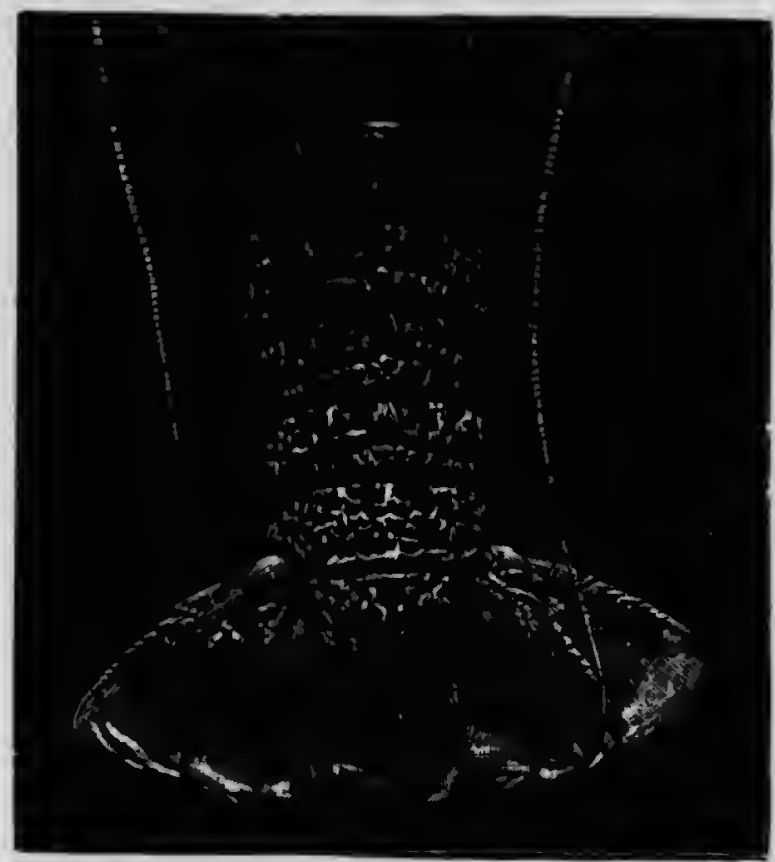

NU. IO.-THE SPINY LOBSTER'S TAIL, TO SHOW ARRANGEMENT OF PI.ATES.

relation. Therefore he makes up for it by spines on his back: he doubles the parts, as it were, of armadillo and hedgehog, so as to be safe either way. We have a spiny lobster of this type in our own British seas; but in order to meet the views of 
Colonial readers, Mr. Enock has here selected for illustration its New Zealand representative.

No. 10 is an enlarged view of this sea-crayfish's tail, intended to show its very close analogy to the joints of plate-armour exhibited in No. II. The

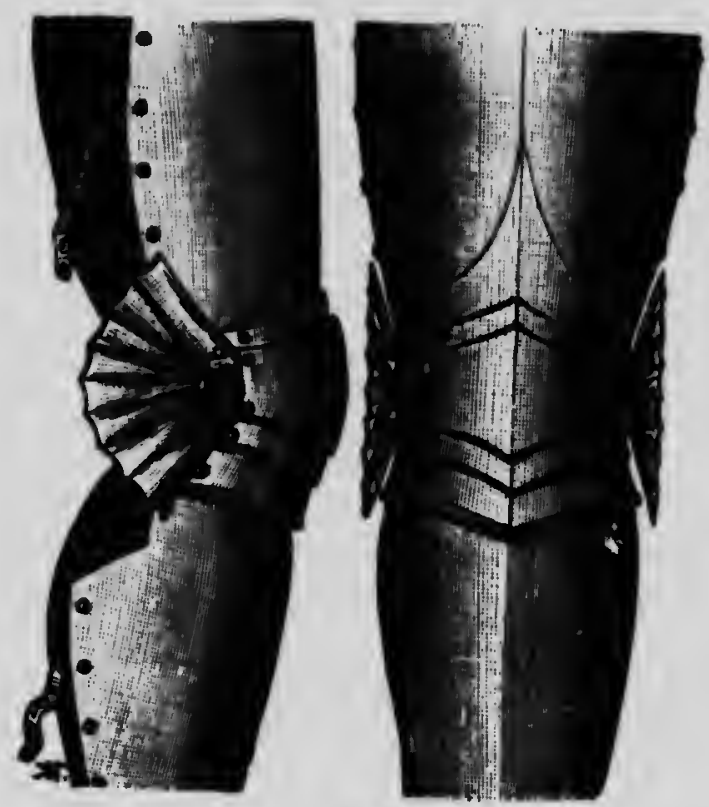

NO. II.-A KNIGHT'S PLATE-ARMOUR, FOR COMPARISON WITH THE LOBSTER'S.

resemblance is one of the best examples one could choose of the very close fashion in which art half unconsciously imitates nature, or nature half unconsciously foreshadows art. Compare it once more with the pangolin's tail and the armadillo's 
belts, and you will further observe how much nature also imitates and anticipates herself-how the same device to obtain the same result appears over and over again through all her handiwork.

The self-same lesson is very beautifully impressed upon us by the curious little marine creature delineated in No. 12. What is he? you wonder. Well, you know that most molluscs have either

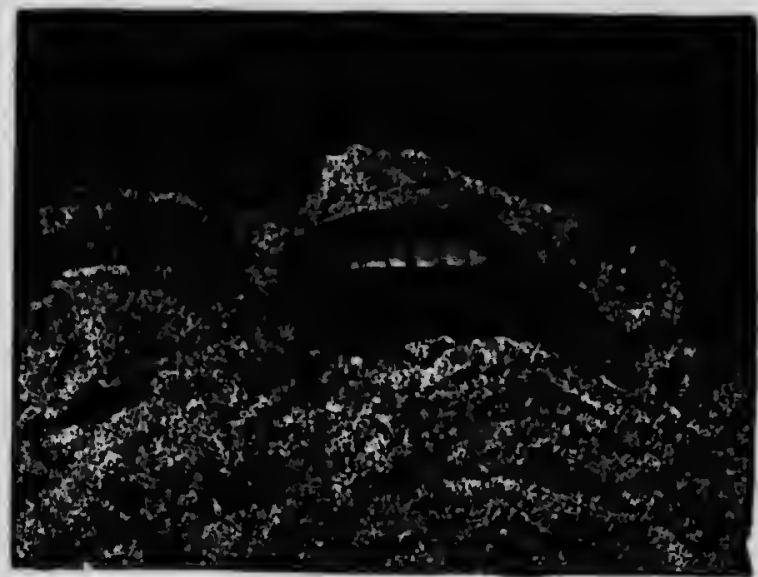

NO. 12.-A JOINTED AND ARMOURED MOLLUSC, THE CHITON.

two valve-like shells, familiar to everybody in the oyster, the mussel, the cockle, and the scallop-I choose examples whose nearness to "the great heart of the people" makes them sure of recognition-or else a single more or less spiral shell, as in the equally well-known cases of the whelk, the periwinkle, the garden snail, and the limpet. But you would hardly suspect this odd-looking creature, 
like a lobster's tail with the body omitted, of being also a mollusc. Nevertheless, it is one. Its name is chiton : and chiton is good Greek for a cloak or robe. The quaint beast in question derives his title from the eight flexible shell-plates which cover his back with a complete suit of armour, exactly analogous to so many which we have already examined. A few species of chiton inhabit our British seas; but it will give once more a faint idea of the vast variety of all these strange types if I add that, taking the round. world over, more than four hundred distinct kinds of these jointed molluscs have been described by naturalists.

I have chosen only a few among the larger or more conspicuous members of the great group of armour-plated animals, but many of them occur in other classes-too many for me even to enumerate roughly. Sometimes a whole vast alliance is armour-plated almost without exception-for example, the molluscs. The enormous majority of these are enclosed in very hard shells, like the oyster and cockle, sometimes reaching the size of the huge conch or giant clam, with three great tooth-like furrows, which is occasionally used as a receptacle for fountains, or as a font or holy-water basin in Continental churches. The big univalves, so often found as ornaments of cottage cabinets, show one equal hardness; and in many cases the mouth of the shell, the only exposed part, is closed by a solid door, known as an operculum, which the animal pulls in behind it, and keeps in place by 
means of a powerful muscle. In not a few instances, the hedgehog principle reinforces the turtle one: the shells are covered with hard spines or prickles. Some few molluscs, however, like the slugs, have found it pay to get rid of their shells : and here is curious to note a singular analogy with the gradual discarding of armour by human soldiers after the invention of firearms. For when the heavy plate-armour was superseded as a whole, the helmet and breast-plate, covering the most vulnerable and important parts, the head and heart, were still for a time retained, as by Cromwell's Ironsides. Now, just the same thing occurs in the transition from snails to slugs. True snails can retire altogether within their protective shells : intermediate types occur which have shells a little too small for them, so that they cannot hide in them; then come imperfect slugs, with small, shield-like shells carried on their backs-mere bucklers, just covering the heart and most vital organs; after that, we get slugs who have no visible external shell at all, but possess a hidden breast-plate under the "mantle" or flesh of the body, exactly as Cromwell himself is said to have worn concealed armour under his woollen jacket ; and, last of all, as in the big black slug, we find forms with no shell of any sort, open or buried, but at best only an imperfect relic in the shape of a few formless fragments of lime scattered about in the flesh of the mantle. Here, once more, as in the turtles, the various steps in the evolutionary history of a type have been fully preserved for us. 
The greater number of crustaceans, again, such as crabs and prawns, are also armour-plated, the armour being, of course, proportioned in thickness, as a rule, to the size of the animal. The great edible crab of our own coasts, too well known on the supper-table to call for illustration, is a most formidable beast, protected alike by his solid carapace and by the muscular strength of his powerful crushing claws, weapons hardly second to those of our friend the lobster. Among insects, too, there are several great groups of armour-plated kinds; for example, the beetles. The common stag-beetle of our own country is a fine instance of a mailed type ; some tropical kinds have shells as hard and as impenetrable as the crab's; many of them are also provided in addition with offensive weapons of no mean description. No. 13 exhibits a'simple typical case of a mailed water-beetle. The scorpions form another stout armoured class, with pincer claws as strong as those of the crabs and lobsters. I need enumerate no more; I must resist the temptation to describe at length the bony-pike of America, a true fish enclosed from head to tail in a complete and close-fitting mail of lozenge-shaped scales, enamelled and slimy, like a glistening suit of silvery armour; or the ungainly sturgeons, with their rows of bony plates protecting the sides; or that quaint creature the coffer-fish, like a living carved ivory box, incased in. a hard setting of six-sided plates, which form à curious mosaic pattern over its entire body. But I must draw a line somewhere. 


\section{Armour-plated Animals}

I will only suggest before I conclude that a good subject for a day's stroll through the Natural History Museum at South Kensington or any other great collection of zoological specimens would be

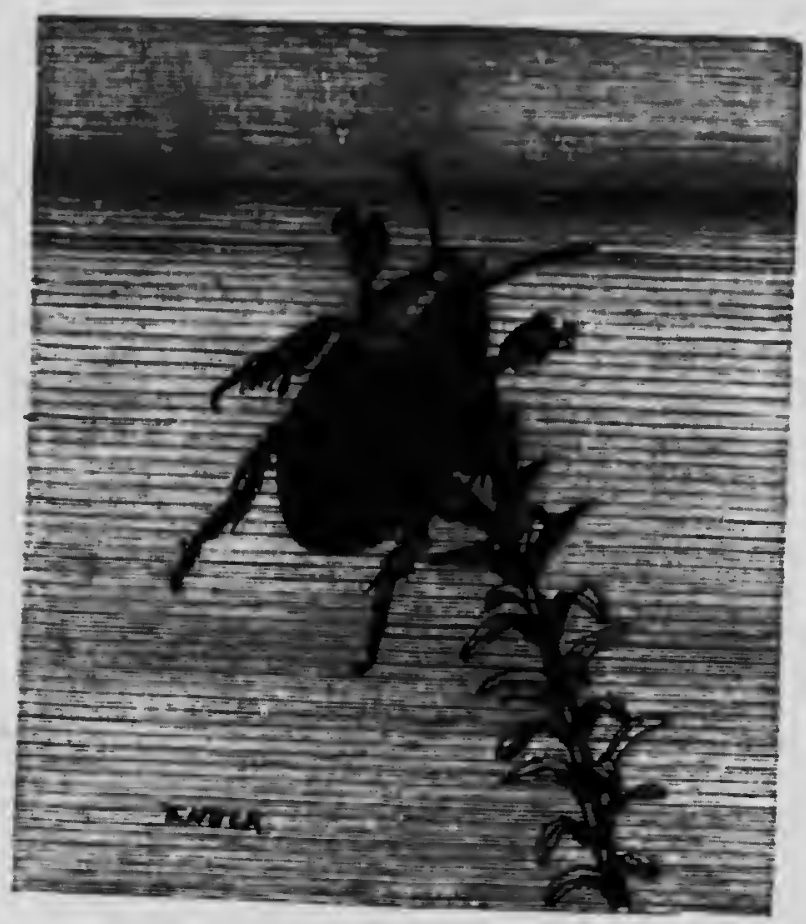

NO. 13.-A MAILED WATER-HEETLE.

the exa!nination and comparison of all such armoured creatures. Such a study would show, not only the similarity of the means employed for defence in various cases, but also the beautiful variety of ways in which the general plan of armour- 
240

\section{IN NATURE'S WORKSHOP}

plating is adapted in each instance to the particular needs of the different kinds, crawling, swimming, or walking, marine or terrestrial, powerful or feeble, provided with offensive arms or dependent wholly on their defensive covering. 



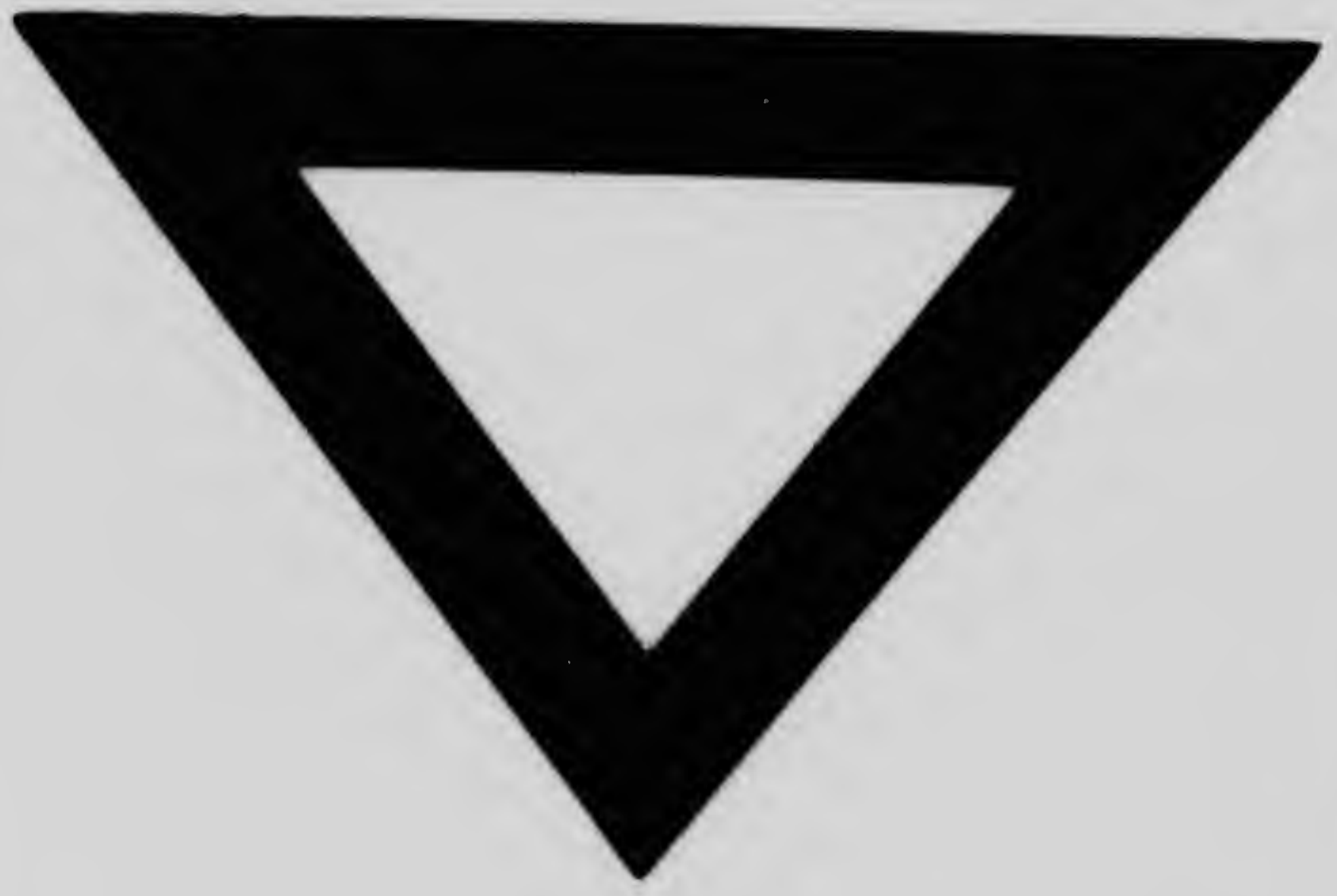

